\author{
Felipe Pinho
}

\title{
Reflexão histórico-epistemológica sobre os fundamentos epidemiológicos da Clínica Médica contemporânea
}

Tese apresentada à Faculdade de Medicina da Universidade de São Paulo para obtenção do título de Doutor em Ciências

Área de concentração: Medicina Preventiva

Orientador: Prof. Dr. José Ricardo de Carvalho Mesquita Ayres

São Paulo 
Dados Internacionais de Catalogação na Publicação (CIP)

Preparada pela Biblioteca da

Faculdade de Medicina da Universidade de São Paulo

\section{Creprodução autorizada pelo autor}

Pinho, Felipe

Reflexão histórico-epistemológica sobre os fundamentos epidemiológicos da Clínica

Médica contemporânea / Felipe Pinho. -- São Paulo, 2010.

Tese(doutorado)--Faculdade de Medicina da

Universidade de São Paulo.

Departamento de Medicina Preventiva.

Área de concentração: Medicina Preventiva.

Orientador: José Ricardo de Carvalho Mesquita Ayres.

Descritores: 1.Epidemiologia 2.História 3.Conhecimento 4.Humanismo

5.Aplicação de novas drogas em teste

USP/FM/SBD-005/10 


\section{Dedicatória:}

À Wanguinha, meu Ser. 
Agradecimento:

Agradeço ao Prof. José Ricardo Ayres, hermeneuta, cientista de inauditas metáforas, um médico exemplar. Agradeço ao Rico, por me acolher em sua morada. 


\section{Sumário}

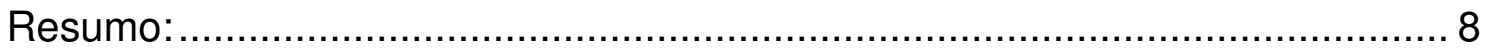

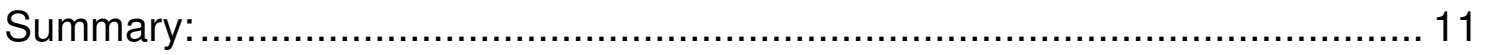

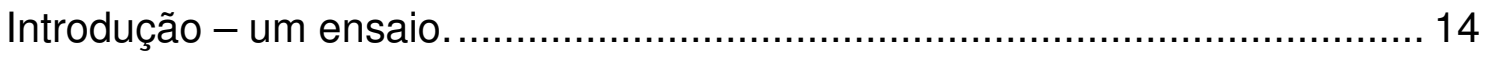

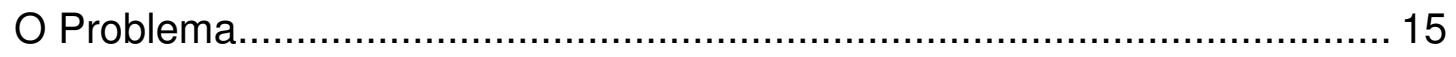

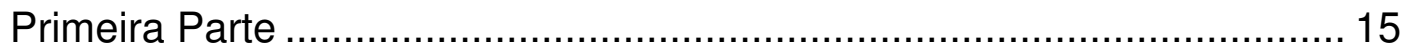

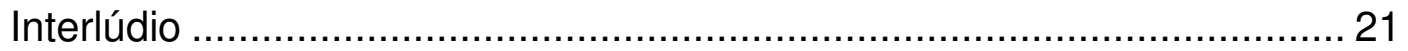

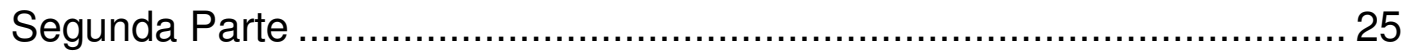

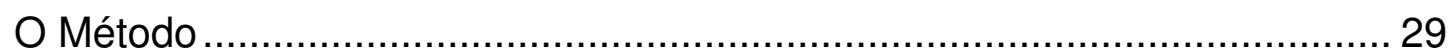

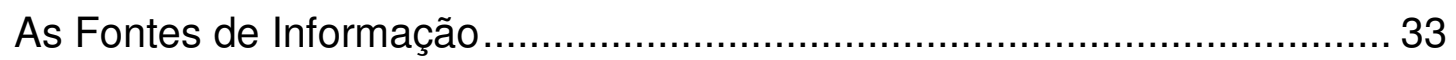

História Oficial do Registro de Novos Medicamentos nos Estados Unidos...... 40

Método histórico segundo Hayden White …………................................. 41

Modo de Elaboração do Enredo........................................................... 43

Modo de Argumentação ................................................................. 44

Modo de Implicação Ideológico ............................................................. 47

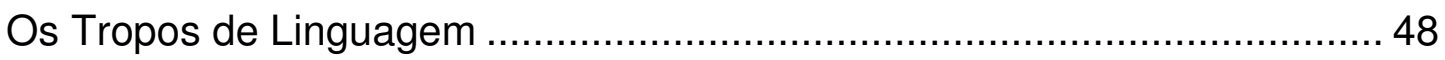

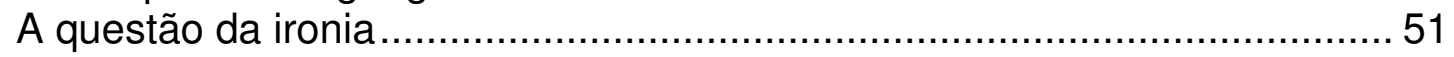

Food and Drug Administration (FDA) - A crônica de várias tragédias. ..........55

Uma arqueologia do registro de novos medicamentos nos Estados Unidos da

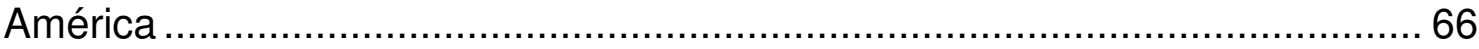

Parte I - Preâmbulo historiográfico......................................................... 67

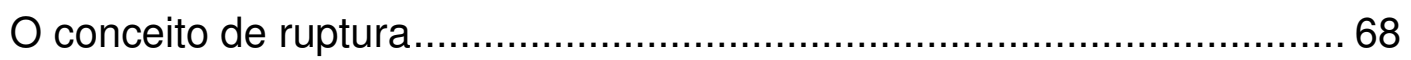

A concepção de história na obra de Michel Foucault ................................ 76

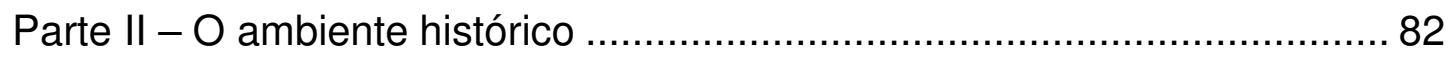

O ambiente econômico e político das décadas de sessenta e setenta. 83

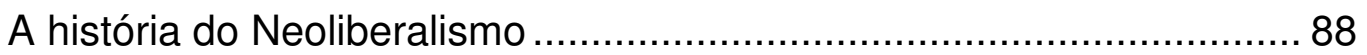

Uma nova forma de governar: Garantir as regras da concorrência.......96

Relação entre o neoliberalismo, o pragmatismo norte-americano, e o registro de novas drogas nos Estados Unidos. 
Relações entre as biografias dos principais personagens históricos 106

A crise econômica das décadas de sessenta e setenta - A primeira

crise.

Relação histórica entre o Utilitarismo e de Pragmatismo

Parte III - Ciência x Crises x Barreiras

A Emenda Keffauver-Harris - Continuação da primeira crise 134

O Caminho rumo à prova científica de eficácia e segurança de um tratamento médico - A segunda crise.

Relação entre FDA e Poder Legislativo - A terceira crise

A Racionalidade dos critérios científicos de eficácia

A questão de cientificidade dos dados. A prova de segurança e eficácia de uma nova droga.

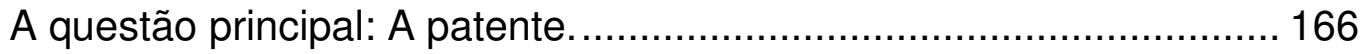

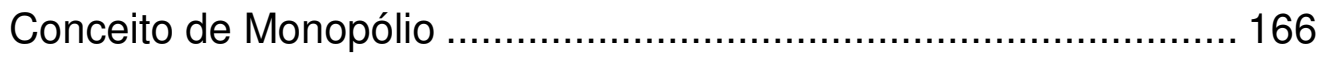

A Lei de patentes - A quarta crise ............................................... 170

A questão das margens de lucro ………………………........... 174

A questão do uso de marcas em produtos farmacêuticos ............. 176

A questão das modificações moleculares como inovações........... 177

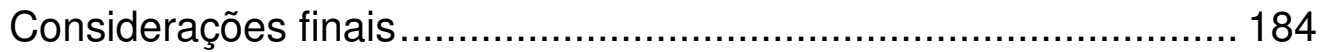

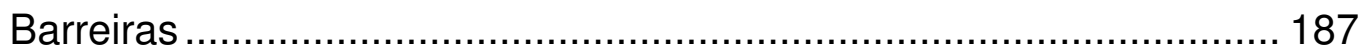

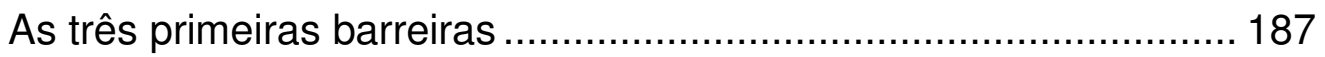

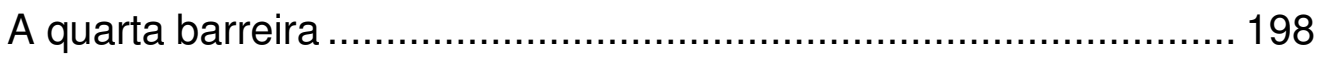

Considerações preliminares .................................................... 198

Relação entre Verdade e Poder ............................................... 200

Introdução à questão da crítica - Uma paródia............................. 207

Código de Regras (A Etiqueta do método). Como fazer para produzir o novo saber médico corretamente? ............................ 210

A legitimação da racionalidade científica do novo saber médico . 215

Considerações Finais - Outros desdobramentos .............................. 222

Parte IV - A questão da humanização da medicina ................................... 225 
Introdução

Análise Crítica sobre os textos de saúde coletiva que tratam da relação entre o método científico e a prática médica.

Relação método científico e prática clínica................................... 229

A questão da humanização e sua relação com o objeto desse trabalho 243

A história do humanismo 245

Caminhos a percorrer. 251

Bibliografia. 259 


\section{Resumo:}

A medicina clínica apresentou a partir dos anos 1960 uma certa inflexão em seus mecanismos internos de produzir conhecimento, assim como em sua forma de aplicar esses conhecimentos na prática. A principal diferença em relação ao passado foi que, a partir dessa época, os problemas de natureza clínica, como diagnóstico diferencial, terapêutica e estimativa de prognóstico, passaram a ser processados predominantemente por instrumentos de análise padronizados e, principalmente, submetidos ao escrutínio de uma razão empírico-matemática. A entidade "paciente" deixou de ser um ente emissor de sintomas e sinais que são processados por um médico, para ser uma nova entidade em que esses signos, previamente estabelecidos e validados pelos estudos clínicos e pela razão matemática, são encaixados pelos médicos nas manifestações dos pacientes. Na mesma época em que esse processo ocorreu o mundo ocidental vivia um período de crise que se caracterizava por um baixo crescimento econômico e por um questionamento por parte da sociedade dos princípios normativos, tanto éticos quanto morais, que regiam sua forma de viver.

Nos Estados Unidos, a partir de 1962 passou a ser uma exigência legal que toda droga nova, antes de ser comercializada, deveria provar, através de testes científicos, que ela tinha eficácia terapêutica, que de fato funcionava na patologia que se propunha tratar. A metodologia para promover esse tipo de demonstração foi construída a partir dessa exigência. As regras de prova científica de eficácia foram construídas a partir dessa demanda legal, e são chamadas genericamente de "Epidemiologia Clínica". Vários agentes participaram ativamente do processo de definição das regras do método científico que foram então, a partir dessa data, implementadas e sedimentadas. Destacam-se nesse debate, a comunidade acadêmica, a sociedade civil, os economistas, os advogados e juizes, os agentes do governo, e, finalmente, a indústria farmacêutica. Essa última assumiu uma posição de destaque, secretariando, e, de certa forma impondo uma agenda de discussão. O motivo por detrás dessa atitude foi uma profunda crise de legitimidade das regras de operação do negócio farmacêutico em dois de seus principais componentes: os 
desenvolvimentos tecnológicos, responsáveis pelas inovações na área terapêutica, e, a garantia de um mercado historicamente monopolístico, legitimada pela instituição secular da lei de patentes. Ambos esses institutos passaram, nas décadas de 1960 e 1970, por um conturbado processo de rediscussão de seus fundamentos. Defende-se que essa função de secretariar a discussão por parte da indústria farmacêutica teve um papel de destaque na construção das regras de cientificidade que passaram, desde então, a regular o ato médico.

A implementação, aceitação e sedimentação como princípio normativo de prova de verdade dessa metodologia científica, sobretudo na comunidade médica, ocorreu de uma forma muito particular. Discute-se nesse trabalho a história dessa implementação sob duas perspectivas: a história oficial conforme descrita pelo Departamento de História do Food and Drug Administration (FDA, Agência Federal Norte-americana), e, alternativamente, através de uma análise dos discursos proferidos por personagens que direta e efetivamente participaram dessa discussão. Médicos, farmacologistas, advogados, legisladores, economistas, profissionais da indústria farmacêutica e agentes do governo emitiram e discutiram opiniões, e estas foram registradas e publicadas. Esse material compõe a matéria prima em cima da qual trabalha-se no sentido de compor uma história que acaba por ter alguns pontos diferenciais em relação à versão oficial. Em torno desses pontos procura-se produzir um discurso sobre a relação entre ciência, lei, economia, e, prática médica.

A dimensão científica dessa história se mistura intensamente com outros aspectos igualmente importantes como: debates legislativos, interesses econômicos de segmentos privados, papel do Estado na regulação econômica, confiabilidade na neutralidade das publicações científicas, participação do mundo acadêmico no desenvolvimento tecnológico de um país, etc... Defendese que a fusão desses discursos em um formato consensual construiu uma situação em que a referida dimensão técnico-científica passou a ter uma importância relativamente maior do que as outras como instrumento de legitimação da verdade em medicina na sociedade, e que esse fato teve algumas importantes conseqüências práticas, destacando-se: um processo 
progressivo de desumanização do atendimento médico e a produção de um sistema de barreiras que dificultam o exercício de uma critica eficiente e positiva por parte dos profissionais ligados à pratica médica.

Por último, em torno do conceito de humanismo, abordado particularmente dentro da tradição filosófica ocidental, discute-se o quanto essa hipertrofia da dimensão técnica e suas conseqüências práticas, podem ser questionadas em seus fundamentos epistemológicos visando a reconstrução de uma prática médica mais humana e emancipadora.

\section{Descritores:}

- Epidemiologia

- História

- Conhecimento

- Humanismo

- Aplicação de novas drogas em teste 


\section{Summary:}

Since 1960 Clinical Medicine suffered a kind of inflection in its internal mechanisms of producing theoretical knowledge, as well as in the way that this knowledge is applied in practical life. The most important difference in relation to the past was that problems of clinical nature like, differential diagnosis, therapeutical decisions, and prognosis estimation, started to be predominantly processed by standardized analytical instruments, and most important, they were always previously submitted to an empirical-mathematical reasoning. Individual patients were no longer a being that reported signs and symptoms that were processed by a physician, they started to be a new entity in which these signs, previously established and validated by clinical studies have to be necessarily engrafted by the physicians in patient's manifestations. At the same time that this process occurred, western world was living an important critical period, characterized by a very slow economic growth, and by a reevaluation of its ethical and moral values.

After 1962, in the United States, it became obligatory to prove, through empirical scientific evidence that a new drug was effective, before marketing and sales authorization was issued to a company who wanted to launch the drug. The scientific method designed to prove efficacy of a drug was actually developed after this legal demand. This method is called generically "Clinical Epidemiology". Several actors participated in the discussion of the rules of this method. Medical Schools, government representatives, pharmaceutical industry can be cited; the latter played a very special role, since it acted as a secretary of the whole process. The reason behind this was that, at those times, the two major pillars of the pharmaceutical business, innovation capacity and patent law, were being severely criticized, and proposals for changing the way this things were being conducted in American society were about to become a reality. We defend the position that the attitude of the pharmaceutical business representatives, were crucial for the establishment of the scientific rules that were considered consensual, and that these rules, for many reasons, started to 
be the paradigm of medical reasoning and individual decision in medical problems.

Implementation, acceptance, and maintenance of this new clinical scientific method that was born after the legal demand for prove of efficacy of a new drug, particularly in medical community, occurred in a very particular way. We discuss the history of this process under two separate perspectives: the official history, as described by History Department of the Food and Drug Administration, and alternatively, through an analysis of the speeches of persons who actually participated directly in this discussion. Physicians, pharmacologists, lawyers, legislators, economists, pharmaceutical industry representatives, government members and politicians, all these groups, emitted their opinions and these were registered and published. This is the row material that was used to composite a new story of the whole process, and the result of this work is somehow different from the official history reported before.

The scientific dimension of this story is mixed up with other important aspects like: legislative debates, private economical interests, the role of the State in regulating the economy, academic participation in decisions related to economic growth of a country, etc...We try to prove that the intersection of all these interests in a consensual framework built up a situation in which the previously referred technical-scientific dimension started to have a relatively bigger importance in relation to the other aspects as an instrument to legitimate what is truth (or what is false) in clinical medicine, to the whole body of the society. This fact brought two important practical consequences: a progressive reduction in other human aspects of clinical medicine apart from technology, and, the development of a system of barriers that jeopardize the possibility of a critical attitude towards the scientific method from those who practice medicine.

Around the concept of humanism, studied particularly inside western philosophical tradition, we discuss how much this so called hypertrophy of the technical-scientific dimension and its practical consequences can be scrutinized and questioned in its epistemological foundations in order to rebuild a new medicine more human and critical. 


\section{Descriptors:}

- Epidemiology

- History

- Knowledge

- Humanism

- Investigational new drug application 
Introdução - um ensaio. 


\section{O Problema}

\section{Primeira Parte}

Esse estudo procura se situar em dois planos gerais. O primeiro se refere ao problema da produção do conhecimento em medicina. É o plano epistemológico. O segundo, às formas de utilização desse conhecimento na prática clínica. Esses são planos gerais, muito gerais. Sua descrição nesse momento visa apenas situar o espaço conceitual onde tentei permanecer ancorado. As dificuldades de recortar esses planos de uma forma que a significação prática dos resultados finais pudesse ser percebida, e até, eventualmente, útil no futuro, foram enormes. Realmente, devo confessar, meus objetivos iniciais tinham uma dimensão enciclopédica muito além da minha capacidade. Resigno-me por imaginar que esse deve ser um equívoco relativamente comum no meio acadêmico. À medida que fui tomando consciência dessa dificuldade, procurei produzir redefinições do espaço teórico onde deveria trabalhar, mas nunca, de fato, abandonei a pretensão inicial de tentar apontar sugestões de análise e crítica que se aproximassem desses dois planos conceituais.

Retrospectivamente, observo que a primeira grande dificuldade que enfrentei na busca de um melhor recorte da área de trabalho foi encontrar uma relação mais clara entre esses dois planos. Deveriam ser considerados como lineares e contínuos (um acontecendo em conseqüência do outro)? Ou eles deveriam ser vistos como paralelos e em planos diferentes (ambos acontecendo de forma independente, mas que, aos poucos, vão se articulando)? Ou ainda deveriam ser considerados como perpendiculares e definindo um espaço tridimensional com diferentes compartimentos (discursos independentes que se cruzam, eventualmente se modificam e seguem adiante em sua independência)? Gastei bastante tempo tentando pensar qual seria a melhor abordagem para que a relação entre esses dois planos fosse provada, e, para que essa prova resultasse em algum tipo de reflexão crítica sobre as práticas médicas contemporâneas. 
A primeira conclusão desse primeiro desafio foi, em si, para mim, um objeto a ser descrito. Conclui que não faria muita diferença o formato que escolhesse. Talvez a escolha viesse a tornar o material mais fácil, ou agradável de se ler. Talvez até pudesse deixar as conclusões mais claras, mas, sempre, em qualquer escolha, haveria um preço a pagar, e, esse preço teria que ser balanceado em relação à ambição inicial. $E$ aqui começo a me embrenhar na descrição das minhas escolhas, citando um trecho do livro "Mínima Moralia" (Adorno, 2008), do pensador alemão Theodor W. Adorno. O texto chama-se "Atrás do espelho", e diz assim: "Uma regra de segurança do escritor: examinar cada texto, cada peça, cada sentença para ver se o tema central se apresenta com suficiente nitidez. Aquele que busca exprimir algo está tão envolvido nisso que se deixa levar sem refletir. Fica-se "em pensamento" demasiado rente à intenção e esquece-se de dizer o que se quer dizer". Para não correr esse risco, e, antes mesmo de continuar essa introdução, vou descrever minhas conclusões situado nos dois planos que descrevi previamente, e, tentar articular essas conclusões:

Plano epistemológico: A metodologia científica contemporânea que é empregada na clínica, e que será descrita como Epidemiologia Clínica, foi desenvolvida ao longo das décadas de 1960 e 1970. Houve vários determinantes, ou patrocinadores ideológicos desse desenvolvimento. Procurei nesse trabalho destacar que um dos mais importantes desses determinantes teve relação com as necessidades da indústria farmacêutica de se reinventar em seus métodos e procedimentos com o objetivo de manter a essência mesma da operação do seu negócio que circula em torno de um monopólio legitimado pelo instituto da lei de patentes.

Plano da prática clínica: Essa metodologia, originalmente, deveria servir apenas como instrumento técnico para garantir que os produtos farmacêuticos fossem registrados oficialmente, e pudessem ser livremente comercializados. Entretanto, a confluência e articulação de múltiplos interesses e objetivos da sociedade, (além das necessidades da indústria farmacêutica que já citei, somam-se os interesses da academia médica, dos legisladores e da própria 
população) construíram condições de possibilidade para que o método passasse a se constituir como um verdadeiro paradigma de cientificidade da prática médica, interferindo na forma como os médicos raciocinam e tomam decisões em relação a seus pacientes. $\mathrm{Na}$ forma como cuidam dos seus pacientes. Defendo que essa nova forma de pensar e de agir, de alguma forma, e junto com outros determinantes que não abordei em profundidade, ajudaram na construção de uma prática médica predominantemente instrumental e desumanizada.

Articulação dos planos: Apesar da desumanização progressiva da prática médica, importantes e inquestionáveis desenvolvimentos científicos ocorreram nas áreas diagnósticas e terapêuticas ao longo desse período. Defendo que a compreensão do processo histórico de como a metodologia científica médica contemporânea se sedimentou em toda sociedade (e não apenas no meio da comunidade médica), pode ajudar a compreender os frutos positivos dessa metodologia, não apenas no que subtrai da necessária vertente humana da medicina, mas também do que pode adicionar a essa vertente. Parto da expectativa, talvez um pouco ingênua, de que há um ponto em comum entre 0 excesso de tecnologia aplicada à prática médica e a necessidade de um resgate da dimensão propriamente humana da medicina. Proponho, finalmente, que esse ponto em comum seja usado para o início de um diálogo construtivo que desemboque numa prática médica mais humana.

Volto agora ao primeiro problema. Para chegar a essas conclusões optei predominantemente pela terceira opção topológica, ou seja, julguei que seria mais apropriado ver os dois planos como perpendiculares, ou para ser mais preciso, como se entrecruzando com alguma angulação, não necessariamente de noventa graus, mas que, desse cruzamento, novas perspectivas de abordagem surgissem.

Acontece que, para que essas novas perspectivas pudessem ser ao menos levadas em consideração, julguei que seria adequado um método comparativo. Decidi então abordar, ainda que em graus diferentes de profundidade, a relação entre os dois planos tanto do ponto de vista já descrito acima, quanto 
de uma forma linear. Essa perspectiva será mais bem descrita na segunda parte dessa introdução, quando abordarei as questões de método de análise e redação que mais me inquietaram, e, que, deveriam ser previamente esclarecidas. A idéia não é contrapor uma abordagem à outra para ver qual é a melhor. A idéia é, colocar em evidência que, por detrás de uma história, seja ela contada de que forma for, sempre e necessariamente há uma tomada de posição, há uma implicação ideológica, há uma necessidade estética do autor que tem que ser atendida. A minha escolha essencial, entretanto, aquela que congrega a maior parte da argumentação e dos dados, foi a do entrecruzamento espacial dos planos epistemológicos e o da prática clínica.

A segunda grande dificuldade que enfrentei foi o instrumento de análise que iria empreender para promover essa tentativa de entrecruzamento de planos. Havia basicamente duas opções: 1) uma análise epistemológica formal dos procedimentos da Epidemiologia Clínica (refiro-me a discussões de temas como: problemas dos critérios, definição dos processos dedutivos e indutivos, teoria da justificação, circularidade epistêmica, empirismo, realismo, etc...), 2) uma análise histórico-epistemológica. O processo de decisão para essa escolha foi relativamente fácil. Logo percebi que a quantidade de discursos envolvidos em cada um dos planos individualmente era tão grande, e já havia tantas reflexões sobre eles, que, somente uma abordagem histórica poderia, talvez, se aproximar de uma tentativa de articulação que fosse coerente. Além disso, uma análise usando exclusivamente os instrumentos epistemológicos formais seria sempre incompleta, uma vez que uma análise histórica já, em si, engloba, ainda que parcialmente, essa discussão. Optei pelo método históricoepistemológico, e usei como matéria prima do estudo em sua dimensão temporal a história do registro de novas drogas nos Estados Unidos.

O motivo para a escolha da trajetória do registro de novas drogas foi a leitura de textos sobre o assunto (esses textos que serão descritos na última parte dessa introdução), e que me revelaram aspectos que considerei particularmente interessantes. Nesse espaço destaco o fato de que até 1962 não havia nenhuma obrigatoriedade de prova de eficácia para o registro e comercialização de um produto farmacêutico. A terapêutica médica, numa 
época em que já tínhamos a penicilina e muitos outros antibióticos, os corticosteróides, a maioria dos antihistmínicos, alguns anti-hipertensivos, e muitas outras classes de drogas que ainda hoje utilizamos largamente, era legitimada apenas com dados biológicos e estudos clínicos não comparativos, abertos e com pouquíssimo controle. A partir dessa data, uma prova científica de eficácia passou a ser uma exigência legal; entretanto, dez anos depois, no início da década de 1970, ainda se discutia como, afinal, se deveria proceder para provar que uma droga era eficaz e segura. Nesse mesmo período, várias crises que serão descritas ao longo do texto (econômica, científica, institucional e de legitimidade do sistema de patentes), ameaçavam a operação do negócio farmacêutico em sua essência mesma, no que é lhe é mais importante. Defendo que a construção do aparelho metodológico da Epidemiologia Clínica surgiu, e principalmente se sedimentou, como paradigma de racionalidade em resposta a essas crises. Defendo também, como disse nos parágrafos anteriores, que, apesar da origem da Epidemiologia Clínica ter tido vários focos (indústria, academia, instância legislativa), o papel da indústria farmacêutica merece um destaque especial. Por esse motivo escolhi esse assunto como ponto de articulação histórica do meu discurso.

A terceira dificuldade foi a escolha dos temas em cada um dos planos em torno do quais deveria articular a discussão de uma forma que permitisse sua intercessão. Talvez essa tenha sido a escolha mais difícil. Não tanto pelo lado do plano epistemológico. Intuitivamente, alguns pontos eram aqui claros para mim. Estes eram resultantes tanto de experiência pessoal, como profissional médico, quanto de leituras prévias sobre o tema. Ambos os caminhos apontavam para as técnicas relacionadas com a Epidemiologia Clínica, com seus métodos, regras e resultados, como um excelente índice, ou tema, em torno do qual procuraria articular um discurso. Realmente esse não era um problema. Sabia que o método da Epidemiologia Clínica se aplicava mais a decisões de registro e legitimação jurídica do que para decisões médicas individuais. Sabia que fora em torno dessa legitimação que esse método se amalgamou. Sabia também que, apesar do método ser amplamente utilizado como instrumento de decisão (ainda que não necessariamente de forma consciente), tanto na prática clínica, quanto nas discussões acadêmicas, e de 
se constituir como verdadeiro paradigma de racionalidade da medicina científica contemporânea, não era muito difícil conseguir adeptos, ou interlocutores, que concordassem com os limites estreitos que eu procurava, propositalmente e insistentemente, estabelecer para a abrangência e utilidade prática real da Epidemiologia Clínica, no contexto da prática clínica individual.

Constatar esse fato era extremamente interessante e intelectualmente instigante por dois motivos. Primeiramente por intuir que uma análise formal do método proposto pela Epidemiologia Clínica, concluiria, se bem sucedida, com os argumentos que praticamente o senso comum já sabia, ou seja, que os resultados do método não deveriam ser aplicados diretamente, e sem múltiplas considerações prévias, ao indivíduo. Em segundo lugar, a constatação de que, apesar da maioria dos interlocutores, sobretudo os médicos, saberem muito bem disso, eles não sabiam que na prática, ao decidir por um tratamento de uma doença em um paciente individual, freqüentemente usam a racionalidade proveniente desse método. E mais, apesar desses interlocutores saberem que o método não se aplica, e, apesar de não terem consciência que na realidade eles aplicam o método no nível individual, eles não sabem, em geral, que há poderosas barreiras que os impedem de construir um processo crítico esclarecedor sobre todo esse processo. $\mathrm{O}$ atual método de decisão médica foi como que naturalizado.

Portanto, ter a Epidemiologia Clinica como alvo no plano epistemológico não se constituía como um problema. O problema era como transformar essa crítica num efetivo e útil instrumento de crítica. Recorri então à literatura sobre o assunto. Sobretudo àquela produzida pela área de Saúde Pública no Brasil. Não foi preciso uma revisão muito extensa para perceber que a competente e abundante crítica existente publicada sobre o método da Epidemiologia Clínica aponta em uma direção convergente: que os resultados práticos desse método conduziram a uma prática médica predominantemente instrumental, e, a um crescente processo de desumanização dessa prática.

Essa conclusão, que voluntariamente assumo os riscos e eventuais penalidades por estar equivocada, simplesmente me paralisou por um bom 
tempo. O que é isso afinal? O que é humanização ou desumanização da medicina? É possível existir uma medicina desumanizada? É possível aumentar ou diminuir a quantidade de humanidade da prática médica? No que essa discussão ajuda para se construir uma crítica libertadora da forma como se pratica a medicina? O que isso poderia ter a ver com a produção de conhecimento em medicina? Como isso ajudaria o médico praticante a se questionar sobre sua atividade cotidiana? Como fazer com que esse questionamento transforme essa prática na direção de melhorá-la? Confesso que durante muito tempo achei que essa abordagem atrapalhava mais do que ajudava, mas, ao mesmo tempo achava que faltava à maioria dessa crítica, uma auto-reflexão sobre o que exatamente ela queria dizer com humanização. Esses problemas pareciam não ter uma solução que me satisfizesse.

\section{Interlúdio}

Acontece que tenho um vício. Um vício terrível: gosto de textos curtos de prosa filosófica. Gosto de ensaios (essa introdução se propõe mais como um ensaio do que como um texto acadêmico tradicional). Amo em particular um autor, 0 fundador do estilo, o célebre e imortal filósofo francês do Século XVI, Michel de Montaigne. Apesar de Montaigne ter escrito muitos textos interessantíssimos sobre a medicina da sua época (ele era portador de litíase renal e detestava os clínicos de sua época pela falta de racionalidade de suas propostas terapêuticas, venerando, contudo, os cirurgiões, por sua resolutividade e efetividade) (Montaigne, 2001 a, b, c). Apesar disso, não é por esse motivo que o cito nessa introdução. Montaigne é considerado por alguns autores como um dos mais importantes fundadores do conceito de humanismo no ocidente moderno. Há quem diga que foi ele quem primeiro usou a palavra "humanização" na língua francesa (Tournon, 2004). Seja isso verdade ou não, há em Montaigne reflexões muito interessantes sobre a humanização que ele definia fundamentalmente como a separação, que era a essência do seu pensamento, entre o "mundo da teologia" e o "mundo dos humanos". Montaigne defendia, em contraposição à tradição escolástica, que ele odiava e combatia, que os homens deveriam direcionar suas vidas em função de suas próprias observações e dos resultados práticos dessas observações. A própria 
teologia, a própria questão da existência de Deus, deveria ser analisada nessa perspectiva (algo como: Deus existe simplesmente porque nos é útil como seres humanos). Era uma espécie de individualismo cético, mas, isso não significava em absoluto que seu individualismo não considerava os outros seres humanos. Na verdade, o texto em que introduz o conceito de humanização, traz também em sua estrutura a noção contrária de desumanização. Esse texto se encontra no Livro I da obra maior do autor, Ensaios, e trata do horror que representava para a humanidade a perseguição que sofriam os judeus portugueses na sua época.

Trazia essa leitura de forma absolutamente paralela ao problema que descrevi acima. Não pretendia chegar ao extremo de apelar para o pensamento de Montaigne para falar de epistemologia médica, mas, como todos sabem, a mente humana opera com sistemas muito pouco previsíveis. Um dia, sem muito esperar nem programar, bastante desanimado e desmotivado por não estar conseguindo um tema que ligasse de forma coerente, pelo menos no meu ponto de vista e nas minhas necessidades estéticas, o plano da crítica epistemológica com o plano da prática médica, não tendo encontrado ajuda nem nas conversas com os colegas médicos, nem com a leitura de alguns textos sobre o assunto, tive uma espécie de descoberta pessoal, uma espécie de revelação: descobri que sou um humanista! Descobri também que o que se chama de humanismo, assim como suas derivadas como humanização e desumanização, podem, na realidade, ter vários significados. Podem ter universos de representação conceitual bastante diferentes, assim como conseqüências práticas, do ponto de vista de interpretação dos fatos da vida, também, bastante diferentes. Juntei essas percepções com a suspeita de que os textos que havia lido sobre o assunto não tinham avançado suficientemente na discussão sobre o que exatamente é humanismo, o que exatamente seria uma prática que se propõe a humanizar a medicina, e, decidi usar uma análise sobre o conceito de humanismo como uma forma de promover 0 entrecruzamento dos planos que me interessavam.

É importante destacar aqui, e de forma veemente, que não se trata de um processo de descredenciamento das práticas ou mesmo das teorias sobre 
humanização em medicina. Não é nesse plano que quero me situar. Não me julgo credenciado, nem ética nem tecnicamente, para realizar uma crítica dessa natureza. Minhas habilidades como ser humano estão, infelizmente, longe de qualquer tipo de excelência individual (no sentido grego do termo: areté) (Mora, 2004) (Aristóteles, 1884 b) que me façam sequer pensar que tenho o direito de julgar essa tradição. Admiro profundamente todas as tentativas de engajamento em um programa de humanização da prática médica, e acredito que toda realização nessa área, por menor e mais marginal que seja, deve ser louvada e comemorada. Seus executores devem ser reconhecidos e premiados. O plano que me situo é outro.

O plano que quero povoar quando falo em humanismo é o plano da filosofia. Trata-se de uma incursão um pouco arrogante, um pouco ambiciosa demais, de, ao identificar a questão do "humano" no discurso sobre as práticas médicas, isolar esse termo, e tentar, através de uma abordagem um pouco diferente do que vi, ou consegui entender, redefinir ou repensar a questão da dimensão humana da medicina, ou para ser mais específico, da prática médica. Optei por insistir na discussão em torno do humanismo apenas para tentar facilitar a articulação discursiva, e também para limitar 0 universo de referências de natureza filosófica que deveria utilizar. A verdade é que, nesse plano em que me aventurei navegar, o que se chama genericamente de humanismo, cada autor adota uma particularidade conceitual, define seu humanismo. Vejamos por exemplo Aristóteles. Como afinal o estagirita definia Ser Humano? Bem, pode-se dizer em um resumo bastante incompleto e misturando um pouco sua metafísica com sua ética, que, para ele, um ser humano era um corpo feito de carne e osso (causa material), que tinha uma forma, que era a sua alma (ou essência, ou Ser), que no caso específico do Ser Humano era a razão (causa formal), e que tendia a algum lugar, que era a busca do bem ou da felicidade (causa final), e que, para atingir essa tendência natural de busca da felicidade, tinha que exercitar suas virtudes (causa eficiente). As virtudes eram, não só para Aristóteles como também para Platão (e para a maioria da tradição grega): a coragem, a temperança, a justiça e sabedoria (ou inteligência) prática (Aristóteles, 1984 a). Para cada uma dessas 
palavras que citei em torno da noção de ser humano de Aristóteles, de causa até sabedoria, há toda uma literatura, há séculos de discussão, há inúmeras conseqüências práticas. A simples noção de justiça já foi responsável por guerras atrozes e por realizações de inestimável valor para a humanidade. Tentar falar de todas essas questões é uma tarefa que, tenho a impressão, ninguém jamais sequer imaginou ser capaz. Nem Hegel. Muito menos eu, um homem infame.

Meu objetivo ao trazer a discussão do humano em medicina para esse nível, não é, repito, dizer que há uma forma certa e outra errada de conceituar o humanismo. Isso simplesmente não existe. O que quero é, através dessa discussão, suscitar a reflexão sobre a importância transcendental (não consigo pensar em outro adjetivo menos comprometedor) da dimensão humana da prática médica. Alertar, como muitos já estão fazendo, e de forma muito interessante e competente, que, a super utilização da técnica e da ciência na medicina contemporânea, está fazendo com que essa dimensão humana seja tratada como menos importante como secundária (Ayres, 2004). A técnica está engolindo o homem no que ele tem de mais nobre, usando novamente a autoridade do Aristóteles, na sua essência (Ser), que é a sua capacidade de racionalizar, de criticar, de refletir, de se fazer perguntas, de produzir críticas. Talvez até de pensar que o próprio conceito de ser humano pode ser superado, de que outras propostas, talvez mais profundas e eficazes, de se pensar o homem em sua relação com o mundo possam pragmaticamente ter efeitos mais poderosos para se atingir o que se quer: aumentar a valência humana da prática médica.

O uso da história da racionalidade que conduziu ao processo legal do registro de novas drogas nos Estados Unidos, deve ser vista em sua verdadeira dimensão, e há duas abordagens que podem ser feitas para isso. A primeira, evidente por si só, é de que esse é apenas um pequeno recorte, uma aproximação tangencial ao problema da relação entre humanismo e medicina. A segunda, tão importante quanto, mas que, para se evitar interpretações equivocadas deve ser descrita, é a de que ao escolher esse assunto, e, sobretudo, ao escolher o método como o abordei, tinha como objetivo, produzir 
uma contribuição positiva, uma contribuição que transcendesse a ironia, e que agregasse de fato uma nova perspectiva a uma discussão mais aprofundada sobre as relações entre a prática médica e o humanismo. Na minha visão pessoal, e espero conseguir demonstrar isso, houve uma estreita relação, que não apenas temporal, entre as necessidades da indústria farmacêutica de se adequar a um novo marco regulatório, a construção de uma nova forma de se produzir verdade em medicina, e, a hipertrofia da dimensão técnico-científica da medicina contemporânea. Também na minha perspectiva pessoal essa é a melhor forma de contar a história como ela realmente aconteceu, ou está acontecendo.

\section{Segunda Parte}

Uma outra leitura, esta (como veremos adiante, na parte das fontes de informação), não totalmente paralela, também dificultava minha capacidade de tentar articular os planos. Refiro-me à obra de Michel Foucault, em particular a sua magistral análise histórica sobre as origens das ciências humanas em "As Palavras e as Coisas" (Foucault, 1966) e suas reflexões críticas sobre a noção do que a tradição intelectual marxista chama de "Teoria do Estado" (Foucault, 1975; 2005 b; 2005 c; 2005 d; 2008). Não há como descrever todo esse complexo pensamento nesse espaço. Entretanto, à guisa de tentar explicar como busquei articular os dois planos discursivos nos quais ancorei meus objetivos, vale a pena alguns comentários gerais a esse respeito. Foucault questiona duramente a idéia de que se deve construir ou circular em torno de uma Teoria do Estado. Segundo ele, partir desse conceito como uma espécie de universal, como os marxistas (e mesmo muitos liberais) fazem, dificulta a compreensão de como o Poder de fato se manifesta em uma sociedade. Para ele, o núcleo da discussão deve se deslocar em direção ao próprio Poder, sobre como o Poder se exerce no seio de uma comunidade, sobre como o Poder circula e se articula de forma discursiva nos vários agentes envolvidos, sobre como o Poder escapa a uma interpretação derivada da Teoria de Estado. Sobre como o Poder se mistura e se identifica com as próprias formas de 
produzir conhecimento, com a própria ciência, com a ciência médica. Finalmente, sobre como o Poder se relaciona com a Epidemiologia Clínica!

Algumas referências que Foucault usa para demonstrar essa concepção são muito interessantes. Ele reinterpreta Machiavel, ele se aproxima por uma outra e totalmente nova perspectiva do Leviatã de Hobbes. Ele mais que flerta com um dos fundadores do utilitarismo, o filósofo inglês da transição dos Séculos XVIII e XIX, Jeremy Benthan, para quem a natureza havia colocado a humanidade sob a governança de dois mestres soberanos: a dor e o prazer. Foucault sugere, em alguns de seus textos sobre esse assunto, que seria interessante explorar melhor a filosofia empírica inglesa do Século XVIII para conseguir entender toda essa questão. Suspeitava também que esse mesmo pensamento teria que ser visitado se realmente quisesse entender as regras do método científico da forma como ele fora pensado pela Epidemiologia Clínica. Há até historiadores da Epidemiologia Clínica que remetem diretamente a essa tradição filosófica na figura do autor em que aprofundei minha análise, David Hume (Morabia, 1991; 1996). Sem contar o próprio A. Feinstein, um dos fundadores da Epidemiologia Clínica, que inicia suas publicações sobre o assunto com um tributo a um dos pais do sensualismo e do empirismo inglês, o filósofo do Século XVII, Francis Bacon (Feinstein, 1964). Resolvi, então, que estudar essa tradição filosófica era um desafio do qual não poderia me eximir de enfrentar. Nesse enfrentamento me dei conta, e, principalmente entendi a perspectiva foucaultiana, de que as noções de sujeito, de natureza humana, de humanismo, que emanavam dessa tradição filosófica eram bastante diferentes das que a outra tradição, como, por exemplo, a marxista, utilizava em suas elaborações intelectuais. Mais que isso, descobri que a maioria dos textos de área de Saúde Pública que havia lido para entender melhor a relação entre método científico e prática médica, usava Michel Foucault para referenciar suas conclusões a respeito da necessidade de uma maior humanização da medicina, numa perspectiva que, segundo minha visão, não era exatamente a que ele se referenciava quando criticava o conceito de humanismo. Conclui que realmente havia um espaço de reflexão a ser explorado. Foi assim que resolvi estudar a obra de epistemologia e de história de David Hume. Foi assim 
que ousei ligar a pragmática do registro de novos medicamentos com a pragmática da prática clínica, usando a noção de humanismo como amálgama.

Conclui que a representação (ou interpretação) do humanismo humiano que, defendo, contribuiu enormemente com o desenvolvimento técnico-científico não só da medicina, mas de toda sociedade ocidental, em muitos aspectos se aproximava da noção de humanismo de Montaigne, mas ela era desenvolvida em um formato muito mais racionalizável, muito mais científico. David Hume tinha uma pretensão mais ambiciosa do que Montaigne (aproximadamente dois séculos separam suas obras), a ele não interessava apenas separar o mundo do Homem do mundo de Deus, ele queria fundar uma ciência da natureza humana. Definir as regras que regem a ação humana. Regras que explicam a ação do homem em mais de uma dimensão, tanto na ambição de conhecer as leis do cosmos, o que hoje chamamos de ciência da natureza, quanto no convívio com os outros homens em sociedade, o que chamamos de ciência humanas. Hume através da sua ciência da natureza humana juntava essas duas dimensões. O subtítulo de sua primeira obra, "Tratado da Natureza Humana" (Hume, 2000), escrita quando ele tinha apenas vinte e cinco anos, e que foi na época muito mal compreendida é: "Como uma tentativa de introduzir o método experimental de raciocínio nos assuntos morais". Fomos nós modernos que resolvemos separar esses mundos. Seu objetivo era desmontar, observar, e depois remontar, as molas do relógio e ver as engrenagens do humanismo. Um pensamento extraordinariamente profundo!

Quando me dei conta de que uma mesma palavra, humanismo, poderia tanto atacar quanto defender uma prática médica direcionada pelas mesmas regras, ou seja, as regras do método científico em seu mais contemporâneo grau de racionalização, a Epidemiologia Clínica, conclui que uma abordagem interpretativa da noção de humanismo poderia ajudar na minha trajetória de correlacionar os dois planos. Resolvi enfrentar a tarefa de falar sobre a noção de humanismo, mas abordando predominantemente a tradição anglo-saxã. Nessa empreitada jamais abandonei a perspectiva de que a palavra "humanismo" é uma palavra fluida, de significações muito diversas, com um 
enorme potencial de produzir um "pensar" verdadeiro. Esse assunto será tratado na última parte desse trabalho.

Em resumo, meu descontentamento pessoal com a crítica existente na área de Saúde Pública sobre a articulação entre uma hipertrofia da dimensão técnicocientífica e a necessidade de construção de uma prática médica libertadora, me levou a concluir que a questão do que se chama humano deveria ser repensada. Leituras paralelas, sobretudo de filósofos que levantaram a questão sobre o que é o humanismo, como Montaigne e Foucault, me levaram ao berço da epistemologia científica contemporânea, me levaram a David Hume, e, em torno do seu pensamento, busquei juntar as duas dimensões em um novo formato racional.

Mas ainda me restava um problema a resolver na ambição de junção dos planos. Esse problema era identificar o assunto, dentro da Epidemiologia Clínica, sobre o qual deveria discorrer. Felizmente esse também não era um problema particularmente grave ou difícil de resolver. A própria Epidemiologia Clínica já ajudava a resolver a questão. O discurso da Epidemiologia Clínica tem em suas entranhas um muito interessante sistema de hierarquia dos seus instrumentos de produzir verdade. Há o que vale mais e o que vale menos. Os ensaios clínicos comparativos duplo-cegos são considerados os instrumentos de análise clínica mais rigorosos que existem, e não por pura coincidência, como demonstrarei, eles são os modelos que passaram a ser empregados para se registrar um novo medicamento, inicialmente nos Estados Unidos, e, depois em praticamente todo o mundo. Portanto, foi em cima dos estudos comparativos que centrei minha análise.

Portanto, esse trabalho procura se situar em dois planos conceituais, o da epistemologia médica, e o da utilização do conhecimento científico na prática clínica. Para articular esses dois planos, busquei uma intercessão de discursos que passam por ambos. Utilizei um método de investigação histórica, usei a história do registro de novos medicamentos como instrumentos de análise histórica, e, tratei as regras da Epidemiologia Clínica e a noção de humanismo 
como matéria prima dessa análise. Finalmente, indexei nos estudos comparativos de eficácia terapêutica como o centro da articulação discursiva.

\section{O Método}

Na discussão do "Problema" já fiz uma primeira introdução ao método quando disse que optara pela abordagem histórico-epistemológica para juntar os planos de produção de conhecimento com a prática clínica. Pretendo agora avançar em dois aspectos desse método que foi minha escolha.

O primeiro é a questão da exterioridade ao objeto estudado. Minha primeira intenção, e até realização, quero dizer, nas primeiras tentativas de escrever o texto, tinha como objetivo construir um "aparelho interpretativo" que fosse neutro, quero dizer, que olhasse o problema de fora dele. A idéia era construir um método de análise que, diante das evidências extraídas dos documentos analisados, conseguisse provar a relação histórica entre os interesses econômicos da indústria farmacêutica e o método científico, as regras da Epidemiologia Clínica, que surgiu exatamente no mesmo período em que esses interesses estavam sendo questionados. A partir de uma vinculação direta com a hipertrofia da utilização do aparelho técnico-instrumental na prática médica e a conseqüente desumanização desta, seria um passo relativamente fácil de ser dado. Esse era o plano.

Acontece que, em algum momento, percebi que esse método estava me criando mais dificuldades do que soluções. Percebi que a exterioridade total era virtualmente impossível. O curioso dessa percepção foi fato de que esse é um pressuposto básico de vários autores que, direta ou indiretamente, utilizo ao longo de quase todo o meu texto (Adorno, 2007; Ayres, 2002; Gadamer, 2004 a, b; Gadamer, 2006; White, 2008). Ele é tão básico, que foi exatamente sua incorporação, um dos elementos que me fez questionar tanto o poder de produzir verdade em medicina por parte da Epidemiologia Clínica, quanto a necessidade de explicitar que uma mesma história, como a história do registro de novos medicamentos, pode ser contada de várias formas, todas legítimas, 
como procurarei descrever logo abaixo. Em ambas as dimensões, tanto nas ciências formais matematizáveis, como nas ciências humanas, queria partir da concepção de que o observador sempre, em graus e formatos diferentes, interfere nos resultados observados em seu objeto.

Ou seja, do ponto de vista da construção de um método de análise que estava elaborando para esse trabalho, fui vítima exatamente daquilo que condenava. Isso foi muito enriquecedor em todos os sentidos. Cito-o nessa introdução, e em particular na descrição da questão do método, para deixar claro que assumo como um importante aspecto do método histórico-epidemiológico empregado, o fato de que a simples construção mental do problema no formato como eu o fiz já significa uma tomada de posição em relação às conclusões apontadas. Minha vida pessoal, minhas experiências profissionais, o contato com meus amigos (e inimigos também), minhas leituras, e, todos os meus sentidos e capacidade cognitiva, queriam de alguma forma estabelecer limites para a utilização na prática clínica das verdades proferidas pelo maquinário da Epidemiologia Clínica, queriam buscar um caminho que genuinamente ajudasse na maior humanização, ou outro termo que ainda não tinha muito claro, pois não me sabia um humanista, da prática médica. Sob essa perspectiva, e, refletindo retrospectivamente, todo resto me parece apenas um detalhe!

A segunda questão relativa ao método que devo abordar é a opção que fiz de contar a história do registro de novos medicamentos nos Estados Unidos de duas formas distintas, cada uma antecedida por uma breve descrição de formas de se fazer história. As intenções escondidas nessa decisão podem não ser facilmente identificadas nos textos que escrevi, portanto, nos parágrafos abaixo vou tentar antecipadamente explicar esse melhor ponto.

Denominei a primeira narrativa de "história oficial do registro de novos medicamentos nos Estados Unidos". Essa parte foi precedida por uma descrição do método de análise historiográfica do pensador norte-americano Hayden White (White, 2008). Trata-se de uma descrição um pouco técnica demais, cujo objetivo, no contexto do trabalho é, principalmente, tratar a forma 
oficial com que os fatos relativos ao registro de novas drogas com certa ironia. Esclareça-se que, a ironia aqui não tem o sentido de deboche ou descaso, mas, o sentido construído pelo próprio Hayden White. Isto é, não se trata absolutamente de descredenciar os dados apresentados ou a história conforme contada, mas, de descortinar o véu da verdade absoluta em história. Mostrar que o caminho da progressiva depuração do erro em ciência e da falta de liberdade em uma sociedade civilizada, personagens principais da historia oficial, pode e deve ser questionado. O uso da ironia é, na obra de White, um poderosíssimo instrumento de retórica, ele a usa para sua própria obra, construindo um interessante sistema onde a verdade última dos textos históricos, inclusive os seus, é sempre colocada no banco de réus.

O motivo que me fez lançar mão desse instrumento retórico também tem relação direta com a minha trajetória ao escrever esse trabalho. Ao analisar a documentação específica sobre o assunto, e também ao conversar com agentes diretamente envolvidos na questão, refiro-me principalmente a alguns profissionais do Food and Drug Administration (FDA), em particular auditores e as pessoas responsáveis pelo departamento de história dessa agência, me surpreendi com o fato de que essa trajetória de progressiva racionalização científica era considerada auto-evidente. Questioná-la não faria o menor sentido. Mesmo que se lograsse demonstrar uma relação estreita entre os interesses particulares da indústria farmacêutica e a construção do edifício regulatório nos Estados Unidos, desenvolvido em torno das regras da Epidemiologia Clínica, mesmo assim, a possibilidade de uma crítica a uma interpretação que colocasse a liberdade e o desenvolvimento científico como principais protagonistas da história era tratada como um exotismo, pois afinal de contas, me diziam alguns desses interlocutores: qual o problema de se defender interesses particulares? Ficava de alguma forma implícito, que era exatamente isso que deveria ser feito. $E$, então, as coisas novamente se embaralhavam na minha cabeça. Perguntava-me: O que exatamente os interesses da indústria farmacêutica podem ter a ver com os fundamentos de uma ciência milenar como a medicina? 
Nesse cenário, considerei que o uso de uma certa ironia contida seria útil para a defesa de minhas posições. A descrição dos fatos oficiais de uma forma não muito aprofundada, às vezes um pouco superficial mesmo, visa se apropriar de uma parte do método do White ao exercitar a figura retórica da ironia, que tem como um de seus pressupostos básicos o fato de que a maior parte dos historiadores escolhe os fatos que quer descrever previamente à construção do texto de sua história. Esse é um elemento fundamental na obra desse autor, ele deixa claro, inclusive para sua própria obra, (que, repito, é tratada com uma certa ironia circular), que há sempre um processo de seleção do material que vai ser utilizado, privilegiando alguns textos, ou idéias, que corroboram com a posição poética do autor, e escondendo outros que enfraquecem essa posição. Quero chamar a atenção para o fato de que no caso do método que empreguei, apesar de ter consciência de que não escapei dessa forma de selecionar argumentos, procurei, sobretudo na descrição do que chamei de história oficial, reproduzir, quase que literalmente a história conforme contada pelo próprio FDA. É quase a tradução de uma versão. Reitero que meu objetivo é realmente fazer essa história ganhar um tom um pouco caricatural. Tenho a mais completa consciência que essa mesma história poderia ser contada, no mesmo formato, mas com detalhes muito maiores, e que esse procedimento poderia ajudar a esclarecer muitos fatos, inclusive a tese que defendo. Optei entretanto, por outro caminho. Por exemplo, a simples menção de forma tão superficial da U.S. Pharmacopeia já deveria fazer qualquer historiador profissional abandonar a leitura desse texto. As complexas relações dessa instituição com todo o edifício regulatório dos Estados Unidos são tão grandes e profundas que mereceriam, por si só, um aprofundamento muito maior. Acontece que não sou, nem pretendo ser um historiador profissional. Estou apenas usando "utilitariamente" a história do desenvolvimento de novas drogas como uma forma de articular os dois planos de meus interesses conceituais.

Finalmente devo esclarecer que, do ponto de vista narrativo, além do aspecto da ironia que já destaquei, queria com esse método, construir uma espécie de infraestrutura de informação que chegasse até a década de 1960, em particular à Emenda Kefauver-Haris (mais tarde descreverei em detalhes o que é essa 
Emenda), ponto a partir do qual começo minha análise arqueológica do registro de novos medicamentos nos Estados Unidos.

Essa parte da introdução não ficaria completa se não mencionasse o fato de que, dentro da obra de White, há um espaço para escapar da ironia no sentido que descrevi acima. Isso será mais adequadamente abordado quando descrever o método do White, em particular a questão da ironia em sua obra. Reconheço que essa descrição, até esse momento, foi excessivamente cética, como se não houvesse uma saída possível para relatividade dos resultados do empreendimento historiográfico. Contudo, White, ainda que novamente valendo-se do poder retórico da ironia, abre um espaço para uma saída positiva para fora desse neopirronismo. Procurei, através do método que empreguei, habitar esse espaço.

\section{As Fontes de Informação}

Pode-se dizer que são três os blocos de informação que foram consultados e utilizados nesse trabalho. $O$ primeiro refere-se aos fatos relativos à história do registro de novas drogas nos Estados Unidos.

A primeira fonte de informação que li foi um muito interessante livro escrito por um advogado inglês especializado em contenciosos relacionados com a indústria farmacêutica, particularmente na posição de defendê-la, mas que nunca perde a perspectiva crítica. Esse livro chama-se "The Law and Ethics of Pharmaceutical Industry", o nome do autor é Graham Dukes (Dukes, 2005). A leitura desse livro produziu em meu espírito um enorme impacto. Além de pela primeira vez ter lido toda a história da questão do registro de uma nova droga em um formato organizado cronologicamente, surpreendi-me com a conclusão que ele chega de que, toda a legislação escrita e utilizada pelas agências regulatórias dos países que detêm a tecnologia para desenvolver novas drogas foi construída através de um processo de auto-regulação. Segundo Dukes, apesar de todas as partes envolvidas terem participado, opinado e decidido coisas, todo o processo (e usando o mesmo verbo que ele usa), foi 
secretariado pela indústria farmacêutica. Nesse livro tive também, pela primeira vez, contato com o nome das personalidades que ditaram as regras da construção do método científico para o registro de novas drogas, como o Prof. Louis Lasagna e o Prof. Cooper. Realizei com uma certa surpresa que, autores renomados, pelo menos no mundo acadêmico, na área de Epidemiologia Clínica, como A. Feinstein e D. Sacket, sequer eram referenciados como possíveis protagonistas dessa história.

Esse último fato foi muito importante para mim, não só porque me fez refletir sobre o que achava que sabia sobre o assunto que queria estudar até aquele momento, como, também, porque me fez redirecionar o método de análise que iria empreender. Acontece que todo meu interesse inicial estava ancorado em uma série de artigos escritos pelo epidemiologista Alvin Feinstein em 1964 e que foram publicados no Annals of Internal Medicine (Feinstein, 1964). Esses artigos têm uma enorme densidade de um discurso epistemológico formal. Fala-se em empirismo, indutivismo, realismo, etc... Como já citei, eles remetem à tradição histórico-filosófica do empirismo de Francis Bacon, e dizem que o que faltava à medicina clínica daquela época era um aumento da valência empírica dos dados utilizados para a tomada de decisão médica individual. É muito mais uma obra de filosofia empírica do que de medicina clínica. Era esse material que me fazia pensar em direcionar meus interesses para uma discussão sobre epistemologia no sentido formal do termo. Entretanto, quando percebi que, mesmo uma década depois, esse material não era citado (nem seu autor) nas publicações que analisei sobre o assunto, e, principalmente, pelo fato de que o mote principal das discussões a respeito de como se provar cientificamente que uma droga era eficaz passavam muito mais por questões de natureza prática, como interesses econômicos e regulamentação legal, do que por questões relacionadas à epistemologia e história e filosofia da ciência, decidi que deveria privilegiar em minha análise uma abordagem que contemplasse predominantemente essas primeiras questões.

Além disso, outro importante acidente de percurso investigativo me fez mudar de idéia com relação a que tipo de material deveria privilegiar em minha análise. Inevitavelmente essa introdução mistura um pouco as coisas. É um 
ensaio. Estou falando sobre fonte de informação, mas, para conseguir explicar a escolha dessas fontes, devo voltar à questão do método. Nesse ponto em particular, devo esclarecer que, a literatura específica relacionada com o nascimento da Epidemiologia Clínica, as publicações dos anos 1960 e 1970, do Feinstein e do Sacket (Jaecshke, 1994), (Sacket, 1985), foram deixadas de lado como matéria principal de análise. Já citei dois motivos do por que tomei essa decisão: uma abordagem histórica poderia conter em seu interior os argumentos epistemológicos formais mais importantes, e, menos importante que isso, esses epidemiologistas não eram citados nos textos que li como participantes da história de como se construiu as regras científicas para 0 registro de novas drogas nos Estados Unidos. Vamos voltar ao outro motivo que me fez tratar essa literatura como secundária. Ele é um pouco anedótico, mas, é real.

Alvin Feinstein, autor da clássica obra: "Clinical Epidemiology: the architecture of clinical research", editor durante muitos anos da famosa revista Journal of Chronic Disease, posteriormente denominada Journal of Clinical Epidemiology, instituiu nessa revista uma seção denominada "Variance and dissent". O objetivo dessa seção, segundo editorial escrito pelo próprio Feinstein, era discutir assuntos controversos ou não ortodoxos na área de epidemiologia. Aproximadamente vinte por cento do material escrito e publicado nessa seção, discutia especificamente a questão do tabaco, e, na perspectiva de que o fumo passivo não poderia ser considerado como lesivo para o organismo humano. Não vale a pena entrar em detalhes sobre esse assunto, mas uma conclusão é obrigatória para que feche meu argumento. Demonstrou-se, anos depois, e isso foi bastante discutido em publicações, que Feinstein havia recebido aproximadamente um milhão de dólares da indústria do tabaco, para ser, nas palavras dos representantes dessa mesma indústria: " a most important individual for us to have available ". David Sackett, membro do corpo editorial da Journal of Clinical Epidemiology, que trabalhou com Feinstein por cerca de quarenta anos, e que o recrutou para trabalhar na famosa Universidade MacMaster, declarou para um autor suíço interessado na história da Epidemiologia Clínica, Dr. Alfredo Morabia, que nunca soube do envolvimento do colega com a indústria do tabaco (Morabia, 2002). Claro que essas histórias 
mereceriam um aprofundamento, um contraditório, uma defesa, mas repito, seja por esses motivos anedóticos, ou pelos anteriormente descritos, conclui que a análise formal dos métodos da Epidemiologia Clínica numa perspectiva epistemológica não me ajudaria muito a entender a relação entre os sistemas de produção de verdade em medicina e a utilização dessas verdades na prática médica cotidiana. Não que julgue que dados bibliográficos sejam direcionadores principais de questões complexas como as que estou tentando abordar, mas, não há como não reconhecer que, de alguma forma, essas coisas todas se entrecruzam. Ver um epidemiologista usar os instrumentos da epidemiologia para defender a indústria do tabaco não é um fato que pode simplesmente ser desconsiderado. Considerei-o, entretanto em uma perspectiva de exclusão.

Devido a contatos pessoais no FDA, tive acesso ao coordenador do Departamento de História dessa agência, e essa pessoa, além de, em mais de uma ocasião, se disponibilizar a conversar longamente comigo ao telefone, sempre de maneira extremamente gentil e cooperativa, me enviou dois artigos que tratavam especificamente sobre a questão da regulamentação de novas drogas nos Estados Unidos desde meados do Século XIX até a década de 1980 (Hutt, 1983 a,b). Passou-me também uma enorme lista de referências sobre $\mathrm{o}$ assunto. Da leitura desses dois artigos identifiquei que muitas informações originais sobre 0 assunto eram embates parlamentares, ou conclusões de Audiências Públicas realizadas na Câmara dos Deputados ou no Senado Americano. Tentei inicialmente acessar esse material diretamente, mas não tive sucesso. Descobri, então, que havia dois livros (Cooper, 1970; 1971), ambos editados pelo mesmo autor, o referido Prof. Cooper, que traziam não só as opiniões dele, que, como disse, foi um importante protagonista em todo o processo de regulamentação sobre a prova da eficácia e segurança de uma nova droga, como as posições individuais de vários participantes desses embates. Trata-se de um material extremamente rico em dados que traz até mesmo diálogos transcritos de fóruns realizados sobre o tema. Todo esse material, junto com as informações disponíveis na página da internet do FDA, foram as principais fontes historiográficas específicas sobre o tema, que foram utilizadas. 
O segundo bloco de informação são os textos de história e filosofia que dão suporte e funcionam como amálgama de toda a articulação discursiva desse trabalho. São textos clássicos. Por motivos já descritos anteriormente privilegiei uma análise especificamente relacionada ao que chamei de tradição do empirismo anglo-saxão. Há um motivo muito forte para isso e que já citei na seção anterior. Parto da idéia de que tanto as regras da ciência médica, quanto as regras morais que predominantemente suportam as sociedades que desenvolveram essas regras científicas, surgiram a partir dos princípios ontológicos e epistemológicos dessa tradição filosófica. Mas, é importante que se diga que, em minha opinião, qualquer aventura no mundo da filosofia, mesmo essa pobre incursão que realizei, descortina os critérios de verdade sobre a opinião de um autor qualquer, e acabam por revelar, sempre, conexões absolutamente insuspeitas. Não foi diferente comigo, o que me fez usar essas conexões sempre que julguei apropriado para a defesa dos meus argumentos.

Por último a questão do humanismo. Além de uma revisão breve sobre a noção de humanização em medicina no Brasil, analisando em maiores detalhes alguns desses textos, dois outros autores foram particularmente visitados:

O primeiro é o pensador francês falecido há cerca de vinte anos, Michel Foucault. Já me referi a esse autor como importante em toda minha argumentação. Da sua obra, também utilizei dois pontos em particular. $O$ primeiro, e mais importante, é sua análise do poder. Esta foi trabalhada particularmente quando abordei a questão das barreiras a um livre mercado de medicamentos. Esse é um ponto fundamental desse trabalho, e sua compreensão é absolutamente indispensável para que seus principais objetivos sejam compreendidos. O segundo ponto da obra desse autor é o que chamarei, por absoluta falta de uma locução mais adequada, de o seu "método histórico", em particular as questões discutidas na difícil obra denominada "Arqueologia do Saber" (Foucault, 2005 a). Uma descrição mais ou menos adequada do que quero dizer com "método histórico do Foucault", precederá toda a descrição do que chamei de uma arqueologia do registro de novos medicamentos nos Estados Unidos. 
O último autor que será particularmente visitado é o filósofo alemão contemporâneo Jürgen Habermas. Para interpretação do pensamento desse autor, usei além de algumas de suas principais obras (Habermas, 2002; 2003; 2004; 2006) um muito interessante intérprete do nosso meio chamado, Luis Repa que escreveu uma obra denominada: "A transformação da Filosofia em Jurgen Habermas: os papeis de reconstrução, interpretação e crítica" (Repa, 2008). O principal ponto do seu pensamento que será utilizado é a complexa noção de racionalidade que ele construiu, e como essa noção se articula com os critérios de cientificidade da medicina moderna. Procuro também dar um passo no sentido de entender como o conceito de racionalidade habermasiano pode ajudar a entender as conclusões desse estudo numa perspectiva humanista,. na busca da construção de um edifício de dados e interpretações que possibilitem a elaboração de um processo crítico sobre os limites e potencialidades do método científico quantitativo aplicado aos problemas práticos da clínica.

Esse é um ponto extremamente importante na motivação desse trabalho. Já declarei (e espero conseguir provar isso ao longo do texto) que me considero um humanista. Considero que a prática médica tem que ser sempre entendida numa perspectiva em que o Homem é a perspectiva principal que deve ser considerada. Todos os instrumentos, sejam estes de natureza teórica ou prática, tenham que estofos ideológicos tiverem, tenham que profundidade de análise tiverem,todos esses instrumentos devem visar o Homem em sua natureza, ou em suas manifestações, na natureza ou na sociedade, como sua meta final. Essas manifestações, por sua vez, podem ter os mais variados matizes. Podem ser um procedimento terapêutico de alta tecnologia, podem ser a descrição de uma noite insone ao lado de uma mãe que perdeu um filho em condições dramáticas e inesperadas, podem ser a racionalização gerencial de um atendimento médico em um pronto-socorro público, ou, podem também ser a prescrição de um medicamento inovador baseado em um sistema de produzir verdade construído pelas regras da Epidemiologia Clínica. Em todas essas formas de análise, em todas essas condições, parto da premissa, ou da postura ideológica, de que o objetivo de tudo isso tem que necessariamente ser 
o Homem. Tem que ser a construção de condições de possibilidade para que o homem se realize eticamente, o que quer dizer, valendo-me dos ensinamentos éticos de Aristóteles, que o homem seja mais feliz em sua trajetória pela existência. A questão com relação a essa postura ontológica, e que pode certamente gerar problemas de natureza interpretativa, é que, de alguma forma de me reservo o direito de pensar que, assim como para humanismo, a palavra Homem, no plano discursivo da filosofia, pode ser pensada de várias formas.

A utilização do conceito de racionalidade de Habermas, principalmente quando colocado ao lado da análise de poder do Foucault, associado, claro, a uma certa torção que, propositalmente, produzi no pensamento desses dois importantíssimos filósofos contemporâneos, teve como objetivo pavimentar um caminho que contribua para o trabalho intelectual, tão rico em nosso meio, de desenvolver uma prática médica mais humana. 
História Oficial do Registro de Novos Medicamentos nos Estados Unidos 


\section{Método histórico segundo Hayden White}

Escrever a história de qualquer coisa é sempre uma tarefa de risco. Fazer história é se abrir para o outro, se expor. Fora dos círculos das ciências naturais isso é uma espécie de verdade quase óbvia. A forma de argumentação e defesa dessa tese varia de alguma forma entre os vários autores de várias tendências e estilos, contudo, poucos ainda acreditam que os discursos históricos não sejam uma construção baseada em premissas previamente estabelecidas, sejam essas de natureza estética ou ideológica, ou ainda de outro parâmetro. Mesmo os grandes filósofos da historia, como Hegel, Marx ou Nietzsche, não escapam desse vaticínio, no dizer de White: "os modelos de representação ou conceptualização histórica não dependem da natureza dos "dados" que utilizavam para ancorar suas generalizações nem das teorias que invocam para explicá-las; depende, isso sim, da consistência, da coerência e do poder iluminador de suas respectivas visões do campo histórico". Ainda segundo o mesmo autor, os modelos de narração e de conceptualização histórica dependem, em última análise, da natureza preconceptual e especificamente poética de suas perspectivas da história e seus processos.

O modelo de raciocínio do cientista da natureza, incluindo o médico, sobretudo quando este não tem interesses específicos em assuntos relacionados com aspectos epistemológicos de sua ciência, costuma desconsiderar esse fato, ou tomá-lo como apenas periférico na prática de seu ofício de construir verdades. O desprezo por esse assunto no meio científico, sob a alegação de que ele carece de importância prática é muito grande. Os historiadores da ciência e os epistemológos são aves raras, exóticas, até um pouco aborrecidas. Essa visão, na interpretação de Gadamer, é encobridora e viciosa, para não dizer limitada (Gadamer, 1983; 2006). Mesmo nas ciências ditas positivas, posições a priori de interpretação da realidade são, de fato, o principal fio condutor que normatiza as regras de produção de verdade e as técnicas de interpretação 
dos dados. Abaixo será feita uma descrição da trajetória histórica para registro de novos medicamentos nos Estados Unidos no século passado.

A fonte mais tradicional sobre a história do registro de novas drogas nos Estados Unidos é o próprio FDA. Esta tradicional e renomada Agência Regulatória tem, em sua estrutura, um interessante departamento de história que, em geral, é consultado pela maioria dos trabalhos sobre o assunto. Dentro do incrível e, por vezes, fascinante formalismo que caracteriza boa parte da historiografia científica, sobretudo a relacionada com a medicina, destaca-se nos textos oficiais a construção de parâmetros que servem como guia para uma análise contextualizada na obra do autor referido acima, o historiador da História norte-americano, Hayden White (2008). A escolha desse autor, dentro desse contexto, é absolutamente intencional, e visa tentar construir um contra-ponto a introdução posterior que seguirá na próxima narrativa.

Segundo White, toda descrição histórica segue alguns parâmetros formais estáveis. Na principal obra do autor, denominada Meta-história, trabalho que demonstra uma erudição histórica impressionante, e que será abordado abaixo, dois aspectos são colocados em destaque:

Primeiramente o argumento já descrito, mas que por força de sua importância, não custa novamente descrever, de que, antes que o historiador possa aplicar aos dados do campo histórico o aparato conceitual que usará para representálo e explicá-lo, cabe-lhe primeiramente prefigurar esse campo, o que significa construí-lo como objeto de representação mental. Segundo o autor esse é um ato poético. Colocando esse argumento num plano pragmático, mais facilmente inteligível, pode-se dizer que, antes que um dado domínio histórico qualquer possa ser interpretado, primeiramente ele tem que ser concebido como um território claramente inteligível e deve ser povoado internamente por figuras que sejam, de alguma forma, discerníveis. Estas figuras, por sua vez, têm que ser classificadas como ordens, classes, gêneros e espécies distintas de fenômenos. Finalmente, estas figuras devem ser concebidas de modo que mantenham certos tipos de relações umas com as outras; que, em razão de 
sua dinâmica inter-relacional, o problema a ser explicado pela história narrada possa ser explicitado e eventualmente resolvido pelas explicações proporcionadas dentro da narrativa.

O segundo aspecto que chama a atenção no trabalho desse autor é a descrição das estruturas lingüísticas de uma obra histórica: arcabouço geral e suas figuras descritivas, o que ele chama de os três níveis em que operam os historiadores, com o objetivo de alcançar uma impressão explicativa em suas narrativas e as possíveis relações entre estes. De uma maneira geral, os três níveis operativos são: 1) o modo de elaboração do enredo, 2) o modo de argumentação e o 3) modo de implicação ideológico. Toda essa organização estrutural tem como objetivo construir uma obra magistral de análise dos métodos empregados pelos grandes historiadores do passado, em particular do século XIX, e está muito longe dos objetivos deste estudo promover uma crítica verdadeiramente aprofundada do método empregado por White, mas uma breve descrição de cada uma dessas categorias poderá ser útil para os objetivos dessa tese, uma vez que uma análise semelhante será aplicada à história oficial das exigências institucionais para registro de novos medicamentos, e algumas de suas possíveis contribuições serão empregadas no caminho.

\section{Modo de Elaboração do Enredo}

Entende White por modo de elaboração de enredo a via pela qual uma seqüência de eventos modelados em uma história gradativamente se revela como um tipo determinado. São quatro as forma de elaboração de enredo: o romance, a tragédia, a comédia e a sátira. $\mathrm{O}$ modo romanesco é aquele no qual o herói inexoravelmente triunfa, a despeito de todas as dificuldades que possa vir a enfrentar, sobre uma situação adversa. É o triunfo do bem sobre o mal, da virtude sobre o vício, das luzes sobre as trevas. Na sátira, vê-se exatamente o oposto, trata-se da disjunção, de um drama dominado pelo temor de que o homem seja essencialmente um cativo do mundo, e não o seu senhor, e pela consciência de que as ações humanas são sempre inadequadas 
para a tarefa de sobrepujar em definitivo as forças obscuras da morte. $\mathrm{Na}$ comédia e na tragédia, ao contrário da sátira, há a possibilidade de libertação, pelo menos parcial, do estado dividido e do rumo inexorável para a morte em que os homens se acham jogados no mundo. A manifestação dessa possibilidade, entretanto, difere radicalmente entre os dois formatos. $\mathrm{Na}$ comédia, a esperança de temporário triunfo do homem sobre seu mundo é oferecida pela perspectiva de reconciliações ocasionais das forças em jogo nos mundos social e natural. Tais reconciliações são observáveis nas festividades que normalmente coroam os relatos dramáticos de mudanças e transformações de formato cômico. Na tragédia, entretanto, não há festividades reais de natureza conciliatória, pelo contrário, o estado de divisão entre os homens se aprofunda à medida que o enredo avança. Todavia, a queda do protagonista e os desastres decorrentes da ação não são considerados ameaçadores para aqueles que sobrevivem à prova do embate. Para os espectadores do conflito houve uma aquisição de conhecimento e, este, consiste na epifania da lei que rege a existência humana. A pugna entre o protagonista, sempre derrotado, e a própria existência termina por produzir saber.

As formas arquetípicas de narrar ensejam outra característica de importância na análise do discurso histórico, qual seja, a distinção entre as narrativas diacrônicas, isto é processuais, e as de caráter sincrônico, ou estáticas. Não confere White, ao contrário de grandes epistemólogos contemporâneos, grande destaque a essa dimensão do discurso. Segundo ele, a distinção entre essas duas formas de representação histórica não deve ser tomada como métodos mutuamente exclusivos de cristalizar o enredo do campo histórico previamente definido.

\section{Modo de Argumentação}

O segundo nível de interpretação do discurso histórico denomina-se modo de argumentação. Aqui também quatro são as possibilidades de classificação: explicação por argumento formista, organicista, mecanicista e contextualista. Nesse nível, importa ao historiador explicar a finalidade do processo 
interpretativo, algo como: o que isso tudo significa no final das contas? Uma breve descrição de cada uma dessas categorias ajudará na compreensão da tarefa posterior de descrição histórica.

Entende-se por modo de argumentação formista aquela que mira a identificação de características ímpares dos objetos que povoam o campo histórico. Uma explicação só estará completa quando um determinado conjunto de objetos for convenientemente identificado, seus atributos de classe, tanto genéricos como específicos, forem marcados, e as etiquetas que atestam essa qualidade forem coladas. Esses objetos podem ser particulares ou universais, concretos ou abstratos, individuais ou coletivos. A mais marcante característica de um objeto numa descrição do tipo formista, contudo, é o fato de o historiador cuidar de destacar a percepção das similaridades que eventualmente pareçam ser partilhadas por todos os objetos do campo. A unicidade dos diversos agentes, agências e atos que compõem os eventos por explicar são fundamentais para as investigações, não o fundo onde essas entidades se manifestam. Para facilitar a compreensão: há um modo formista sempre que, por detrás de uma descrição histórica, vislumbramos algo como a essência de um povo, as características únicas e irreprodutíveis de uma revolução, a natureza singular de um processo.

O modo de argumentação organicista é mais integrativo em sua operacionalização. Ele tenta descrever os pormenores discernidos no campo histórico como componentes de processos sintéticos. Há no coração de toda descrição organicista um compromisso, nem sempre velado, de natureza metafísica. $O$ historiador organicista é regido pelo desejo de ver entidades individuais como componentes de processos que agregam em totalidades que são maiores ou qualitativamente diferentes da soma de suas partes. Esses historiadores estão mais interessados em caracterizar o processo integrativo do que em descrever seus elementos individuais. Outra característica importante do modo organicista é que ele tende ou se orienta para um determinado fim ou meta. Há sempre um componente teleológico nesse modo de escrever história. Apesar disso, o modo organicista se abstém de determinar leis que estabeleçam relações causais universais e invariantes ao processo histórico, 
ele prefere falar de "princípios" ou "idéias" que direcionam o processo rumo a um determinado fim. O filósofo alemão G. W. Hegel em particular, é considerado por White um historiador de cunho organicista.

As hipóteses mecanicistas são igualmente integrativas, porém ao invés de tenderem para a produção de sínteses, como no organicismo, tendem a um certo reducionismo. A teoria mecanicista da explicação apóia-se na busca de leis causais que determinam os resultados dos processos descobertos no campo histórico. Os objetos pertencentes ao campo histórico estudado são interpretados como existentes em suas relações entre si, e cujas configurações são determinadas pelas leis que, se presume, governam essas interações. $\mathrm{Na}$ análise de White, Marx talvez seja o mais célebre mecanicista. Sua imponente análise de relação causal entre infra-estrutura e superestrutura revela 0 objetivo de construir uma noção de natureza nomológica do Ser Histórico, predizendo leis que governam suas operações, expondo numa forma narrativa, os efeitos previsíveis dessas leis.

O último modo de argumentação é o que White denomina "contextualismo". Sua explicação está contida no nome: pressupõe-se que os eventos possam ser explicados ao serem postos dentro do contexto de sua ocorrência. Por que ocorreram e como ocorreram há de ser explicado pela revelação das relações específicas que têm com outros eventos que ocorrem no seu mesmo tempo histórico. Este tempo histórico é concebido como uma rica textura que, à primeira vista, parece não ter nenhuma ordenação interna, ou mesmo coerência estrutural. O contextalista aborda essa aparente confusão entre os vários elementos de um contexto histórico, buscando, na inter-relação funcional entre eles uma explicação coerente para o que e como aconteceu, de fato, o narrado. Essas inter-relações são interpretadas como relações reais que, se presume, tenham ocorrido em tempos e lugares específicos, contudo, suas causas primeira e final, nunca poderão ser conhecidas. A idéia não é integrar todos os eventos e tendências que possam ser identificados em todo o campo histórico, mas, reuni-los numa cadeia de caracterizações provisórias e restritas de espaços restritos. As explicações de caráter contextualista tendem para uma forma sincrônica de representação dos fatos narrados. A descrição 
temporal perde parte de sua homogeneidade, os cortes, ou momentos especiais, tendem a ganhar maior importância relativa. Sou particular e esteticamente afeto a esse modo.

\section{Modo de Implicação Ideológico}

O terceiro e último nível é o chamado modo de implicação ideológico. Este nível, ou dimensão, reflete o elemento ético da postura individual do historiador sobre a questão que ele está narrando, e ajuda a entender as implicações que podem ser inferidas dos acontecimentos passados para o entendimento do presente. White define como ideologia "um conjunto de prescrições para a tomada de posição no mundo presente da praxis social e a atuação sobre ele (seja para mudar o mundo, seja para mantê-lo no estado em que se encontra)". Novamente, quatro modos compõem esse plano: conservador, anarquista, radical, e liberal. O conservador imagina a evolução histórica como um aperfeiçoamento progressivo da estrutura institucional vigente, estrutura esta que é, a seus olhos, uma utopia, ou seja, a melhor forma de sociedade que os homens podem realisticamente contar, ou a que podem legitimamente aspirar por enquanto. Os liberais imaginam um tempo futuro em que essa estrutura terá sido melhorada, mas projetam esse estado utópico num futuro distante, de modo a desencorajar no presente qualquer tentativa de concretizá-lo precipitadamente por meios radicais. Já estes, os radicais, tendem a ver 0 estado utópico como iminente, o que lhes incute o interesse de achar os meios revolucionários de realizar o quanto antes essa utopia. Finalmente, os anarquistas caracterizam-se por idealizar um passado remoto de inocência natural humana da qual os homens caíram em um estado social imperfeito no qual se encontram no presente. Para os anarquistas, para que o homem histórico atinja essa utopia, ele deve, numa perspectiva não temporal, ou seja, a qualquer tempo, se apossar novamente de sua humanidade essencial, e esse reencontro deve promover a destruição de uma crença socialmente estatuída na legitimidade da instituição social vigente. 


\section{Os Tropos de Linguagem}

Após essa descrição geométrica de como analisar um texto histórico o autor dá seu verdadeiro salto no terreno da lingüística. Ele afirma que um historiador se defronta com o campo histórico que pretende descrever mais ou menos da mesma forma que um gramático se defronta com uma nova língua. Seu primeiro problema consiste em distinguir os elementos léxicos, gramaticais, e sintáticos do campo. Só após esse passo ele será capaz de interpretar o que significam as configurações dos elementos analisados e suas relações. A questão inicial do historiador, portanto, seria construir um protocolo lingüístico, devidamente preenchido com suas dimensões léxicas, gramaticais, sintáticas e semânticas e, com esse protocolo, caracterizar o campo onde sua narrativa deverá fluir. Um aspecto fundamental do pensamento de White é que esse protocolo, como já vimos anteriormente, tem uma natureza essencialmente prefigurativa, vale dizer: poética. Ele difere essencialmente dos documentos referenciados, apesar destes serem sua base empírica de construção narrativa. A fim de imaginar "o que realmente aconteceu" no passado, o historiador deve prefigurar como, "objeto possível" do conhecimento, o conjunto completo de eventos referidos nos documentos. Nesse ponto a descrição estrutural que até aqui foi feita das formas narrativas começa a ganhar corpo e inteligibilidade. Os vários planos (ou modos) devem se articular de alguma forma para que análise se complete, para que ganhe estatuto de método. Essa articulação não ocorre de forma livre, ou seja, os quatro modos de elaboração de enredo, os quatro modos de argumentação, e, os quatro modos de implicação ideológica, combinam-se entre si de forma finita. Nem todas as possibilidades de correlação são legitimas.

As estratégias de combinação têm, elas também, apenas quatro possibilidades que, não surpreendentemente, correspondem aos quatro principais tropos da linguagem poética: a metáfora, a metonímia, a sinédoque e a ironia. Portanto, as categorias empregadas para analisar os diferentes modos de reflexão, representação e explicação dos discursos históricos, seguem exatamente as mesmas modalidades da linguagem utilizada pelos poetas em suas divagações! (Estamos ainda no terreno da história, onde uma conclusão como 
essa pode não causar tanta polêmica, principalmente porque o senso-comum quase que assume a relatividade do discurso histórico - ainda que, reconditamente, sonhe com sua Verdade a ser revelada - mas vai chegar o momento em que teremos de enfrentar as premissas constitutivas do discurso científico médico contemporâneo e sua racionalidade histórica). Uma descrição das características dos tropos da linguagem em relação ao discurso histórico será a última parte dessa introdução à história oficial do registro de novos medicamentos nos Estados Unidos.

Uma breve descrição dos tropos ou das figuras de linguagem (ou figuras de retórica ou, ainda, figuras de estilo), apesar de fora do seu contexto acadêmico tradicional não se configura, no caso desse trabalho num detalhe sem significância, ao contrário, uma vez que é exatamente baseado numa análise da linguagem que a construção teórica desse trabalho se situará. Entretanto, detalhes técnicos e polêmicas classificatórias ou taxonômicas serão propositalmente omitidas em nome de uma tentativa de clareza na argumentação. Com efeito, as figuras estruturam a própria linguagem, potencializam o discurso, carregam com expressividade a fala, realçam o que Roman Jakobson (Jakobson, 2008) denomina "função poética da linguagem", sendo que toda linguagem é poièsis, vale dizer, criação. Tradicionalmente, há um repertório infindo de figuras de linguagem, com nomenclaturas diversas, heterogêneas e, até, contraditórias. A própria ambigüidade da classificação das figuras revela a natureza conotativa de todo discurso: a denotação seria, então, uma utopia, na medida em que o poeta (ou o autor), por exemplo, almeja que a palavra seja a coisa, o ícone seja o real, o signo seja o ser. Para além da polissemia de todo enunciado, as figuras também se misturam, configurando um concerto significativo.

Dentro da mais clássica tradição retórica, as figuras pertencem a quatro famílias: segundo afetem o aspecto sonoro ou gráfico das palavras, o aspecto semântico das unidades, a disposição formal da frase ou o valor lógico e referencial da proposição, operando funções de supressão, acréscimo, substituição e permuta. Eis os quatro grupos: 1) os metaplasmas, ou figuras de dicção, que recobrem tanto figuras gráficas quanto figuras fonéticas (apócope, 
síncope, anagrama, diérese, sinérese, neologismo, paronomásia, aliteração, assonância, calembur, sufixação parasitária, rima...); 2) os metassememas ou tropos ou figuras de palavras, que reenviam à mudança de significado, isto é, projeta-se um significado outro da palavra, diferente de seu significado "normal", "literal" (metáfora, metonímia, sinédoque, comparação, antonomásia, perífrase, sinestesia, alegoria, catacrese, parábola, símbolo, silepse...); 3) os metataxes ou figuras de construção, que atuam sobre a frase, a ordem das palavras, a gramática, que agem no plano sintático e formal, alteram a estrutura habitual da frase (elipse, zeugma, pleonasmo, assíndeto, polissíndeto, hibérbato, inversão, hipálage, quiasmo, parataxe, silepse, anacoluto, anáfora, aliteração, assonância, onomatopéia, oxímoro, tmese...);4) por último, os metalogismos ou figuras de pensamento, que concernem mais diretamente à linguagem, que se apóiam em idéias (litote, antítese, paradoxo, hipérbole, eufemismo, ironia, personificação ou prosopopéia, apóstrofe, gradação...). Outras taxonomias há das figuras de linguagem, mas, definitivamente não aprofundaremos essa discussão.

O que nos importa em toda essa classificação é defender, alinhado à posição de White, a proposição de que toda história contada tem seu fundamento em uma tomada aprioristica de uma determinada posição, e, que essa posição, se cristaliza, se materializa no estilo do historiador. A classificação em tropos de linguagem, como forma de entender o posicionamento intencional do historiador serve para, de alguma forma, situar o leitor nas reais intenções do autor. Reenviando o primeiro não às coisas de que fala, mas ao modo como as fala, o discurso histórico tem como primeiro significado a própria estrutura. Numa primeira interpretação da obra do White, a mensagem não se consuma jamais, permanece sempre como fonte de informações possíveis e responde de modo diverso a diversos tipos de sensibilidade e de cultura. $O$ discurso aberto é um apelo à responsabilidade, à escolha individual, um desafio e um estímulo para o gosto, para a imaginação e para a inteligência.

Para além, portanto, do estudo da linguagem propriamente dita, a investigação das figuras de linguagem aponta para a ideologia que habita cada descrição histórica. 


\section{A questão da ironia}

Como já descrevi na introdução desse trabalho, há na obra do White, um certo privilégio da ironia, figura que compõe o quarto tropo de linguagem da sua caracterização. Ele a usa freqüentemente, não só para analisar a obra de outros historiadores (particularmente interessante é interpretação de que o iluminismo, em particular a obra de D. Hume e E. Kant, cometeram o "erro" de tratar com ironia, e até um certo descaso, a tradição historiográfica préiluminista como se esta fosse não verdadeira, esquecendo que a sua própria forma de contar a história poderia também ser assim considerada), mas também para a sua própria obra. Parece que Hayden White faz absoluta questão de sempre relativizar as conclusões que ele mesmo chega, mesmo que essas sejam baseadas em dados de uma simplesmente inacreditável erudição, e, de um método de análise extremamente rigoroso. É como se procurasse sempre fugir da discussão sobre a verdade em história corajosamente encarando-a de frente. Entretanto, é importante destacar que desvela-se, após uma leitura um pouco mais atenta, um motivo para essa atitude. Vou descrevê-lo superficialmente para que o método que escolhi de contar a mesma história duas vezes seja mais bem compreendido.

White dizia que a tradição historiográfica do ocidente, a arte de fazer história dos Séculos XVIII e XIX, nascera em pleno apogeu dessa civilização; que todos os historiadores construíram métodos para explicar o sucesso dessa forma de viver, sua própria forma. O sucesso dos desenvolvimentos científicos, os sucessos dos desenvolvimentos políticos, os sucessos do desenvolvimento humano. A história seria uma forma de corroborar com essa tese de sucesso ininterrupto de uma determinada forma de viver e ver o mundo, de desenvolver essa tese em um quadro de argumentos que excluísse a possibilidade de que poderia ser diferente. Ele não exclui nem os autores, que segundo ele mesmo, procuravam escapar dessa tradição, apesar de, deve-se reconhecer, tratá-los de uma forma um pouco mais reverencial. Dois autores que ganham essa deferência especial de $\mathrm{H}$. White foram o alemão $\mathrm{F}$. Nietzsche e o italiano B. 
Croce. Os principais argumentos de White para defender essa posição são de que: 1) todo historiador sempre privilegia um determinado campo de ação, recorta um universo de análise que necessariamente acaba por excluir outro, que, eventualmente, pode ser seu vizinho e que poderia trazer novas e reveladoras perspectivas, 2) para analisar esse campo que já é privilegiado, o historiador seleciona dados (por exemplo, econômicos ou religiosos) que são também eles próprios, foros privilegiados, e, essa seleção, como no caso da delimitação do campo, também exclui outros dados que poderiam complementar, ou até refutar, a compreensão de todo o processo conforme a análise apresentada, 3) que para a análise desses dados deve o historiador escolher as fontes, e que essas podem ser análises históricas já processadas por outros autores ou fontes primárias ainda não processadas, em ambos os casos a escolha de uma determinada série de referências exclui sempre outras, que novamente, poderiam mudar o rumo das conclusões, 4) finalmente, há que considerar a audiência que vai ler a análise histórica, especialistas costumam ser muito mais rigorosos no julgamento dos três outros critérios acima do que não especialistas.

No caso desse trabalho, em particular, acredito que um médico, seja de que especialidade for, se interessará muito mais pela história que denominei oficial, por sua dinâmica discursiva e linear, relacionada diretamente com suas preocupações cotidianas, como intoxicações, mal-formações congênitas etc, do que pelos caóticos argumentos legais e econômicos que foram utilizados na segunda, que denominei de arqueológica. O que pode variar é o interesse por detalhes dos fatos, mas, de uma maneira geral, acredito que a forma de contar a história oficial do registro de novos medicamentos agradará mais aos leitores não interessados em questões de natureza epistemológica ou das implicações destas na prática do atendimento médico cotidiano. Ao contrário, se considerarmos um advogado, ou mesmo um funcionário de uma agência reguladora de medicamentos, talvez a segunda forma de contar história venha a ser mais interessante. Tenho a ambição de que, para um profissional da saúde pública, ou qualquer pessoa interessada na construção de uma prática médica mais útil e humana, ambas as versões vão interessar e se complementar. 
Todos esses quatro argumentos, que de alguma forma relativizam a verdade proferida por qualquer discurso histórico, fazem com que Hayden White dê uma grande importância à utilização da ironia como forma de narrar uma história. A idéia, repito o que já escrevi na introdução, não é descredenciar os fatos ou as conclusões, a idéia é, a partir da retórica da ironia, alertar sempre o leitor de que outras perspectivas podem e devem ser consideradas. Apesar disso, há um outro desdobramento interessante da utilização da ironia que deve ser descrito, e, que influenciou a realização desse estudo, sobretudo no formato em que foi feito. A obra do White não se restringe apenas a uma crítica destruidora dos discursos históricos através da estratégia de estampar a lógica da necessária relatividade dos instrumentos de análise historiográfica. Há uma outra dimensão, esta mais construtiva, e que diz que, conquanto uma postura crítica da história comece sempre pela percepção ou utilização da ironia, ela deve também procurar ir além dessa fase, descobrindo razões que justifiquem a eliminação desse elemento irônico. Sua superação. Há uma pretensão, que só se percebe claramente nos últimos capítulos da obra maior de $\mathrm{H}$. White, "Meta-história", uma espécie de esperança de que sua análise permita uma reflexão que conduza à construção de discurso histórico que seja autoconfiante, e, sobretudo, que se articule de uma maneira em que os dados apresentados realmente queiram dizer o que o autor de fato acha de como as coisas aconteceram. É uma espécie de ironia sobre o poder da ironia.

Assim termina a referida obra: "Não nego que o próprio formalismo de minha abordagem da história do pensamento histórico reflete a condição irônica em cujo interior é gerada a maior parte da moderna historiografia acadêmica. Mas sustento que o reconhecimento dessa perspectiva irônica proporciona os fundamentos para transcendê-la. Se se puder mostrar que a ironia é somente uma dentre numerosas perspectivas da história, cada uma das quais tem boas razões de existência num nível de consciência poética e moral, a atitude irônica começará a perder sua condição de perspectiva necessária à consideração do processo histórico. Os historiadores e filósofos da história estarão então livres para conceptualizar a história, perceber-lhe os conteúdos e construir narrativas dos processos históricos na modalidade de consciência que seja mais coerente 
com suas próprias aspirações morais e estéticas. E a consciência histórica estará aberta ao restabelecimento de seus vínculos com as grandes preocupações poéticas, científicas e filosóficas que inspiraram os praticantes e teóricos clássicos de sua idade de ouro no Século XIX" (White, 2008).

Vamos primeiramente ver com a história oficial da registro de novos medicamentos é contada. Qual a sua pré-configuraçao? A que audiência se dirige? Qual a sua poèsis? Depois vamos tentar contar essa mesma história de uma outra forma. 


\section{Food and Drug Administration (FDA) - A crônica de várias tragédias.}

Tomando White como base quase todas as referências bibliográficas analisadas sobre a história do FDA (Hutt, 1983 a,b;(U.S Departament of Health and Human Services. Overview on FDA history); Dukes, 2005) têm um caráter de crônica que pode ser enquadrada como um romance. A argumentação é do tipo formal, e os textos são ancorados em uma ideologia evidentemente liberal. Em resumo, e em linhas muito gerais, isso significa que: ao se abordar a história como um romance supõe-se que através da ação de um herói, o bem triunfará sobre o mal; a razão científica prevalecerá sobre as trevas do mito que procuram explicar as doenças. A história é contada em uma linha reta. Tanto do ponto de vista do desenvolvimento científico quanto dos aprimoramentos legais. Os fatos são registrados com uma retórica que, de certa forma, induz o leitor a concluir que o processo, guiado pela razão científica, foi conduzido da ignorância e do barbarismo para o saber e para a organização social. Ainda que essa versão seja legítima e até esteticamente muito interessante, vale a pena uma análise crítica de seu conteúdo narrativo.

A história oficial de registro de novos medicamentos nos EUA é narrada de uma forma em que apenas duas variáveis têm destaque no cenário. Os dois protagonistas da história são: 1) o desenvolvimento linear da razão científica e 2) o desenvolvimento do processo democrático, que, através de discussões sempre claras e objetivas, garantiu que a população pudesse exercer seu direito de desfrutar das novas tecnologias na área de medicamentos com segurança e eficácia garantidas. Esses dois protagonistas atuam num cenário que é marcado por tragédias, como a famosa história da talidomida nos anos 60 , e eles sempre, heroicamente, resolvem as situações. Reitero que a análise da obra de White prévia à história contada dessa forma tem o objetivo não de descredenciar as referências da história oficial, mas de construir um contraponto à história que de fato pretendo contar posteriormente. História onde os personagens são menos idealizados e, sobretudo, onde os objetivos 
morais e éticos das ações destes personagens não podem ser descolados do seu sentido pragmático, humano, mas, ao contrário, dependem deste para serem melhor compreendidos".

"Desde o início da civilização, as pessoas demonstram preocupação com a qualidade e a segurança de alimentos e medicamentos. Em 1202 o Rei da Inglaterra proclamou a primeira lei inglesa referente a alimentos, a denominada "Assize of Bread", que proibia a adulteração do pão com ingredientes como feijão e ervilha. Nos Estados Unidos, o início da regulação data de tempos coloniais daquele país. O controle federal sobre o suprimento de drogas começou com a inspeção das drogas importadas para o território americano em 1848...". Esse é o primeiro parágrafo do resumo da história da regulação de drogas nos Estados Unidos, estampado no site do FDA. A simples ligação histórico-conceitual de um ato do Rei da Inglaterra na Idade Média e um ato do executivo americano no século XIX já traz em seu ventre um evidente componente ideológico que merece algum escrutínio.

O primeiro marco regulatório importante do registro de novos medicamentos nos Estados Unidos é a criação da U.S. Pharmacopeia em 1820. Essa iniciativa merece um certo destaque porque resultou em um início de padronização de todo o processo. U.S. Pharmacopeia é uma organização não governamental, teoricamente sem fins lucrativos, cuja principal atividade é a identificação e produção de padrões considerados cientificamente corretos, para medicamentos, alimentos e outros produtos relacionados à saúde. Quando se quer testar se um determinado produto tem ou não qualidade de produção, basta compará-lo com os padrões estabelecidos pela U.S Pharmacopeia. Apesar dessa instituição não ser a pioneira no mundo nesse tipo de serviço, ela em geral é considerada como o padrão-ouro, em cima do qual todas as outras "pharmacopeias" do mundo, de alguma forma, se parametrizam. Portanto, situar o início da nossa história na fundação dessa organização é, como no caso do ato real do século XII, outra importante tomada de decisão. 
Vinte e oito anos depois, foi aprovado no Congresso americano, um ato denominado "Drug Importation Act", que obrigava às alfândegas inspecionar e identificar todas as drogas adulteradas que entrassem no país. A forma como isso era feito não tem muitos registros importantes. Olhar com nossos olhos pode parecer relativamente simples, mas se nos remetermos a quase dois séculos atrás, fica um pouco difícil de imaginar como as coisas eram de fato, na prática. A prova disso é que somente vinte e seis anos depois o Presidente Lincoln nomeou um químico para trabalhar no recém criado Departamento de Agricultura, onde fundou o Escritório de Química, que na verdade é a matriz original do que mais tarde seria o FDA. Um sucessor do fundador deste departamento, chamado Peter Collier, tentou sem sucesso em 1880, e baseado em suas próprias investigações sobre a adulteração de alimentos, aprovar no Congresso uma lei nacional que regulasse a produção e consumo de alimentos e drogas. A sugestão foi rejeitada, mas, nos vinte cinco anos seguintes, mais de 100 leis que tratavam do assunto foram incorporadas ao edifício legislativo norte-americano. Seu sucessor, Dr. Harvey W. Wiley, assume a responsabilidade política de levar o projeto de aprovar uma lei federal no Congresso, e dedica enorme energia a esse processo. Este cientista é considerado o pai do ato fundador do FDA.

Em 1897, dezessete anos depois da iniciativa pioneira do Dr. Peter Collier, o Congresso aprovou uma lei que obrigava que todos os importadores de chá custeassem a inspeção de qualidade pela qual seu produto deveria passar ao ingressar em território americano. No ano seguinte, e presidido pelo mesmo Dr. Wiley, fundou-se o primeiro comitê para determinação de padrões reprodutíveis de qualidade dos alimentos.

Até esse momento, o paradigma sobre o qual toda a discussão era conduzida baseava-se principalmente no controle alimentar. Não é difícil de entender que, naquela época, em uma nação que estava em pleno processo de se constituir, e onde a imigração trazia influências culturais de toda espécie, o consumo de alimentos adulterados ou produzidos sem qualquer rigor sanitário representasse um problema de dimensões verdadeiramente grandiosas, e que os conflitos de interesse entre população, produtores de alimentos, e governo, 
deveriam ser conduzidos no sentido de buscar uma solução consensual intermediada por algum critério que fosse aceitável por todas as partes, e considerado juridicamente racional. Não é o objetivo desse trabalho descrever essa história. Na verdade, sua descrição aqui atende apenas a um objetivo: preparar o terreno do ponto de vista histórico para o que veio a acontecer, muitos anos depois, com os medicamentos.

Na virada do século XIX para o século XX, na cidade de Saint Louis, várias crianças morreram devido à utilização de um soro antidiftérico contaminado com o Bacilo do Tétano. Essa é a primeira grande tragédia que ficou registrada nos anais oficiais, apesar de, muito provavelmente, muitas outras a terem precedido. Como conseqüência dessa tragédia, foi aprovado no Congresso o Ato de Controle de Produtos Biológicos que assegurava que todos os produtos dessa categoria, como soros e vacinas, antes de serem comercializados, tivessem assegurado sua pureza e segurança. Importa registrar que no resumo dos anais oficiais esse fato é omitido, identifiquei essa informação em outras fontes, em particular nos artigos já referidos do Hutt (Hutt, 1983). A aprovação do Ato se insere no movimento normal de racionalização do processo legal. No mesmo ano o congresso americano aprovou uma verba de cinco mil dólares para que os preservativos químicos colocados nos alimentos fossem mais bem conhecidos em relação à digestão e à saúde humana.

Após meio século, e depois de várias idas e vindas, a sociedade americana estava madura para aprovar uma lei nacional que regulasse a produção e comercialização dos alimentos e medicamentos que eram distribuídos em seu país. Em 30 de junho de 1906, o famoso Ato de Alimentos e Drogas (Food and Drug Act) foi aprovado pelo Congresso, e assinado posteriormente pelo Presidente Theodore Roosevelt.

Em 1911, em um contencioso do governo americano versus a empresa Johnson, a Suprema Corte do país decide que o "Food and Drug Act" não permitia ao FDA proibir que se divulgassem falsas alegações sobre os benefícios de um medicamento. A lei se restringia a assegurar a veracidade dos ingredientes e da identidade de uma droga. No ano seguinte, em 1912, e 
ainda sob a influência do contencioso descrito acima, foi aprovada uma emenda (Sherley Amendment) que proibia a divulgação de informações sobre resultados terapêuticos de uma droga que pudessem enganar o paciente que comprasse o produto. Naquela época, ao contrário de hoje, a dúvida era: como provar que um determinado dizer era falso?

Esse é um ponto importante sob o qual retomaremos a discussão, mas vale aqui uma digressão que no final atende aos objetivos desse trabalho. A relação entre a verdade, a ciência, a lei e a palavra escrita. O exemplo acima, que será mais bem descrito logo a seguir, é uma interessante encruzilhada de discursos. O que, afinal, pode ser dito sobre um medicamento? Quem legitima a veracidade de uma frase? Como lidar no mundo prático com uma dificuldade dessa natureza? Quem são os agentes que devem ser ouvidos? Quem se constitui como aquele que resolve as dúvidas, ou seja, quem é o fiel da balança da produção de verdade? Que língua assume essa posição? Como é a fala dessa língua? Quem fala essa língua? Qual o papel do médico praticante em todo esse processo?

O próximo capítulo dessa crônica aconteceu em 1914, quando um novo ato (Harrison Narcotic Act) exigiu que medicamentos com uma determinada quantidade de narcóticos tivessem que necessariamente vir acompanhados de uma prescrição médica. Em 1924, um novo e importante passo foi dado do ponto de vista legislativo, e que, de certa forma, nos remete ao parágrafo precedente sobre a linguagem. A Suprema Corte definiu que o Ato Fundador do FDA poderia condenar todos os ditos, desenhos e aparelhos de produtos, fossem medicamentos ou alimentos, que pudessem promover confusão ou enganar o consumidor. Voltamos à questão sobre a forma de registrar o que é considerado verdadeiro em medicina.

Entre 1933 e 1937 uma intensa batalha ocorreu para que o Ato Fundador do FDA fosse revisto. Muitos agentes consideravam, naquela altura, que havia uma defasagem institucional em relação a outros países, e que essa defasagem estava prejudicando a nação. Fato semelhante voltará a ocorrer quarenta anos depois, fazendo pensar que, realmente, há por detrás dessa 
história um determinante causal único. A discussão na época tratava de consolidar o poder regulador do Estado, porém, estava ainda longe de sugerir que algum tipo de revisão técnica, no sentido de produzir dados empíricos positivos de evidência clínica, produzidos previamente à autorização de um novo produto, fosse instituída, e, principalmente, que isso se tornasse uma exigência legal.

Em 1938 uma empresa chamada Massengill, começa a comercializar um elixir de sulfanilamida, usando como solvente dietileno glicol. Esta substância, apesar de considerada relativamente pouco tóxica, matou mais de cem pessoas, particularmente crianças que fizeram uso do produto. Esse é um novo marco na história da regulação de medicamentos novos nos Estados Unidos, porque, nessa data, um novo Ato foi enviado ao Congresso e aprovado no mesmo ano. Denomina-se esse ato de "Federal Food and Drug Act", e sua importância para este trabalho é, pode-se dizer, transcendental, uma vez que, a partir dessa data, passou a ser exigido que alguma comprovação científica de segurança de um novo produto fosse apresentada às autoridades sanitárias antes que este recebesse autorização legal para comercialização e divulgação..

Em 1940 o FDA foi transferido do Departamento de Agricultura para a Agência de Segurança Federal. As intercessões entre o discurso científico e jurídico se revelam em sua mais absoluta nudez. Mas ainda não é o tempo, nem histórico, relativo ao relato, nem histórico, relativo ao tempo, para abordarmos essa correlação. Nas décadas de sessenta e setenta, como veremos, esse assunto se tornará muito mais visível. Em 1943, a Suprema Corte decide que os representantes legais de empresas reguladas pelo FDA poderiam, independentemente de serem ativos e consciente de processos de má prática em negócios das entidades que representavam, serem considerados legalmente responsáveis pelas conseqüências que eventualmente poderiam advir dessas práticas.

Em 1941 uma Emenda ao ato de 1938 foi aprovada especificamente com relação à produção de insulina. Exigia-se que toda insulina comercializada 
tivesse sua pureza e potência biológica certificada pelo FDA. Em 1945, seguindo a mesma linha, mas em outra categoria terapêutica, passou-se a exigir certificação prévia do FDA para todas as penicilinas nos aspectos de eficácia e segurança, antes de comercialização dessas drogas. Logo depois essa exigência foi estendida para todos os antibióticos. Ainda estamos longe da certificação de eficácia clínica, que virá alguns anos mais tarde, como veremos. Um aspecto importante do Ato de 1938, e que não foi descrito, é que esse ato instituiu as inspeções nas unidades fabris de produtos farmacêuticos. Portanto, entre as décadas de trinta e quarenta, importantes e novas questões legais surgiram no mercado farmacêutico americano. De um lado, a exigência de produção com controle rígido de qualidade, por outro, a exigência de segurança antes de comercialização de novas drogas, e, arrematando tudo isso, a imputação legal de agentes que tenham interesse econômico na venda desses produtos.

Podemos dizer que o cenário está montado para o que estaria por acontecer na década de sessenta. Ciência médica e lei dialogam entre si para constituir um espaço de legitimidade formal. Pouco a pouco esses dois atores vão assumindo a posição de protagonistas da história.

Em 1950 um novo e interessante contencioso, quando visto sob uma ótica diacrônica, ocorre. Uma corte de apelações determina que quando um determinado dizer sobre uma droga é proferido, este tem que necessariamente se referir a uma determinada doença ou condição sobre a qual proclama seus benefícios. Novamente a questão da língua assume o proscênio. Todo esse embate se cristaliza em formas de falar, de escrever. Que regras regulam essa forma? Talvez seja um pouco de ousadia ver aqui a disputa trans-histórica entre o nominalismo e o realismo, mas o fato é que defendo a posição de que, no que tange a cientificidade da medicina contemporânea, o nome se confunde com o fenômeno. O método e suas palavras matemáticas assumem o papel da doença e do doente. A linguagem é a verdade. Não há, exceto para poucos críticos, uma barragem entre o significante e o significado. Talvez, entender a história desse método, ajude a contextualizar a língua que se fala no mundo científico médico contemporâneo. Talvez essa excursão filosófica ajude a 
entender porque estou tentando ligar a metodologia científica, conforme desenhada pelas regras da Epidemiologia Clínica, com uma prática médica predominantemente instrumental, no sentido weberiano do termo (Weber, 2006 c).

Em 1951, uma nova Emenda (Durham-Humphrey Amendment) define que tipo de droga não poderá ser usada de forma segura sem uma prescrição e posterior acompanhamento médico. Em 1952 o FDA passa ter consultores disponíveis nos distritos para poder ouvir os consumidores de saúde em suas necessidades e problemas. Em 1953 a Agência de Segurança Nacional, se desdobra e funda o Departamento de Saúde, Educação e Bem Estar (Department of Health, Education, and Welfare, HEW).

Em 1955 o Secretário do HEW institui uma comissão de catorze cidadãos para a adequação das instalações, recursos humanos e programas do FDA. Essa comissão recomenda formalmente um considerável aumento dos recursos que deveriam estar disponíveis à agência. Essa é uma discussão e reivindicação que persiste até os dias de hoje, com importantíssimos desdobramentos, sobretudo no que tange a forma de financiamento, como veremos em capítulo posterior.

Em 1962, uma nova, e importantíssima Emenda, foi aprovada. É a famosa Emenda Kefauver-Harris (Section 107 (c) of the Drug Amendments of 1962). Qualquer pessoa que estude a história da regulação sanitária com relação a drogas em qualquer lugar do mundo vai certamente se deparar com essa emenda. Suas principais exigências são, de que os produtores de medicamentos comprovem a eficácia e sejam mais rigorosos na certificação da segurança das drogas antes de sua comercialização. Ainda que a questão da segurança volte a ser destacada, vale lembrar que ela já tinha sido alvo de regulamentação no Ato de 1938, portanto já estava em vigor há vinte e quatro anos. A verdadeira novidade, que teve, a partir dessa data, várias repercussões no mundo da ciência médica, e, inúmeros desdobramentos políticos e econômicos, é, de fato, a exigência de comprovação prévia de eficácia para comercialização de drogas. Muitos desses desdobramentos serão 
avaliados em detalhes quando contarmos essa mesma história sob um outro modelo histórico adiante.

Não é sem importância para o objeto de nosso estudo o fato de que, no mesmo ano, o Presidente John F. Kennedy proferiu uma mensagem no Congresso que ficou conhecida como "Consumer Bill of Rights", na qual os seis direitos básicos do cidadão eram exortados: direito à segurança, direito a livre escolha, direito de ser ouvido, direito de ser informado, direito a ter acesso a educação, e, finalmente direito a serviços, sendo este último subdividido em: propaganda honesta, informações financeiras transparentes, e, finalmente, regras para embalagens e rotulagem (Consumer Bill Rights and Reponsability).

Como vimos, em meados do século XIX, com o "Drug Importation Act", a operacionalização da exigência legal demandou um suporte técnico e operacional que acabou sendo encontrado nas normatizações e padronizações da U.S. Pharmacopeia. Da mesma forma, em 1911, no contencioso do Governo Americano com a Johnson, identificou-se que o arcabouço legal do Ato fundador do FDA não permitia, na época, que a Agência cumprisse integralmente sua função de proteção da sociedade, o que demandou uma série de emendas e atos legislativos complementares. O mesmo aconteceu com a Emenda Kefauver-Harris. A exigência de comprovação de eficácia era clara, porém restava a questão, absolutamente primordial: como fazer isso? Como provar de forma inequívoca e consensualmente aceita por todos (consumidor, agência reguladora, produtor, poder legislativo e ciência médica) que uma determinada droga nova era de fato mais eficaz e segura em relação ao que já se praticava para o tratamento de uma doença? Outro ponto fundamental era como registrar esse fato? Que formatos deveriam assumir as evidências que confirmassem, ou refutassem, a tese de que a nova droga era de fato mais eficaz e segura. Sendo mais direto: Como provar e escrever de uma forma que fosse juridicamente correta que uma droga nova é eficaz? Esse processo levou muitos anos para se cristalizar, e é exatamente sobre ele que me debruçarei adiante com o objetivo de demonstrar que a metodologia científica utilizada pela clínica contemporânea teve suas origens não propriamente nos problemas clínicos, mas, na confluência de discursos 
heterogêneos e não necessariamente científicos, entendendo aqui científicos com referência às ciências da natureza. Antes, um antecedente importante da Emenda Kefauver-Harris tem que ser destacado.

A talidomida foi introduzida no mercado no ano de 1956 com o nome comercial de Contergan ${ }^{\circledR}$. Para além de um potente efeito sedativo e hipnótico, esta droga apresentava também características anti-eméticas, revelando, através de experiências com animais, uma toxicidade aguda muito baixa. Dadas as suas características farmacológicas, foi utilizada por mulheres grávidas no combate às insônias e ansiedade, e também no alívio dos enjôos matinais. A sua ação terapêutica permitiu que rapidamente fosse um êxito no mercado farmacêutico, atingindo grande popularidade, particularmente na Europa e no Canadá. Nos EUA, o FDA nunca chegou a autorizar a sua introdução no mercado, devido à descrição em periódicos científicos de ocorrência de alguns efeitos neurológicos raros - alguns doentes que tomavam este fármaco durante longos períodos de tempo relatavam períodos de perda de sensibilidade nas mãos e nos pés. Uma médica chamada Dra. Frances Kelsey teve papel fundamental nesse processo. Ela resistiu a um assédio arrogante e insistente. Segundo seu próprio depoimento, foi contatada por mais de cinqüenta vezes pela empresa detentora da patente da droga, para que aprovasse a rápida liberação da comercialização do produto nos EUA. Esta médica chegou a ser ameaçada com processo judicial, mas resistiu. No final foi condecorada por sua atitude com a maior homenagem que um civil pode receber do governo americano.

Foi esse processo que, segundo essa forma de contar a história, possibilitou o surgimento das condições político-institucionais que culminaram com a Emenda Kefauver-Harris.

Essa história culmina com uma heroína, a Dra. Frances Kelsey. Se somente usássemos Hayden White para nossas intenções historiográficas poderíamos simplesmente dizer que, a história oficial do registro de novas drogas nos Estados Unidos é realmente um romance onde o bem triunfa sobre o mal, onde a razão ilumina as trevas, onde a liberdade do Homem, após uma longa e dolorosa batalha, demonstra finalmente sua superioridade sobre os 
constrangimentos de uma sociedade totalitária. Até uma medalha a Dra. Frances Kelsey recebeu das mãos do mesmo homem, um verdadeiro príncipe de olhos azuis, o Presidente Kennedy, que defendeu os direitos inalienáveis do cidadão através da "Consumer Bill of Rights". É o primado do significado em relação ao significante. É o triunfo da metáfora. Felizmente, o próprio White nos abre a possibilidade de ver a história de outra forma. Seu sistema de estruturas narrativas nos permite arriscar vôos mais ousados referenciados nos mesmos documentos que dão suporte a essa narrativa heróica. A diferença é que, ao invés de construir um espaço privilegiado para o tropo da ironia, como faz White para seu próprio trabalho, vamos tentar navegar no espaço pluridimencional, e extremamente arriscado, da arqueologia.

Antes, contudo, cumpre terminar essa narrativa histórica com um epílogo que, de certa forma, alinhava o discurso até aqui realizado, e que nos coloca de frente com questões muito práticas relativas a como os critérios contemporâneos de cientificidade na terapêutica médica foram sendo moldados nos últimos anos.

Em 1966 o FDA contratou os serviços da Academia Nacional de Ciências a fim de avaliar a eficácia de quatro mil drogas que haviam sido aprovadas nos Estados Unidos no período de 1938 até 1962 com base apenas em critérios de segurança. Dois anos depois se formou o DESI (Drug Efficacy Study Implementation), um comitê que tinha como tarefa fundamental implementar as recomendações apresentadas pela Academia Nacional de Ciências em seu relatório final. Essa tarefa, de dimensões gigantescas, sobretudo se considerarmos que os arcabouços, tanto científico quanto legal, ainda estavam sendo construídos, levou vários anos para ser finalizada, tendo sido considerado concluído apenas no final da década de setenta, quase vinte anos após sua determinação legal. Foi nesse período que se formou o conceito moderno de "Eficácia Terapêutica".

Descreveremos no momento adequado, os métodos, as conclusões, e os desdobramentos políticos do DESI, e essa descrição será um dos argumentos que fundam as conclusões dessa tese. 
Uma arqueologia do registro de novos medicamentos nos Estados Unidos da América 
Parte I - Preâmbulo historiográfico 


\section{O conceito de ruptura}

A tradição histórica ocidental busca a criação de homogeneidades conceituais. Alinhava o tempo para construir essas homogeneidades. Busca um desenvolvimento linear e inexorável do homem e de suas relações em vários níveis. Do plano ético ao estético, do conhecimento sobre a natureza aos sistemas que dão suporte a esse conhecimento, os grandes historiadores profissionais e, sobretudo os seus multiplicadores em territórios específicos do conhecimento, buscam continuidades seculares através de conceitos em geral coagulados no presente como se eles fossem eternos. Curvas de sobrevida, taxas de complicações, exposições variadas, instrumentos diagnósticos ou terapêuticos, todas essas formas de analisar uma enfermidade transportam-se para um passado muitas vezes distante, e, ao serem analisadas no presente, carregam consigo todas as lutas, todas as heterogeneidades de um devir que escapa às interpretações modernas. A conseqüência prática desse processo é a construção de uma história das idéias e dos conceitos que tem basicamente duas características principais: a busca silenciosa e obstinada por uma origem, por um precursor original, e, mais importante, a construção de uma direção transcendental rumo a um progresso da razão, como se fosse o destino da espécie humana o conhecer ilimitado (Veyne, 1982).

Vários autores, embora de formas bem diferentes, mostram que a história de um conceito (Feyerabend, 2003; Kuhn, 2007; Koyré, 1986), não é de forma alguma, a do seu refinamento progressivo, de sua racionalidade continuamente crescente. Ao contrário, a construção de um conceito, sobretudo no mundo da ciência, passa necessariamente pela identificação de seus diversos campos de constituição e de validade, de suas regras sucessivas de uso, a dos múltiplos meios teóricos em que foi realizado, e, ao ambiente em que foi elaborado. Sob essa perspectiva, uma análise histórica faz surgir aos olhos do observador um sistema de interpretação totalmente distinto. Os acontecimentos e suas conseqüências não se distribuem na tessitura da história das idéias, ou de um discurso científico particular, de uma forma 
necessariamente articulada ou homogênea. Uma descoberta inovadora, uma idéia de um pensador ou a resistência de outro, constroem uma espécie de vitral, cuja observação e interpretação vai variar de acordo com a incidência da luz, de acordo com a estação do ano, de acordo com a hora do dia, de acordo com o senso estético e ético de uma época. As rupturas mais radicais são aquelas que promovem uma nova forma de ver esse vitral. É como se imagens escondidas e particularmente esclarecedoras surgissem no meio de um painel que há séculos já estivesse sendo observado. De acordo com a tradição marxista, que tanto influencia nossa concepção de história, esses momentos representam a fundação de um saber científico destacando-o do seu passado, e, revelando esse passado como substancialmente ideológico (Marx, 2003).

O modelo de interpretação histórica que pretendemos empreender a partir desse ponto para analisar o registro de novos medicamentos, e sua relação com o discurso científico contemporâneo, é diferente do modelo que acabamos de descrever e que chamamos de história oficial. Não vamos buscar estruturas fixas que representem o desenvolvimento linear de uma racionalidade instrumental e científica, não vamos alinhavar a história em nome de um desenvolvimento inevitável da razão, antes, vamos tentar penetrar numa inevitável multiplicidade de rupturas, e tentar desvelar algumas perturbações que a história oficial procura ou precisa esconder.

Outra inevitável conseqüência desse empreendimento será a interposição de planos que podem ser considerados heterogêneos. Um mesmo problema será analisado tanto sob a perspectiva econômica quanto científica. Esse mesmo problema poderá ter que ser, posteriormente, analisado sob uma ótica legal ou social. De campos de saberes distintos, heterogêneos entre si tanto do ponto de vista discursivo quanto do seu grau de positividade científica, pretende-se que uma nova epistemologia mais abrangente surja. A idéia é produzir um sistema de pensamento que procure analisar a cientificidade do discurso médico contemporâneo a partir de um espaço privilegiado, onde as regras internas desse discurso, coaguladas no presente, serão iluminadas não apenas por seus próprios critérios, mas por seus múltiplos determinantes, muitos heterogêneos a estes primeiros. 
Aqui é preciso um pouco de cuidado. A noção de determinante causal demanda algumas explicações prévias, uma vez que o que se está buscando não é a reconstrução da história da medicina, baseado em novos parâmetros de análise da história geral. Não se trata de estabelecer por referências específicas e diferentes uma nova história da medicina que será mais verdadeira do que a história oficial. A idéia é trazer à luz novos argumentos que ajudem a entender o presente das formações discursivas da medicina contemporânea. A idéia é tentar, através de novos dados históricos, promover a compreensão do presente, e vislumbrar saídas que ajudem na construção de uma medicina mais humana.

Ao invés da longa e única série de uma história que, como num vôo certeiro de uma flecha com destino determinado para o centro de um alvo, e, que tem como causa eficiente o progresso da razão científica para desvendar a natureza das doenças e achar a melhor forma de combatê-las, pretende-se reconstruir a mesma história, porém com múltiplas séries paralelas. Essas séries serão delimitadas, seus limites terão que ser definidos, e, suas relações múltiplas terão de ser descritas. Do entrecruzamento dessas séries pretendese formar uma nova série, que será uma espécie de série das séries selecionadas, e esta, terá o poder de ajudar na compreensão do problema. Como num quadro cubista, a idéia é descrever uma história, sob várias perspectivas e a um só tempo. O entrecruzamento de vários discursos funcionará como um retrato cubista de uma pessoa que, mostra na superfície da sua imagem, e a um só tempo, tanto a frente quanto o seu perfil. $\mathrm{Na}$ análise da formação do conceito de cientificidade da medicina moderna, veremos os discursos científicos, jurídicos e econômicos formando, ao mesmo tempo, esse conceito.

Talvez a diferença mais importante entre o método que pretendemos realizar e a história oficial que descrevemos, não esteja propriamente nos problemas que têm que ser abordados e resolvidos. Todo mundo que se aventura numa empreitada de natureza histórica, independentemente do caminho que trilhe, inevitavelmente acaba se deparando com os mesmos problemas: quais os 
critérios de verdade? Quais os conceitos fundamentais que suportam uma teoria? Qual o papel da observação empírica de fatos? Qual a relação entre teoria e prática? Qual o papel dos manuais? Quais os critérios de verificabilidade? Quais os limites entre ciência e discurso não científico? Muitas outras perguntas poderiam ser feitas, e, todas são importantes em um projeto de pretensões históricas e epistemológicas. $\mathrm{O}$ que distingue a abordagem que vamos empreender não é exatamente a natureza das perguntas, mas, a abordagem crítica dos documentos discutidos. Ao contrário da abordagem histórica oficial que apresentamos, e que fez dos documentos monumentos teleológicos que sustentam um rumo pré-definido de racionalidade científica, expurgando dados que não se coadunem com esse objetivo. $O$ trabalho que vamos empreender a partir de agora, abordará os documentos, porém em sua singularidade temporal e material. O objetivo é tentar decifrar os rastros deixados pelos participantes da discussão sobre o registro de novos medicamentos na defesa de seus interesses e posições e nas suas trajetórias de vida.

Outro aspecto que tem que ser descrito nessa introdução é que a questão da busca de uma ruptura na história não deve ser encarada como um simples acidente metodológico, um detalhe pouco importante que é o fruto de uma preferência estética do autor, que visa preencher lacunas na grande história da razão ocidental. A identificação dessa ruptura é antes um objetivo per si. Tratase de um trabalho ativo e que demandou considerável esforço e gasto energético. Isso por que, uma vez identificada, ela passa a representar um espaço privilegiado de observação, e ainda mais importante, de manifestação discursiva. É em cima dessa ruptura que vamos construir nossa argumentação. A ruptura na história das idéias (é sob esse pressuposto que vamos trabalhar em nossa história particular), ganha um significado de púlpito, onde, ao contrário de representar uma trajetória regular a ser construída, busca construir as condições para observar exatamente o oposto, ou seja, as mudanças de trajetória, os pontos insuspeitos e imprevisíveis presentes nas inflexões das curvas, o ponto mesmo em que um discurso científico pode se transformar em seu oposto, ou ao contrário, o momento em que um discurso periférico se transforma em protagonista de uma história. 
Dessa forma, teremos a descrição da história da ciência médica contemporânea nessas duas perspectivas metodológicas. De um lado a construção de séries, por outra a observação das séries sob uma perspectiva de descontinuidade. As séries são as histórias da economia, da legislação e dos critérios de cientificidade para o registro de novos medicamentos nos Estados Unidos nas décadas de sessenta e setenta. A ruptura é exigência imposta pelas crises econômica, científica e institucional para que esses critérios fossem reformulados, constituindo o discurso científico conforme conhecemos hoje em dia, e, que tem como fundamento os estudos clínicos comparativos.

Há uma outra característica metodológica que cumpre descrever em nome de uma tentativa de esclarecimento metodológico. Refiro-me às relações que podem existir entre as rupturas e as séries. É procedimento habitual da história das ciências buscar correlações espaço-temporais bem definidas e homogêneas. Identificar um denominador comum que permita explicar várias manifestações, muitas vezes heterogêneas entre si, através de um mesmo núcleo central (Foulcault, 2005 a). A análise por séries e descontinuidades abre mão desse hábito, mesmo sabendo que corre o risco de ser mal compreendida. Ao contrário de construir um ponto comum que explique fatos desconexos como: 1) a metodologia científica da medicina contemporânea, 2) a história do desenvolvimento tecnológico da ciência terapêutica, 3) a adequação da estrutura jurídica a esses desenvolvimentos, 4) a evolução econômica das sociedades ocidentais no pós-guerra e as crises que aconteceram nos anos sessenta e setenta, o que de fato se busca com esse método, é a identificação das conseqüências do jogo de correlação entre todas essas séries. A questão não é apenas saber o que liga as séries, mas, acima de tudo, como elas se diferenciam, e, que valência relativa cada uma dessas séries adquire quando colocadas lado a lado. Qual o poder de dominância relativa de cada uma das séries descritas no quadro geral do grupo discursivo?

Há ainda uma última dificuldade metodológica que deve ser enfrentada e esclarecida. Trata -se do grupo de documentos que deverão ser analisados. A 
escolha desse material em um estudo de natureza histórico-epistemológica, reservas grandes e insuspeitas dificuldades. Qual fonte de fato reflete um conceito, ou descreve uma forma hegemônica de pensar? Que texto melhor descreve um jeito de analisar, confirmar ou refutar uma proposta? Como já vimos, a escolha sempre, e, necessariamente, implica em riscos. Uma tomada de posição inicial praticamente define a trajetória, e, talvez até o desfecho do empreendimento. No caso específico do objeto desse estudo, algumas opções colocavam-se disponíveis desde o início. Dos manuais tradicionais de medicina, aos resumos dos últimos congressos de especialidades, passando por toda uma série de estudos e publicações sobre o assunto. A comparação de textos sobre assuntos técnicos em períodos de tempo diferentes, pareceres jurídicos, etc... Todas essas possibilidades seriam viáveis e de alguma forma poderiam chegar a interessantes conclusões. Contudo, para ser conseqüente ao método descrito nos parágrafos anteriores, um outro e diferente caminho foi escolhido.

Nas séries escolhidas, particularmente nas científica e jurídica, optou-se antes, por referências que são interpretações de embates legislativos. Discussões empreendidas por diferentes personagens, ou grupos de personagens, cada um representando pontos de vistas diferentes e defendendo posições distintas. O objetivo comum desses debates era chegar-se a um consenso que definisse os critérios de cientificidade para o registro de novos medicamentos, mas, os seus participantes não eram apenas médicos e cientistas. Economistas, empresários, juristas, pacientes, e cientistas todos participaram ativamente desse processo. Esse material, de acesso não muito fácil, reflete de maneira bastante sistemática, como e por quais caminhos, o discurso técnico-científico da medicina acabou se constituindo nesses últimos cinqüenta anos. Esse material que acabou por se consolidar num método de produzir verdade em um campo de transcendental importância para o ser humano, que é a medicina, paradoxalmente, pouco fala especificamente sobre o tema. Pouco se discutiu sobre o método propriamente dito. Este, na verdade, foi sendo construído em seus detalhes à medida que as necessidades foram surgindo. As argumentações têm freqüentemente, um caráter de debate, apesar de para cada assunto abordado, uma exposição preliminar ser sempre feita. Em cima 
dessa apresentação vários pontos de vista, em geral de diversas áreas, são apresentados e discutidos.

Esse formato dialógico, muitas vezes fragmentado, revela em seu contexto, mais do que simples análises ahistóricas coaguladas em um momento presente que pouco pressentia de seus verdadeiros determinantes históricos. A escolha desse material não traz conclusões fáceis, e, nos remete ao desconhecido. Buscar os fundamentos científicos da medicina contemporânea fora dos cânones dessa ciência, fora dos seus momentos históricos reconhecidos e aclamados pela academia é um arriscado convite a se debruçar sobre o outro do nosso próprio pensamento, a ser obrigado a reconhecer 0 devir como mais potente do que a estrutura, seja esta última pensada em que forma for. Na verdade insisto no ponto de que a história da ciência ocidental, com todas as suas realizações e potencialidades, carece de homogeneidades, de regularidades que a ajudem a projetar seus próprios próximos passos, de certezas que a tranqüilizem (e consequentemente tranqüilize a todos nós também) sobre um futuro que é sempre ameaçador e incerto. $O$ que realizamos como evidente em nossas próprias vidas, a imprevisibilidade, o acaso, a incerteza, o caos, procuramos escamotear quando transitamos em discursos formais como é o discurso científico. Penso que isso é inevitável.

Deve-se esclarecer que não se constitui como objetivo desse estudo uma crítica destrutiva aos modelos atuais de produção de verdade em medicina. Não se trata de sobre uma análise do modelo presente propor um novo em mais refinado modelo. De se contrapor um modelo a outro. A idéia não é desmascarar uma verdade constituída em nome de uma outra, mas completa e profunda. Não se trata de tentar calar uma tradição trocando-a por uma tagarelice arrogante. Trata-se de solicitar a palavra em um espaço vitorioso. Solicitar um passe de entrada, ainda que naqueles camarotes de teatros antigos de ópera, que nada vêem do palco e de onde ninguém consegue pressentir sua presença, onde apenas ouve-se e imagina-se, numa discussão que se impõe por sua relevância social. O que legitima o ato médico? Como entender o complexo sistema de valores que são os fundamentos do saber 
médico no presente? O que isso tem a ver com a forma com que se pratica a medicina hoje em dia? Como exercer uma crítica eficaz a esse processo? 


\section{A concepção de história na obra de Michel Foucault}

Há na construção epistemológica da obra de Foucault um ponto que sustenta quase como uma superestrutura do pensamento, a idéia de que a história clássica, com seus fundamentos de continuidade e homogeneidade, é uma espécie de correlato da função fundadora do sujeito (Foucault, 2005 a). Não vale a pena enveredar por esse arriscado e difícil terreno da tese foucaultiana, mas algumas palavras podem nos ajudar a situar melhor o método que vamos empreender e as conseqüências de suas conclusões.

Alinhar a continuidade histórica com a fundação do conceito de sujeito implica dizer, à moda hegeliana, que a história é o berço e o fim das realizações do espírito humano. Implica dizer que há um fim, um telos, na história da humanidade, e, que todas as dispersões e inconformidades serão um dia incorporadas a essa teleologia, e que esta nos conduzirá, inexoravelmente, a formas superiores de ser. Implica dizer que a razão da consciência histórica é uma espécie de síntese das múltiplas razões individuais dos múltiplos sujeitos racionais. É claro que não se constitui como objeto desse trabalho uma crítica à noção de história em Hegel. Essa é uma tarefa muito acima de minhas capacidades. Uma simples descrição da forma de escrever de Hegel poderia gerar vários volumes para várias teses em filosofia. Seu estilo hermético, frio, e instável, nos conduz a labirintos, de dentro dos quais, se não tomarmos cuidado, nunca mais sairemos. Então por que tocar nesse assunto? O que a noção de história em Hegel pode remotamente ter a ver com uma tentativa de fazer uma análise histórica do saber na medicina contemporânea?

Em primeiro lugar, é importante deixar claro que, quando se fala em história, não é apenas da grande história universal, daquela que lida com grandes períodos e suas estabilidades e continuidades, e que costuma ter designações fixas no nosso pensamento (feudalismo, mercantilismo, Idade Média, história da medicina), que se trata. Por detrás dessa grande história, repleta de grande simbolismo e representatividade em nosso pensamento, esconde-se, quase 
que voluntariamente, uma outra história nem tão homogênea, nem tão facilmente perceptível. Por exemplo, parto da hipótese de que dentro da grande história da medicina, há outras histórias como: o conceito de normal em biologia, o conceito de risco, ou, o assunto desse trabalho, a noção evolutiva da cientificidade de um tratamento médico, que têm que ser descritas para ajudar na compreensão da prática médica. A idéia é que todas essas histórias, e muitas outras, merecem ser descritas dentro de sua própria lógica, de seu próprio processo de desenvolvimento, utilizando-se das várias séries que as recortam.

O processo de linearização e homogeneização imposto pela grande história permeia de forma restritiva esses territórios particulares das séries históricas escandidas, como se, após a racionalização final de um grande período, todas as manifestações humanas ali contidas, da medicina ao direito, passando pelas ciências da natureza e pelas ciências sociais, tivessem que necessariamente conter em seu ventre as regras já definidas para caracterizar esses grandes períodos históricos. As séries históricas que vamos descrever serão narradas com certa independência da grande história.

A volta à questão da continuidade ou da descontinuidade na análise histórica, após o apelo ao sacrossanto nome do G. W. Hegel, tem apenas um objetivo, e esse é relativamente fácil de explicar: é importante definir um contra-ponto para esclarecer melhor a ulterior análise histórica sobre a evolução temporal dos registros de novos medicamentos nos Estados Unidos, e dos parâmetros de cientificidade da medicina contemporânea, que será empregada nesse trabalho. Há no método histórico hegeliano (Hegel, 2008) um aspecto que normalmente assume-se como verdade sem um questionamento prévio de se ele realmente é verdadeiro. Segundo Hegel, há uma razão no fluxo da história. A história é o autodesenvolvimento do espírito. No homem histórico concentram-se as potencialidades do seu tempo, mas ele é, a bem dizer, apenas uma fase no grande processo de desenvolvimento rumo à liberdade e a razão universal. Esse processo ocorre em direção à construção de sínteses progressivas. Assim como um astrônomo deve conhecer as leis da matemática e da geometria para aplicá-las ao conhecimento das estrelas, o historiador 
deve conhecer a dialética da Idéia para aplicá-la à história. O Homem Histórico, o material histórico do Espírito, é sempre imperfeito no momento de uma análise. O propósito último da análise histórica é 0 de aperfeiçoar continuamente esse Homem.

A idéia de um progresso contínuo na história direcionado pela Razão é extremamente poderosa. Em seu formato contemporâneo, ela remonta aos primeiros filósofos do iluminismo, porém em Hegel adquire um aspecto particular e quase material. Refiro-me à translocação do espaço da consciência, da auto-reflexão, para os espaços onde os progressos da Razão rumo à liberdade se manifestam em sua plenitude: o cristianismo, a filosofia e o Estado.

Essa translocação inspirou o universalismo dos românticos, e mudou o mundo. Kant já havia apontado para o papel da Razão rumo à liberdade (Kant, 2005; 2003), porém foi Hegel quem traçou os destinos da nossa auto-consciência histórica. Foi ele quem incorporou o indivíduo às leis da razão histórica, foi ele quem, ao se apropriar e desenvolver de forma radical a noção Fichtiana de tese $\mathrm{x}$ antítese $\mathrm{x}$ síntese, criou para a história uma espécie de método geral, ou lei geral, cujas conseqüências, além de universais, impregnam quase todo tipo de análise histórica realizada, da grande historia geral à história da medicina. Paradoxalmente, do seio de um pensamento essencialmente idealista, emergiram as mais fortes e poderosas concepções materialistas sobre 0 homem e suas realizações históricas, como o materialismo histórico de Marx e Engels.

Nessa forma de contar história, incluo a grande história da medicina e a história do registro de novos medicamentos. A história que até aqui contamos é aquela que, sob a influência do idealismo hegeliano, se encontra nos manuais e textos canônicos sobre 0 assunto. Seu caráter teleológico é evidente: o desenvolvimento da razão científica conduziu todo o processo rumo a um aprimoramento constante do processo legal e científico. As grandes tragédias (tese) conduziram a sociedade cristalizada na forma do Estado a produzir reações (antítese) que acabaram por construir uma nova realidade (síntese). 
Esta, em um novo e superior patamar, constitui-se, por sua vez, em nova tese, que sempre espreita seu antípoda rumo à realização do Espírito.

Tentaremos a partir de agora um novo caminho. Tentaremos abordar o mesmo problema de uma forma diferente. A análise de documentos sobre a questão da formação dos métodos comparativos em medicina clínica e sua relação com a legislação terá o sentido de verificar se a forma como a história canônica, conforme contada no capítulo anterior, descreve os fatos realmente explica o desenvolvimento da ciência médica conforme o gabarito de racionalidade que utilizamos hoje em dia.

$\mathrm{Na}$ seqüência vamos tentar dar um passo adiante na explicação do conceito histórico de razão. Vamos dar um passo extremamente arriscado no sentido de entender que a história não se realiza necessariamente no que Hegel chamava de Espírito, e que, talvez, dentro desse complexo conceito, oriundo da história da filosofia, outras razões são passíveis de compreensão e interpretação. Vamos, em particular, tentar utilizar a noção de racionalidade defendida pelo filósofo alemão Jürgen Habermas, sobretudo em sua obra maior "Teoria da Ação Comunicativa" (Habermas, 2003 a, b), a fim de tentar articular, no contexto histórico e social nos quais os fatos descritos ocorreram, uma explicação que seja historicamente conseqüente ou inteligível.

A maior dificuldade desse último projeto repousa no fato de ele ocorrer no contexto do entrecruzamento de dois poderosos pensamentos. De um lado a análise do poder empreendida por Michel Foucault, e que serviu como modelo de interpretação e descrição de fatos, por outro lado a análise habermasiana, que, partindo da Teoria dos Atos da Fala, constrói toda uma noção de racionalidade baseada no estabelecimento de relações interpessoais. As dificuldades desse entrecruzamento não se limitam apenas à falta de espaço onde todos os pontos de articulação ou de separação de ambos os pensamentos pudessem ser mais adequadamente confrontados $\mathrm{e}$ racionalizados. Há uma dificuldade inerente ao próprio projeto dessa articulação, que é o fato de que, ao proceder dessa forma, buscávamos uma espécie de compensação para as dificuldades epistemológicas de cada um dos 
pensamentos. Entretanto, penso que há um preço a pagar por essa ousadia. Esse preço é o fato de que a tentativa de reforço mútuo de duas fortes teorias explicativas de âmbito social pode acabar por provocar um enfraquecimento proporcional de seus caracteres de precisão e decidibilidade. Espero de alguma forma conseguir suplantar essa dificuldade, ou pelo menos deixar claro onde elas se manifestam.

A narrativa que se seguirá ocorrerá por aproximação progressiva. Vai partir do geral em direção ao específico. Ela será dividida em três grandes partes. A primeira parte inicia com o ambiente econômico das nações ocidentais a partir da década de quarenta, com um foco particular nas décadas de sessenta e setenta. Veremos que a noção política de liberdade era extremamente importante nesse período, e que em torno dela mais de uma proposta de como se governar surgiu no mundo. Essa abordagem nos conduzirá à história do neoliberalismo. Veremos a seguir como essa abordagem de natureza política e econômica se correlacionava intimamente com a escola filosófica norteamericana denominada de pragmatismo, e, por último, veremos como esse pragmatismo foi o principal articulador ideológico que conduziu o processo de registro de novas drogas nos Estados Unidos. Essa última parte seguirá um caminho um pouco mais demorado, porque, para proceder a essa demonstração, achei por bem articular a correlação proposta em três níveis, que denominei de: relações biográficas, relações relacionadas à crise econômica e finalmente relações entre o utilitarismo inglês e o pragmatismo americano. Esse cuidado de uma prova mais cabal da relação entre o pragmatismo e o registro de novas drogas tem um duplo objetivo: 1) preparar o terreno para compreender os caminhos trilhados para as tomadas de decisão posteriores no que tange a aspectos práticos (científicos e legais) do registro de novas drogas e, 2) preparar o terreno para entender como fizemos a leitura de uma noção de humanismo um pouco distinta e deslocada da literatura corrente sobre o assunto na medicina brasileira.

Na segunda parte, partiremos da descrição da emenda Kefauver-Harris em maiores detalhes, em seguida abordaremos as relações institucionais entre 0 FDA e o Poder Legislativo americano, e, logo depois, faremos uma primeira 
abordagem sobre a racionalidade dos critérios científicos sobre eficácia terapêutica, e esta será seguida por uma descrição mais aprofundada sobre a questão da cientificidade dos dados empíricos. Toda essa discussão levará ao que denomino como "a questão principal", que circula em torno da lei de patentes no mercado farmacêutico. Por último, faço uma descrição pormenorizada a respeito das barreiras que existem em torno da manutenção e defesa da lei de patentes e, concluo, com a legitimação de todo esse processo na sociedade, em particular da nova racionalidade científica médica que emergiu nessa época.

Essa última discussão abrirá portas para a terceira parte que é a discussão a respeito da relevância de toda essas informações para o processo de humanização da medicina contemporânea. 
Parte II - O ambiente histórico 


\section{O ambiente econômico e político das décadas de sessenta e setenta}

As décadas de 60 e 70 têm mais a dizer do ponto de vista histórico do que as profundas revoluções dos costumes e hábitos das sociedades industrializadas ocidentais. Não é apenas a luta pelos direitos civis nos Estados Unidos, a livre expressão da juventude universitária européia e a busca por uma sociedade mais igualitária na América Latina que marcaram indelevelmente esses conturbados e interessantes anos. Na mesma época outra revolução, esta mais silenciosa, porém, talvez, mais determinante para o futuro dos países, de fato ocorreu. Refiro-me à reestruturação do liberalismo econômico clássico, sob a égide teórica do neoliberalismo. A relevância dessa discussão para o objeto desse estudo repousa no fato de que a estrutura regulatória para registro de novos medicamentos nos Estados Unidos ocorreu em paralelo à instituição das regras neoliberais de governar naquele país. Não pretendo fazer uma descrição exaustiva do neoliberalismo, nem me considero em condições técnicas para isso, o que quero é apontar para o fato histórico de que essa forma de gerir a sociedade tem um diferencial prático em relação ao liberalismo tradicional, particularmente no que se refere à construção de regras previamente estabelecidas e legalmente aprovadas através dos marcos regulatórios do exercício da liberdade econômica.

Nenhum modo de pensamento se torna dominante sem propor um aparato conceitual que mobilize nossas sensações, nossos valores e até nossos desejos. Esse aparato, para vingar como verdade estabelecida, tem que construir possibilidades para o mundo em que vivemos. Além disso, quando bem sucedido, ele se incorpora a tal ponto ao senso comum que passa a ser tido por certo e livre de qualquer possibilidade de questionamento. No caso do neoliberalismo a palavra que melhor define esse aparato conceitual é: liberdade. Essa é uma palavra que comove, mobiliza.

Quando se pensa em definir o neoliberalismo, ou quando a grande imprensa trata do assunto, normalmente três aspectos vêm imediatamente a nossa 
mente: do ponto de vista econômico, a construção de um espaço livre, onde o mercado seria o direcionador dos processos de trocas e o alicerce da complexa noção de valor; do ponto de vista sociológico pensa-se na noção de que as regras sociais seguem determinantes predominantemente, se não exclusivamente, de caráter mercantil; e, finalmente, do ponto de vista político, ou geopolítico, de que as fronteiras entre os Estados foram extintas em nome de uma livre circulação das moedas dos serviços e dos produtos. É a famosa globalização (Harvey, 2008).

Há, a bem dizer, uma tendência a ver no neoliberalismo uma continuação do liberalismo clássico. Adam Smith falando sobre a "mão invisível do mercado", John Stuart Mill redefinindo o conceito de "utilidade", ancorado nos economistas políticos clássicos, e discorrendo sobre o valor do utilitarismo individual no crescimento da sociedade como um todo (voltarei a esse ponto em outra parte desse trabalho). Entretanto, uma análise histórica mais acurada mostra que, não só os princípios do neoliberalismo têm particularidades distintas do liberalismo tradicional, como sua aplicação na prática que se cristalizou particularmente a partir da década de sessenta nos países centrais, como ocorreu sob alicerces bastante diferentes da instituição do Liberalismo no séculos XIX e sua grande crise no século XX. E que alicerces são esses?

Ser liberal não é, em absoluto, ser conservador, no sentido de lutar pela manutenção de privilégios obtidos em legislações passadas. Ser liberal, ao contrário, é ser essencialmente progressista no sentido de uma perpétua adaptação da ordem legal às descobertas científicas, aos progressos da organização e da técnica econômicas, às mudanças de estrutura da sociedade, às exigências da consciência contemporânea. Ser liberal não é deixar os carros trafegarem em todos os sentidos, a seu bel-prazer, do qual resultariam engarrafamentos e acidentes incessantes. Não é como para os adeptos do planismo, estabelecer para cada carro sua hora de saída e seu itinerário. Ser liberal é impor um Código de Trânsito, admitindo que ele não é exatamente e necessariamente o mesmo na época dos transportes acelerados e na época das diligências. Uma economia verdadeiramente liberal é uma economia que se submete a uma dupla arbitragem: à arbitragem espontânea dos 
consumidores que partilham os bens e os serviços que thes são oferecidos no mercado ao sabor de suas conveniências e pelo plebiscito dos preços, e, por outro lado, à arbitragem concertada pelo Estado, que assegura a liberdade, a lealdade e a eficiência do mercado (Harvey, 2008).

Isso quer dizer o seguinte: o que caracteriza o nosso tempo, na prática, pelo menos desde os anos sessenta, não é exatamente a supremacia de um mercado livre e arbitrado pelas leis econômicas imutáveis, às quais todos devemos nos submeter assim como nos "submetemos" às leis da física. Essa era a utopia dos fisiocratas. Apesar de alguns pontos em comum, estamos longe disso. O que de fato caracteriza nossa sociedade do ponto de vista das relações de troca é, acima de tudo, a construção de um arcabouço institucional extremamente complexo, multifacetado, poliédrico, onde vários discursos, alguns mesmo antagônicos entre si, acabam por construir um quadro cuja visão à distância parece ter uma regularidade nem sempre fácil de vislumbrar quando nos aproximamos de seus detalhes, quando o percebemos fenomenologicamente (Foucault, 2008). Há, nesse contexto, três discursos que serão analisados para se tentar uma aproximação da legitimação da ciência médica contemporânea: os aspectos econômicos, os aspectos jurídicos e finalmente os aspectos das regras internas da ciência médica. Defendo que essa separação é apenas acadêmica e didática, defendo que a relação entre esses discursos não é meramente uma relação de causa e efeito.

Outro ponto que tem que ser esclarecido à luz do método de análise que estamos empreendendo é a relação entre o econômico e o jurídico. Isso é extremamente importante para que mal-entendidos não ocorram. Quero desde já deixar claro que não pretendo dizer, com as histórias que serão descritas nos capítulos posteriores, que os interesses das empresas farmacêuticas determinaram o arcabouço jurídico/legislativo que regula os registros de novas drogas. Tão pouco pretendo dizer que são esses mesmos interesses que direcionam a ordem científica da medicina contemporânea. Uma interpretação nesse sentido seria uma grande decepção para o autor, que, na verdade, pretende fugir dessa linearidade enganadora. A relação que se pretende estabelecer entre a estrutura legislativa e a ordem econômica, não é a relação 
clássica entre superestrutura por um lado e infra-estrutura por outro. Não se trata de imaginar que as leis que foram criadas para garantir a segurança da população com relação aos novos medicamentos lançados no mercado tinham um caráter de subordinação, ou de instrumentalidade, com relação aos interesses econômicos, ou que refletiam em nome da liberdade individual os direitos inalienáveis dessa mesma população. O que se defende, ao contrário, é que os aspectos jurídicos, econômicos e científicos se enformam uns nos outros. Trata-se da existência de uma ordem econômico-jurídica que se quer defender. À moda do grande Max Weber, trata-se de entender o registro de novos medicamentos, em todos os seus aspectos (históricos, científicos, sociais, jurídicos, acadêmicos, etc...), não no nível das forças de produção, mas no nível das relações de produção (Weber, 2006b; 2006c). Isso implica em pensar esse problema de uma forma um pouco mais complexa do que imaginar os dois cenários mais permeáveis ao entendimento imediato. $\mathrm{O}$ primeiro seria 0 econômico determinando o arcabouço jurídico regulatório, e, o segundo, mais espinhoso de tratar (mas não nos furtaremos a ele), seria o de considerar que é a racionalidade científica que sobredetermina tanto a ordem econômica quanto a jurídica. Nesse ponto, penso, devemos voltar à questão da história do neoliberalismo e como ela se encaixa na análise da cientificidade do discurso médico contemporâneo.

Até agora defendemos que uma das características mais marcantes do neoliberalismo, talvez a mais importante, seja que o Estado econômico deve assumir a responsabilidade de construir um arcabouço institucional que garanta, efetivamente, que as regras do mercado possam operar de maneira livre e desimpedida. Defendemos, também, que essas regras de mercado pressupõem, necessariamente, e desde o início, não a idéia de que as leis de mercado têm um caráter natural, mas, ao contrário, que são essencialmente uma atividade que tem que ser regulada (Foucault, 2008). A conseqüência prática que queremos apontar é de que no que tange à história recente da cientificidade da medicina e sua atual forma cristalizada, devemos considerar que, tanto os aspectos técnicos, quanto os institucionais, quanto os econômicos e jurídicos, todos esses aspectos (e talvez outros que nos escapam) devem ser analisados sincreticamente, uma vez que, historicamente 
eles se apoiaram e se modificaram mutuamente. Eles se modelaram numa reciprocidade incessante que terminaram por definir o que hoje chamamos genericamente de Ciência Médica. 


\section{A história do Neoliberalismo}

A reestruturação das formas de Estado e das relações internacionais depois da Segunda Guerra Mundial pretendia impedir um retorno às condições catastróficas que se seguiram à crise dos anos trinta e às condições geopolíticas que culminaram com o conflito armado mundial. Foi preciso assegurar a paz e a tranqüilidade domésticas e, ao mesmo tempo, firmar algum tipo de acordo entre o capital e o trabalho. A impressão geral no período pósguerra era de que as três grandes ideologias, a saber: o capitalismo, 0 socialismo e o fascismo tinham falhado em suas intenções iniciais, que era preciso construir uma nova e correta combinação entre Estado, mercado e instituições democráticas que fosse capaz de garantir a paz, a inclusão, o bemestar e a estabilidade (Bobbit, 2003).

Uma nova ordem internacional, construída com os acordos de Bretton Woods, e a criação de várias instituições, como a Organização das Nações Unidas, o Banco Mundial, o Fundo Monetário Internacional, entre outras, construiu condições para se formular uma nova forma de estabilizar as relações políticas e econômicas mundiais. O livre comércio de bens foi incentivado sob um sistema de câmbio fixo escorado na convertibilidade do dólar norte-americano em ouro a um preço fixo. Esse sistema era incompatível com os livres fluxos de capital que fazem parte do sistema de trocas, mas os Estados Unidos tiveram que permitir o livre fluxo da sua moeda, o dólar, para além das suas fronteiras, para que este funcionasse como a moeda de reserva global.

Uma das conseqüências políticas desse cenário foi que vários Estados com características dirigistas emergiram no mundo todo. $O$ que esses Estados tinham em comum era a aceitação do fato de que o Estado deveria se concentrar no pleno emprego, no crescimento econômico e no bem estar de seus cidadãos, e de que o poder do Estado deveria ser livremente distribuído ao lado dos processos de mercado (eventualmente intervindo ou substituindo 
esses processos), para se assegurar a consecução desses objetivos. Políticas fiscais e monetárias foram elaboradas e implementadas para que esse sistema funcionasse. O conjunto dessas políticas chamava-se de keynesianismo, em homenagem a Lord John Maynard Keynes, um dos principais mentores intelectuais desse processo. Essa forma de organização política e econômica tinha como uma das suas características principais a construção de um ambiente regulatório cujo objetivo era modular a atividade econômica de uma sociedade, às vezes incentivando, outras vezes restringindo, a ação do agente econômico. O conjunto das regras regulatórias configuraria um sistema de planejamento central da produção econômica de um país, e este deveria ser subordinado aos interesses coletivos. Como veremos, mesmo os Estados Unidos praticaram esse tipo de arte de governar.

$\mathrm{Na}$ prática, esse sistema produziu elevadas taxas de crescimento nos países centrais, apesar da maioria do mundo não ter se beneficiado tanto desse sistema. Entretanto, perto do final dos anos sessenta, esse sistema todo começou a ruir, tanto internacionalmente, quanto nas economias individuais de cada país. Os sinais de uma grave crise econômica de acumulação eram aparentes em todas as partes. O desemprego e a inflação se ampliaram por quase todos os países, desencadeando uma fase global de estagflação que duraria por praticamente toda a década de setenta. Graves crises fiscais ocorreram em vários países, decorrentes de uma diminuição da arrecadação e um aumento dos gastos em políticas sociais. Em paralelo a isso, ocorreu o embargo do petróleo em decorrência da guerra árabe-israelense. $O$ keynesianismo não mais funcionava. O sistema de taxas de cambio fixo baseado em reservas de ouro, tinha se mostrado ineficaz. A porosidade das fronteiras dos Estados em relação ao fluxo de capitais desarmara todo o sistema de trocas entre os países. O keynesianismo, que gerara altas taxas de crescimento após 1945, estava claramente esgotado e deixara de funcionar (Kissinger, 1993).

Uma grave crise econômica estava instalada no mundo. A superação dessa crise requeria alguma alternativa. É nesse enquadramento histórico que vamos descrever a história da regulamentação de novos medicamentos nos EUA, mas 
antes vamos entender melhor o fundamento teórico dessa alternativa. O que exatamente é o neoliberalismo?

Curiosamente, um país do nosso continente, o Chile, foi uma espécie de laboratório inicial do neoliberalismo. A crise econômica que se instalara nos países desenvolvidos teve também importantes conseqüências nos países pobres. Na América Latina, em particular, que, desde a década de cinqüenta, vinha fundamentando todo seu modelo de crescimento econômico nas chamadas políticas de substituição de importações, viu esse modelo se desarticular em função da falta de investimentos externos em produção. No Chile as coisas assumiram uma proporção social particularmente dramática, sobretudo devido à gravíssima crise político-institucional que se seguiu ao golpe de estado que depôs o Presidente Allende.

Para dar conta dessa terrível crise, um grupo de economistas, conhecidos como "Chicago Boys", devido à sua adesão à teoria econômica de Milton Friedman, então professor da Universidade de Chicago, foi chamado para ajudar no processo de reconstrução da economia chilena. Após acertar um considerável empréstimo com o Fundo Monetário Internacional, esse grupo reestruturou toda a economia chilena, e tomou como principais medidas: 1) a privatização dos ativos públicos, 2) a liberação da exploração dos recursos naturais à exploração privada com mínima intervenção reguladora por parte do Estado (excetuando-se o cobre, que funcionava como um avalista do processo), 3) a facilitação de investimentos diretos de empresas estrangeiras e garantia institucional de repatriação dos seus lucros, entre outras atividades que visavam construir o primado da livre concorrência em detrimento de qualquer tipo de planificação central. A conseqüência de todo esse processo foi que o crescimento liderado pelas exportações passou a prevalecer sobre o processo anterior de substituição das importações. Esse sistema funcionou bem até o início dos anos oitenta quando, uma grave crise relacionada à dívida externa, que, na realidade assolou toda a América Latina, fez o processo todo retroceder. 
A experiência chilena de reestruturação de sua economia, baseada nos princípios de desregulamentação da economia e incentivo a uma prática baseada exclusivamente na concorrência dos agentes econômicos, e que teve como principal mentor o economista da Universidade de Chicago, o Prof. Milton Friedman, foi o alicerce histórico sobre o qual os principais personagens do neoliberalismo mundial, o Presidente americano Ronald Reagan, e a Primeira Ministra Inglesa, Margareth Thatcher (sobre quem falaremos com maiores detalhes quando especificarmos melhor nosso tema), construíram sua nova arte de governar baseada nos princípios do neoliberalismo (Harvey, 2008).

Do ponto de vista teórico, as diretrizes da arte de governar neoliberal podem certamente remontar a períodos anteriores ao que descrevemos nos parágrafos acima. Em seções posteriores vamos aprofundar ainda um pouco mais esse tema com o objetivo de demonstrar mais nitidamente que há uma relação direta entre a solução de crises relacionadas à ciência médica nas décadas de sessenta e setenta e o neoliberalismo europeu, particularmente de origem alemã. $\mathrm{O}$ objetivo disso tudo é compor um quadro histórico que explique como se formou um novo saber médico, como se constitui a medicina científica contemporânea.

Em 1947, um seleto grupo de intelectuais reuniu-se no paraíso dos Alpes, numa pequena localidade denominada Mont Pelerin, na Suiça, para discutir um possível antídoto para a então conturbada ordem social do sistema capitalista e para as mazelas que o grupo vislumbrava que poderiam advir das políticas públicas que se pensava em implementar. Esse grupo se reuniu em torno do economista austríaco Friedrich Von Hayek, e era constituído por eminentes pensadores como Karl Popper, o economista americano Milton Friedman, e personalidades históricas do porte de Ludwig Von Mises, sobre quem falaremos brevemente depois. Esse encontro fundou a Sociedade de Mont Pelerin, que existe ainda hoje. Par se ter uma noção do seu significado nesse processo penso que vale a pena ler uma tradução da Declaração de Fundação dessa sociedade: 
"Os valores centrais da civilização se acham em perigo. Em grandes extensões da superfície da terra as condições essenciais da dignidade e da liberdade humanas já desapareceram. Noutras acham-se sob constante ameaça do desenvolvimento das atuais tendências políticas. A posição do indivíduo e o grupo autônomo se acham solapados por avanços do poder arbitrário. Mesmo o mais precioso bem do Homem Ocidental, a liberdade de pensamento e de reflexão, encontra-se ameaçado pela disseminação de credos que, reivindicando o privilégio da tolerância quando em posição minoritária, buscam apenas galgar uma posição de poder a partir da qual possam suprimir e obliterar todas as concepções que não a sua".

"O grupo sustenta que esses desenvolvimentos vêm sendo promovidos pela ascensão de uma concepção de história que nega todos os padrões morais absolutos e de teorias que questionam o caráter desejável do regime de direito. Ele sustenta ainda que esses desenvolvimentos vêm sendo promovidos por um declínio na crença da propriedade privada e no mercado competitivo; porque, sem o poder e a iniciativa difusos associados a essas instituições, torna-se difícil imaginar uma sociedade em que se possa efetivamente preservar a liberdade" (Harvey, 2008).

Esse grupo se dizia "liberal" no sentido europeu tradicional, devido a seu compromisso fundamental com ideais de liberdade pessoal. O rótulo neoliberal marcava sua adesão aos princípios de livre mercado da economia neoclássica que emergira na segunda metade do século XIX, e cujos economistas pensadores mais renomados são Alfred Marshall e Leon Walras. $O$ pensamento desses grandes economistas veio para de alguma forma substituir, ou incrementar, as teorias clássicas de Adam Smith, David Ricardo, e seu mais feroz crítico, Karl Marx. Apesar de alinhados com a economia neoclássica, não abriam mão de pensar, como o filósofo moralista escocês, Adam Smith, que a mão invisível do mercado constituía o melhor recurso de mobilização de mesmo os mais vis instintos humanos, como a gula, a ambição e o desejo de riqueza e poder. 
Em resumo, a doutrina neoliberal opunha-se profundamente às teorias do Estado intervencionista como a de John Maynard Keynes, que haviam alcançado proeminência nos anos 1930 em resposta à Grande Depressão e que haviam sido amplamente colocadas em prática após a Segunda Grande Guerra, como vimos acima. Os neoliberais mostravam-se particularmente contrários a qualquer teoria de planejamento central. Este, pode-se dizer, era seu principal inimigo teórico e prático. Hayek, em seu famoso livro "The Road to Serfdom" (Hayek, 2007), que analisaremos em um pouco mais de detalhes adiante, diz que a batalha de idéias entre as teorias econômicas era fundamental e inevitável, mas que ela não duraria mais do que uma geração para ser ganha pelo liberalismo, e que essa vitória não seria apenas em cima do marxismo, mas também em cima do planejamento central do Estado e do intervencionismo keynesiano.

Veremos adiante que o prognóstico do Prof. Hayek não estava de todo incorreto. Sua doutrina, ou a doutrina que ele representava, foi totalmente incorporada ao pensamento político e econômico dos anos setenta e oitenta. Usaremos a história da regulamentação de novos medicamentos para tentar demonstrar essa assertiva e, esperamos mostrar no final desse texto, que esse pensamento constitui a base ideológica em cima da qual se construiu 0 conceito contemporâneo de ciência médica.

Há mais um ponto de articulação histórica das origens do neoliberalismo que nos interessa. Trata-se de relacionar essa forma de pensamento econômico com o período logo após a derrota do nazismo na Alemanha. A Alemanha vinha de uma longa história de planificação estatal que remontava ao tempo da unificação do Estado Alemão no Século XIX, com Bismarck. A derrocada do nazismo foi, sob a perspectiva da história do pensamento econômico do século $X X$, um pouco mais do que o fim da tirania hitlerista. Foi a destruição de uma forma de governar (Foucault, $2008 \mathrm{a}, \mathrm{b}$ ).

Vimos que o que caracterizou o rumo da economia mundial logo após a Segunda Guerra, na maioria dos países do mundo, foi um processo de reconstrução, baseado na planificação e na socialização de alguns objetivos 
sociais. Vimos que isso significava uma busca de política de pleno emprego, de equilíbrio de preços, do nível de poupança, enfim, uma política de intervenção do Estado na alocação dos recursos disponíveis em uma sociedade. Mas, e na Alemanha, onde esse tipo de intervenção do Estado já fazia parte da sua história, como se deu esse processo? Por que isso é importante para nossa história?

Na mesma época em que o grupo de Mont Pelerin se reunia na Suíça, a Alemanha, derrotada na guerra, também precisava se recompor. Acontece que as bases ideológicas e técnicas que conduziram essa reconstrução foram bastante diferentes do que acontecia no resto do mundo. Em 1948, quando a administração do Estado Alemão estava sob a responsabilidade dos Estados Unidos e da Inglaterra, um Conselho Científico foi nomeado para estudar o problema econômico do país e sugerir soluções para o futuro. A conclusão desse conselho foi de que a direção do processo econômico deveria ser assegurada o mais amplamente possível pelo mecanismo de preços livres. Esse conselho tinha função apenas consultiva, mas a menção de sua conclusão já aponta para direções diferentes do que o resto do mundo estava tomando.

Se o Conselho Científico tinha apenas ação consultiva, o administrador da Alemanha ocupada, Ludwig Erhard, tinha poderes executivos reais. Poucos dias depois da publicação do relatório do Conselho, o Sr. Ludwig Erhard fez uma assembléia na cidade de Frankfurt na qual reitera e apóia as conclusões do Conselho, no sentido de solicitar a liberação imediata de todos os preços que estavam sob o controle do Estado. Ele diz que era preciso libertar a economia de todas as injunções estatais, que as fronteiras e os limites da estatização deveriam ser fixados, e que as relações entre os indivíduos e 0 Estado deveriam ser regulamentadas. A partir de 1948 houve um processo progressivo de liberação de todo tipo de controle estatal sobre os preços na Alemanha, começando pelos preços industriais, seguido dos preços dos alimentos, até finalmente chegar aos preços do carvão e da eletricidade (Foucault, 2008a). Claro que a complexidade da reconstrução econômica da Alemanha não pode ser resumida nesse pequeno exemplo. Sua citação tem o 
objetivo de apontar para três aspectos que darão sustentação a argumentação posterior.

O primeiro aspecto refere-se a questão já citada de que a Alemanha cursava um caminho de política econômica e de orientação ideológica de alguma forma diferente do resto do mundo. O segundo é que, para a implantação desse processo de uma forma consensual na sociedade alemã, um interessante pressuposto básico teve que ser atendido. Esse pressuposto é o de que o Estado nazista, com todas suas práticas de controle da sociedade e da economia, não tinha legitimidade. Essa legitimidade se perdera, não só pela derrota nas armas, mas, principalmente, pelo fato de que, por ser a Alemanha um Estado que não garantia as liberdades econômicas para sua população, esse Estado carecia de uma legitimidade jurídica que o garantisse. $\mathrm{Na}$ realidade o papel do administrador deveria ser construir uma moldura institucional, caracterizada particularmente pela liberdade do agente econômico, garantida pelo instituto da lei, e que permitisse a livre concorrência no seio da sociedade. O terceiro e último aspecto é que os membros desse conselho eram exatamente as mesmas pessoas que depois influenciaram toda a doutrina econômica desenhada pela Escola de Economia da Universidade de Chicago, como veremos em maiores detalhes nos parágrafos abaixo. 


\section{Uma nova forma de governar: Garantir as regras da concorrência.}

Então vimos que a Alemanha no pós-guerra tinha uma situação particular em relação aos outros países que buscavam se reconstruir. A questão fundamental e diferencial era que o Estado alemão simplesmente tinha deixado de existir. Sua legitimidade histórica havia sido questionada pelos próprios alemães sob a argumentação de que os fundamentos históricos desse Estado não representavam o povo alemão em sua liberdade de escolha. Vimos também que quem capitaneou esse processo do ponto de vista político teve um aconselhamento técnico por parte de um comitê que recomendava, na contramão do que estava acontecendo em quase todos os outros países do mundo, uma orientação econômica do tipo não intervencionista, com liberação total de todos os preços e com uma muito restrita planificação central.

Agora, de onde surgiu esse comitê científico? O que o caracterizava? Quais seus fundamentos ideológicos? E, principalmente, o que o diferenciava do Estado Liberal advogado pelos economistas clássicos, e que era praticado pelas principais nações ocidentais até aquele momento?

A análise empreendida por Michel Foucault em um de seus últimos cursos (Foucault, 2008a), um material interessantíssimo que nunca chegou a ser publicado em formato que não de transcrição, parte de uma premissa extremamente importante e que será utilizada como base de análise do sistema de regulação de medicamentos nas décadas de sessenta e setenta. Essa arrogância (ou coragem) encontra respaldo na obra do próprio autor, que ativamente incitava a posteridade a buscar histórias, desenhar genealogias. Além disso, e talvez mais importante do que o legado do autor, deve-se registrar o fato de que, desde a realização desse curso até os dias de hoje, uma nova configuração geopolítica está ocorrendo no mundo, e muitas percepções que, na época, foram discutidas podem hoje em dia ser revisitadas. 
A questão principal que aqui se coloca é demonstrar que o liberalismo alemão do pós-guerra não era exatamente uma continuação do liberalismo tradicional. Ainda que compartilhasse alguns dos seus princípios, em particular: 1) a racionalidade dos agentes econômicos, 2) o usufruto da liberdade que se define tanto pela autonomia do empreendedor em relação à coerção do Estado, mas, principalmente pela liberdade da contratação da força de trabalho fora do sistema pouco produtivo da servidão e da escravidão, 3) e principalmente pelos preceitos do utilitarismo, ou moral utilitarista, que pressupõe o fato de que o enriquecimento de uma nação necessariamente significa a melhora de vida individual de cada um de seus componentes. Agrega-se a esses três princípios, o fato de que cabe à organização legal de uma sociedade montada sobre as bases do liberalismo a prerrogativa de determinar os limites de ação dos indivíduos, de uma forma que a ação individual não comprometa as necessidades da coletividade.

Esses são os pontos em comum. Há, contudo, dois pontos que representam uma verdadeira ruptura em relação ao liberalismo tradicional. Vamos ver quais são eles:

A primeira, e mais importante diferença para defesa de nossos objetivos é que, no neoliberalismo, o problema não é mais, como no caso do liberalismo clássico, saber como se pode regular o exercício geral do poder com base nos princípios gerais do livre mercado, ou de uma economia de mercado. Não se trata, para o neoliberalismo, de abrir um espaço onde os agentes econômicos possam exercer sua liberdade contra as restrições ou amarras históricas impostas pelo poder do soberano. O que se tem que fazer a partir dessa nova forma de ver o mundo econômico é construir regras que sejam claras e previsíveis, e que essas regras representem um consenso entre todos os agentes interessados e envolvidos. A questão se desloca em relação ao liberalismo tradicional na direção de permitir a construção de um novo espaço para a arte geral de governar através de técnicas que criem condições de existência de uma economia exclusivamente direcionada para o mercado concorrencial. 
A segunda diferença refere-se ao conceito de concorrência, e às formas práticas de agir sobre as relações concorrenciais. No liberalismo clássico, a concorrência era considerada um dado primitivo e natural, presente de forma estrutural nos fundamentos da sociedade. Se se deixasse essa estrutura aflorar, se se the permitisse vir à superfície, ela mesma, por seus mecanismos intrínsecos, trataria de assegurar a ordem econômica pelo mecanismo competitivo dos preços (Landes, 1998). Os idealizadores no neoliberalismo alemão, que, como veremos adiante, iniciaram sua atividade teórica não no pós-guerra dos anos quarenta, mas após a Primeira Guerra Mundial, sabiam ou já tinham vivido o suficiente sob a égide do liberalismo clássico para saber que não era exatamente assim que as coisas deveriam ser reorganizadas.

A idéia era de que a auto-regulação pela estrutura natural da concorrência já se mostrara insuficiente para que o princípio inalienável da liberdade de ação do empreendedor fosse preservado. As múltiplas crises e as várias e sangrentas guerras que o ocidente vivera impunham uma nova forma de se pensar a idéia, ou o conceito, de concorrência. Era preciso voltar aos fatos eles mesmos! Era preciso interrogar a consciência! Era uma questão para a fenomenologia ajudar a responder. Voltaremos a esse ponto mais tarde. Por enquanto, para fecharmos essa questão da concorrência, importa dizer que, para os neoliberais alemães, a concorrência deveria estar sob o signo de uma vigilância permanente e de um processo de intervenção, que deveria se manifestar sob a forma dos agentes econômicos exercerem ativamente sua necessária liberdade de ação. Tratava-se de um processo ativo.

Foucault disseca um texto denominado "Colóquio Walter Lippman", que, segundo o filósofo, é uma espécie de resumo do que foi de fato executado no Alemanha do pós-guerra. Participaram desse colóquio, cujo objetivo era justamente discutir os rumos da economia liberal européia, e que gerou uma interessante comissão denominada "Comissão Internacional de Estudo para Renovação do Liberalismo", economistas de linhagem liberal tradicional, figuras paradigmáticas como Von Miess e Hayek. Falaremos muito mais sobre eles, sobretudo sobre Hayek, mais tarde. Um dos importantes participantes desse colóquio, o economista alemão Röpke, figura política que, segundo Foucault, 
mais tarde será extremamente importante no processo de reconstrução econômica da Alemanha pós-guerra, diz em texto posteriormente publicado: "A liberdade de mercado necessita de uma política ativa e extremamente vigilante" (Foucault, 2008 a).

Em resumo: para o neoliberalismo, a posição tradicional de o Estado Liberal procurar saber onde se deve ou não intervir na economia, dependendo dos vetores resultantes da prática natural da concorrência, é, a bem dizer, uma posição ingênua. Para a nova ordem liberal o que importa é saber como intervir. O problema fundamental é fazer a intervenção de uma forma que não parta de um principio natural, mas que represente um consenso sob a égide (e em função) do exercício da liberdade.

Para introduzir ao que se quer dizer com a palavra intervenção, no sentido neoliberal, penso que ajudaria entender como essa corrente de pensamento interpreta o fenômeno do monopólio numa economia liberal e capitalista. Essa breve análise de certa forma começará a nos situar na questão específica da regulamentação de novos medicamentos, uma vez que, como discutiremos largamente posteriormente, a proteção por patente no mercado terapêutico se configura como um caso típico de monopólio, e que a sua defesa contém a força motriz de todo o processo de regulação que ocorreu nos anos sessenta e setenta. Para mim, trata-se da questão fundamental de toda essa discussão.

Apesar da questão do monopólio ser muito importante na defesa argumentação desse trabalho, a descrição de seus aspectos técnicos e políticos somente será realizada em outra parte. Nesse momento, importa continuar a descrição histórica de como os neoliberais alemães interpretavam esse aspecto do sistema produtivo. Para a tradição da economia política clássica, o monopólio é uma tendência natural e até necessária de um sistema competitivo. Ou seja, não se pode deixar o sistema de livre concorrência se desenvolver sem que apareçam, ao mesmo tempo, fenômenos monopolísticos que têm, precisamente, o efeito de limitar, ou até mesmo anular, a própria concorrência. Faz parte, portanto, da própria lógica interna do sistema liberal da livre concorrência que os meios de produção se articulem de tal forma, seja 
reduzindo custos ou atuando em regime de grandes escalas produtivas, ou ainda através de fusões e incorporações entre grandes empresas, que acabem por eliminar o próprio sistema de concorrência. Trata-se de uma contradição interna do sistema capitalista liberal que não somente o explica, como, até mesmo, o constitui em sua essência.

Acontece que, segundo os clássicos, há que se intervir sobre essa tendência inexorável das forças produtivas, com o objetivo de se regular o mercado. Essa intervenção dá-se, via de regra, na chamada superestrutura jurídica. Em outras palavras mais simples: se se quer salvar o sistema de livre concorrência de seus próprios efeitos destrutivos, há que se intervir, em alguns casos, no próprio sistema econômico, restringindo a possibilidade de práticas de monopólio.

Curiosamente, essa forma de analisar o monopólio é compartilhada tanto pelos liberais clássicos quanto pela tradição de economistas e sociólogos marxistas. Ambos consideram que as chamadas "forças produtivas" conduzem os processos de inter-relação entre os homens e os seus modos de produção em uma sociedade. Mas, em contra-ponto, já que é isso que estamos analisando, como o neoliberalismo alemão explicava o fenômeno do monopólio?

Max Weber, na antológica obra "A Ética Protestante e o Espírito do Capitalismo" (Weber, 2004), assim como em outros textos menos paradigmáticos (Weber, 2006 b), abre uma verdadeira fenda nessa forma de pensar a economia política e o problema do monopólio. Para o sociólogo alemão, as relações de produção deveriam ter primazia de análise sobre as forças produtivas. A ética dos protestantes fez mais, segundo esse autor, pelo desenvolvimento do sistema capitalista do que a dialética histórica das contradições entre capital e trabalho.

Em outra obra de enorme envergadura intelectual (Weber, 2006 a), Weber demonstra como os primeiros empreendimentos verdadeiramente capitalistas, como as viagens para o oriente, ou as descobertas marítimas, foram empreendimentos patrocinados de maneira monopolista e sob a proteção 
jurídica dos Estados. Cabia ao príncipe, ao soberano, garantir o arcabouço institucional da aventura capitalista em sua alvorada mercantilista. Em que pese diferenças importantes entre os países do norte e do sul da Europa, a busca de novos mercados contava como o suporte institucional e estatal que Ihe deu o aval e o apoio. Há na mesma obra alguns outros exemplos que apontam para a conclusão de que as relações de produção, em fórmula inversa às tradições liberal e marxista, determinam o desenvolvimento econômico. Portanto, para Max Weber, o monopólio não era própria ou necessariamente, uma decorrência histórica do processo natural de competição, mas era, ele mesmo, uma estrutura constituinte da formação do próprio sistema. A título de ilustração, é bom que se diga que, havia para Weber uma razão para isso, quero dizer, havia uma razão para o príncipe garantir amparo legal e institucional para o empreendimento capitalista nascente. Essa razão se encontrava na construção de uma máquina fiscal que fosse eficiente 0 suficiente para garantir a formação e ao mesmo tempo amalgamar o poder do seu próprio Estado.

O Comitê Científico ao qual nos referimos anteriormente, e que deu suporte técnico à política de reconstrução da Alemanha no pós-guerra, tinha, evidentemente, um presidente. Seu nome era Walter Euken. Euken era um brilhante economista que tinha sido discípulo, no início do século XX, de Alfred Weber, irmão e defensor voraz da obra do seu irmão sociólogo. Além dessa pequena coincidência biográfica, há uma outra que, a meu ver, merece certo destaque em deferência à história das idéias. Essas articulações podem, talvez, servir para explicar algumas coisas.

Euken formou-se em economia na Faculdade de Friburg e lá travou conhecimento com ninguém menos do que Edmund Husserl, eminente fundador da fenomenologia, sistema de pensamento de incalculável influência ao longo de todo século XX. Desse contato pode-se derivar duas importantes conseqüências para nossa argumentação: Em primeiro lugar, e fechando 0 assunto que havíamos deixado em aberto nos parágrafos precedentes, quando abordamos a questão da concorrência, havia que voltar às coisas elas mesmas, havia que observar os fatos econômicos colocando-os sob 
parênteses, havia, finalmente, que buscar a essência do sistema capitalista. Havia que atingir o "eidos" do sistema de produção capitalista liberal. A concorrência era, segundo Euken, a essência do neoliberalismo nascente. A outra conseqüência, essa mais prática e importante para meus objetivos, é de que Euken, e conseqüentemente seus discípulos (Von Mies e Hayek) travaram em Friburg, conhecimento com vários juristas que foram muito importantes na construção do edifício jurídico alemão do século XX. Esses juristas, também eles influenciados pela fenomenologia de Husserl, trabalhavam para reelaborar uma teoria do direito que escapasse às injunções do historicismo do século XIX. Tudo isso nos conta Michel Foucault no curso denominado "O nascimento da biopolítica”.

Agora temos elementos para abordar práticas de governabilidade propostas pelo neoliberalismo. Na realidade apenas uma dessas práticas, e, depois, rejuntar todas as histórias, tentando entender como tudo isso pode ter a ver com a história do registro de novos medicamentos, e como, por sua vez esse ato jurídico, se relaciona com a história da ciência médica contemporânea, com suas práticas cotidianas, com sua valência humana.

Lembremos em que marco histórico estamos ancorados. Estamos no pósguerra, na Alemanha, e, estamos buscando uma forma de entender como nasceu naquele país uma nova forma de governabilidade. Como se construiu um novo Estado, uma vez que a legitimidade do antigo havia sido negada pela própria história. A partir desse ponto, discute-se, sob os princípios do neoliberalismo que estava nascendo, quais seriam as regras e a maneira correta de renovar o capitalismo. Essa renovação passava pela introdução dos princípios gerais do Estado de Direito no interior da legislação econômica, e essa relação era diferente dos princípios propostos pelo liberalismo clássico.

Há aqui um outro detalhe da história que deve ser considerado brevemente. $\mathrm{Na}$ perspectiva neoliberal, a instituição de um Estado de Direito na ordem econômica não significava mais uma espécie de alternativa positiva ao despotismo e ao estado policialesco que se construiria nos séculos precedentes. Avançar na descrição desse detalhe histórico nos ajudaria pouco 
em relação aos objetivos finais do trabalho. Um salto direto para a concepção neoliberal de estado de direito nos colocará diretamente em frente a nossa matéria. Poderemos a partir dessa explicação, voltar à linha melódica inicial e recontar a história dos registros de novos medicamentos, só que agora, não mais na perspectiva de um romance liberal, mas enquadrado no contexto regulatório e econômico das sociedades ocidentais.

$\mathrm{Na}$ perspectiva neoliberal, não pode haver intervenções legais do Estado na ordem econômica a não ser através da introdução de princípios formais. Toda legislação econômica é, grosso modo, apenas um código de regras, um espaço real onde os agentes econômicos podem livremente exercer suas atividades.

Essa concepção se opõe fortemente à idéia de uma planificação econômica dirigida pelo Estado. Ainda hoje, no ocaso teórico e prático do neoliberalismo, ou de uma rediscussão de suas formas de atuar, frequentemente se busca nas estruturas formais de uma planificação central as alternativas políticas para as crises econômicas. Mas afinal o que é um plano econômico? E o que uma discussão sobre esse ponto poderia nos ajudar?

Um plano econômico é, em poucas palavras, a instituição de medidas pelo poder público, em substituição ao indivíduo, e que normalmente tem uma finalidade explícita. Esta pode ser o crescimento econômico, a diminuição de uma alta taxa de inflação interna, ou até a correção de uma eventual injustiça ou desigualdade social. Isso, em resumo, é um plano econômico. Nós brasileiros temos larga experiência com a implementação de planos econômicos. O que se sente na prática? O poder público constitui-se como sujeito econômico e arbitra sobre o conjunto de processos econômicos!

Pois é exatamente o oposto disso, o que dita as regras do neoliberalismo. Não se trata de planejar com um fim específico, não se trata do Estado assumir a posição central do sujeito universal do saber econômico. Trata-se, isso sim, de construir regras juridicamente perfeitas e que permitam que os indivíduos exerçam sua liberdade econômica dentro dessas regras. Inclusive, o próprio Estado, uma vez que ele é também um agente econômico. Importa é que haja 
regras que pareçam sejam claras, ou que pelo menos a maioria dos envolvidos concordem que são claras.

Portanto, para os neoliberais, a relação entre instância jurídica e ordem econômica deve ser entendida como um quadro, onde a economia é uma espécie de jogo, e a instituição jurídica como o conjunto de regras formais desse jogo. Um aspecto importante essas regras é que elas são previamente conhecidas e sempre consensuadas entre a maioria dos jogadores.

Michel Foucault resume toda essa história da seguinte forma: "O Rules of Law e o Estado de Direito formalizam a ação do governo como um prestador de regras para um jogo econômico em que os únicos parceiros e os únicos agentes reais devem ser os indivíduos, ou digamos, se preferirem, as empresas", ou em uma outra frase, essa mais teatral, ao se referir a um economista clássico de formação liberal, o austríaco Joseph Schumpeter: "Na verdade uma economia planificada, não pode deixar de ser politicamente custosa, isto é, de ser feita à custa da liberdade". 


\section{Relação entre o neoliberalismo, o pragmatismo norte-americano, e o registro de novas drogas nos Estados Unidos.}

Pode parecer estranho tentar estabelecer uma relação entre uma teoria econômica que se formou em pleno berço do Estado hitlerista e os Estados Unidos, país onde o liberalismo assumiu proporções inimagináveis, mesmo para os defensores clássicos dessa corrente de pensamento. De fato, se a história da humanidade se resumisse ao senso comum, ou, às narrativas cinematográficas de Hollywood, essa tese não resistiria a um piscar de olhos. Entretanto nossa aposta é de outra natureza. Vamos seguir adiante tentando achar pontos de articulação entre discursos que esclareçam melhor os fatos. A idéia de que o arcabouço jurídico do registro de novos medicamentos, e a influência deste na prática médica contemporânea, representa um desenvolvimento inevitável da racionalidade científica, tanto do direito quanto da medicina, é, na minha visão, uma explicação incompleta de como as coisas aconteceram. Há, portanto, que tentar avançar um pouco mais.

Novamente temos que tentar nos situar historicamente. Para estabelecer essa relação temos que sair do pós-guerra imediato. Já descrevemos como os modelos de planificação central foram instituídos em quase todos os países do mundo, sob a égide, nem sempre absolutamente verdadeira no plano teórico, da teoria econômica de Keynes. Já descrevemos grosseiramente os fundamentos teóricos e o lastro prático operacional dessas políticas. Apontamos também para o esgotamento de todo esse sistema que culminou com a grave crise econômica dos anos setenta. Pois bem, é exatamente nesse ponto que quero retomar a análise. Após algumas digressões filosóficas e históricas, várias idas e vindas no tempo, e incursões em terrenos aparentemente sem nenhuma relação com o objeto desse estudo, finalmente, estamos nos aproximando do período que de fato importa estudar para entender como a metodologia científica, hoje hegemônica na medicina, 
realmente nasceu, e, principalmente, como se cristalizou na forma de um gabarito de inteligibilidade dos problemas práticos da clínica.

Penso haver três formas de estabelecer essa relação. Refiro-me, para retomar o fio do discurso, à relação entre o neoliberalismo alemão, cujas origens intelectuais, como vimos, nos remete à fenomenologia husserliana, e um país, como os Estados Unidos da América, cuja principal característica histórica é exatamente a permanente afirmação de uma ideologia do tipo liberal. Porque e como, uma nação embebida em uma arte de governar historicamente liberal teve que, em um determinado momento, repensar seus modelos e práticas. Quais os determinantes desse momento histórico? Penso haver três formas de estabelecer essas relações: 1) as relações entre as biografias dos principais personagens do processo histórico, 2) a descrição da crise econômica das décadas de sessenta e setenta, e, por último, 3) a explicação do conceito de utilitarismo e pragmatismo na filosofia anglo-saxã. Essas três formas se entrecruzam, formam uma explicação única. Sua divisão nesse contexto é meramente uma questão de estilo, e, também, uma preocupação de tentar não deixar nenhum flanco histórico desguarnecido.

\section{Relações entre as biografias dos principais personagens históricos}

A primeira forma, a de relações biográficas, é a mais simples, mas talvez a de maior poder de convencimento, por suas características um pouco novelescas. Vamos a ela.

Frederick Hayek, um dos participantes do encontro na Suíça a que nos referimos atrás, tão logo teve que fugir dos nazistas, refugiou-se na Inglaterra e desde então manteve um intenso relacionamento com economistas norteamericanos. Dentre os vários relacionamentos que ele estabeleceu nos EUA, destaca-se o vínculo que manteve com Milton Friedman, que, como vimos, era figura central da Escola de Economia da Universidade de Chicago. Essa Escola teve papel de destaque na agenda de recuperação da economia americana pós-crise dos anos setenta. 
Hayek é um pensador muito interessante e original. Infelizmente sua argumentação, na maior parte das vezes de cunho econômico formal, dificulta uma aproximação por não especialistas. Contudo, penso que às vezes vale o esforço de penetrar no mundo das "curvas de demanda" e das "situações de equilíbrio walrasiano" para tentar entender sua concepção de mundo e de ciência. Em meio a essa literatura técnica há um livro que desponta por sua simplicidade e pela incalculável influência que exerceu sobre os principais líderes das nações desenvolvidas ocidentais a partir de 1970.

O livro chama-se "O Caminho da Servidão", no original em inglês: "The road to Serfdom" (Hayek, 2007). Esta obra foi originalmente publicada em 1944 na Inglaterra e teve sua primeira edição impressa nos Estados Unidos exatamente pela editora da Universidade de Chicago. A tese central do autor é de que todas as formas de coletivismo levam a um único e inevitável destino: a tirania.

Ele usa sistematicamente exemplos da Alemanha nazista e da União Soviética para dar suporte prático a sua argumentação. Segundo Hayek, em qualquer sistema econômico que seja baseado em uma planificação central, a distribuição e alocação de recursos e bens iriam certamente se concentrar nas mãos de um pequeno grupo de pessoas, e, estas, jamais seriam capazes de processar todas essas informações de forma a atender aos interesses de toda a sociedade. Nessas condições a distribuição dos recursos e das informações sempre se processa de forma inadequada. A conseqüência prática dessa dissociação entre intenção, fluxo de informação e, distribuição de riqueza, seria inevitavelmente a necessidade de uma série de ações de natureza coercitiva por parte do Estado para fazer com que seus planos iniciais fossem de fato executados.

Ainda segundo o economista, a falta de decisões consensuais numa sociedade gerida através de planificação central, a respeito da melhor forma de se implementar um plano econômico, associado à falta de recursos do Estado planificador de efetivamente colocar em prática esse seu plano, que, eventualmente, até pode ser considerado bom pela maior parte da sociedade, 
cria um perigosa situação em que as pessoas, na busca de ver o plano realizado e funcionando, buscam dar ainda mais poder ao Estado, na maior parte das vezes outorgando a um "Homem Forte" o dever de conseguir realizar a tarefa que supostamente tem que ser feita para resolver os problemas. A conseqüência disso tudo é, segundo Hayek, inevitavelmente o totalitarismo. Em contraposição direta a essa forma de governar, Hayek sugere fortemente que a garantia institucional da livre concorrência deve de fato ser o único objetivo de um governo que garanta, para todos os indivíduos que o legitimam, uma verdadeira liberdade pessoal e econômica.

Essa obra e esse autor foram citados, para se estabelecer uma ponte, digamos, de natureza biográfica, entre as necessidades históricas do pensamento econômico da Europa continental de se auto-renovar, e as práticas governamentais instituídas a partir da década de sessenta nos EUA e no resto do mundo, para tentar "salvar" o sistema liberal capitalista de suas próprias contradições e das conseqüências de suas decisões tomadas após o término da Segunda Guerra Mundial. Para que essa relação fique completa falta citar o outro lado, falta dizer quem utilizou as regras desse pensamento para construir uma nova forma de governar.

Ronald Reagan e Margaret Thatcher, cada um de um lado do Atlântico, viam na obra de Hayek um dos pilares das reformas institucionais que ambos promoveram em seus respectivos países. Não deve ser pura coincidência o fato do nome de algumas obras escritas da Primeira Ministra inglesa remeter de alguma forma à obra citada de Hayek: "The Path to Power", "In Defence of Freedon". A base dessas reformas, como já vimos anteriormente, e analisaremos em maior profundidade especificamente para o segmento farmacêutico, posteriormente, era a construção de regras legais com intervenção mínima do Estado, e onde uma suposta livre concorrência entre os agentes garantiria de per si o crescimento e o desenvolvimento econômicos. Nos próximos parágrafos vamos entender melhor como se processou na prática essa relação biográfica entre Hayek (neoliberalismo alemão), Milton Friedman (Escola de Chicago) e Ronald Reagan/Margareth Thatcher. 


\section{A crise econômica das décadas de sessenta e setenta - A primeira crise.}

A segunda forma de se estabelecer uma relação entre o neoliberalismo alemão e o sistema de governabilidade americano, é, simplesmente, contextualizar a implementação de uma nova forma de governar com a crise econômica que aconteceu nos EUA logo após o esgotamento do modelo implementado com o "New Deal".

O extraordinário sucesso político da "Teoria Geral" (Keynes, 1982), publicado por Lord Keynes em 1936, instituiu um rico debate entre duas tradicionais universidades inglesas. De um lado Keynes, na Universidade de Oxford, defendendo a implementação de uma política econômica através do gerenciamento ativo da demanda, com o objetivo de, se não acabar, pelo menos reduzir drasticamente as crises próprias dos sistemas econômicos. Do outro lado o Prof. Hayek, na London School of Economics, defendendo a tese de que as crises eram parte integrante do processo, portanto inevitáveis, e que somente os indivíduos agindo livremente e por conta própria, em busca de seus próprios interesses individuais, poderiam de fato gerar as informações necessárias para promover uma coordenação inteligente do comportamento social que efetivamente conduzisse ao crescimento de uma nação. Novamente vemos a noção de liberdade conduzindo todo o processo. A liberdade de ação individual e a liberdade de preços estão na base do pensamento desse famoso economista. Voltaremos a esse ponto, tentando esclarecê-lo de uma vez por todas, ou pelo menos esclarecer o que pensamos dele, no próximo tópico.

Colocando as coisas numa perspectiva bem simples, pode-se dizer que os argumentos keynesianos a favor da intervenção do Estado como de uma ação governamental coerente e racional, dominou o proscênio dessa discussão até praticamente o início da referida crise que vamos descrever. E o que foi essa crise? Já vimos em parágrafos anteriores seus determinantes, vamos agora descrever algumas de suas características.

Do ponto de vista macroeconômico, observou-se nos EUA, um aumento importante da inflação e do desemprego. Ambos atingindo cifras em torno de 
dez por cento, o que é extremamente alto para os padrões norte-americanos. Junto com esses fatos, deve-se notar que os objetivos previamente estabelecidos nas décadas anteriores de repactuação do compromisso social entre capital e trabalho, fizeram com que de fato houvesse uma redução da concentração da riqueza no conjunto da sociedade. Nos Estados Unidos, por exemplo, a parcela de renda nacional nas mãos do $1 \%$ mais ricos caiu de uma taxa de 16\% antes da Segunda Guerra, para menos de $8 \%$ depois desse período, tendo ficado próximo desse patamar por alguns anos. Enquanto 0 crescimento se mantinha em níveis altos, essa questão não se constituía propriamente num problema político importante, uma vez que, ter uma parcela estável de um bolo que cresce, não chega a afetar seriamente interesses consolidados. Entretanto, com a inflação da década de 70 , os valores dos ativos presentes nas mãos dessa parcela mais rica da população tiveram uma queda considerável. Isso, sim, gerou um problema político importante que teve que ser enfrentado (Harvey, 2008).

Do ponto de vista institucional, um bom exemplo que, de uma certa forma, descreve a melhor resposta da parcela mais rica da população que vinha perdendo sua riqueza, foi a reestruturação pelo Presidente Nixon de um órgão denominado "Office of Management and Budget (OMB)". Este escritório tinha como função principal preparar o orçamento nacional e supervisionar sua implementação pelas várias instâncias administrativas do governo. O OMB tinha também outras importantes funções, dentre as quais destaco a que nos interessa em particular, que é a coordenação das solicitações de natureza legislativa, provenientes das Agências Federais. Na época da reformulação da OMB, o Presidente Nixon, um republicano tradicional, chegou a declarar: "agora somos todos keynesianos". Estranha declaração, sobretudo se considerarmos que, exatamente naquele período, se estava justamente buscando uma alternativa, para os processos de planificação central da economia. Esta, como vimos, estava deixando de gerar resultados.

Na prática, a função de coordenação das solicitações legislativas significava exatamente a matéria do nosso principal interesse, qual seja: a construção de regras, consolidadas no formato de lei, e que serviriam de base, ou arcabouço 
jurídico institucional, que orientasse a ação das empresas. Em capítulos posteriores vamos descrever esse assunto em detalhes, abordando-o especificamente na construção do "edifício regulatório" construído em torno do registro de novos medicamentos.

Por enquanto, para antecipar parte da descrição que se seguirá, vale dizer que o OMB tem uma história muitíssimo interessante. Por ser diretamente ligado à Presidência da República, e, sobretudo por congregar interesses diretamente vinculados a orçamento e regulamentação, o OMB sofreu (e ainda sofre) as mais diversas influências, digamos, ideológicas, pela falta de uma palavra melhor. No que tange a questão do marco regulatório de novos medicamentos, vemos um movimento, sobretudo relacionado ao e, discutido no Congresso Americano, que aponta para uma solicitação de flexibilização das regras, de forma a torná-las menos custosas e mais rápidas de se implementar. De dentro da discussão, observa-se uma interessante tendência por parte dos produtores de medicamentos de solicitar, não exatamente uma ausência de regulação, mas que esta fosse secretariada pela própria indústria farmacêutica e que atendesse a seus interesses monopolísticos (Dukes, 2005). Essa tese será mais bem explorada posteriormente.

Ao analisar a documentação disponível sobre a OMB, observa-se que, desde sua aurora, o tom que comanda a ação desse escritório é a tentativa de assumir o controle da agenda de construção de uma nova racionalidade norteadora da regulamentação federal. Essa nova racionalidade, ainda sob forte influência do primado da planificação central, aponta para considerações indispensáveis de análise de relação custo $x$ efetividade para toda e qualquer nova tentativa de regulamentação. É na regulamentação ambiental onde se observa mais claramente essa complexa e nascente relação de interesses contraditórios e, às vezes, francamente opostos, entre o Estado, as empresas, o os direitos dos cidadãos. A questão da preservação do meio ambiente tinha na época o interessante nome de "preservação da qualidade de vida".

$\mathrm{Na}$ tentativa de se construir uma posição consensual nesse campo, que, se ainda hoje é considerado polêmico, no início dos anos setenta, em plena crise 
econômica, assumia proporções de verdadeira novidade, o Governo do Presidente Nixon, instituiu um conselho denominado "National Industrial Pollution Control Council (NIPCC)". Um relatório desse comitê datado de 1971 diz: "A crescente preocupação pública com as conseqüências da poluição em nossa opulenta sociedade, inspirou respostas de natureza regulatória que são incompatíveis com a saúde econômica de nossa sociedade. Padrões foram estabelecidos que são inatingíveis do ponto de vista de custos economicamente toleráveis...recomenda-se que novos estudos sejam elaborados para se concretizar essa visão em termos de relação de relação custo x benefício mais rigorosa" (The American Presidency Project. Presidential executive orders. Special Message to the Congress on Environmental Quality)

O método de remontar à origem da inflexão dos critérios de regulamentação da década de setenta tem o objetivo de mostrar que, desde essa época, que coincide com a crise do sistema econômico de planificação, o movimento político e administrativo americano foi todo no sentido de criar regras que apontassem para uma racionalidade da intervenção do Estado baseado no custo que esta imporia à sociedade como um todo.

Alguns anos depois ocorreu a verdadeira inflexão teórica nesse assunto. Esta ocorreu no governo do Presidente Reagan. Vamos ver rapidamente como isso aconteceu. Como vimos, o Presidente Reagan foi um dos mais importantes articuladores políticos de uma reforma pragmática do liberalismo. O único personagem que se aproxima dele em importância foi a Primeira Ministra Britânica Margareth Thatcher. Com o objetivo de amarrar as histórias, é bom relembrar que ambos tinham na obra fundamental de Hayek "The Road to Serfdom" a principal referência e justificativa científica e acadêmica de suas ações políticas.

E o que foi exatamente essa inflexão? Aqui os textos são claros e explícitos no sentido de dizer que todas as regras regulatórias deveriam ser revisadas com 0 objetivo específico de impedir: "efeitos adversos negativos sobre a competição, o emprego, investimentos, produtividade, inovação ou na habilidade dos empreendedores situados nos Estados Unidos da América de competir com 
empreendedores de países estrangeiros, tanto no mercado interno quanto no mercado externo". Esse texto é uma tradução literal "Executive Order (EO)" assinada pelo Presidente Reagan em 1981 e que é uma diretriz geral de como as agências regulatórias deveriam agir a partir daquele momento (The Federal Register. Presidential executive orders. Executive order 12291).

Vale a pena passar rapidamente por outros trechos desse mesmo documento para melhor nos situarmos em nosso objeto. Na seção dois, denominada "Exigências Gerais", está escrito: "As agências devem direcionar suas prioridades regulatórias com o objetivo de maximizar o benefício líquido agregado para a sociedade, levando em consideração as condições das indústrias em particular afetadas pela regulação, as condições da economia nacional, e outras ações regulatórias contempladas para o futuro".

Chama a atenção, não somente nessa "Executive Order", mas também em outros documentos da época promulgados pelo Governo Reagan, a extrema importância, quase uma obsessão, que havia na época, de ter como princípio normativo de racionalidade legislativa a relação entre custo e benefício de qualquer regulamentação proposta. Essa tendência já estava presente no Governo Nixon, mas tornou-se uma essência, a partir do Governo do Presidente Reagan. A linguagem tem caracteres contábeis. Por exemplo: "Ações regulatórias não devem ser realizadas a não ser que os benefícios potenciais para a sociedade suplantem os mesmos custos para a esta sociedade". "Os objetivos regulatórios devem ser escolhidos de forma a maximizar os benefícios líquidos para a sociedade" (The Federal Register. Presidential executive orders. Executive order 12291).

Era de se esperar que uma Ordem Presidencial como essa, gerasse por parte das Agências Regulatórias uma reação no sentido de questionar os limites aceitáveis para interferência do Poder Executivo em decisões legislativas, que, promulgadas por agentes do Poder Executivo, passavam (e ainda passam) por intensa discussão e controle por parte dos outros poderes e da própria sociedade. 
O aprofundamento dessa questão, nesse momento, seria contraproducente no sentido de atingirmos nossos objetivos. Certamente abordaremos esse discurso especificamente no caso da regulamentação de novas drogas posteriormente, quando tratarmos da crise institucional que se constituiu em torno dos métodos e procedimentos do FDA, mas penso que vale citar um texto extremamente elucidativo e que tem o interessante nome de "The Quiet Shift of Power" (Center for Regulatory Effectiveness). Novamente o assunto em voga é a legislação ambiental e ele foi publicado em 1984. Alguns pontos chamam a atenção nesse assunto dos limites da ação presidencial sobre a regulação das agências americanas. Em primeiro lugar, vale ressaltar o primado absoluto da ordem legislativa. Toda discussão circula em torno da legitimidade institucional e constitucional dos atos do Presidente da República, e do seu braço executivo no que tange a questão da ordem regulatória, o já mencionado OMB. Em segundo lugar vale registrar que esse texto discute com alguma profundidade a questão de se considerações de natureza não estatutária, particularmente a já referida questão da relação entre custos e benefícios, poderiam ser enxertadas (é exatamente essa a palavra empregada, em inglês: "engrafted") dentro do processo de decisão das agências.

Já foi falado o suficiente sobre a forma de agir do Presidente Reagan. Muito mais poderia ser escrito sobre as ações de ordem prática desse famoso presidente americano no que tange a reformulação da ordem de produção econômica mundial e suas relações com aspectos legislativos, particularmente nas questões de natureza regulatória. Outro personagem responsável por uma nova guinada nas questões de regulamentação, esta ainda mais importante para nosso estudo, surgiu cerca de dez anos depois. Refiro-me ao Presidente, este do partido democrata, William J. Clinton.

Sua "Executive Order" publicada em 30 de Setembro de 1993 é muito mais complexa do que as discutidas anteriormente, o que torna sua interpretação, sobretudo por um não especialista, uma tarefa proporcionalmente mais difícil e arriscada. 
Logo a primeira frase chama a atenção por sua retórica direta (aliás chama a atenção a objetividade pragmática do discurso jurídico legislativo norteamericano em contraste, às vezes marcante, com os hábitos tortuosos e rebuscados freqüentemente empregado em nossa língua). A referida "Executive Order (E.O.)" do Presidente Clinton tem o número 12866 e se intitula: "Regulatory Planning and Review". Aquela do Presidente Regan chamava-se simplesmente: "Federal Regulation". Ela começa da seguinte forma: "The American people deserve a regulatory system that works for them, not aganist them: a regulatory system that protects and improves their health, safety, environment, and well being, and improves the economy without imposing unacceptable and unreasonable costs on society regulatory policies, that recognize that the private sector and private markets are the best engines for economic growth, regulatory approaches that respects the role of the State, local and tribal governments, and regulations that are effective, consistent, sensible, and understandable. We do not have such a regulatory system today" (The White House. Presitential executive orders Executive order 12866 Regulatory Planning and Review).

Ao longo do texto, vários aspectos significantes apontam para a maior complexidade da ancoragem legal das regras propostas. A Seção 1 intitula-se "Statment of Regulatory Philosophy and Principles". Nenhuma outra Ordem Presidencial sobre regulação anterior havia construído um marco teórico tão bem definido. Este marco reserva para a sociedade, em sua interlocução com as instâncias públicas, a prerrogativa, totalmente ausente nas Ordens anteriores, de simplesmente não regular, caso a relação entre custo e benefício seja de alguma forma desfavorável para a sociedade. Claro que a discussão sobre os parâmetros aceitáveis dessa relação não se encontram presentes numa discussão a esse nível, mas, quando formos abordar a questão específica da regulamentação de registro para produção, comercialização e marketing de novos medicamentos, esse ponto será consideravelmente aprofundado.

Vários outros aspectos relacionados à essa Ordem Presidencial chamam a atenção. Observa-se nela uma preocupação muito grande de garantir para as 
agências reguladoras a responsabilidade legal pela decisão de se deve ou não regular um determinado segmento econômico, cabendo à $\mathrm{OMB}$ a função de controlar todo o processo e aconselhar o Presidente da República. O eixo do poder de decisão, a essa altura histórica, havia novamente se deslocado. Digamos que a ideologia do processo de análise de custo efetividade nas decisões regulatórias, que nascera na década de setenta com Nixon e que se revelara abertamente na década de oitenta com Reagan, havia já permeado e se constituído em verdadeiro consenso na sociedade americana no início da década de noventa. Isso não estava mais em discussão, não era propriamente um objeto de polêmica. A questão agora era garantir institucionalmente a aplicação dessa regra normativa. Garantir o cumprimento da prescrição!

Como disse, esse assunto será abordado em maiores detalhes ao longo de desenvolvimento desse trabalho, particularmente quando tratarmos das discussões sobre custo efetividade e defesa da proteção patentária na área de medicamentos, mas, por enquanto, a título de antecipação e para situar melhor essa discussão no nosso objeto, penso que vale a pena tentar um resumo do percurso trilhado pela sociedade americana para a definição das regras regulatórias na área de medicamentos.

Esse resumo tem três módulos: 1) A busca de um consenso negociado na sociedade, representada por seus vários agentes (população, indústria farmacêutica, agências reguladoras, poder executivo, instâncias legislativas, etc...). 2) A busca de um denominador comum de linguagem que fosse aceita e entendida por todas as partes que estivessem envolvidas no assunto. Essa linguagem, na maior parte dos campos, mas particularmente na área de medicamentos, se chamava linguagem científica. Na realidade essa forma de argumentação desde sempre esteve presente como forma de julgar interesses contraditórios, mas, a partir dessa época, ela passou a ser praticamente hegemônica. A razão passa a ser aquilo que a ciência nomeia. 3) $O$ deslocamento funcional da agenda da construção das regras normativas, que migrou das mãos do Estado, para as mãos do empreendedor privado. Esse último passou a ser o mais habilitado agente para conduzir a discussão para o plano prático. O amálgama desse deslocamento é, do ponto de vista prático e 
teórico, como vimos, que a competição entre os vários agentes é a essência (o eidos) do processo produtivo. Se assim é, ninguém vai agir contra a lei essencial e natural da competição, pois se uma ação, de alguma forma não for do melhor interesse de toda a sociedade, esta mesma sociedade através da competição, expurgará o erro de suas entranhas. Em poucas palavras: é a construção da base de um sistema que permite a auto-regulação.

Antes de avançarmos para a terceira tópica que justifica a ligação histórica entre o neoliberalismo alemão do início do século e o edifício regulatório para novos medicamentos de hoje em dia, há que se destacar um outro e importante aspecto da E.O. 12866. Refiro-me à importância que a questão da resolução de conflitos (ou a previsão de sua ocorrência), ganha nesse contexto. Essa questão se desvela sobre duas perspectivas, que, na realidade, são complementares. Por um lado a representação lingüística, quase obsessiva de amparar todas as deliberações, ou mesmo definições, no arcabouço legal do Estado Americano. A expressão "de acordo com o permitido pela lei" aparece inúmeras vezes no texto. Por outro lado, no 'tem 7 da E.O., intitulado "Resolution of Conflicts" define-se como responsável final por qualquer contencioso a respeito de questões regulatórias, sobretudo quando não há consenso entre a Agencia Reguladora e o OMB. Nesses casos, define-se como o juiz final sobre opiniões divergentes na matéria, o próprio Presidente da República: "To the extent permitted by law disagreements or conflicts between or among agency heads or between $\mathrm{OMB}$ and any agency that can not be resolved by the administrator of OIRA shall be resolved by the President, or by the Vice President acting at the request of the President, with the relevant agency head".

\section{Relação histórica entre o Utilitarismo e de Pragmatismo}

Por último, para encerrar os pontos de articulação entre o neoliberalismo alemão do início do século, o sistema de regulação americano que se constituiu a partir dos anos sessenta e, finalmente, a arte de governar e de produzir verdade em medicina nos dias de hoje, vamos ter que novamente 
mergulhar no pouco palpável mundo das idéias. Após descrições de teses de economistas e textos políticos e administrativos, vamos ter que voltar aos livros de filosofia, tentar estabelecer relações entre tempos difíceis de mensurar, regiões geográficas cujas fronteiras estão longe de serem bem demarcadas, e, sobretudo, onde a concepção de um único autor se dilui nas múltiplas interferências e influências comuns e coincidências de posturas reflexivas que podem existir, quando se consideram todas as possibilidades de referências disponíveis. Ao contrário dos dois outros tópicos que precederam este, nos quais as referências eram facilmente identificáveis e suas relações recíprocas relativamente fáceis de se perceber, aqui corremos o enorme risco de tomar por reta uma linha que é curva ou vice-versa. Autores índices serão utilizados, mas, é bom que se diga antecipadamente, essas escolhas terão mais um caráter de necessidade de formalização didática do que eles de fato representem uma linha de continuidade histórica necessária.

Vou tomar como ponto de partida o filósofo inglês do século XVIII, David Hume. $\mathrm{Na}$ verdade Hume era escocês e talvez o mais destacado pensador do que foi considerada a Grécia da modernidade, os pensadores escoceses do século XVIII. Infelizmente a leitura dessa tradição filosófica é relativamente incomum nos países latinos. A riqueza de suas reflexões sobre as ciências da natureza, moral e ciências humanas, incluindo história, além de sua influência direta sob o olhar moderno desses mesmos assuntos é enorme, como tentarei mostrar abaixo (Hume, 2004).

Os principais rótulos que a tradição filosófica coloca em Hume são de que ele é um autor de tradição ceticista, e, ao mesmo tempo, um empirista. Ao contrário de tentar descrever o que esses rótulos significam, vou preferir seguir o caminho mais perigoso de penetrar no pensamento humiano e ver o quanto esses rótulos podem nos ser úteis na defesa de nossa argumentação principal.

Além dos rótulos, quando se trata de delimitar a contribuição fundamental de Hume, pensa-se em dois aspectos: 1) a Teoria das Associações das Idéias, onde ele nos mostra como uma idéia ou sensação evoca outra idéia ou sensação, 2) a sua célebre análise do Princípio de Causalidade. Vamos 
descrever em um pouco mais detalhes o que essas contribuições significam, mas antes é importante destacar que o conjunto da obra de Hume aponta mais para a construção de uma noção prática de governar e produzir conhecimento em uma sociedade do que propriamente para se discutir epistemologia, ou construir regras para justificar e entender a volumosa e relativamente nova produção científica sobre a natureza da sua época. A título de curiosidade é importante lembrar que Hume é de uma geração que se seguiu imediatamente após ao gênio inglês das ciências da natureza, Isaac Newton. Quando este morreu, em 1727, Hume tinha dezesseis anos (Monteiro, 2009).

Para Hume, e por isso ele é reconhecido como um empirista, todo conhecimento deve prover da experiência sensorial. O que para nós, modernos, mergulhados até a cabeça no paradigma da verdade científica, pode parecer uma obviedade, para a época de Hume isso definitivamente não era assim tão óbvio. O critério de definição de verdade era muito mais relacionado às idéias do que propriamente aos fatos. Estes últimos deveriam apenas corroborar os primeiros. Nesse quadro geral se encaixam a Teoria da Associação das Idéias e o Princípio de Causalidade.

Para Hume, uma idéia evoca uma outra idéia, que por sua vez evoca uma terceira, e, assim por diante. As correlações são estabelecidas por proximidade, semelhança, relação temporal, etc.Essas idéias evocadas são sempre de natureza subjetiva e variável, não sendo, portanto, sistematizáveis. Entretanto, e aqui começa a grande ruptura do pensamento de Hume em relação à tradição metafísica que o precedeu, há na observação ou descrição entre os fatos observados, uma constante. Essa constante se constitui em nada mais nada menos que a estrutura fundamental do que ele chamou de Natureza Humana (Hume, 1972).

Para simplificar um pouco essa história, o que caracteriza a natureza humana no que tange à observação e descrição do mundo, não são as idéias que temos do mundo, tão pouco são os fatos que observamos, mas o que, de fato, define essa natureza, são as relações ou regras que estabelecemos para os fatos que observamos. Se nos ativermos na profundidade desse pensamento, 
é provável que cheguemos à conclusão de que essa Teoria das Associações das Idéias esteja no fundamento mesmo da lógica do raciocínio moderno, em particular do método científico $e$, conseqüentemente da medicina contemporânea.

Para Hume as relações são exteriores aos termos, o que quer dizer que as primeiras não estão contidas nos termos nem nas idéias que eles evocam por continuidade. O fundamento mesmo do conhecimento está no formato da relação identificada.

Essa teoria do conhecimento traz uma conseqüência para a vida real que é extremamente relevante para defesa de nossos objetivos, e à qual, apesar de impor um pouco mais de aprofundamento no mundo das idéias, não podemos nos furtar. Uma outra distinção do pensamento humiano em relação à tradição epistemológica da metafísica tradicional, é que, para o filósofo escocês, ao dissociar o conhecimento das idéias, e, simultaneamente, associá-lo à relação entre os fatos observados, essa operação faz do conhecimento uma atividade eminentemente prática. Uma coisa é assumir que, pelo fato do sol nascer todas manhãs, necessariamente é verdade que ele sempre teve esse comportamento, e que sempre o terá. Outra coisa, distinta, é, ao observar o nascimento do sol todas as manhãs, decidir estabelecer regras que, em seu conjunto, e pela relação dos fatos observados, pressupõem que, no dia seguinte ou num tempo a ser determinado, o sol deverá novamente nascer. A descrição da verdade se desloca do fato, ou da idéia que se tem sobre ele, para as relações que a mente constrói pelas impressões que esses mesmos fatos provocam (Hume, 1972; 2000).

É a quinta-essência do empirismo. Quando se trata das ciências da natureza, tudo isso faz imediatamente um grande sentido para nós modernos. Muitos diriam, esquecendo toda tradição aristotélica, que sempre foi assim, e que isso é óbvio. Outros, mais críticos, diriam que essa forma de colocar as coisas, representa apenas a evolução da razão científica, que nesse momento crucial da história da humanidade, o momento do nascimento da física moderna, nos libertamos do mito e ganhamos o passaporte definitivo para a compreensão do 
mundo fenomênico, da natureza. Não nos apressemos. Lembremos que Hume tem também o rótulo de cético, e necessariamente teremos que voltar a isso mais tarde, quando tentarmos dar um grande salto no tempo em direção ao século XX, em particular ao pragmatismo norte americano.

Portanto, para Hume, o conhecimento é uma atividade prática que é decorrente de uma característica intrínseca à natureza humana, e que se formaliza pelo estabelecimento de relações entre as impressões provocadas em nossas mentes pelos fatos que observamos. Isso também desloca a noção de causalidade, tão importante para a ciência contemporânea, do plano dos fatos para o plano das relações entre os fatos observados. Isso faz todo o processo ficar um pouco mais complicado.

Ainda há no empirismo histórico anglo-saxão uma outra característica não menos importante (na verdade ainda mais importante para nosso objetivo) que é a direção na qual as associações de idéias se processam. Uma direção necessária e que é imposta pela própria natureza humana. Há, segundo Hume, uma lei que direciona o fluxo dessas associações. Essa lei assume, na tradição empirista, mais de um nome. Vou, por questões retóricas, para ajudar na compreensão da lógica interna do meu discurso, chamar essa lei de: utilitarismo! E o que é o utilitarismo? Como isso se relaciona com a teoria do conhecimento na tradição da ciência, das leis e da política?

Há mais de uma definição para o utilitarismo. Há toda uma história do utilitarismo. Há toda uma linhagem de pensadores ancorados nessa tradição. Desde seu fundador Jeremy Bentham até o pensador norte-americano contemporâneo Richard Rorty, passando pelos economistas alemães que citamos anteriormente, contam-se dezenas de filósofos de orientação utilitarista. Apesar de ser extremamente importante para a argumentação desse trabalho entender exatamente o que define na prática o pensamento utilitarista, não faz parte desse projeto entrar nos detalhes das polêmicas internas desse pensamento. Felizmente, o que une a maior parte dos pensadores utilitaristas é uma coisa muito simples de explicar, uma coisa que faz parte da vida de todos nós seres humanos, de uma forma tão forte e evidente que espanta ter sido 
necessário constituir uma teoria ética para explicá-la. O princípio fundamental do utilitarismo é o de que o ser humano, em sua conduta habitual, sempre busca seu próprio prazer e foge de tudo que possa lhe causar dor. Esse princípio sofreu, desde sua primeira formulação moderna, com Bentham, até os dias de hoje, várias inflexões, redirecionamentos, aprimoramentos e mudanças. Duas dessas mudanças nos interessam e serão abordadas no momento apropriado: a redefinição do Século XIX do filósofo inglês John Stuart Mill, e uma espécie de genial simplificação efetuada no Século XX pelo pensador americano William James.

Por enquanto, vamos voltar a Hume e sua Teoria do Conhecimento, fundada em uma noção de natureza humana, a qual, como defendemos, guarda estreita relação com a ciência contemporânea conforme orientada pelo pragmatismo norte-americano. Aos poucos vamos nos reaproximando do nosso tema principal.

Para explicitar como o utilitarismo se encaixa na epistemologia humiana, teremos que avançar no terreno das ciências humanas. A essa altura, após incursões na história, na sociologia, na economia, e no direito, essa ousadia e arrogância, não é mais novidade. Vamos, a partir desse momento, e por força da necessidade de defesa de um argumento, ingressar no terreno da ética e da moral.

Dizer que o conhecimento se funda na relação entre suas partes constituintes, e que esta segue a direção do princípio de utilidade, implica dizer que o homem, por sua própria constituição como ser natural, por sua natureza humana, tende àquilo que the dá prazer e se afasta daquilo the prejudica. Portanto, ao definir o que é verdadeiro e o que é falso, necessariamente, as relações estabelecidas para construção desse veredicto tendem ao estabelecimento de conexões que maximizam o princípio natural de utilidade. Não é preciso muita reflexão sobre esse tema para concluir que, em uma sociedade composta por um grande número de pessoas, a aplicação prática do Princípio da Utilidade impõe imediatamente um problema de natureza moral. Antes, contudo, de abordarmos a essência do problema moral no pensamento 
de Hume, vale traçar um paralelo explicativo entre a Teoria da Associações de Idéias e o Princípio de Utilidade em áreas onde se constitui um saber qualquer, onde se produz um conhecimento.

Para Hume, no mundo social, somos impelidos pela nossa própria natureza a construir as relações entre os fatos sociais, de uma forma que nos aproximamos daquilo (idéias ou pessoas) que nos são próximas, que se nos assemelham e com as quais guardamos algum tipo de parentesco. $\mathrm{Na}$ interpretação dos fatos da natureza, por sua vez, construímos nosso código de verdade por aquilo que se assemelha, que tem alguma continuidade, por aquilo que estabelecemos relações causais (Hume, 2004).

Essa situação, voltando ao exemplo das ciências humanas, impõe uma solução moral. Essa solução ainda, que artificialmente criada, serve, segundo Hume, para que a própria natureza humana, em seus princípios ou leis, consiga, de uma forma pragmática, se manifestar em sua plenitude. A solução moral é o que Hume chama de "O artifício do Legislador". A tendência natural do ser humano é de construir regras de verdade por associação de idéias rumo ao semelhante, ao contínuo, ao que lhe é próximo. A relação causal impõe a construção de um mundo artificial que procure restringir os limites dessa tendência (Hume, 1972). É o artifício do legislador, é a super-estrutura jurídica. É o arcabouço regulatório! São regras que servem para garantir a manifestação espontânea da natureza humana quando simpatias ou utilidades contraditórias têm que conviver consensualmente. A questão prática que se coloca é como organizar um mundo objetivo que permita à natureza humana suplantar sua própria tendência natural à parcialidade.

Entender o Princípio da Utilidade e o problema moral que ele engendra constrói condições de entender o mundo artificialmente criado pela legislação. Hume é considerado por Gilles Deleuze, talvez em mais uma de suas torções do pensamento alheio, o verdadeiro pai da Economia Política (Deleuze, 2001).

Para Hume, a questão que se coloca não é mais, como para os iluministas da tradição filosófica continental, como Rousseau, corrigir naturezas 
eventualmente desviantes através da punição imposta pela força da lei, mas a construção de um mundo legal que consiga entender a natureza humana e sua tendência natural de simpatia pelo próximo, de uma forma que, através da construção de um sistema positivo que era denominado de "A Regra Geral", impor limites aceitáveis a essa tendência, de forma que, conflitos sejam evitáveis ou pelo menos bem resolvidos (Hume, 1972), (Hume, 2000).

Em resumo, o pensamento de Hume, tão importante para a história da ciência contemporânea, seja no seu aspecto natural ou social, repousa em três pilares fundamentais: 1) a Teoria das Associações das Idéias, 2) o Utilitarismo, 3) o arcabouço legal que controla, através da imposição de regras, a natureza do ser humano. Hume construiu a possibilidade do nascimento de uma ciência do homem. Através da descoberta de leis naturais. Através da identificação de invariáveis que regem a natureza humana. Defendo que, quando se fala em humanismo, há que se pensar, necessariamente, em David Hume.

Toda essa descrição um pouco extensa e enfadonha da epistemologia humiana tem três objetivos: o primeiro é traçar uma ponte entre o empirismo inglês do Século XVIII e o pragmatismo americano do Século XX, fechando, finalmente o terceiro ponto de ligação entre o neoliberalismo alemão do início do Século XIX e o pragmatismo americano do Século XX. Essa ponte foi arbitrariamente construída e sua demonstração demandaria uma tese em separado, importa nesse momento apenas registrar afinidades. O segundo é apontar para a relação histórica entre o empirismo em ciências e a instituição de uma ordem legal conforme conhecemos hoje em dia. O terceiro e último, dizer que o que normalmente chamamos de humanismo e suas várias derivadas lingüísticas como humanização, desumanização etc..., deve ser contextualizado nessa importante origem do conceito de "natureza humana".

Hume era um homem de muitos amigos. Conta a história que chegou a hospedar Rousseau em sua casa na Inglaterra, mas com quem acabou se desentendendo por questões desconhecidas (Monteiro, 2009). Talvez o "Bom Homem" roussoniano fosse incapaz de conviver com o pragmatismo social de Hume. Dentre os amigos do filósofo escocês, um merece destaque pelo objeto 
desse estudo: trata-se nada mais nada menos do que Adam Smith, filósofo moralista, considerado pela maioria como o fundador da Economia Política, e considerado por todos como o pai do liberalismo econômico. Uma das obras mais importantes de Adam Smith, denominada "Teoria dos Sentimentos Morais" (Smith, 2002), guarda relações bastante próximas com tudo o que foi dito sobre o pensamento de David Hume. Não há porque aprofundar a descrição dessa relação, certamente nos afastaríamos muito de nossos objetivos. Apenas gostaria de apontar para o fato de que essa epistemologia que dá sustentação ao liberalismo econômico clássico é a base em cima da qual se constitui o neoliberalismo.

A citação da obra de Adam Smith não é fortuita. Como veremos em maiores detalhes adiante, em meio a uma acalorada discussão, nos anos setenta, sobre qual deveria ser o papel do Poder Público na regulação de registros de novos medicamentos, um importante economista da Escola de Chicago, chamado Sam Peltzman, foi chamado a opinar. Nessa ocasião, foram discutidos no Congresso Americano os princípios e as conclusões dos seus trabalhos sobre os efeitos dos processos de regulamentação no desenvolvimento econômico de um país. Mais adiante vamos descrever com mais detalhes alguns desses embates no legislativo americano, eles foram extremamente importantes na decisão final do marco regulatório naquele país. Há uma síntese do pensamento desse economista que foi publicada com o interessante nome de "Regulation and the Wealth of Nations: The Connection between Government Regulation and Economic Progress" (Peltzman, 2007). Já no título observa-se uma relação com o pai do liberalismo pela referência ao termo "riqueza das nações", título da principal obra do pensador moralista escocês. Porém, logo na introdução, essa relação passa de implícita para explícita. Assim começa o texto: "A principal mensagem de Adam Smith é que, quando não regulado, retornos não distorcidos são maiores em uma atividade econômica do que quando regulados, o progresso econômico normalmente é promovido se os recursos fluírem em direção à atividade de maior retorno. Todos os recursos seguiriam esse fluxo se deixadas por sua própria conta e com o objetivo de perseguir nossa felicidade. Quando os reguladores fazem coisas que mudam 
esses sinais de mercado, ou nos impedem de responder a estes, a nação como um todo normalmente se torna mais pobre".

Sam Peltzman comenta especificamente sobre a regulação de novos medicamentos. Toda a argumentação do autor refere-se a que o custo imposto pela regulamentação em qualquer setor é sempre maior do se deixasse a livre concorrência do mercado se auto-regular. Outra importantíssima conclusão, que dá sustentação a nossa argumentação principal, é que a regulamentação tende a reduzir a capacidade de inovação. Voltaremos a esse texto e esse autor mais tarde. Por enquanto sua citação guarda três objetivos: 1) Identificar a Escola de Chicago como agente interlocutor das regras sobre registro de novas drogas, 2) apontar para a questão da relação custo efetividade como princípio normativo dessa regulação, e 3) associar a ideologia neoliberal com suas raízes históricas do liberalismo inglês e do utilitarismo, observadas na citação direta a Adam Smith e na referência ao Principio de Utilidade manifesto na expressão: "perseguir nossa felicidade".

Antes de darmos um salto rumo ao Século $X X$, ao pragmatismo americano e suas conseqüências, importa fazer uma breve parada em outro pensador inglês da tradição utilitarista que viveu no Século XIX. Refiro-me a John Stuart Mill. Esse filósofo tem um texto muito famoso que se intitula: "Sobre o Utilitarismo" (Mill, 2000). Não há espaço para uma discussão aprofundada desse interessante autor e suas idéias, mas um ponto da sua obra, em particular a que se refere ao seu conceito particular de utilitarismo, em contraponto ao que já descrevemos, merece um comentário em particular.

John Stuart Mill defende apaixonadamente a tese de que sempre que genuinamente se atinge a felicidade individual, esta necessariamente estará de acordo com o Princípio de Utilidade na perspectiva da coletividade à qual o indivíduo que a obteve pertence. Essa relação de necessidade é permeada, segundo J.S. Mill, por ações de natureza moral. O ato moral é um código de regras que implica necessariamente um cálculo, este é chamado por um dos principais fundadores do utilitarismo, e talvez o mais importante interlocutor de J.S. Mill, Jeremy Bentham, de "Cálculo de Utilidade". Esse cálculo é a 
prescrição de uma ação prática que visa otimizar o bem estar do conjunto dos seres sociais. Do ponto de vista econômico, o utilitarismo de Mill pode ser entendido como um princípio ético no qual o que determina se uma ação ou decisão é correta, é o benefício que essa ação exerce sobre a coletividade. Quanto maior o benefício tanto melhor deverá ser julgada a ação da decisão.

Em resumo pode-se dizer que a justificativa da ação moral, assim como a assertividade da ação política ou econômica, repousa no balanço positivo de seus resultados para o maior número de pessoas possível. O senso comum diria que o cálculo de utilidade é uma forma de justificar a máxima de que os fins justificam os meios. $O$ contra-ponto filosófico sobre o qual não me aventuro discorrer é o "Imperativo Categórico" que o filósofo alemão Immanuel Kant descreveu em sua Crítica à razão Prática tendo como um dos focos de análise crítica, justamente o pensamento moral de David Hume (Kant, 1986) .

Vejamos apenas dois pequenos trechos da obra "Utilitarismo", de J.S. Mill: "No entanto, essa base do poderoso sentimento natural existe, e é ela que constituirá a força da moralidade utilitarista, desde que se reconheça a felicidade geral como o critério ético. Essa fundação sólida é a dos sentimentos sociais da humanidade, o desejo de viver em unidade com nossos semelhantes, que já é um poderoso princípio na natureza humana, e felizmente um dos que tendem a se fortalecer mesmo sem ser expressamente inculcado pelas influências do progresso e da civilização. O Estado Social é, a um só tempo tão natural, tão necessário e tão habitual ao homem que, exceto em algumas circunstâncias incomuns, ou por algum esforço de abstração voluntária, jamais ele se concebe a si mesmo senão como membro de um corpo; e tal associação se fixa cada vez mais, conforme a humanidade se afasta do estado de independência selvagem. Ora, a sociedade entre os seres humanos, exceto a relação entre o senhor e o escravo, é manifestamente impossível numa outra base que não seja a da consulta ao interesse de todos". Outro trecho: "Todo fortalecimento dos laços sociais e todo crescimento saudável da sociedade não somente dão a cada indivíduo um intenso interesse pessoal em consultar na prática, o bem estar dos outros, como também o leva 
a identificar seu sentimento mais e mais com o bem deles ou pelo menos com um grau maior de consideração prática a respeito desse bem".

Definidas as bases do empirismo, bases essas que sustentam as ciências da natureza, e boa parte do que entendemos por ciências sociais, sobretudo aquelas relacionadas à tradição anglo-saxã, e, após uma pequena incursão sobre o conceito de utilitarismo, podemos agora dar o grande salto rumo ao pensamento que constitui o verdadeiro alicerce sobre o qual, segundo nossa visão particular, praticamente toda a ciência médica contemporânea, seja em seus aspectos de configuração social, ou em suas vertentes mais técnicas ou naturais, está assentada ou enraizada. Refiro-me aos princípios normativos do que a tradição da história da filosofia chama de pragmatismo norte-americano.

Quando analisamos o empirismo, dissemos que Hume tinha dois rótulos: empirista e cético. O primeiro foi analisado, pelo menos em seus conceitos fundamentais, o segundo, contudo, ainda não foi abordado. Há dois motivos para isso, o primeiro é a complexidade do tema. Definir ceticismo, mesmo dentro do empirismo inglês do século XVIII, mesmo dentro da obra de um único autor, mesmo dentro do pensamento do próprio Hume, é uma tarefa extremamente difícil. Há várias contradições entre os autores. Além disso, o sistema de referências que sustenta a posição de cada autor remete-nos freqüentemente a períodos longínquos no tempo, à Grécia pré-socrática, a Platão e Aristóteles, e isso como um fio solto, puxado de um tecido velho, nos faria fugir completamente do nosso objeto principal. Portanto, decidimos não avançar nessa discussão por questões práticas. Mas isso não significa que entender o fundamental sobre a noção de ceticismo em Hume não seja relevante para nossa história. O segundo motivo do por que postergamos esse desafio é que, explicar a história do ceticismo através dos conceitos principais do pragmatismo, nos pareceu ser muito mais facial rápido e eficaz.

Segundo William James (James, 2006), quando o homem pensa sobre as formas de conhecer, quando constrói uma teoria do conhecimento, adota dois tipos de postura que ele denomina de "Espírito Terno" ou racionalista, e "Espírito Duro" ou empírico. O primeiro se caracteriza por seguir "princípios" e 
tem como outras características o intelectualismo, o idealismo otimista, a religiosidade, e o dogmatismo. O segundo, ao contrário, segue fundamentalmente e apenas os fatos, é materialista, pessimista, fatalista e cético. Essas duas posições criam, para W. James, toda uma história de disputas metafísicas, na qual os "Espíritos Ternos" acreditam serem capazes de descrever o mundo como ele de fato é, e os "Espíritos Duros", declaram que devido à subjetividade dos fatos, nunca poderia ser descrito em sua verdade final. Essa última posição caracterizava os céticos. Era assim que Hume pensava, ele era um cético!

A solução do pragmatismo, de W. James, para esse dilema histórico da humanidade é muito simples: esse problema não existe! Ou melhor, ainda que exista no mundo das idéias, ele simplesmente não tem a menor importância, salvo se, em sua elaboração e discussão, algo prático possa ser derivado. Dentre os vários trechos que poderiam ser citados, um, da Segunda Conferência sobre o Pragmatismo, merece destaque: "O método pragmático é primariamente um método de assentar disputas metafísicas, que, de outro modo, se estenderiam interminavelmente. É o mundo um ou muitos? predestinado ou livre? - material ou espiritual? - eis aqui noções quaisquer das quais podem ou não valer verdadeiras para o mundo; e as disputas em relação a tais noções são intermináveis. O método pragmático nesses casos é tentar interpretar cada noção traçando as suas conseqüências práticas respectivas. Que diferença praticamente haveria para alguém se essa noção de preferência àquela outra fosse verdadeira? Se não pode ser traçada nenhuma diferença prática qualquer, então as alternativas significam praticamente a mesma coisa, e toda disputa é vã. Sempre que uma disputa é séria, devemos estar em condições de mostrar alguma diferença prática que decorra necessariamente que um lado ou outro está correto" (James, 2006).

Portanto, a primeira característica do pragmatismo pode ser descrito como: a discussão sobre a verdade de uma teoria ou idéia, só faz sentido se ela implicar uma ação prática. Agora, há outras características, particularmente duas, sobre as quais teremos que discorrer para que, a ligação entre 0 
neoliberalismo e o registro de novas drogas, possa ser estabelecida adequadamente.

O método pragmatista é essencialmente sensualista, ou seja provem fundamentalmente da observação dos. Teorias, idéias ou dogmas prévios contribuem apenas para serem questionados em suas verdades. É a observação dos fatos que constitui a essência da verdade (Shook, 2002). Não pretendo me estender muito nessa característica que se explica por si só. Antes de prosseguir, penso valer a pena fazer outra citação do W. James para defender essa posição: "A "Realidade" é, em geral, o que as verdades têm que levar em conta; e a primeira parte da realidade, desse ponto de vista, é o fluxo das sensações. As sensações são-nos forçadas, não chegando nós a conhecer de onde nos são impostas. Sobre sua natureza, ordem e quantidade, é como se não tivéssemos controle. Não são verdadeiras nem falsas; simplesmente são"

Agora a última e mais importante característica do pragmatismo: a verdade se constitui não pelos fatos observados em si, mas, da conjunção desses fatos em um formato com fins práticos. As teorias são instrumentos e não respostas aos problemas. As próprias leis da natureza se encaixam nessa observação. Segundo palavras do próprio James: "À medida, porém, que as ciências se desenvolveram, ganhou corpo a noção de que muitas, talvez todas as nossas leis são somente aproximações. As próprias leis, mais ainda, tornaram-se tão numerosas, que não há como contá-las; e tantas formulações rivais foram propostas em tantos outros ramos da ciência que os investigadores acostumaram-se à noção de que nenhuma teoria é absolutamente uma transcrição da realidade, mas que qualquer delas pode, de certo ponto de vista, ser útil. São apenas uma linguagem humana, uma taquigrafia conceitual, como se costuma chamá-las, nas quais escrevemos nossos informes sobre a natureza; e as línguas como é bem conhecido, toleram muita escolha de expressão e muitos dialetos" (James, 2006).

Portanto, para o pragmatismo, assim como para a epistemologia humiana, a relação entre os fatos, dependendo de sua utilidade, ganha status de verdade . 
Outro pequeno trecho de W. James: "A segunda parte da realidade, como alguma coisa que nossas crenças devem também levar em conta obedientemente, são as relações que prevalecem em nossas sensações ou entre suas cópias em nossos espíritos"

Por fim, para terminar essa narrativa que tenta ligar o ceticismo dos escoceses do Século XVIII (Hume, Adam Smith) com os pragmatistas norte-americanos (James, Pierce), tendo como intermediário o utilitarismo, conforme definido por J.S. Mill no Século XIX, há que mostrar a direção que as sensações tomam no espírito humano. Já apontamos para a questão da "prática" e da "utilidade", mas é preciso um reforço para que os elementos se unam. Esse reforço vem, novamente, das palavras do próprio James que diz: "Em nossa vida cognitiva ,tanto quanto em nossa vida afetiva, somos criadores. Acrescentamos parte da realidade tanto ao sujeito quanto ao predicado. $O$ mundo permanece realmente maleável, esperando receber os toques finais de nossas mãos". E para terminar: "Um universo com gente como nós contribuindo para criar sua verdade, um mundo entregue aos nossos oportunismos e aos nossos julgamentos privados" (James, 2006).

Em resumo, para os pragmatistas, e não vai aqui nenhum julgamento moral negativo, os fins justificam os meios. Há que fazer, contudo, com que, esse meio assuma um formato legível, inteligível, e, sobretudo, consensual. Talvez a mais abundante filosofia contemporânea, presente, tanto em nossa ciência quanto em nossos sentimentos morais, seja, de fato, o pragmatismo americano. Ainda que, claro, várias outras matizes de discursos filosóficos permeiem a complexa forma que nós, modernos, pensamos e agimos, considero o pragmatismo norte-americano um dos principais nortes da nossa sociedade contemporânea.

Tentaremos defender adiante a hipótese de que todo o edifício regulatório para legitimação da comercialização de uma nova droga, assim como a definição de um novo gabarito de inteligibilidade da ciência clínica contemporânea, foram construídos atendendo aos princípios morais do pragmatismo. Tentaremos defender que ambos surgiram em resposta a crises de legitimidade que 
emergiram nas décadas de sessenta e setenta. Tentaremos, finalmente, mostrar que esse novo gabarito naturalizou-se no pensamento da classe médica, e, que um processo de crítica a todo esse processo é dificultado por uma série de barreiras. 
Parte III - Ciência x Crises x Barreiras 


\section{A Emenda Keffauver-Harris - Continuação da primeira crise}

Na seção em que discutimos a história oficial da evolução do registro de novos medicamentos nos EUA e que se seguiu à análise do método de análise histórica de Hayden White, citamos a Emenda Keffauver-Harris (EKH) (Section 107 (c) of the Drug Amendments of 1962, 2009). Nessa descrição anterior, procuramos situar o foco principal dessa nova lei na questão da comprovação prévia de eficácia para que um novo registro fosse concedido. De fato, essa é a essência da nova lei, mas agora, sob um novo ponto de vista metodológico, vamos tentar analisá-la sob uma outra perspectiva histórica.

O Senhor Estes Keffauver foi um Senador americano do Partido Democrata nascido em 1903 e falecido em 1963. Ele morreu de infarto agudo do miocárdio em pleno Senado Americano. Por duas vezes tentou ser nomeado por seu partido para concorrer às eleições presidenciais, mas nunca conseguiu seu objetivo, apesar de gozar de uma grande fama popular e no meio legislativo. A notoriedade pública do Senador Keffauver não tem nada a ver com qualquer tipo de militância política relacionada à saúde pública ou ao desenvolvimento científico da medicina. Sua carreira política foi pautada sobretudo por investigações da estrutura do crime organizado, pela proteção do consumidor, e, principalmente, no final de sua vida, por uma revisão da legislação antitruste. Entre os anos de 1957 e 1963 ele presidiu um subcomitê, que se tornou muito famoso, para investigar a concentração dos recursos econômicos em alguns setores da economia americana. Entre os setores investigados estava a indústria farmacêutica. A conclusão desse trabalho foi de que esse segmento apresentava em seus balanços lucros (segundo palavras do próprio Senador) exorbitantes às custas do consumidor americano. Como derivada dessa investigação, apontou-se também para o poder de influência da indústria farmacêutica sobre as associações médicas americanas, através de patrocínios milionários, e, a manutenção de um sistema de monopólio, respaldado no arcabouço legal de proteção patentária, que impedia o acesso 
da população americana a medicamentos mais baratos e sem que tivessem um nome de marca associado a eles. A história de medicamentos genéricos nos EUA estava em sua aurora e ocorreu em paralelo com a história que é o objeto desse trabalho. Não vamos descrever em detalhes essa interessante história, mas vale destacar que ainda nessa época, final da década de cinqüenta e início da década de sessenta, não havia critérios científicos estabelecidos para se determinar e legitimar a bioequivalência entre produtos farmacêuticos. Tudo isso, como vamos ver ao longo dos próximos capítulos, estava começando a ser discutido e estabelecido a partir dessa época. (Dukes, 2005; Hutt, 1983 a, b)

Portanto, a questão do Senador Keffauver, cujo nome foi utilizado para nomear uma lei que passou a exigir o que o senso-comum hoje em dia considera como óbvio, ou seja, que uma droga nova para ser comercializada tem que mostrar previamente que é eficaz e segura na doença que está se propondo a tratar, na verdade não tinha muito a ver, pelo menos não diretamente, com as conseqüências políticas da lei que tomou o seu nome. Vejamos abaixo um pouco mais em detalhes que conseqüências são essas.

A Emenda Keffauver-Harris, ou "Drug Efficacy Amendment", é uma emenda ao Ato Fundador do FDA. Ela foi assinada contemporaneamente ao episódio da talidomida, quando milhares de crianças em vários países, principalmente na Inglaterra e na Alemanha, nasceram com graves deformidades congênitas denominadas de focomelia?.

As principais diretrizes prescritivas dessa emenda, que ainda está em pleno vigor no presente são: 1) os produtores de medicamentos têm que provar previamente a qualquer autorização de comercialização que seus produtos são eficazes no tratamento das doenças onde serão utilizados, 2) reforça a prescrição vigente desde a década de trinta, estabelecida no "Federal Food, Drug and Cosmetic Act of 1938", de que os produtores de medicamentos têm que provar que esses são seguros, e, na $\mathrm{EKH}$, passa-se a exigir que os eventos adversos de uma droga que já esteja sendo comercializada sejam obrigatoriamente reportados ao FDA, 3) a propaganda para os médicos de 
qualquer produto farmacêutico tem que explicitar claramente todos os riscos e benefícios dos produtos, 4) um consentimento formal e escrito, após 0 provimento de informações adequadas, deveriam preceder qualquer tipo de investigação clínica.

Outro aspecto interessante da EKH é a determinação de que apesar da legislação anterior ainda reservar um espaço para a liberação da autorização de um novo registro por inação do FDA após um determinado período de tempo transcorrido depois da entrega da documentação, com a nova lei, a aprovação explicita e formal, deveria necessariamente preceder em todos os casos a concessão do direito de comercialização de um produto farmacêutico.

Não há dúvidas de que essa nova emenda representou uma mudança verdadeiramente substantiva no ambiente regulatório para novas drogas nos EUA. Essa mudança trouxe algumas importantes conseqüências práticas para os vários atores envolvidos no assunto. De uma maneira geral, pode-se dizer, numa primeira aproximação interpretativa, que essas mudanças tiveram um caráter restritivo à liberdade de comercialização de novas drogas, e, ao mesmo tempo o aumento do sistema de garantia de proteção dos direitos dos consumidores de medicamentos, tanto médicos quanto pacientes.

As conseqüências práticas da EKH poderiam, a rigor, ser analisadas sob vários aspectos. Muitas dessas abordagens poderiam, por sua vez, ajudar a entender o desenvolvimento e as transformações que ocorreram na prática médica a partir dos anos sessenta, mas, por uma questão de método de análise, vamos nos concentrar em dois desses aspectos: a construção de uma racionalidade matemática para definição de eficácia e segurança em terapêutica médica e os fatores determinantes de natureza econômica que circundaram, antecederam e se seguiram à Emenda. Considero que, desses dois aspectos, importantes conseqüências, nem sempre adequadamente valorizadas do ponto de vista histórico, vieram a acontecer no terreno da prática médica.

Antes vale uma breve revisão e contextualização do que já foi descrito nas seções precedentes. A EKH surgiu em um período de início de crise econômica 
no mundo ocidental. $\mathrm{O}$ crescimento econômico que se seguiu à Segunda Guerra Mundial, impulsionado pelo Keynesianismo, e tendo como âncora a moeda norte-americana, e tendo os EUA financiado déficit crescente em suas contas, chegara finalmente ao seu limite. Esse período de grande crescimento foi acompanhado em muitos setores da economia por uma intervenção crescente do Estado que se manifestou na forma de um complexo e intenso sistema de regulamentação da economia. As agências regulatórias, em conjunto com o Poder Legislativo, aumentaram consideravelmente nessa época o controle sobre as atividades econômicas. Independentemente do partido político que estivesse no poder, a regra geral era normatizar as liberdades econômicas em nome de um maior controle do Estado e, em nome também da defesa dos direitos dos cidadãos. Reconheça-se aqui um interessante paradoxo ao conceito tradicional de liberdade nas sociedades ocidentais. Tradicionalmente para estas, liberdade era a liberdade dos agentes econômicos (e todos os cidadãos eram, por definição, agentes econômicos). $\mathrm{Na}$ medida em que o arcabouço institucional jurídico restringe, através de regulamentação, essa liberdade, a ideologia liberal perde seu norte, fica de ponta cabeça. Quanto maiores as exigências, mesmo em nome da segurança das pessoas, menor é a liberdade no sentido clássico do termo.

Vimos como, a partir do governo do Presidente Nixon, tendo seu apogeu ocorrido no governo Reagan, e sua consolidação absoluta ocorrida no período governado pelo Presidente Clinton, a noção operacional de regulamentação sofreu uma poderosa redefinição. Esta pode ser resumida na expressão: prova positiva de relação custo $x$ efetividade. Isso ocorreu em praticamente todos os segmentos da sociedade americana, do financiamento público a viagens espaciais até as regras que regulam as relações de contratos de trabalho, passando obviamente pela regulamentação do setor da saúde, e, mais especificamente, no objeto desse estudo, que são as regras de exercício da liberdade para comercialização de novas drogas.

Vimos também que essa regra de prova positiva de custo $\mathrm{x}$ efetividade segue os princípios do utilitarismo e do pragmatismo dentro da tradição clássica da filosofia anglo-saxã. O que ainda não vimos foi, como que exatamente estes 
princípios, se relacionam com a noção de cientificidade da medicina contemporânea. Esse ponto será abordado a seguir, mas antes, e se aproximando dessa questão, cumpre descrever uma outra crise que ocorreu nos anos sessenta e setenta. Esta crise, se não guarda relação direta de causalidade com a crise econômica do mesmo período, soma-se a esta no sentido de explicar, ou pelo menos ajudar a entender, o desenvolvimento ulterior da evolução da ciência médica, sobretudo em seus aspectos relacionados à terapêutica medicamentosa. Refiro-me à crise de novas descobertas em farmacologia básica.

Os anos sessenta e setenta viram minguar uma enorme proficuidade que ocorrera nas três décadas precedentes. As penicilinas, as tetraciclinas, 0 cloranfenicol, os aminoglicosídeos, a insulina, os corticosteróides, os antihistamínicos, os diuréticos tiazídicos entre muitas outras classes de drogas, já haviam sido descobertos, desenvolvidos, registrados, e estavam em plena comercialização (Cooper, 1971 a,b,c). A maioria, para não dizer todas essas drogas, haviam sido registradas com parcas (quase nenhuma para os padrões contemporâneos) evidências de natureza clínica. A medicina clínica nessa época, ainda que científica por estamento histórico estava muito longe do que hoje chamamos de Ciência Médica. Essa questão será analisada com mais rigor nas seções subseqüentes. Por enquanto importa registrar que a produtividade da ciência farmacêutica viveu, nas décadas que seguiram à $E K H$, e em plena crise de um modelo econômico que vivia seus estertores finais, um período de maré vazante, de baixa produtividade e de intenso questionamento sobre seus fundamentos e suas perspectivas futuras.

Portanto, duas crises em paralelo: uma econômica e outra científica. Ao mesmo tempo vivia-se uma situação de ter que conviver com uma alteração legislativa que impunha aos personagens que buscavam uma saída para essas crises um colossal desafio de natureza restritiva. Aqui recomeça nossa história. Pretendo mostrar como essa equação foi resolvida, como esse nó foi desatado. Sob quais princípios, de natureza ideológica, achou-se uma saída em nome da liberdade, e como essa saída, surpreendentemente, passou a ser um dos principais determinantes das próprias regras da instrumentalização e 
operacionalização do raciocínio e das tomadas de decisão médicas. Como esse novo saber clínico que emergiu dessas crises, tornou-se, ele próprio, um produto de alto valor e inquestionável credibilidade.

\section{O Caminho rumo à prova científica de eficácia e segurança de um tratamento médico - A segunda crise.}

Há um outro desdobramento da Emenda Keffauver-Harris que ainda não foi citado. Suas prescrições legislativas teriam que ser aplicadas retroativamente, isso significava dizer que: todos os produtos farmacêuticos disponíveis no mercado americano teriam que ser revistos à luz das evidências científicas disponíveis, e provar através desses dados sua eficácia e segurança. A lei teria efeito retroativo. Principalmente a eficácia, por que, como já foi dito, a prova de segurança já era uma exigência legal desde 1938. Esse assunto, do privilégio de nossa abordagem à questão da eficácia, será abordado novamente e em maiores detalhes posteriormente. Por hora basta registrar que esse trabalho de revisão foi coordenado pela Academia Americana de Ciência (National Academy of Science - NAS) e foi nomeado como "Drug Efficacy Study". Esse foi um trabalho de enormes proporções e acompanhado de perto pelo Congresso Americano, tendo durado muitos anos para ser finalizado. Terminamos a descrição da história oficial com essa informação, agora vamos aprofundá-la.

O responsável pela área de ciência médica da NAS chamava-se R. Keith Cannan. Em um painel de discussão denominado "Reliability in Product Performance in an Innovative Environment", que teve como principal orador um importantíssimo personagem para nossa história, o Professor de Farmacologia da Universidade de Georgetown chamado Christopher M. Martin (Martin, 1970). No referido debate, R. K. Cannan apresentou os seguintes números: nos dez anos precedentes àquela palestra, ou seja de 1962 até 1970, cerca de 2.200 "novas" formulações farmacêuticas tinham entrado no mercado americano. Aproximadamente dois terços desse número, ou seja aproximadamente mil e quinhentas drogas, eram apenas evidentes duplicações de drogas que já 
existiam, ou combinações de sais que já eram comercializados. Cerca de quinze por cento, ou seja, 300 a 400 eram modificações de moléculas já existentes e que ofereciam no máximo uma pequena diferença em relação ao que já era disponível há mais tempo, e, finalmente, cerca de 300 eram consideradas novas entidades que ainda, na sua maioria, teriam que provar ter verdadeiras vantagens terapêuticas no ambiente clínico. Independentemente do julgamento que contemporaneamente possamos vir a fazer sobre esses números, eles servem para demonstrar a percepção da época de que a indústria farmacêutica vivia uma crise de inovação, e também para situar a discussão, que certamente será aprofundada, e premente naquela época, sobre como descobrir novos caminhos para vencer a dificuldade de uma baixa produtividade de inovação tecnológica na área farmacêutica. Essa era uma das principais órbitas da discussão.

Esse mesmo orador diz que apesar da lei estabelecer claramente que era responsabilidade do produtor de um novo medicamento provar, com fortes evidências baseadas em estudos bem controlados, e conduzidos por investigadores experientes, todos os dizeres de marketing que esse produtor viesse a proclamar sobre o produto, a verdade é, que naquela época não havia nos Estados Unidos, nem em nenhum outro país do mundo, a quantidade de indivíduos suficientemente qualificados para realizar uma tarefa que, segundo ele, era um trabalho "intelectualmente não recompensador". Há ainda um outro ponto abordado por Cannan que acho que vale a pena mencionar antes de iniciarmos a abordagem propriamente dita, da construção do conceito de eficácia terapêutica que se construiu ao longo da década de setenta nos EUA.

Refiro-me à questão de se drogas com equivalência química poderiam ser consideradas como tendo também equivalência biológica e terapêutica. É importante esclarecer que essa discussão não se referia ainda nem à questão da definição de genéricos nem à de macromoléculas biológicas. A questão se referia a drogas de uma mesma classe terapêutica, por exemplo: um bloqueador dos canais de cálcio, ou um benzodiazepínico, nos quais, segundo Cannan, em raros casos, poderia haver uma dissociação entre 0 comportamento esperado, baseado na estrutura química, e a resposta 
biológica, ou clínico-terapêutica, observada com essas drogas. Apesar do relativamente curto espaço de tempo entre o momento em que esse trabalho está sendo escrito e a discussão capitaneada por Cannan, não há como não ficar perplexo com o fato de que, em menos de quarenta anos, essa discussão tenha se tornado tão mais sofisticada, tanto do ponto de vista científico quanto legal. Hoje em dia parece uma verdade eterna que toda molécula tem que, necessariamente, provar todas suas características, sejam químicas, farmacológicas ou clínicas. Esse fato tem um determinante.

Dentro dessa discussão há um ponto que merece destaque. Trata-se da principal conclusão do autor, que, para cumprir as exigências da lei no que tange a entrega de provas substanciais baseadas em evidências oriundas de estudos bem controlados e realizadas por investigador experiente, um produtor de um novo medicamento só irá investir recursos e dinheiro se tiver uma convicção muito forte de que realmente tem algo inovador nas mãos, e que esse novo produto poderá ter um mercado considerável e lucrativo.

Cannan, provavelmente por estar diretamente envolvido há quase uma década no projeto de reavaliação de todas as drogas comercializadas, projeto a que nos referimos antes, tinha, ao que parece, um enorme senso pragmático de interpretação de que a EKH trazia em seu ventre enormes desafios para um segmento econômico direcionado fundamentalmente pelo processo inovativo, pelas inovações tecnológicas, e que vivia, naquele momento, uma crise de produtividade sem precedentes históricos.

É importante esclarecer que os resultados práticos do referido "Drug Efficacy Study" foram bastante severos para a indústria de medicamentos. De 3443 produtos avaliados, 2225 foram considerados efetivos e cerca de 1218 considerados não efetivos para as doenças, que, em alguns casos há várias décadas vinham sendo prescritas pelos médicos americanos. Esse último número representava $35 \%$ do total dos produtos legalmente aprovados para comercialização nos EUA. Não é pouco! O destino desses produtos é surpreendente. Muitos simplesmente foram retirados do mercado. Outros como, por exemplo, as vitaminas e os fitoterápicos, passaram a ter um status 
legal diferente, paradoxalmente prescindindo de prescrição médica para que fossem comprados e consumidos. Essa é uma história paralela, com algumas intercessões, e que não será aprofundada, entretanto é interessante destacar que, a maioria absoluta desse tipo de produto farmacêutico não é passível de ser patenteável, e isso tem um significado muito especial.

O fato concreto é que somente após a EKH a prova de eficácia de uma nova droga foi colocada em questão, e que, a despeito das crises econômica e tecnológica que existiam na época, as regras da lei foram efetivamente implementadas.

A decisão de iniciar os comentários sobre o Seminário "Reliability in Product Performance in an Inovative Environment" pelo discurso proferido por um membro do NAS não foi fortuito. Esse profissional não é o mais renomado participante do evento, entretanto, sua experiência prévia no programa de revisão de eficácia, o credenciava cem por cento para ver aspectos do problema relativo à inovação na área farmacêutica sob um prisma que outros profissionais simplesmente não conseguiam ver. Alguns desses aspectos, como carência de recursos humanos e custo, já foram apontados, mas há ainda um outro importante aspecto que tem que ser mencionado.

Após um breve resumo da situação e um comentário bastante cético sobre a possibilidade da lei e do mercado se acomodarem de uma forma passiva a um novo estágio de racionalidade, ele aponta como solução uma sugestão que, posteriormente, acabou de fato sendo implementada. Nas palavras do próprio Cannan: "the obvious alternative would seem to be a greater measure of voluntary self-regulation". Ele prossegue mais adiante no mesmo texto: "we can do a better job along this road than we have in the past if we enlist the experience of medicine with the technical expertise of industry and the regulation functions of government in a spirit of cooperation rather than of confrontation".

Trata-se, na minha visão, do pragmatismo norte-americano em ação. Trata-se de como lidar com uma situação de crise olhando para a frente, libertando-se 
de verdades estabelecidas, e se disponibilizando a construir novas verdades. Veremos como se deu esse processo.

Por ser uma longa história, a abordagem direta da questão propriamente técnica dos parâmetros de cientificidade relacionados à eficácia terapêutica adotados à partir da aprovação da EKH em 1962, poderia de alguma forma comprometer o contexto histórico em que esse processo aconteceu. Em outra parte já analisamos essa história dentro dos parâmetros canônicos. Nessa ocasião registramos o fato de que a história oficial registra o fato de que um progressivo aumento da orientação de natureza científica foi aos poucos permeando as ações e decisões do FDA, à medida que a sociedade civil norteamericana tomava consciência de seus direitos. Mostramos que esse processo pode ser considerado como um "contínuo" em geral desencadeado, ou melhor, catalisado por tragédias, como a da sulfa dos anos 30 , dos barbitúricos nos anos 50, e, finalmente a da talidomida nos anos 60 . Terá sido exatamente dessa forma que as coisas aconteceram? Será possível rever essa história sob um novo e mais abrangente, menos ideologizado, ângulo? Não se pretende nesse momento rever novamente toda a história do FDA. A idéia é nos concentrarmos no período em torno da aprovação da $\mathrm{EKH}$, e tentar isolar alguns elementos que construam uma base de interpretação diferenciada em relação à história oficial que já foi contada. 


\section{Relação entre FDA e Poder Legislativo - A terceira crise}

Em 1960 um diretor da divisão de antibióticos do FDA foi acusado por um órgão de imprensa de ter relações inapropriadas com a indústria farmacêutica. Após investigação descobriu-se que esse senhor, chamado Dr. Henry Welch, havia recebido cerca de duzentos mil dólares de uma editora especializada em publicações médicas, durante os sete anos que antecederam a denúncia. Há que se considerar dois aspectos antes de seguirmos adiante. Primeiramente que duzentos mil dólares há cinqüenta anos tinha um valor de troca muito maior do que têm hoje em dia. Isso não muda nada do ponto de vista moral, mas pode ajudar a quantificar a dimensão do negócio farmacêutico. Abordaremos esse aspecto em maiores detalhes em seção posterior. Em segundo lugar, e apesar de ser um argumento um pouco sutil, é de extrema relevância, trata-se do fato de o suborno ter vindo de uma editora médica. É importante lembrar que um dos aspectos regulamentados pela EKH referia-se à propaganda médica, e, esse aspecto, apesar de não ser objeto de aprofundamento nesse trabalho teve enormes desdobramentos nos anos subseqüentes. Além disso, quando abordarmos a questão das patentes, em particular das barreiras impostas pela indústria contra a concorrência, vamos ter que revisitar a importante questão da informação médica no negócio farmacêutico (Mund, 1970).

$\mathrm{Na}$ época desse escândalo, o Senador Keffauver estava em plena atividade legislativa promovendo audiências no senado sobre preço e práticas competitivas da indústria farmacêutica. Um dos desdobramentos desse processo foi a aposentadoria precoce do Dr. Welch, o outro e muito mais importante, foi a contratação por parte do "Department of Health, Education, and Welfare" (HEW), órgão do executivo a quem o FDA estava subordinado na época, da "National Academy of Science" (NAS), para estabelecer um comitê científico para investigar a integridade das decisões científicas do órgão, e, estabelecer regras para 0 relacionamento entre o FDA e a indústria farmacêutica. Três aspectos merecem destaque para tentar amarrar a 
argumentação fundamental do trabalho: 1) registrar o fato de que foi a mesma NAS que assumiu o trabalho de revisão dos produtos disponíveis no mercado em termos de prova de eficácia de acordo com as determinações da Emenda Keffauver-Harris, 2) A conclusão do relatório foi de que as decisões científicas tomadas pelo FDA até aquele momento eram aceitáveis, e que nenhuma evidência tinha sido identificada que colocasse em risco a saúde da população americana, 3) apesar dessa conclusão o comitê fez onze recomendações, entre elas uma mudança no estatuto do FDA, dando à agência maiores poderes de controle e fiscalização, além de recomendar fortemente um reaparelhamento da sua estrutura, sobretudo aumentando seu status de cientificidade.

Esse caso, ainda que curioso por suas características novelescas, não é exatamente $O$ que representa mais fielmente 0 embate entre 0 Poder Legislativo e o FDA no período em torno da aprovação da EKH. Para desenvolver melhor esse tema, vamos dividir essa história em dois períodos: 0 primeiro que vai do início da década de sessenta o início da década de setenta, o segundo, a partir desse momento até o início dos anos noventa.

No primeiro período a tônica da discussão circulava em torno de como capacitar a agência com maiores recursos, sobretudo os de natureza científica, para que esta pudesse exercer mais adequadamente seu papel na sociedade. Em 1963, o Senador pelo Partido Democrata Hubert H. Humphrey, formado em ciências farmacêuticas e Vice-Presidente dos EUA no governo Lindon Johnson de 1963 até 1969, instituiu um processo de investigação sobre as ações do FDA, cuja conclusão foi de que a agência falhava em tomar as ações necessárias para proteger o público contra a liberação para a comercialização de drogas que eram inseguras e ineficazes.

A partir desse processo iniciou-se uma verdadeira escalada de outros processos tentando entender como se processava na vida real, na prática, o julgamento do registro de novas drogas no EUA em seus aspectos específicos, relacionados com segurança e eficácia. As discussões nesses períodos foram muito ricas e englobavam tanto aspectos gerais como particulares, assim como 
tanto aspectos técnicos como políticos. Assim, é nesse período que se sedimentou a hoje clássica divisão entre evidências clínicas de fase I, II, e III. Eminentes personagens como o farmacologista Professor Luis G. Goldman, autor de um famoso livro que todo médico conhece, recomendou que a certificação de eficácia de uma droga deveria ser sempre dada por um painel de especialistas qualificado no assunto. Os primeiros contraceptivos orais e os primeiros betabloqueadores, assim como outras drogas, passaram, após aprovação técnica pelo FDA, por uma comissão do Congresso Americano. Uma intensa discussão foi conduzida no sentido de definir parâmetros que fossem predominantemente científicos para as decisões do FDA. Nessa época, a evolução da ciência clínica, a constituição de um novo saber clínico ainda estava em seus alicerces, nos seus fundamentos.

Em 1964, montou-se no FDA um sistema integrado de informação científica, e este teve como resultante a já referida classificação dos estudos clínicos, e um sistema racional e reprodutível para o relato de eventos adversos. Este, posteriormente, cresceu substancialmente, sendo hoje em dia definitivamente uma referência teórica e prática do controle de segurança para medicamentos para todos os países do mundo.

Já nesse período começam também, ainda timidamente, as primeiras manifestações de que um excesso de burocracia poderia inibir 0 desenvolvimento científico e o processo de inovação na área terapêutica. Um eminente personagem, que depois se tornaria um dos principais protagonistas da segunda fase, o Professor de Farmacologia da Faculdade de Medicina da Universidade John Hopkins, em conferência proferida na Casa Branca, exorta o Governo a estimular uma maior cooperação entre a indústria farmacêutica e os cientistas que trabalhavam nas universidades, no sentido de se buscar melhores soluções para o tratamento medicamentoso das doenças crônicas. Ele alerta para o risco do excesso de exigências burocráticas impedir a realização desse objetivo.

Foram vários os relatórios escritos nessa época, ao longo da década de 60, cuja conclusão era, como já foi dito, aumentar a capacitação científica do FDA. 
Para encerrar esse assunto, destaco o denominado "Kinslow Report" que teve como principal recomendação: "fortalecer o FDA em suas principais competências científicas, particularmente nas áreas de farmacologia básica e em estudos clínicos de drogas" (Hutt, 1984 a).

A partir do início da década de 70 a retórica do discurso começa a mudar. No início de 1972, Dr. Robert Dripps, anestesista, Vice-Presidente de assuntos médicos da Universidade da Pensilvânia, escreveu uma carta para o Deputado do Partido Democrata, o Sr. Paul G. Rogers, dizendo que o processo de revisão para registro de novas drogas que estava sendo adotado nos EUA estava fazendo o país perder a competitividade em relação a outros países do mundo. A questão que ele queria destacar não era apenas econômica, na realidade sua preocupação principal era 0 atraso científico no que tange 0 desenvolvimento de novas soluções terapêuticas. Outros vinte e um cientistas assinaram essa carta.

Esse documento desencadeou uma discussão que se arrasta até os dias de hoje, e que, na época ganhou a denominação de "drug lag". O fulcro dessa discussão era (e ainda é) estimar o quanto da regulamentação sobre a liberação de novas drogas para comercialização nos EUA, que estava em pleno processo de germinação, e que tinha como fundamento o aumento das competências científicas do FDA, era de fato válido numa perspectiva mais ampla de toda a sociedade. Tratava-se do início da discussão na área da saúde, ou pelo menos na área de novas propostas terapêuticas com medicamentos, sobre a equação custo $\mathrm{x}$ benefício. Já discutimos com alguns detalhes quando estabelecemos as relações entre a arte de governar neoliberal norte-americana, organizada em torno do OMB, que a solução dessa equação era a palavra de ordem a ser seguida. A discussão em torno do "drug lag" era a matéria em torno da qual orbitavam todas as discussões, fossem elas de natureza científica, tecnológica, burocrática, legal, e principalmente como veremos adiante, econômicas (Hutt, 1984 b).

No final de 1972 o mesmo economista que já foi citado quando discutimos as relações entre o neoliberalismo e o utilitarismo, o Sr. Sam Peltzman, da 
Universidade de Chicago, proferiu uma conferência que teve ampla repercussão na mídia, e cuja conclusão foi de que os custos embutidos na EKH excediam substancialmente os benefícios que poderiam ser divididos pela sociedade (Peltzman, 1974). O interessante é que, nessa época, sequer estavam determinadas as regras técnico-operacionais que fossem consideradas consensuais entre todos os participantes do diálogo (FDA, indústria farmacêutica, comunidade científica, e sociedade civil) sobre o que e como julgar uma nova droga como eficaz e segura do ponto de vista científico. Esse é um ponto extremamente importante e será discutido em mais detalhes nos itens seguintes. Por enquanto basta registrar dois fatos e depois fazer duas perguntas

Primeiro os fatos: 1) para um olhar contemporâneo o custo de desenvolvimento de uma nova droga nos anos setenta era consideravelmente menor do que 0 custo atual, 2) Nessa época, a maioria absoluta dos estudos clínicos apresentados pelas empresas farmacêuticas para registro de novas drogas eram apenas observações abertas e não controladas. Agora as perguntas: 1) se no início da década de setenta, os parâmetros de cientificidade para o registro de novas drogas ainda eram predominantemente de natureza farmacológica, e o método de avaliação científica de uma decisão médica sobre tratamento era exclusivamente de observação não controlada, como será que eram tomadas as decisões médicas na prática clínica? 2) Será que realmente, de lá pra cá, com a implementação de uma nova forma de pensar e dirimir as dúvidas clínicas, com a constituição de um novo saber médico, houve uma grande mudança, no sentido de melhora, da capacidade do médico praticante de resolver os problemas trazidos pelos seus pacientes?

Outros economistas cerraram fileiras com Sam Peltzman na defesa da tese de que 0 excesso de regulamentação na área de novos medicamentos era contraproducentes para a área de saúde pública, por restringir o acesso dos pacientes às novas tecnologias e ao desenvolvimento tecnológico, por impor custos excessivamente altos, com poucas chances de obtenção de retorno, aos agentes financiadores de investimentos em inovação farmacológica, no caso específico, a indústria farmacêutica. 
Citam-se, a título de ilustração do trabalho, o Dr. David Schwartzman, Professor de Economia da "New School of Social Research", que publicou um livro sobre o problema da inovação no ambiente da indústria farmacêutica, e o Professor Henry Grabowski, da Duke University, que publicou um importante artigo sobre o mesmo tema. Não analisamos em profundidade esses trabalhos. $\mathrm{Na}$ realidade, há toda uma literatura sobre o "Drug Lag ". Essa literatura teve início no começo da década de setenta e se estende até os dias de hoje. É produzida principalmente por economistas e juristas, e suas conclusões são, de alguma forma, bastante monótonas, tendendo sempre para o ponto de que a busca por critérios empíricos de certeza de eficácia e segurança de uma nova droga incorpora custos ao processo como um todo que são muito maiores do que o benefício final resultante para toda a sociedade.

Soma-se, portanto, à crise econômica e à crise científica, ambas já discutidas, uma outra crise, esta de certa forma tributária das outras duas, e que poderíamos chamar de institucional.

É claro que essa divisão temporal que foi apresentada sobre a crise institucional é apenas didática. Na verdade, em plena discussão sobre o "Drug Lag" e sobre a relação custo $x$ efetividade dos processos técnicos para registro de novos medicamentos, o embate sobre o papel que o FDA deveria exercer em todo o processo sempre continuou. Em meados da década de 70 aconteceu uma célebre audiência no senado promovida pelo igualmente célebre Senador Robert Kennedy, que, de certa forma, mudou o rumo da legislação sobre genéricos, sobre o reporte e análise de eventos adversos das drogas comercializadas, e cuja conclusão bombástica foi de que o FDA era dominado pela indústria farmacêutica e de que não estava exercendo eficientemente o seu papel de proteger a população dos EUA, contra a liberação para comercialização de novos produtos farmacêuticos. Estes, segundo a conclusão dessa audiência, estavam sendo aprovados, apesar de serem ineficazes e inseguros (Hutt, 1984 b). 
Mas voltemos ao início. Em 1962 foi aprovada uma lei que exigia provas sólidas de eficácia e segurança de uma droga fossem apresentadas ao FDA antes que sua liberação para comercialização e marketing fosse aprovada. Dez anos depois, no início da década de 70 , como estava essa discussão? Tentaremos descrever nos parágrafos abaixo como a discussão sobre os parâmetros racionais de para definição de efetividade terapêutica, baseados em estudos controlados e comparativos, foram efetivamente construídos ao longo do período estudado, e como essa discussão aparentemente apenas técnica, se mistura e se confunde com a necessidade de se construir uma nova ordem institucional e uma nova racionalidade com, na minha opinião, profundas influências sobre a prática médica que se constituiu posteriormente. 


\section{A Racionalidade dos critérios científicos de eficácia}

Christopher Martin, Professor de Medicina, diretor do Laboratório de Farmacologia Clínica da Universidade de Georgetown, e, posteriormente membro da Merck Sharp \& Dohme Research Laboratory, foi o orador principal de uma outra discussão, já referida anteriormente e denominada "Reliability in Product Performance in an Innovative Environment" (Martin, 1970). Alguns pontos dessa palestra serão descritos com o objetivo de mostrar que, no início da década de 70, ainda estávamos muito longe do que acabou se constituindo como o atual sistema de racionalidade para definição de uma racionalidade científica.

O autor inicia sua argumentação atestando que o FDA goza de grande credibilidade junto à sociedade americana de uma maneira geral, e junto à classe médica em particular. Diz que, historicamente, se uma droga ganha o status de aprovação por esse órgão, isso praticamente significa que a população pode se sentir segura. Diz também que as indústrias farmacêuticas se esmeram continuamente no sentido de garantir qualidade aos produtos e de promover o desenvolvimento científico e tecnológico da medicina. Além de prover a comunidade com experiência e recursos para um ambiente de inovação na área terapêutica. Após essa introdução, que deve ter deixado todo mundo feliz e confortável, conseqüentemente desarmado, ele começa a expor seu verdadeiro argumento central.

Cada vez mais a comunidade médica estava se tornando cética e desconfortável com as decisões tomadas pelo FDA. Os resultados, naquela época ainda parciais do trabalho empreendido pelo National Academy of Science, de revisão das evidências de eficácia das drogas aprovadas antes de 1962, com a proibição da comercialização de várias combinações de antibióticos e analgésicos, entre outras drogas amplamente prescritas e consumidas, colocava efetivamente todo o processo em um tipo de suspeita ou pelo menos de uma demanda de revisão sob um novo prisma. E que prisma 
exatamente era esse? Para tentar responder a essa pergunta, apelo para as palavras do próprio autor, e, no original em inglês, para evitar dúvidas de interpretação e de tradução. Assim escreveu o Professor C. Martin: "It is important to note that the issue in each of these examples almost invariably hinges, in more or less degree, upon the nature and quality of the data which the benefit-to-risk ratio of a drug was originally estimated. Repeatedly, the issue turns upon efficacy data of ambiguous significance or toxicity observation which, though extensive, have missed the point". Outro trecho: "The element common to each of these examples, is the paucity of controlled clinical data of high quality, a deficiency which indicates some significant scientific limitation of industrial sponsor, clinical investigators and Federal Evaluators". "The Achilles heel of the system, however, is the nature and quality of data describing the beneficial and adverse effects of the new drugs in man. Repeatedly, the data submitted in support of New Drug Application ignore a basic principle of applied medical research: the art of clinical investigation of effects of drug in man consists of disciplined pursuit of systematic comparison under operational clinical conditions" (Martin, 1970).

Trata-se, a meu ver, de um apelo a um só tempo elegante e dramático para uma revisão de como se deve tomar uma decisão médica, e talvez a mais importante de suas vertentes, que é terapêutica, sob o ponto de vista da racionalidade científica. Aqui aproveito para apontar para o fato de que essa mesma racionalidade já tinha sido estabelecida cerca de oito anos desde a publicação na revista "Annals of Internal Medicine" dos artigos originais do médico epidemiologista americano Alvin Feinstein. Será que havia um desacoplamento entre a ciência médica conforme praticada e teorizada no seu dia a dia, ou no seu ambiente acadêmico, e aquela praticada pelos investigadores de novas drogas, de maneira que, fora do ambiente regulatório, a "arte da investigação clínica" era já, naquela época, praticada na forma de uma busca disciplinada por um processo comparativo sistemático dentro de condições clínicas operacionais, conforme descrito por C. Martin? Antecipo que não há na literatura pesquisada nenhuma evidência disso! Ao contrário, tudo aponta para o fato de que esta arte da investigação clínica, independentemente de onde busquemos sua origem teórica, e nesse exercício uma imaginação 
fértil pode-se seguramente chegar até Hipócrates, tudo indica que a implementação de fato dessa metodologia nasceu como uma necessidade imposta por um período muito particular da história da medicina e que, mais importante do que isso ganhou um apoio quase incondicional por parte da comunidade médica e científica, por parte da indústria farmacêutica, por parte do FDA, e finalmente por parte da sociedade civil como um todo.

Mais adiante serão construídos argumentos para explicar esse sucesso. Há, na minha opinião, uma razão imediata para isso. Ainda que o desenvolvimento científico na Medicina, e o apuro estético matemático da teoria que circula em torno do que se chama genericamente de Epidemiologia Clínica, sejam sem dúvidas, fatores que podem compor a cesta de um rol de argumentos, há uma outra causa mais premente e que será descrita em maiores detalhes em capítulos posteriores. Há uma questão principal em todo esse processo histórico! Antes de abordá-la será feito um breve sumário de como ocorreu a aurora dessa nova racionalidade com dados empíricos reais. 


\section{A questão de cientificidade dos dados. A prova de segurança e eficácia de uma nova droga.}

Seguindo a linha de raciocínio descrita na seção precedente, C. Martin, no mesmo texto, se pergunta: Por que os dados clínicos apresentados ao FDA continuam sendo apenas relatos individuais de centenas de casos sem controle? Serão os dados resultantes de pacientes avaliados de uma forma tão não controlada uma base adequada para se estimar a relação custo benefício de uma droga? Portanto, em 1970 não só não havia uma base de experiência para realização de ensaios clínicos controlados, como estes sequer eram uma exigência formal que garantisse o que, na realidade, a lei já exigia. Apesar de, aos olhos contemporâneos, isso soar um pouco estranho, há menos de quarenta anos um estudo clínico controlado estava longe de ser hegemônica e consensualmente considerado por todos os médicos e legisladores como um paradigma de racionalidade que estabelecesse uma distinção clara entre uma decisão médica caracterizada como científica, ou outra considerada apenas como intuitiva ou não científica. Defendo a tese que foi nessa época, pressionado por demandas legais, e se adaptando a uma nova situação econômica de crise, que esse novo paradigma foi estabelecido. Há aqui uma ruptura, e é a dissecação desta ruptura que estamos tentando realizar.

Antes de passarmos para a questão fundamental, vale uma breve descrição da magnitude do uso da nova racionalidade em meados da década de 70 . Não parece haver dúvida de que o princípio normativo fundamental do método científico estava estabelecido. Era claro, pelo menos para os defensores do método, de que a única forma científica para se dirimir uma dúvida clínica sobre segurança e eficácia de um tratamento era através de dados comparativos e bem controlados. O resto era mistificação, apenas um conhecimento pré-científico, que apesar de evidente para os defensores do método, estes ainda se empenhavam em uma luta política para serem ouvidos. Serão descritos dois estudos realizados de forma cientificamente correta. 
O primeiro visava identificar se a associação rifampicina-estreptomicina era mais segura do ponto de vista de hepatotoxicidade do que a associação já conhecida e mais convencional de isoniazida-estreptomicina. Foram avaliados quatorze pacientes, sete em cada grupo, e, as conclusões foram que não havia diferença entre os dois grupos. Esse estudo de proporções modestas, para dizer o mínimo, foi considerado suficiente como prova positiva de relação riscoefetividade para a associação rifampicina-estreptomicina. Isso porque, junto com a análise de segurança hepática, avaliou-se também a positividade das culturas de escarro dos pacientes incluídos no estudo. Os resultados são muito interessantes. No período pré-tratamento as sete culturas de cada grupo eram positivas, um mês após o início do tratamento, cinco em cada grupo eram positivas. Dois meses após o início apenas uma era positiva no grupo rifampicina-estreptomicina e quatro permaneceram positivas no outro grupo. Ao final de três meses o grupo rifampicina-estreptomicina permanecia com uma cultura positiva enquanto o outro grupo mantinha três culturas positivas. Apesar de ingênuos aos olhos modernos, esses dados foram suficientes para atestar uma tendência de superioridade da rifampicina em relação à isoniazida, ambos associados a estreptomicina, no tratamento da tuberculose pulmonar.

Importa nesse caso descrever mais o método do que questionar a validade dos seus resultados. Importa apontar para o fato de que foi o produtor da rifampicina que procurou o laboratório de Farmacologia Clínica do Professor C. Martin para produzir dados científicos sobre a segurança e eficácia de sua droga a fim de obter aprovação de comercialização. Importa mostrar o nascimento de uma nova racionalidade na medicina.

O outro estudo é também muito interessante. Seu objetivo principal era analisar a eficácia de seis diferentes esquemas terapêuticos para o tratamento de infecções graves causadas por bactérias Gram negativas. Noventa pacientes foram distribuídos em seis grupos, a saber: cefaloridina-polimixina B, cefaloridina-colistina, gentamicina isolada, gentamicina-cefaloridinakanamicina-polimixina $B$ e por último, kanamicina-colistina. A descrição dos resultados é um pouco confusa, mas a conclusão mais importante do estudo é a de que os grupos tratados com gentamicina tinham tido uma mortalidade de 
$15 \%$, enquanto todos os outros grupos tinham em seu conjunto, uma mortalidade de $32 \%$. Nesse estudo os autores fazem questão de destacar que seus resultados atingiram significância estatística ao nível de 0,05. Portanto, em relação ao estudo anterior este apresenta uma espécie de diferencial legitimador: uma significância estatística!

Não se pretende com esses exemplos provar que, pela primeira vez na história, se fez um estudo controlado de terapêutica médica ou que pela primeira vez se tenha utilizado instrumentos estatísticos de testes de hipóteses em situações clínicas. A idéia não é buscar a origem primeira de um método que a partir daí só se aprimorou. A idéia é apontar para o fato de que em meados da década de 70 , essa racionalidade, que hoje é considerada como praticamente hegemônica no raciocínio médico, tinha que, a duras penas, provar sua validade, sua legitimidade.

Nesse sentido, vale a pena recorrer às palavras do Prof. C. Martin: "Why is not possible to conduct similar controlled trials - under operational clinical conditions, and preferably on a combined, cooperative, multi-institutional basis with all new drugs in which preliminary toxicology and efficacy studies permit them?". A história mostrou que essa idéia não só era possível, mas foi exatamente o que aconteceu. Mas quem articulou a solução? Quem afinal pagou pelo almoço? Estamos nos aproximando da questão principal.

Antes de abordarmos de frente a questão principal, vamos ver as respostas que o próprio Prof. C. Martin aponta para suas interrogações, e, algumas reverberações de sua proposta.

Michel Foucault, em um texto genial intitulado "Histórias de Homens Infames" (Foucault, 2005c), defende a controvertida tese de que personagens esquecidos pela história (loucos, criminosos, parias de uma maneira geral), tinham que ter as suas vozes ouvidas pela posteridade, de que seus discursos produzem tanta verdade quanto os textos canônicos de referência histórica. Longe de mim sugerir que o Prof. C. Martin é um homem infame, mas penso que a profundidade de sua análise, aliada à realização efetiva posterior de suas 
sugestões, contrastam com a importância conforme descrita na história canônica da medicina contemporânea. Ele é quase um esquecido!

A primeira resposta dada pelo Prof. Martin é de que a pesquisa clínica relacionada a novas drogas era cautelosamente evitada pelos médicos cientistas americanos, e que isso se devia a basicamente três fatores: 1) o interesse exclusiva, ou, predominantemente, comercial desse tipo de pesquisa, 2) pelo fato de não haver incentivos por parte de organizações com maior credibilidade, como o National Institute of Health $(\mathrm{NIH})$ ou mesmo o FDA, para treinamento de investigadores, ou a realização de investigações desse tipo, em um alto padrão, 3) por último, aponta para o fato de que o FDA, não necessariamente, saberia como reconhecer um trabalho de qualidade científica realmente superior, exercendo seus técnicos, na maioria das vezes, apenas um exercício inútil de crítica burocrática.

Segue a esse início de abordagem pragmática e pontual para o problema da falta de estudos controlados nos EUA, o autor aborda diretamente a já referida "drug lag". Apesar do fato de que a existência mesma desse problema ser objeto de discussão, e principalmente de as conseqüências de sua eventual existência para o conjunto da saúde da população americana ser ainda objeto de polêmica, C. M. Martin atesta claramente que a maioria das novas drogas introduzidas nos EUA após 1962 já vinha sendo legalmente comercializada nos países europeus, há vários meses (ou até anos) antes da aprovação nos EUA. A questão do "drug lag" volta à cena.

Após essas definições e respostas iniciais, a argumentação avança no sentido de identificar como um dos responsáveis pelos problemas, tanto da má qualidade da pesquisa clínica nos EUA, quanto do "drug lag", o caráter estatutário do FDA, que, por ser uma agência puramente regulatória e burocrática, carece de capacitação técnica e pessoal especializado para efetivamente contribuir de forma positiva para o processo geral de inovação tecnológica na área de novos medicamentos. Isso faz com que, quando um avaliador do FDA tem que tomar uma decisão que envolva pressupostos científicos, ele necessariamente se torna lento e vacilante. Paradoxalmente as 
pessoas mais capacitadas para conduzir o processo, que segundo o autor era a comunidade científica universitária, a mesma que momentos antes ele apontara como despreparada para realização de estudos clínicos de alto nível, era alijada do processo decisório.

A solução para essa situação paradoxal ganha um rumo, a partir desse momento, extremamente interessante. Após uma análise de três importantes experiências históricas a saber:

O processo decisório de natureza pragmática e consensual que já havia sido implementado pelo National Institute of Health (NIH). Nas palavras do autor "by developing pragmatic, democratic consensus mechanisms for sharing a small, but crucial fraction of its responsibilities with non Federal Scientists and citizens, $\mathrm{NIH}$ has progressively broaded its responsabilities and achievements to a degree unmatched even in highly centralized, non-democratic societies". A já (por duas vezes) referida experiência da National Academic of Science, na tarefa de rever os critérios de eficácia de todas as drogas autorizadas antes de 1962, quando um trabalho de negociação e cooperação entre todas as partes envolvidas concluiu pela necessidade de se criar, não só comitês específicos de análises em várias áreas de especialidades médicas, como também padronizações ainda não existentes de metodologia científica tanto para estudos clínicos como também para avaliação de toxicologia animal.

A última referência para solução da situação paradoxal da existência de uma agência burocrática não capacitada tecnicamente, e uma comunidade científica não participante, é uma experiência vivida no Reino Unido e que se chamava de "Dunlop Committee". Tratava-se, em última instância, de um comitê instituído pelo Ministério da Saúde Britânico para avaliação da segurança das drogas comercializadas naquele país. Esse comitê tinha duas características ainda não apontadas, e que, segundo o Prof. Martin, deveriam ser consideradas: primeiramente a colaboração com a indústria farmacêutica inglesa, que com seu poder econômico, iria patrocinar os estudos necessários para prover dados de evidências científicas sobre as novas drogas. Em segundo lugar, o fato de que todas as decisões tomadas por aquele respeitado 
comitê deveriam ser baseadas em estudos clínicos controlados. É importante dizer que o "Dunlop Committee" era composto rigorosamente por cientistas ligados às universidades inglesas, não era renumerado, era extremamente respeitado pela sociedade e, finalmente, suas deliberações em geral eram acatadas pelo Ministério da Saúde inglês, que, em última instância, era o comprador das novas drogas.

Baseado nessas três experiências, o Prof. Martin desenha sua proposta de solução, que basicamente é a constituição de comitês de especialistas, de caráter não estatutário, semelhantes aos já existentes na época do $\mathrm{NIH}$, que deveriam funcionar como conselheiros, tanto do FDA quanto da indústria farmacêutica nos assuntos técnicos relacionados ao tipo de dados que seriam exigidos para se certificar a liberação para comercialização de uma nova droga. A proposta não é obviamente desenvolvida em seus detalhes operacionais, uma vez que ela implicava em mudanças de funcionamento de órgãos públicos e privados e em procedimentos já vigentes e consolidados por lei. Mas ela aponta para a direção para a qual o processo iria de fato correr.

Há outro protagonista nessa história cujas reflexões sobre o assunto merecem alguns comentários. Seu nome: Prof. Louis Lasagna. Ele era médico e farmacologista. Ao contrário do Prof. Martin, o Prof. Lasagna consta nos anais oficiais da história da reformulação dos critérios de cientificidade para determinação da eficácia de uma proposta terapêutica como um verdadeiro protagonista. Ele foi da John Hopkins University, até 1970, onde fundou o primeiro departamento de Farmacologia Clínica dos Estados Unidos, e depois migrou para a Universidade de Rochester, onde, como chefe do Departamento de Farmacologia e Toxicologia, fundou o Centro para Estudo do Desenvolvimento de Drogas. Prof. Lasagna teve um papel de destaque na aprovação da emenda Keffauver-Harris e militou durante toda a sua vida no sentido de construir uma base mais racional para as decisões médicas. Ele é o autor de uma famosa versão atualizada do juramento de Hipócrates, um verdadeiro libelo à arte humanística da Medicina. 
Prof. Lasagna foi o orador principal em um debate intitulado: "Constraints on innovation in Drug Development and Use" (Lasagna, 1970). Dono de um evidente senso de humor e grande habilidade discursiva, ele aborda o assunto enumerando sete questões fundamentais, que, segundo ele, deveriam ser endereçadas para se incentivar o desenvolvimento de novas drogas. Antes de enumerar esses sete pontos, contudo, ele faz uma introdução na qual denuncia a falta de um diálogo efetivo entre os Departamentos de Farmacologia das Universidades e as fontes financiadoras de pesquisas em novas drogas, entenda-se, a indústria farmacêutica, como um dos principais responsáveis pelas dificuldades encontradas pela sociedade na busca de inovações farmacêuticas. Ele faz esse comentário, mas sob a perspectiva de seu lado da equação, dos departamentos de farmacologia. Ele se posiciona do lado do mundo acadêmico americano.

Em linhas gerais ele exorta a comunidade científica a abandonar o que ele chamava de "Niilismo Terapêutico", e a entender que o enorme sucesso que a descoberta de novas drogas efetuada pela indústria farmacêuticas nos últimos anos deveria ser aproveitada por essa comunidade, e que o criticismo excessivo, assim como a constante acusação de comercialismo, em nada ajudava na busca por novas soluções terapêuticas. Aponta também para outros interessantes fatos como, por exemplo, a relativa ineficiência da busca cega por novos receptores de ação farmacológica, ou mecanismos de ação diferentes de novas moléculas, e, num jogo de linguagem, sugere que uma busca cega, desde que esta fosse mais direcionada, o que significa dizer, associada a estudos clínicos cegos e comparativos, poderia aumentar a eficácia do processo como um todo.

O tom do seu discurso, ao contrário do Prof. C. Martin, que ainda tentava provar que uma metodologia analítica quantitativa adequada ao problema da clínica deveria ser implementada, é de que isso é mais do que óbvio. Essa tomada de posição o faz avançar em dois pontos que são extremamente importantes para o nosso trabalho: 1) a defesa da maior utilização de dados clínicos de eficácia e segurança provenientes de investigadores clínicos de outros países que não os EUA, o que para ele era evidente, desde que os 
dados tivessem sido colhidos de forma homogênea e através de um método padronizado, com uma regra pré-estabelecida, com uma etiqueta de comportamento. Nessas condições as informações poderiam ser universalizáveis. Voltaremos a essa questão quando formos analisar o que significam as Boas Práticas Clínicas, 2) que não há nenhum problema a priori com a propaganda de informações sobre as características e benefícios de uma droga, leia-se instrumentos de marketing farmacêutico, desde de que esta seja fundamentada em dados científicos controlados e colhidos de forma ética, e, que essa divulgação, resulte em benefício para toda a comunidade.

O texto do Prof. Lasagna é cheio de idéias e de difícil interpretação. Os argumentos são um pouco circulares, e, é evidente o cuidado que procura tomar, para não aprofundar questões polêmicas. Mas, de uma maneira geral pode-se dizer que há uma defesa forte do papel do que ele denominava farmacologia clínica no processo decisório de legitimação científica de uma droga, seja do ponto de vista de eficácia ou de segurança.

Dos sete pontos referidos pelo Prof. Lasagna como fundamentais para se entender as restrições à busca de inovações, os quatro mais importantes para defesa de nossos objetivos serão descritos:

O primeiro é a já referida por outro autor, falta de comunicação entre as partes envolvidas e com interesses no processo regulatório: reguladores, indústria farmacêutica e academia científica. Através de vários exemplos, ele mostra que a melhora na comunicação facilitaria o trabalho das três partes em benefício de toda a sociedade. A segunda e interessante questão que ele aponta, esta mais relacionada com problemas de caráter metodológico, é o uso da nascente, à época, ciência da computação para melhorar a acurácia científica dos dados clínicos. Ele cita, por exemplo, a estratificação dos pacientes por grupos mais homogêneos antes de se medir qualquer resposta a uma intervenção. A terceira questão que ele aponta é o grau de transparência relativo ao processo decisório por parte do FDA. Sua questão fundamental, embora ele não a diga exatamente da forma como vou descrever, é que, se os critérios de decisão fossem absolutamente científicos em sua essência, em tese, qualquer pessoa 
poderia produzir um julgamento neutro, e, eventualmente, propor melhoras. A quarta e última questão, que na realidade é apenas mencionada, e sobre a qual produziremos uma discussão mais aprofundada em parágrafos posteriores, em um capítulo à parte, é a questão do financiamento das pesquisas, e assuntos correlatos como incentivos fiscais, contratos, etc...

Finalmente, conclui o texto na tentativa de construir um ponto comum entre todos, dizendo: "with most constraints we will find a picture in runny water colors, rather than sharply etched print. And it is in just such situations that men of good will must weigh the pros and cons of alternative courses of social action and select the path of that seems wisest, being always ready to shift course if we are proved wrong by experience".

Nesse importante debate, vários participantes apresentaram interessantes contribuições, mas, um deles merece destaque. Trata-se do Vice-Presidente de Pesquisa e Desenvolvimento da Merck \& Co., o Dr. Antonie T. Knoopers.

Se de dentro da posição compartilhada por quase todos da necessidade de integrar indústria farmacêutica, reguladores e comunidade científica acadêmica, o Prof. Lasagna assumiu a posição da última, para tentar chegar a um meio do caminho, o Dr. A.T. Knoopers, parte da perspectiva da indústria, visando exatamente o mesmo objetivo.

Seu discurso começa pela descrição de dois fatos que, segundo ele, deveriam ser assumidos como verdadeiros, antes que qualquer proposta de solução fosse feita. O primeiro ponto é o de que a capacidade de inovação em drogas de prescrição vivia uma crise séria, e sem precedentes, ao longo dos anos sessenta e setenta nos EUA. Crise essa, na sua interpretação do significado da palavra, nos dois sentidos que, segundo ele, ela comporta, a saber, no sentido clássico, ou seja, de julgamento, e no sentido moderno, de estresse e preocupação. O segundo ponto é o de que, técnicas inovadoras que buscassem novas soluções terapêuticas eram imperativas. $O$ antigo modelo não mais se adequava às novas necessidades e regras da sociedade. 
A partir dessas observações, desenvolve então uma interessante linha de argumentação, dizendo que, mesmo as drogas que já estavam no mercado, necessitavam de melhoras, necessitavam de incrementos. A própria crescente demanda por melhores condições de saúde proveniente da população americana, que era direcionada para a comunidade científica e para indústria farmacêutica, impunha a esses agentes a busca por melhores soluções, mesmo em condições para as quais alguma solução já era disponível. Não há como negar que se trata de um ponto de vista inquestionável, mas que nem sempre é pensado com tanta objetividade, quando se discute inovação tecnológica na área de medicamentos. Prossegue, então, o Dr. Knooper, em sua argumentação, porém fazendo um desvio de rumo no sentido de perguntar se os processos políticos, sociais e econômicos, que estavam em curso nos Estados Unidos naqueles tempos, iriam ter como resultante a continuidade da tradição histórica do país de promoção do desenvolvimento tecnológico e da busca incessante de inovações, ou se as propostas que estavam sendo discutidas, a respeito da mudança na lei de patente, e a construção de um processo regulatório cada vez mais complicado, com custos cada vez maiores e riscos cada vez mais difíceis de calcular, e, finalmente, com incentivos cada vez mais incertos, se todas essas alterações em conjunto, não iriam mudar a concepção geral de inovação na sociedade americana, que migraria de um foco predominantemente direcionado para a inovação, em direção a outro foco que seria o suprimento universal de "commodity". Esse era o posicionamento do Dr. Knoopers. Difícil ser mais claro. Com a descrição desse comentário, aproximamo-nos consideravelmente da questão principal.

Após essa introdução ao problema geral da inovação em medicamentos, ele introduz a questão mais específica da área de descobertas em terapêutica medicamentosa. Define inovação como uma concepção, produção e marketing de uma melhora qualquer. A diferença da indústria farmacêutica para a maior parte dos outros segmentos da economia é que, do processo de invenção, da descoberta ou síntese de uma nova molécula até o desenvolvimento final do produto farmacêutico, o processo não segue 0 modelo tradicional da abordagem edisoniana. Este processo caracteriza-se pela combinação racional de tecnologias disponíveis com o objetivo de se conceber uma idéia mais 
ampla e poderosa, que acaba por conduzir ao desenvolvimento de um novo produto. Esse é o modelo, segundo Dr. Knooper, da maior parte das indústrias que se caracterizam por um alto grau de incorporação tecnológica, e cujos produtos têm que ser inovadores. $\mathrm{Na}$ indústria farmacêutica, entretanto, o modelo é diferente, a inovação na área farmacêutica é resultante principalmente de uma abordagem empírica e depende de um sistema de tentativa e erro.

Prossegue na argumentação dizendo que, às vezes, uma molécula inovadora do ponto de vista de sua ação farmacológica, acaba se mostrando inviável devido a seus efeitos colaterais, quando administrada de forma prolongada a um paciente portador de uma doença crônica. Segundo ele, essa era mais uma regra do que uma exceção, e que, para quem não conhece os detalhes de uma operação de pesquisa e desenvolvimento de uma nova droga, aparentemente poderia parecer que há muito desperdício de recursos, mas, na realidade o que acontece é que o processo de tentativa e erro é realmente muito caro.

Essa discussão introduz ao assunto das drogas semelhantes, em inglês chamadas "me too drugs". Havia na época, e ainda há, muita crítica com relação a drogas novas de uma mesma classe terapêutica já disponível. $O$ próprio Dr. Knoopers reconhece que um marketing muito agressivo, mesmo, e talvez principalmente, quando eficiente, desse tipo de droga, pode ser constrangedor tanto para indústria farmacêutica quanto para a comunidade médica. Mas diz que, dado as características de imprevisibilidade do desenvolvimento farmacêutico, e aos altos custos de todo o processo, nenhuma indústria se lançaria no processo de desenvolvimento uma nova droga sem a pressuposição prévia de que essa nova e diferente molécula, não iria representar um ganho em termos de algum benefício para o paciente. Se ao final do desenvolvimento esse benefício não se confirmasse, isso era um desfecho não esperado e até indesejável. Veremos adiante quando abordarmos a questão do monopólio, que essa argumentação pode ser apenas parcialmente verdadeira. 
Apesar de todas essa dificuldades o Dr. Knoopers afirma, e com uma certa razão, que do ponto de vista de novas descobertas, a indústria farmacêutica tinha sido extraordinariamente bem sucedida desde a Segunda Grande Guerra. Afirmava também que muito poucos segmentos poderiam exibir um portfólio de sucessos tão vasto, e que, as críticas que recebia eram mais pelos lucros dos seus sucessos do que pela incapacidade de suas realizações. A questão era, como já foi dito, que, naquele momento, as condições haviam mudado e não se sabia ao certo, exatamente como continuar com a mesma taxa de sucesso. Era esse o problema que demandava um equacionamento: como continuar sendo bem sucedido em termos de resultados operacionais no seio de uma sociedade que estava demandando mais segurança, preços menores, e que parecia disposta a reduzir os incentivos disponíveis para a iniciativa privada?

Exatamente esse mesmo questionamento poderia ser refeito, dessa vez não em termos de resultados financeiros, mas em termos de desenvolvimento de novas drogas. Nas palavras do Dr. Knoopers: "In the USA, will increasingly constrained context in which we operate force us to reduce our commitment to discovery and innovation - preferably core innovation - by creating a situation in which harsh economic realities must prevail over the long range needs and aspirations of our people for better health care? This is being watched very carefully by many innovative European pharmaceutical firms who can see that U.S. firms might in the future become non-competitive with firms in European countries. If this should happen - and there is a trend in that direction - we would simply have to internationalize ourselves more and more". 


\section{A questão principal: A patente.}

\section{Conceito de Monopólio}

Em economia, monopólio (do grego monos, um + polein, vender) é como se denomina uma situação de concorrência imperfeita, em que uma empresa detém o mercado de um determinado produto ou serviço, impondo preços aos que comercializam. O poder de monopólio de uma empresa depende da facilidade com que outras empresas são capazes de entrar nesse mesmo negócio. Existem várias formas de barreiras à entrada, tais como os direitos de exclusividade (no caso da indústria farmacêutica, as patentes) e as economias de escala - que são as formas mais comuns. A compreensão desse ponto é de fundamental importância para a argumentação principal desse trabalho

Quando uma empresa se aproveita de seu poder de monopólio para fixar o preço acima do custo marginal, os consumidores compram uma menor quantidade, a um preço mais elevado. Isso implica uma redução do excedente do consumidor, correspondente à diferença entre o preço que os consumidores estariam dispostos a pagar e o preço de mercado de cada unidade consumida. Parte do excedente do consumidor perdido não é capturada pelo vendedor, resultando em um peso morto para a sociedade. Portanto, mesmo que os ganhos dos produtores fossem redistribuídos aos consumidores, a sociedade continuaria sofrendo uma perda de bem-estar. Ter o poder de monopólio significa simplesmente o vendedor ter algum controle sobre o preço do produto, sem uma curva de demanda (Mankiw, 2005).

Os preços são determinados de maneira bem diferente nos mercados monopolistas e nos mercados competitivos. Um ambiente ideal para testar essa teoria é o mercado de medicamentos, porque este contém as duas estruturas de mercado. 
Quando uma empresa descobre um novo medicamento, as leis da patente the concedem um monopólio sobre a venda do medicamento em questão. Aliás, o monopólio the é concedido pela própria regulamentação que determina uma quantidade enorme de investimentos em pesquisa pré-clínicas e clínicas. É o chamado Dossiê de Registro. Muito poucas empresas têm recursos financeiros suficientes para arcar com os custos do desenvolvimento de um medicamento.

As indústrias farmacêuticas, consideradas monopolistas, cobram preços bem superiores ao custo marginal de produção do medicamento. É tentador censurar essa indústria por explorarem os pacientes/consumidores. De fato, esses monopólios obtêm altos lucros por seu poder de mercado. Mas, o lucro da empresa não é, por si só, necessariamente um problema para a sociedade. $O$ bem estar em um mercado monopolizado inclui tanto o bem estar dos consumidores quanto o dos produtores. Quando um consumidor paga um real a mais para um produtor, no caso a indústria farmacêutica, sua situação piora em um real e a do produtor melhora no mesmo montante. Mas, essa transferência dos consumidores para a indústria farmacêutica não necessariamente afeta o excedente total do mercado que é a soma dos excedentes do consumidor e do produtor. Argumenta-se que esse excedente (ou essa perda, dependendo do ponto de vista), é o que financia novos desenvolvimentos de novas drogas. Esse assunto será discutido em profundidade nos capítulos que se seguirão.

Outro assunto técnico que merece ser discutido para melhor compreensão da argumentação que se seguirá é a elasticidade de preço. A elasticidade de preço é uma medida da resposta dos consumidores a mudanças de preços (para baixo e para cima) de produtos (bens ou serviços). A elasticidade é uma medida da sensibilidade de procura de um determinado bem face às variações no seu preço. Por medida, entende-se que ela pode ser representada através de números ou coeficientes. Por resposta, entende-se que existe uma relação de estímulo-resposta envolvida. Mudanças nos preços (estímulos) provocam alterações no comportamento de compra (resposta). Dependendo do tipo de produto e do segmento de mercado afetado, a elasticidade da demanda se apresenta de forma diferente. 
Quando a quantidade procurada de um determinado bem diminui muito após um aumento pequeno do seu preço, esse fato representa uma elevada sensibilidade da procura relativamente ao seu preço, ou seja, uma elevada elasticidade - neste caso diz-se que o bem tem procura elástica em relação ao preço. Ao contrário, quando a quantidade procurada do bem diminui pouco, mesmo que o aumento do preço seja elevado, isso representa uma baixa sensibilidade da procura relativamente ao seu preço, ou seja, representa uma baixa elasticidade ou ineslaticidade - neste caso diz-se que o bem tem uma procura rígida em relação ao preço.

Matematicamente, a elasticidade da procura preço é calculada através da divisão da variação percentual na quantidade procurada pela variação percentual no preço.

$$
E_{D}=\frac{\Delta q / q}{\Delta p /} \quad \begin{aligned}
& \text { Em que: } \\
& \text { Eq representa a elasticidade da procura pre ço } \\
& \begin{array}{l}
\text { q representa a variaçä́o na quantidade procura da } \\
\text { qp representa a quantidade pro curada } \\
\text { p representa a variaça no preço }
\end{array}
\end{aligned}
$$

Dado que as variações dos preços e das quantidades são, geralmente, contrárias, devido à inclinação negativa da curva de demanda, a elasticidade apresenta, nestes casos, valores negativos.

Por este motivo, ambas as variações são transformadas em valores positivos de forma a que a elasticidade apresente também valores positivos. No caso da elasticidade da procura ser superior a um, significa que a variação percentual na quantidade procurada é superior à variação percentual do preço, o que significa que estamos perante um bem de procura elástica em relação ao preço. Se, pelo contrário, a elasticidade estiver entre zero e um, tal significa que a variação percentual na quantidade procurada é inferior à variação percentual do preço, ou seja, que estamos perante um bem de procura rígida em relação ao preço. Quando a elasticidade é um, diz-se que estamos perante um bem de elasticidade unitária. 
Geralmente, produtos que não têm substitutivos à altura apresentam menor elasticidade, enquanto que produtos com uma grande quantidade de substitutivos apresentam maior elasticidade. Certos produtos têm sua demanda praticamente inalterada em função de variações de preço, ou seja, são totalmente inelásticos, como é o caso cigarros e medicamentos de uso contínuo.

Os medicamentos podem ser considerados inelásticos, uma vez que:

- o profissional que o prescreve o faz customizado aos pacientes, de acordo com sua doença, idade, patologias concomitantes, de forma que é a substituição desta é mais improvável.

- o consumidor final (paciente) não detém de conhecimento suficiente para comprar o medicamento que quer, dependendo exclusivamente do que the foi prescrito.

O objetivo desse breve resumo técnico sobre alguns conceitos de microeconomia é preparar o terreno para a discussão que se seguirá sobre a importância da lei de patentes na construção dos critérios de cientificidade na medicina contemporânea e para as relações destes com os sistemas de barreira a um comércio de preços livres na área terapêutica. 


\section{A Lei de patentes - A quarta crise.}

O Sr. J. T Connors, Secretário do Comércio do Presidente Lindon Johnson do período de 1965 a 1967 declarou em 1963: "Today I wish to concentrate on one aspect that seems to me to have important implications for future progress in the health field... It is a subject toward which many members of this conference may not have developed an instinctive feeling of good will. I am raising this issue because of my strong conviction that it must be resolved constructively if chemotherapy and biological are to continue to advance at anything like the date in recent years. I refer to patent" (Clymer, 1970). Um pequeno detalhe biográfico para iniciar a descrição do assunto: "John T. Connors, antes de sua função pública, havia sido Presidente da Merck \& Co. por muitos anos.

Uma análise da preocupação do Sr. J. T Connors pode esclarecer alguns aspectos importantes. Apesar de vários autores referidos previamente apontarem para a deficiência de uma melhor interação entre a academia científica, governo e indústria farmacêutica, na verdade, essa questão poderia também ser vista sob um outro ponto de vista, este de natureza histórica. Muitos dos extraordinários desenvolvimentos ocorridos na ciência farmacêutica e na terapêutica médica a partir da década de trinta ocorreram em função de uma integração colaborativa entre as indústrias farmacêuticas e as escolas de medicina. Essa interação ocorria através de financiamentos públicos relativamente altos, particularmente endereçados para o National Institute of Health (NIH), que, por sua vez, distribuía mais de oitenta por cento desse valor para os laboratórios de ciências básicas das universidades americanas, e menos de três por cento diretamente para as indústrias farmacêuticas.

Durante todo o período que se está estudando nesse trabalho, vários setores da sociedade americana, e alguns exemplos serão citados posteriormente, alegaram que os frutos positivos desses financiamentos governamentais deveriam por direito pertencer ao domínio público e não aos interesses privados de qualquer empresa particular. $\mathrm{O} \mathrm{NIH}$, em particular, começou a exigir que a indústria farmacêutica abrisse mão de toda reivindicação de 
propriedade intelectual sobre eventuais invenções que resultassem de esforços colaborativos, quando estes tivessem algum tipo de participação pública. $O$ contra-ponto desse argumento era que, devido a todas as exigências legais para se registrar um novo produto farmacêutico, os valores investidos pelo Poder Público, representavam apenas uma parcela mínima, quase insignificante, em relação ao investimento total. Essa discussão levantada pelo Sr. Connor remonta ao início da década de sessenta, quando os custos de desenvolvimento de uma nova droga e as exigências legais para registro e comercialização dessa droga eram relativamente baixos em relação aos que viriam a ser nas décadas seguintes. Além disso, essa discussão explica, de alguma forma, porque o financiamento privado de instituições científicas minguou, a ponto de vários professores universitários, uma década depois, estarem reivindicando dramaticamente uma maior interação entre a indústria e a comunidade científica a fim de manter seus laboratórios funcionando. $O$ fato é que, em decorrência dessa atitude do $\mathrm{NIH}$, descrita acima, as indústrias farmacêuticas decidiram realizar todos os investimentos em suas próprias instalações e com seus próprios recursos. Veremos adiante que não valia a pena correr o risco de perder os direitos de proteção sobre um investimento em inovação.

Em um debate ocorrido em 1971, o economista Sr. Howard Forman (Forman, 1970), citando os argumentos descritos no parágrafo anterior, e iniciando uma discussão sobre a retórica daquela época a respeito da lei de patentes aplicada à indústria farmacêutica, questiona, à luz da razão, se o direito de propriedade intelectual poderia ser questionado, quando cem por cento de um eventual desenvolvimento de um produto farmacêutico fosse proveniente de uma indústria privada. Nesse ponto fica claro que, naquela época, nos anos sessenta e setenta, além das crises já descritas (econômica, científica e institucional), algo mais estava acontecendo na sociedade americana. No vácuo das reformas que vinham ocorrendo desde o final da guerra, um profundo questionamento sobre um dos fundamentos mais sólidos do sistema econômico, a lei de patentes, estava em curso e operação. 
O Sr. Forman, para situar melhor a questão, reporta o início histórico dessa discussão sobre a legitimidade social da lei de patentes nas audiências promovidas pelo Senador Estes Keffauver, a partir de 1959, no Subcomitê de Antitruste e Monopólio, que investigou, entre outros aspectos, os preços praticados pelas indústrias farmacêuticas americanas. Outra referência da origem dessa discussão no cenário legislativo foi a igualmente muito famosa audiência promovida pelo Senador democrata Gaylord Nelson sobre as práticas monopolistas na economia americana, que ocorreu na década de sessenta. Em ambas as investigações, foi explicitamente proposto que a lei norte-americana de patente fosse revista no sentido de possibilitar o licenciamento compulsório das patentes de droga, e, especialmente, a introdução do conceito de que toda patente de droga estaria automaticamente garantida a qualquer um que a solicitasse após apenas três anos depois de concedida a seu proprietário original. Esta proposta seria uma ruptura radical com o sistema vigente na época, que concedia (e ainda concede) de dezessete a vinte anos de proteção para novas invenções (eventualmente esse prazo pode, em algumas condições ser estendido). Curiosamente, essa proposta de modificação da lei de patentes era específica e se aplicava apenas à industria farmacêutica. Segundo o Sr. Forman, se essa proposta fosse colocada em prática ela certamente afetaria negativamente, e de forma considerável, toda a capacidade inventiva e de produzir inovações da sociedade americana no que tange a descoberta de novas drogas, e que, em conseqüência, o interesse público seria seriamente comprometido.

Dessa forma, a questão era: há uma crise de novas descobertas, as exigências regulatórias se tornam cada vez mais complexas, e, além disso, a lei de patentes que, teoricamente, garantiria o financiamento do risco envolvido no processo de descoberta de drogas inovadoras, estava sendo severamente questionado. Como, então, continuar descobrindo novas soluções para os principais problemas relacionados à saúde da população? Se a lei de patentes sofresse alguma modificação no sentido de reduzir os direitos do proprietário, por que motivo este último investiria em um novo desenvolvimento? Por que correr risco, financiando um processo inovativo em uma área que, como vimos, não segue o modelo tradicional da abordagem edisoniana (o que significa dizer 
que não se trata de um processo que se caracteriza pela combinação racional de tecnologias disponíveis com o objetivo de se conceber uma idéia mais ampla e poderosa e que acaba por conduzir ao desenvolvimento de um novo produto, na descoberta de novas moléculas o processo é fundamentalmente caracterizado pelo sistema de tentativa e erro) ?

Apesar desses argumentos parecerem bastante sólidos, havia, obviamente, aqueles que procuravam demonstrar exatamente o oposto, ou seja, que a proteção patentária era apenas uma barreira à competição, e que outros países que não tinham uma lei de patentes vigente em seus territórios tinham uma produtividade, em termos de novas descobertas na área farmacêutica, ainda maiores do que a norte-americana. A leitura do texto abaixo, apresentado em uma das audiências promovidas pelo Senador Keffauver demonstra isso: "The commitee concluded that most of the supremacy of U.S. firms was based upon the tetracycline family as well as chloramphenicol, in other categories the U.S. discoveries are easily surpassed by discoveries in those foreign countries which do not award patents on pharmaceuticals".

Junto com esse discurso foi apresentada uma tabela que demonstrava as descobertas farmacêuticas por cada país individualmente ao longo dos anos. Segundo o Sr. Forman, essa argumentação havia sido completamente destruída através da análise um pouco mais cuidadosa dos próprios dados apresentados, particularmente pelo fato de que países como a Alemanha e a Suíça, que no corpo da argumentação não tinham lei de patentes vigente, na realidade tinham uma lei e esta era bastante restritiva.

Havia, portanto, duas formas de se argumentar no sentido de propor mudanças na lei de patentes. A primeira referia-se ao financiamento público através do $\mathrm{NIH}$, que deveria garantir ao domínio público todo desenvolvimento que tivesse alguma participação das verbas provenientes de impostos arrecadados pelo governo, e, em segundo lugar, uma avaliação comparativa com outros países, que visava demonstrar que os Estados que não tinham leis de patentes vigentes tinham um desempenho em novas descobertas farmacêuticas maiores do que os Estados Unidos. 
Mas, os argumentos a favor das mudanças não se restringiam a esses dois pontos. Havia ainda mais três outros flancos de ataque: 1) as margens de lucro da indústria farmacêutica, 2) a garantia da utilização e livre promoção das marcas dos produtos, 3 ) as modificações marginais de moléculas já conhecidas e que poderiam ganhar o status de inovação com conseqüente proteção patentária.

\section{A questão das margens de lucro}

A questão das margens de lucro refere-se a um julgamento, quase que de natureza moral, sobre o que deveria ser considerado um lucro justo. A premissa era de que os lucros apresentados nos balanços das empresas farmacêuticas eram excessivos e que, pela natureza mesma dos produtos envolvidos, ou seja, remédios, e as características do mercado consumidor, ou seja, seres humanos doentes, haveria que se pensar novos critérios para definir um lucro justo que não apenas os econômicos. O que deveria ser considerado como razoável para uma empresa farmacêutica lucrar? Após anos de uma política neoliberal em curso no mundo todo, e do processo de globalização permeando nossas mentes a cada dia, essa discussão parece até infantil, contudo, como vimos, nos anos sessenta e setenta esse tipo de discussão, e sobretudo nesse formato, enquadrava-se perfeitamente bem dentro da racionalidade política e econômica da época.

A contraposição a esse tipo de argumentação era avassaladora, tanto do ponto de vista qualitativo quanto quantitativo. Os argumentos iam desde os princípios normativos do utilitarismo do filósofo J.S. Mill, que já discutimos, até estatísticas provando que a relação entre os lucros versus os ativos do setor farmacêutico estava abaixo dos outros segmentos, como o de computação e até o automobilístico (Clymer, 1970). Além disso, questionava-se também, naquela época, ainda muito timidamente, numa perspectiva farmacoenômica, a relação entre custo e efetividade. Um exemplo para ilustrar melhor o argumento contra uma análise das margens de lucro numa perspectiva absoluta: Qual era 
o custo e as conseqüências de uma mastoidite antes da era dos antibióticos em relação àquele momento? $\mathrm{O}$ que era o preço de um antibiótico quando pensado nessa perspectiva?

Essa discussão, aparentemente fora de contexto, visava questionar o monopólio conferido pela lei de patentes, que garantia ao produtor de medicamentos a liberdade de praticar um preço artificial e mais alto do que aquele que seria praticado em um mercado unicamente direcionado pelas leis de mercado e pela prática da concorrência. Sob esse ponto de vista, a causa imediata dos altos preços dos medicamentos era a falta de concorrência, resultante da proteção conferida pela lei de patentes.

Como contra-ponto a essa argumentação, vale citar um trecho escrito pelo economista inglês J.D. Cooper a esse respeito: "patents are the essential means by which a firm gains the funds for its future research, rather than a reward for its past efforts. It enables continuity so essential to research" (Cooper, 1970). Vale a pena ler outro trecho do mesmo autor, dessa vez sob uma ótica mais filosófica: " The normal aim of enterprise in a capitalist society is to maximize profits. This is usually only condemned when the profits surplus accrues from restrictive practices rather than from ingenuity and efficiency. In some cases we remove an industry from the private-enterprise camp, not necessarily because it is exploiting the nation by monopolistics practices, but because the State's well-being is not maximized by each individual attempting to maximize his own self-interests. We rationalize because there is division between private gain and loss, public gain and loss. It is not in these grounds that the pharmaceutical industry has been indicted, however. It has been charged firstly with profiteering out of human misery and sickness, and secondly with making excessive profits. To these charges, the industry has replied by citing its contribution to mankind's well-being through its innovational advances and by asserting that it has earned its profits by reason of these discoveries and by the fulfillment of a success of new needs" (Cooper, 1971 a).

Realmente, em uma sociedade fundada sob os princípios do utilitarismo, fica no ar uma pergunta de difícil resposta: o que é um lucro excessivo? 
A questão do uso de marcas em produtos farmacêuticos

Outro ponto que era freqüentemente abordado com o objetivo de modificar a lei de patentes era o uso, por parte da indústria farmacêutica, de marcas e direitos autorais. Na já referida audiência capitaneada pelo Senador Nelson sobre práticas monopolísticas na economia americana, discutiu-se que as leis que amparavam a possibilidade de prescrição de um medicamento pelo seu nome de marca, aliado obviamente à proteção de mercado instituída pela lei de patentes, marcavam indelevelmente as cartas do mercado farmacêutico a favor dos produtores de medicamentos em detrimento do consumidor, isto é, dos pacientes (Mund, 1970).

Essa discussão se misturava com a, também nascente na época, discussão sobre o mercado de produtos farmacêuticos genéricos. Como já dito, esse assunto mereceria uma dissertação à parte por sua importância e sua rica documentação, entretanto, nesse contexto, o que de fato nos interessa é apontar para a intercessão entre um eventual fim da proteção patentária para produtos farmacêuticos (ou outro sistema qualquer como, por exemplo, licenciamento compulsório), e a permissão de prescrição de um medicamento com nome de marca. Essa intercessão, segundo as conclusões da Audiência, era um dos fatores responsáveis pelos altos preços praticados pela indústria de medicamentos, preços típicos de um mercado monopolizado. A relação entre esses fatores era o que de fato era o alvo de críticas, e, era o que deveria ser institucionalmente modificado em favor de uma sociedade mais justa e igualitária.

A resposta da indústria, e dos defensores do seu ponto de vista, era muito simples: dizia que não havia nenhuma diferença entre a proteção que as marcas de medicamentos tinham em relação a outras marcas de outros segmentos. Ao contrário, as enormes exigências regulatórias aliadas às restrições de divulgação próprias ao mercado de medicamentos, faziam com que as indústrias farmacêuticas ficassem em franca desvantagem competitiva em termos de crescimento econômico. Portanto, qualquer tentativa de restrição do uso de marcas próprias para medicamentos deveria ser encarada como 
uma profunda restrição da liberdade do agente econômico, fundamento primeiro da sociedade americana. Além disso, a marca tinha o lado positivo de identificar o produto com seu processo de produção e qualidade, e isso era um bem que deveria ser preservado, e não destruído.

A questão das modificações moleculares como inovações

Por último, como desfecho da lista de argumentos a favor da mudança na lei de patentes, deve-se citar a questão da modificação de moléculas já existente como critério de inovação, e, portanto, como garantindo direitos de proteção patentária. Os termos utilizados em inglês para essa prática são: "molecular manipulation" e "product diferentiation". Este ponto é extremamente importante para a defesa dessa tese, portanto será analisado em maior profundidade do que os dois tópicos anteriores.

Esse é um assunto bastante polêmico, freqüentemente citado na literatura da época sob os mais diferentes pontos de vista. Os cientistas, os empresários, os legisladores, os advogados e, finalmente, os economistas discutiam profundamente esse assunto.

É interessante ver como um economista analisa essa questão. A referência é novamente a audiência promovida pelo Senador Nelson no final da década de sessenta. Em uma conversa travada entre o Senador e um economista chamado a depor, o Dr. Schifran, fez-se a proposição de que a maioria dos investimentos em pesquisa realizados pela indústria farmacêutica, apesar de vultuosos, era um verdadeiro desperdício, uma vez que tais pesquisas visavam fazer apenas pequenas modificações em moléculas já existentes, e que essas modificações normalmente não tinham praticamente nenhuma conseqüência terapêutica benéfica. $O$ processo, na verdade, visava apenas qualificar a modificação molecular como uma inovação para, valendo-se desse artifício, garantir-Ihe uma proteção pela lei de patentes. 
A partir dessa posição, o Senador Nelson elabora a seguinte pergunta: "Se um novo composto químico for descoberto e patenteado por uma empresa de pequeno porte, uma empresa de grande porte poderia, analisar essa molécula, fazer algum tipo de modificação em sua estrutura e patentear essa nova molécula?" (Mund, 1970). A resposta é afirmativa! A patente é concedida às custas da divulgação pública da estrutura da molécula, e esta pode sofrer um processo de modificação e acabar sendo caracterizada como uma nova molécula.

A idéia por detrás dessa pergunta era obviamente subverter a noção corrente de que a proteção conferida por uma patente, e os conseqüentes preços mais altos praticados, deveriam, ambos, servir para prover o produtor de recursos que possibilitariam no futuro novas descobertas. Além disso, coloca em dúvida outra concepção também corrente, de que a competição na indústria farmacêutica se dava sempre de forma muito intensa, exatamente na corrida pela busca de novas moléculas inovadoras. Esse exemplo teórico, e um pouco teatralizado, procura desvelar informações sobre um processo que poucos de fato conheciam em todos os seus detalhes: o que de fato se protege como uma inovação na área farmacêutica através do instituto da patente? O que exatamente a sociedade está comprando quando garante a um produtor os direitos de comercialização monopolístico de uma nova molécula com fins terapêuticos?

Como nos outros pontos, vamos aqui também, tentar analisar os contraargumentos sob a perspectiva, não do desenvolvimento científico, mas da importância da manutenção de um processo monopolístico com o objetivo de financiar esse desenvolvimento.

O primeiro argumento contrário refere-se ao rigor, ou aos critérios para se garantir uma patente farmacêutica. Segundo Howard Forman (Forman, 1970), o preenchimento dos critérios tradicionais de: novidade, utilidade e não obviedade, não é tão facilmente demonstrável como faz parecer ser a história contada pelo Senador Nelson em sua audiência pública, e que descrevemos nos parágrafos anteriores. Além disso, esse processo de manipulação 
molecular, que na referida audiência parece ser uma coisa muito banal e simples, na verdade envolve bastante conhecimento científico, experiência prévia e, sobretudo, consideráveis investimentos financeiros para ser bem sucedido. Uma outra consideração é de que mudanças aparentemente mínimas podem trazer consideráveis benefícios terapêuticos, sejam estes em condições médicas que antes não tinham nenhuma alternativa terapêutica, sejam em outras condições onde há opções, porém estas poderiam ser melhoradas, tanto do ponto de vista de eficácia quanto de segurança.

O segundo argumento, este muito poderoso, é de que o Escritório de Patentes (órgão que julga e delibera sobre um direito de patente nos EUA), quando se trata de medicamento, exige muito mais provas de real inovação do que em outras invenções. E que provas adicionais são essas? O Escritório de Patentes exige provas na forma de demonstração clínica de que um novo produto farmacêutico é sempre: seguro, efetivo e confiável.

Isso significa que, independentemente da origem tecnológica de uma nova molécula para uso terapêutico em humanos, seja uma molécula totalmente nova, seja uma molécula resultante de um processo de manipulação molecular, seja uma substância de síntese química, seja um produto resultante de um processo biotecnológico, seja um antibiótico ou um antihipertensivo. Sempre, em todos os casos, o instituto da patente será concedido se se provar que o resultado da descoberta é seguro, efetivo e confiável através de demonstração clínica. O interessante desse argumento é que ele não corresponde totalmente à realidade, uma vez que, quando uma patente é concedida (ou negada), em geral dois a três anos após a aplicação da mesma ao Escritório de Patente, normalmente nem uma única dose terá sido dada a nenhum ser humano. Toda e qualquer argumentação a favor de uma real novidade em relação ao que já houver disponível no mercado é, no momento em que uma resposta a essa solicitação é proferida, baseada apenas em suposições e ilações ainda não confirmadas empiricamente no ambiente clínico. Não há como imaginar que o Sr. Forman não sabia disso ao defender sua posição. 
Apesar disso, é importante ficar claro que o fato de se ter o direito de patente sob uma invenção farmacêutica, não significa de forma alguma que se tenha o direito de comercialização do produto final, resultante dessa invenção. Há um longo, arriscado e extremamente caro trajeto entre a invenção e o produto comercial. Esse trajeto é pavimentado com uma serie de evidências experimentais, em animais e humanos, cujo objetivo é exatamente produzir uma racionalidade de cunho científico que garanta que a droga nova proposta seja segura, efetiva e confiável. A tarefa da agência reguladora é exatamente julgar essas evidências, e ceder ou negar o direito de comercialização e marketing do novo produto.

Portanto, há duas instâncias, que, pelo menos teoricamente, não necessariamente se relacionam entre si: o direito de patente e o direito de comercialização. Agora voltemos ao problema da manipulação molecular e vamos tentar analisá-lo um pouco mais detalhadamente à luz dos vários argumentos que já foram discutidos nas seções anteriores.

Ao se modificar uma molécula já existente, pode-se, em linhas gerais, obter-se cinco resultados distintos: 1) uma nova substância sem nenhuma atividade biológica, 2) uma nova substância mais tóxica do que a anterior, 3) uma nova substância mais eficaz do que a anterior, 4) uma nova substância que mostra uma nova ação terapêutica distinta da que já era conhecida, e, por último, 5) uma nova molécula em tudo igual a anterior do ponto de vista de sua ação terapêutica.

As quatro primeiras condições não são objeto de qualquer tipo de polêmica. $O$ julgamento de se representam ou não uma inovação é bastante óbvio, mas é em torno da quinta situação que a polêmica sobre a patente era mais discutida. Cumpre recordar que o desencadeante primeiro dessa polêmica não era absolutamente de natureza científica em sua estruturação discursiva. O que se discutia era o preço dos medicamentos.

Outro ponto que se deve recordar é o de que os anos sessenta e setenta caracterizavam-se por um período de crise de novas descobertas. Esta crise 
tinha várias facetas que iam desde uma baixa interação entre centros universitários de pesquisa básica em farmacologia e a indústria farmacêutica financiadora de novas descobertas, até a saturação do modelo de busca de inovações através do rastreamento de receptores biológicos conhecidos para as doenças de maior prevalência. Esse assunto já foi suficientemente discutido nas seções precedentes. Importa agora tentar juntar todos os fatos descritos de uma forma que tenham um conteúdo explicativo racional.

Lembremo-nos também que, além da crise científica, havia também uma crise econômica grave, e que os fundamentos das políticas econômicas dos principais países desenvolvidos do mundo estavam sendo severamente questionados. Era o fim do keynesianismo instituído após a guerra.

No rastro dessa crise econômica uma nova arte de governar emergiu, e esta, tinha como um dos seus principais fundamentos a construção de um edifício regulatório que deveria ser custo efetivo. Toda e qualquer participação do Estado que não agregasse valor ao sistema de concorrência entre os agentes econômicos deveria ser criteriosamente reavaliado, e se, eventualmente, não se conseguisse provar sua utilidade para o sistema econômico como um todo, deveria ser eliminado.

Por último, retomemos a questão que denominamos de crise institucional, mas agora na perspectiva em que estamos trabalhando, ou seja, na questão das patentes. Não era só a estrutura do FDA que estava sendo questionada, não era só a falta de critérios objetivos para se atender às exigências da EKH que se buscava solucionar. No meio de toda essa discussão havia também um forte movimento para se modificar drasticamente o sistema de proteção de patentes para os medicamentos nos EUA. Chamo esse fato de quarta crise.

A proposta de mudança mais radical era simplesmente extinguir o instituto da patente para novas drogas. A outra proposta, essa mais branda, e que as referências analisadas indicam ter mais defensores, era permitir a exclusividade apenas por um tempo que garantisse o retorno do investimento 
na pesquisa, que, na década de setenta, era calculado em três anos, aplicando, após esse período, um processo de licenciamento compulsório.

Essa era uma discussão bastante calorosa e intensa, que se iniciou no final da década de cinqüenta, quando se iniciaram as audiências do Senador Kefauver, se estendeu por vários anos, e sobre a qual, na verdade, no início da década de setenta, estava-se ainda muito longe de se ter alguma posição consensual. Como vimos na discussão precedente, havia argumentos fortes e racionais em mais de uma posição. Essa discussão poderia ser consideravelmente aprofundada, sobretudo com argumentos de natureza econômica, mas a conclusão seria de que não havia conclusão sobre o assunto. Posições antagônicas se defrontavam em busca dos melhores argumentos. Entretanto, a título de defesa de um dos pontos fundamentais desse trabalho, julgo fundamental apontar e provar o fato histórico de que, em meados da década de setenta, em meio a todas as crises já descritas e em um momento em que os princípios da regulamentação econômica sofriam um processo de revisão radical, o instituto da patente no segmento farmacêutico era o cerne do problema. Era em torno da defesa da manutenção desse instituto, ou na posição contrária, na sua revogação total ou parcial, que os argumentos opostos se articulavam. Além disso, por uma circunstância histórica particular, nesse período, o lado que buscava a flexibilização das regras vigentes tinha muitos aliados, e consideráveis chances de obter sucesso. Para demonstrar esse ponto, vale a transcrição do texto de um Professor de Economia da Universidade de Michigan, o Sr. Frederick M. Schereber: "From the ferment that exist in this area, a practical man must recognize that something is going to happen with respect to drug patent rights. The atmosphere on Capitol Hill is such that it is very difficult to avoid some kind of compulsory licensing" (Howard, 1970).

Ver os fatos numa perspectiva retrospectiva é muito interessante, uma vez que, de concreto nenhuma mudança ocorreu na lei de patentes norte-americana no sentido de torná-la menos rigorosa. Ao contrário, se algo aconteceu, foi no sentido contrário de permitir, com maior benevolência, prorrogações de direitos patentários por demora do processo de desenvolvimento, quando esse fato, 
bastante comum, ocorre em função de exigências regulatórias. Entretanto da década de setenta até os nossos dias as exigências técnicas para se provar a eficácia de uma nova droga, se tornaram extraordinariamente e incomparavelmente mais complexas. Será que há uma relação entre esses dois fatos? Será que há uma relação entre esses dois fatos e uma busca pragmática de solução institucional para as várias crises que descrevemos?

Após essa breve rememoração e alinhamento do cenário histórico no qual estamos nos debruçando há várias páginas, e das várias crises dos anos sessenta e setenta, o que nos ajudou a formular as duas perguntas descritas no final do parágrafo anterior, vamos voltar à problemática da legalidade, efetividade, ou até mesmo justiça do exercício do direito conferido pela patente sob uma molécula que, na verdade, não tem nenhuma inovação real em relação à outra que já está sendo comercializada.

Retomemos o argumento apresentado pelo economista Howard Forman, e descrito nas páginas anteriores, de que, para obtenção de uma patente em medicamentos, havia que preencher três critérios: novidade, utilidade, não obviedade. Na descrição anterior havia dito que, isso era apenas parcialmente verdadeiro, porque, como aponta diretamente o economista Sr. Leonard G. Schifran, PhD, Chefe do Departamento de Economia do College of William and Mary e personagem bastante citada em toda a discussão: "You will notice that of all the standards Dr. Forman gave to patentability, therapeutic superiority is not included" (Forman, 1970). Fica a pergunta: o que é exatamente uma novidade no caso de uma manipulação molecular que garante a essa técnica o direito de uma proteção pela lei de patentes?

A resposta a essa interrogação é uma sutileza que escapa em muito os objetivos desse trabalho, entretanto, uma breve explicação faz-se necessária. Ao se promover uma modificação numa molécula pode-se solicitar o status de novidade com argumentos científicos que têm muito pouco a ver com a clínica. Por exemplo, uma determinada ligação apenas parcial com um certo receptor celular, em contraposição a outra molécula, já existente, e que promove uma ligação total. Pode-se até argumentar com o fato de que essa hipotética ligação 
ser diferente do ponto de vista apenas qualitativo da molécula de referência. Há uma infinidade de exemplos a esse respeito, e é claro que, na vida real, provar uma novidade para o Escritório de Patentes norte-americano não é um processo tão simples como essas palavras podem parecer demonstrar.

A questão que quero novamente destacar, não é a respeito dos critérios técnicos de julgamento de uma solicitação de patente, o que quero destacar, é que a patente pode ser concedida (e normalmente é) independentemente de se comprovar real novidade de sua aplicação. Mas importa não esquecer que, após o desenvolvimento e o registro dessa molécula, ao se ter o direito de exclusividade, tem-se também o controle sobre o preço a ser cobrado. E aqui fechamos o ciclo, quero dizer, a posse do direito de patente dá ao produtor de um medicamento o controle sobre a oferta e o consumo do seu produto. Num mercado monopolizado, como é o mercado farmacêutico, caracterizado por uma curva de demanda inelástica, ter um produto de prescrição obrigatória, cujo preço é estipulado pelo produtor, e tendo a capacidade de convencer os médicos a prescrevê-lo, aliado a uma capacidade de distribuí-lo adequadamente nos canais de comercialização, tudo isso junto, garante retorno financeiro certo, e, normalmente com altas margens de lucro sob o capital investido. É essa a essência do negócio farmacêutico. Agora o que isso tem a ver com os sacrossantos e supostamente neutros critérios de cientificidade que garantem a eficácia e a segurança de uma nova droga?

\section{Considerações finais}

Estamos nos aproximando do final de nossa argumentação. Esse longo caminho na realidade poderia ser resumido em alguns fatos relativamente simples. Abaixo vou enumerá-los didaticamente:

A medicina contemporânea adota critérios de racionalidade científica para efetividade terapêutica bastante claros e objetivos. 
Esses critérios baseiam-se fundamentalmente em dados de natureza empírica submetidos à prova de veracidade através de um processo de ensaios clínicos comparativos.

O nascimento desse método remonta aos anos sessenta.

Nos anos sessenta grandes mudanças germinavam no ventre das sociedades ocidentais desenvolvidas, e estas tinham uma relação direta com uma grave crise econômica resultante do modelo implementado depois da Segunda Guerra Mundial.

A descoberta de novas drogas, após um período muito profícuo, havia chegado a um ponto de estagnação, a partir do qual não se vislumbravam grandes perspectivas em termos de descobertas de verdadeiras inovações.

Uma verdadeira revolução institucional estava em pleno curso, e esta se caracterizava pelo embate direto entre as forças que defendiam uma maior regulamentação dos processos produtivos por parte do Estado, e seus oponentes, que julgavam, baseados no Princípio de Utilidade, que a regulamentação deveria ser apenas aquela que assegurasse 0 perfeito equilíbrio entre os custos e os benefícios.

Essa última discussão permeou fortemente o setor da saúde, e especificamente a estrutura e os critérios de decisão do FDA.

Finalmente, no epicentro dessa revolução institucional, vibrava um questionamento sobre dois fundamentos estatutários do sistema de livre iniciativa, a saber, a otimização do lucro de uma operação capitalista e a proteção de mercado assegurada pela comprovação de um esforço de natureza inventiva, a proteção patentária.

Essa proteção conferida pela lei de patentes é o que chamaria de: A primeira barreira. Outras três barreiras serão descritas no capítulo seguinte. 
Será possível juntar todas essas coisas? Antes de prosseguir gostaria de rememorar ou apelar ao meu ponto inicial da relatividade das verdades históricas. Essa é apenas uma história, dentre várias possíveis, e, talvez muito melhores. Essa é apenas uma perspectiva, extraída de textos muito pouco freqüentados, e escritos por autores quase desconhecidos. A extração dos argumentos do corpo desses textos foi uma tarefa bastante difícil, e, cada passo, sempre seguido por uma autocrítica desconfiada. Vou agora avançar rumo ao entrecruzamento de todos esses discursos. 


\section{Barreiras}

\section{As três primeiras barreiras}

Antes de prosseguir na descrição do que estou chamando de barreiras, vale uma melhor definição do termo. Entendo por barreira uma situação, não necessariamente construída ou previamente idealizada por um agente específico, podendo se constituir como um processo consensual entre vários agentes, mas que tem como resultante final o impedimento de um determinado fluxo de crítica, que, caso a referida barreira não estivesse presente, poderia ocorrer. As barreiras que vou descrever funcionam como um anteparo, nem sempre perceptíveis aos sentidos, ou mesmo à razão, que impedem um verdadeiro pensamento sobre a questão da aplicação das regras de cientificidade aos problemas de natureza clínica. São também, e não por pura coincidência, uma forma de manter o mercado farmacêutico com seu molde caracteristicamente monopolístico.

Considero que a primeira barreira a um livre comércio na área de medicamentos, e, talvez, de alguns de seus possíveis desdobramentos, como o desenvolvimento tecnológico de um país e até justiça social no acesso a um tratamento médico, é, a própria lei de patentes. Na seqüência dessa discussão sobre a utilidade da proteção conferida pela lei de patentes, com o objetivo de estimular a inovação, em contraponto ao custo para a sociedade, que seria o preço mais alto cobrado pelas drogas protegidas, vale a pena analisar os argumentos de mais um economista. Refiro-me à Sra. Rosalind Schulman, PhD, Professora do "College of Business Administration do Drexel Institute of Technology".

A análise realizada pela Profa. Schulman (Forman, 1970) é fascinante por dois motivos. Primeiramente ela procura isolar todo componente emocional ou ideológico da discussão através de uma análise microeconômica rigorosa. Para implementar esse método, ela busca dados reais sobre empresas, produtos, 
investimentos em inovação, preços, evolução destes em série históricas dilatadas, etc.

Sua primeira conclusão é de que havia muito pouco dado disponível. $O$ segundo aspecto que chama a atenção no discurso dessa economista é o quanto a utilização de uma argumentação exclusivamente técnica em um assunto tão complicado e que envolve múltiplos fatores e interesses, pode ser tão convincente e, ao mesmo tempo, tão superficial, e até ingênuo. Como a eliminação de diversos fatores de difícil ponderação e a utilização de uma racionalidade predominantemente matemática em assuntos com grande interface social pode ser um método extremamente poderoso de produzir verdades. Finalmente, como esse método pode ser manipulado desde seus fundamentos até suas conclusões, seja por ausência de crítica, ou até mesmo por má fé (antes de prosseguir há que se dizer que definitivamente não há nenhuma indicação de má fé no discurso proferido pela Profa. Schulman. Sua análise é rigorosamente técnica). Entretanto, qualquer semelhança com a minha visão sobre o método científico conforme aplicado hoje em dia na medicina clínica não é uma mera coincidência. Definitivamente defendo a posição de que o excesso de matematização dos métodos empregados pela Epidemiologia Clínica nos problemas da prática clínica,devem ser vistos como uma forma de tentar adequar a solução às dificuldades inerentes ao problema, que muitas vezes não se beneficiam dos poderes do método.

A primeira conclusão a que ela chega, após analisar a curva evolutiva dos preços de medicamentos nos EUA nos últimos anos, foi de que esses valores mostram uma tendência a decrescer. Mesmo com o lançamento no mercado de muitos medicamentos que poderiam ser considerados como manipulações de moléculas, e não verdadeiras inovações, a tendência geral dos preços foi de cair à medida que aumentava a oferta, ou seja, que mais produtos estavam disponíveis. Não há nenhum comentário sobre o quanto é essa queda sobre a inflação no período e, sobretudo, sobre os preços relativos à extensões de linhas, novas apresentações e novas formulações farmacêuticas, reconhecidamente práticas comuns de manutenção de margens operacionais da indústria farmacêutica. $O$ argumento de que os preços de medicamentos 
tendem a cair, independentemente de serem ou não protegidos por patente, é central no conjunto da argumentação dessa autora.

Prossegue com a argumentação clássica, já discutida em outras partes desse trabalho, de que a natureza predominantemente monopolística do mercado farmacêutico presume uma curva de demanda não elástica para descrever os comportamentos dos produtos terapêuticos. Ela não só concorda com essa proposição, como avança no sentido de dizer que a inelasticidade, que é óbvia quando se trata do consumidor final, que é o paciente (nas palavras dela: "the ultimate consumer has nothing to say about what medication he takes"), ocorre também com o médico prescritor que, em virtude da singularidade inexorável do objeto do seu trabalho, o paciente individual, sempre fica restrito a um leque relativamente pequeno de opções. Surpreende a utilização de um argumento da prática médica cotidiana de uma maneira inesperada para uma economista tão tradicional. Ela diz: "Even the physicians, who generally have the opinion to choose his patient's drugs, have practically no elasticity of demand because of an agglomeration of diseases within a particular patient which may rule out some drugs and not others. The doctor's elasticity of demand may also be limited by the presence of patient's sensitivity to one or a spectrum of drugs. Because of the paucity of competition within the therapeutic market, the physician's elasticity of demand is less than one".

Portanto, de acordo com a Profa. Schulman, realmente a característica fundamental do mercado farmacêutico é a inelasticidade da demanda característica dos monopólios. Ela conclui esse segundo argumento de sua proposição dizendo que qualquer economista concordaria com o fato de que a existência de um segmento terapêutico qualquer, composto por apenas três ou quatro drogas, de que esse número, não seria suficiente para aumentar a elasticidade da demanda nesse segmento.

Baseado nesses dois argumentos, ela conclui que a melhor forma de aumentar a elasticidade da demanda no mercado farmacêutico seria tornar todo o processo de obtenção de exclusividade de comercialização de uma molécula qualquer o mais simples possível, de uma forma que o leque de opções de 
escolha, sobretudo para o médico que prescreve, fosse o mais amplo possível. Essa estratégia, segundo ela, incrementaria enormemente a competição pelos mercados terapêuticos, e isso, fatalmente teria como conseqüência uma redução no preço geral dos medicamentos. Seu objetivo com essa estratégia seria atingir uma situação de aumento progressivo da elasticidade da curva de demanda. O pressuposto teórico seria de que, no mercado terapêutico, somente uma situação caracterizada por uma elasticidade infinita na curva de demanda, poderia gerar uma condição de lucro econômico zero ao longo do tempo. Se essa condição não fosse alcançada, sempre haveria perda para o consumidor. A argumentação se completa com o comentário de que a abolição da lei de patentes, ou a instituição de um licenciamento compulsório, teria como conseqüência a redução da competição, sobretudo na área de pesquisa e desenvolvimento, entre as várias empresas farmacêuticas, e, conseqüentemente a manutenção de uma situação econômica de monopólio, necessariamente com perda para os consumidores. Nas palavras da economista: "Let the pharmaceutical companies compete themselves to death".

Outro interessante comentário da Profa. Schuman refere-se ao período de retorno sobre o investimento de uma nova descoberta. Segundo ela, as exigências excessivas que o FDA estava pensando em fazer, sobretudo na área de segurança de longo prazo, teriam como conseqüência necessária 0 aumento do período de proteção de mercado. A lógica aqui é a de que, se uma empresa tiver menos tempo para recuperar seus investimentos em pesquisa, no tempo em que ela puder praticar o preço, protegida pela exclusividade, esse preço terá que ser mais alto. Isso geraria o efeito oposto daquela sua recomendação de natureza econômica que descrevemos no parágrafo acima, ou seja, um tempo menor de exclusividade acabaria por restringir ainda mais a elasticidade da demanda no mercado farmacêutico. Esse fato seria particularmente verdadeiro e aplicável para as descobertas resultantes apenas de manipulações moleculares e que não incorporassem grandes vantagens terapêuticas. A recusa, ou as dificuldades impostas pela agência reguladora, de liberar para comercialização o maior número possível de moléculas, sobretudo aquelas que representam pequenos ganhos (ou alterações) em relação a moléculas já comercializadas, e sobre as quais já se conhecem 
praticamente todos os efeitos esperados, sejam de eficácia ou de segurança, tem como conseqüência a perpetuação de um sistema de monopólio no mercado de medicamentos e, conseqüentemente, um maior custo para o consumidor, e maior perda para a sociedade.

A área de especialização da Profa. Schuman era a indústria do aço. Usando exemplos de antecedentes históricos nesse segmento, ela conclui que medidas econômico-políticas que conduzissem a um aumento da oligopolização do mercado farmacêutico teriam como conseqüência um processo de aumento ainda maior do sistema de regulação, da carga total de regulamentações, e isso, segundo ela, não era do interesse nem da indústria farmacêutica nem da sociedade em geral. Penso que, somente uma pessoa que não opera diretamente na indústria farmacêutica poderia falar algo tão distante da realidade.

Portanto, temos uma segunda barreira à livre competição no mercado farmacêutico. A primeira e mais obvia é a proteção de mercado conferida pela lei de patentes. Como já vimos, uma grande quantidade de argumentos técnico-jurídicos e econômicos foram arrolados e intensamente debatidos para justificar a manutenção desse instrumento em nome principalmente da perpetuação da produtividade do desenvolvimento científico na área terapêutica. A segunda barreira é menos óbvia, sobretudo por se confundir com critérios de cientificidade e com as exigências legais, mas, na realidade sua efetividade pode ser considerada ainda maior. Vamos ver como se monta essa barreira:

A tecnologia para promover modificações moleculares, e eventualmente até desenvolver novas moléculas que preencham os critérios de inovação, sendo, portanto, patenteáveis, é relativamente simples. Entretanto, conseguir cumprir todas as exigências regulatórias de prova de eficácia e segurança de uma nova molécula, mesmo que essa pertença a uma classe terapêutica já há muito conhecida, esta é uma tarefa que exige recursos que muito poucas empresas têm. Portanto, os critérios de cientificidade para prova de eficácia e segurança que foram construídos após a assinatura da EKH, tornaram-se, eles mesmos, 
uma poderosa barreira à livre competição na área de medicamentos, e, a garantia institucional de um forte sistema de manutenção de um monopólio.

E afinal, quais são esses critérios de cientificidade? Em poucas palavras a resposta seria: os multimilionários planos de desenvolvimento de drogas previamente negociados com o FDA, nos quais, através de estudos comparativos divididos em várias fases, comprova-se cientificamente que uma determinada molécula é realmente segura e eficaz. Isso legitima essa molécula cientificamente, Ihe dá o sinal verde para divulgação de suas características junto aos médicos, e, finalmente o aval para comercialização em um sistema de monopólio.

Se a patente isoladamente não era mais capaz de garantir a proteção do mercado, se a lei exigia novas e mais complexas evidências para se registrar uma nova droga, e se a proficuidade do modelo tradicional de novas descobertas de medicamentos estava em vias de se esgotar, como fazer para pragmaticamente continuar a se fazer exatamente o que vinha sendo feito, com extraordinário sucesso, nos últimos cinqüenta anos? Como reforçar as barreiras apesar de todos os discursos contrários que vinham sendo utilizados? Como manter o monopólio? Como garantir para a indústria farmacêutica margens operacionais de lucro crescentes?

A resposta: com a nascente ciência médica! Com a comprovação científica de segurança e eficácia resultante de dados empíricos obtidos através de estudos comparativos. Com um novo saber médico!

Antes de desenvolver um pouco mais esse aspecto vale, a título de circunscrever melhor essa idéia descrita no parágrafo precedente, uma outra e importante barreira à competição no mercado farmacêutico. Refiro-me à circunscrição dos monopólios a algumas especialidades preferenciais. Explicando melhor: no modelo tradicional (modelo esse que vem se modificando com as mega fusões no setor que vêm ocorrendo desde meados dos anos noventa), cada empresa farmacêutica domina partes de áreas específicas ou especialidades médicas. A cardiologia, por exemplo, ela é o 
setor de investimento prioritário de umas poucas empresas. A oftalmologia é a área de monopólio de outras empresas. Na vida real, uma grande empresa farmacêutica domina um certo território composto por um número limitado de especialidades. A ocupação desses territórios é feita às custas de vários instrumentos, muitos de natureza puramente administrativo e gerencial, como por exemplo a contratação de executivos com experiência na áreas de interesse específico. Não vamos nos ocupar desse tipo de estratégia por agregar pouco ao nosso objetivo principal. Outras estratégias, contudo, merecem ser destacadas e explicadas.

Refiro-me à forma de atuação, ou dizendo de outra maneira, a alocação de investimentos que as empresas fazem em seus respectivos territórios ou monopólios. $\mathrm{Na}$ verdade pretendo mostrar que esses dois aspectos em conjunto (o novo saber médico e os vultosos investimentos nas especialidades médicas por parte das indústrias farmacêuticas) representam a terceira barreira contra a livre competição de preços no mercado terapêutico.

A maior parte do investimento da indústria farmacêutica em uma nova droga está muito longe de ser o investimento em pesquisa e desenvolvimento. Apesar de esse ser o principal e mais utilizado argumento a favor do monopólio, da defesa da proteção conferida pela patente por dezessete a vinte anos, e pela manutenção dos preços de medicamentos cada vez mais altos, a cada dólar gasto em pesquisa e desenvolvimento por uma empresa farmacêutica, outros dois ou três dólares são gastos com atividades de marketing e vendas (Dukes, 2005). Este gasto, complexo em sua estrutura, tem como principal objetivo construir e manter posições de monopólio dentro de especialidades médicas. Usando o exemplo anterior, se uma determinada empresa é forte na cardiologia, verdadeiras fortunas são gastas anualmente para manter essa posição de força. Vários instrumentos são aplicados ao mercado para lograr a manutenção de uma posição privilegiada em um setor monopolizado. Esse instrumento pode ser uma política de descontos um pouco mais agressiva ou a publicação de um estudo clínico em uma revista científica absolutamente neutra e de reputação histórica ilibada. A colocação desses dois exemplos lado a lado é proposital, e atende a dois objetivos: 1) mostrar que a redução de 
ambos ao conceito de investimento, homogeneíza-os em sua substância, e, 2) suscitar uma reflexão especial sobre o assunto.

Portanto, os gastos bilionários para a manutenção de uma posição privilegiada em uma especialidade são a terceira barreira que queremos descrever. No parágrafo anterior abordamos essa questão de uma maneira muito genérica, colocando, num mesmo plano, coisas aparentemente distintas, como, política comercial e informação científica verdadeira, e, apelei para uma reflexão especial sobre o assunto. Agora vou restringir a análise a um aspecto particular da defesa de um território (ou de uma especialidade) que é o monopólio de uma indústria farmacêutica. Vou restringir a análise à pesquisa e desenvolvimento, ou aos investimentos em novas descobertas naquela eventual especialidade onde se tem uma posição de privilégio e proteção. Espero ao final dessa descrição voltar à terceira barreira e explicá-la um pouco melhor.

O primeiro aspecto de defesa de território através de pesquisa e desenvolvimento é o ponto quase evidente da prioridade em investimentos em novas moléculas que atendam necessidades específicas daquela especialidade onde se quer proteger uma posição. Há várias formas de se fazer isso. Pode-se aumentar o número de cientistas com projetos naquela área específica, pode-se aumentar os investimentos em laboratórios externos, universitários ou não, e que tenham projetos naquela área, pode-se licenciar produtos de outras empresas menores, pode-se fazer com essa empresas um processo de co-desenvolvimento, co-marketing ou uma simples co-promoção. Pode-se comprar uma empresa, ou pode-se planejar e executar uma fusão de empresas. Todas essas estratégias têm um objetivo comum, que é o de prover o território conquistado, via o monopólio de novos produtos, de novos lançamentos, suposta ou verdadeiramente inovadores, com o objetivo, justamente de conseguir manter essa posição. Parte-se da premissa, correta na maior parte das vezes, de que a manutenção de um território é mais fácil e mais barato do que a conquista de novos territórios. 
Na defesa de um território, portanto, a primeira estratégia é a própria inovação: a ciência aplicada à descoberta de novas moléculas. A segunda estratégia é um pouco mais sutil e difícil de explicar, mas muito mais importante para a defesa dos argumentos principais desse trabalho e, portanto, será desenvolvida a seguir. Refiro-me aos resultados dos estudos clínicos e sua utilização, seja para o registro de novos produtos, seja para a defesa de conceitos terapêuticos, junto aos territórios conquistados às especialidades médicas.

As razões que fazem um médico, um especialista, prescrever um produto em detrimento de outro igualmente eficaz e seguro, e disponível no mercado, é um assunto para uma tese específica. Um dos autores citados, quando discutimos a questão da cientificidade dos dados de eficácia, o farmacologista Louis Lasagna, ao buscar um consenso sobre o marco regulatório a ser estabelecido pelo FDA a partir dos anos setenta nos EUA, levanta a seguinte e importante consideração: "I strongly believe we need more research in the sociology of prescribing and drug demand. Why do physicians prescribe one drug with enthusiasm and neglect another that seems essentially the same in terms of effects both good or bad? What underlies patient demands for drugs? There are other things that compete, sometimes successfully, with drugs, for consumer's money. I'm thinking about alcohol, cigarettes, and that opiate of the people, television sets. It is a fact that some people, giving a choice between buying a television set or booze or having their teeth fixed will prefer the non-medical items. Why? Is prescribing a scientifically justifiable act in most instances, or one that is in essence a desire to provide the patient with something that proclaims the doctor's power to modify disease?"(Lasagna, 1970).

Difícil saber exatamente se, ao dizer essas palavras, o Prof. Lasagna estava realmente se interrogando a esse respeito, ou se estava apenas construindo argumentos para defender sua tese, que, como vimos, passava pela defesa de uma maior integração entre os centros de farmacologia clínica que, na época, buscavam recursos para sobreviver, $e$ as indústrias farmacêuticas que precisavam registrar seus produtos em um novo e mais complexo ambiente regulatório. Difícil dizer por que é praticamente um senso-comum o fato de que 
o principal fator que determina a escolha de um produto farmacêutico é o poder de marketing da empresa que comercializa esse produto (Mund, 1970; Dukes, 2005).

Pode-se dizer que as três principais ações do marketing farmacêutico são: informação, educação e persuasão. Para se realizar essas ações de uma maneira bem sucedida há vários instrumentos que podem ser acionados. Não se constitui como objeto desse trabalho o aprofundamento dessa questão, mas, de uma maneira geral, pode-se dizer que a matéria prima que praticamente todos esses instrumentos processam, de formas variadas, e com diferentes níveis de profundidade, é a evidência científica comprovada. É o dado empírico considerado como verdadeiro. É a ciência!

Lembremo-nos que estamos nesse momento discutindo as barreiras de mercado que impedem uma verdadeira livre competição na área farmacêutica. Lembremo-nos que, a primeira barreira era a própria lei de patentes, que a segunda eram as evidências clínicas de eficácia e segurança que as agências regulatórias exigem para liberar o registro de um produto, e que custam enormes quantidades de recursos, e que a terceira barreira, que agora estamos discutindo, é o enorme poder de marketing das indústrias detentoras de patentes usado com o objetivo de defender seus territórios monopolizados. Três níveis de defesa, três poderosas estratégias de manutenção do monopólio. Vamos agora voltar a essa última barreira analisando um pouco mais profundamente como exatamente ela se processa.

Estou tendo o cuidado de me aproximar cautelosamente dessa questão por saber que estou tocando em um assunto extremamente delicado. Estou dizendo que a maior parte da Verdade proferida na Ciência Médica contemporânea, tem como determinante os objetivos utilitários de manutenção de uma posição monopolística por parte de poderosas (refiro-me ao poder econômico) indústrias farmacêuticas. Mais tarde vou defender a tese de que essa situação é desejada pela sociedade e principalmente pelos próprios médicos. Vou dizer também que a forma de raciocinar dos médicos modernos é o principal instrumento para que esse sistema se mantenha, e, mais 
importante, para que a medicina perca sua dimensão humana historicamente reconhecida. Vou dizer que essa forma de raciocinar, que se cunhou a partir dos anos sessenta, teve como um de seus principais patrocinadores a necessidade de se manter o instituto da lei de patentes no setor farmacêutico e que isso foi feito através da construção de um edifício metodológico próprio, que, mais tarde acabou se chamando de Epidemiologia Clínica. Dizer essas coisas pode gerar mal-entendidos. Há que ser muito cauteloso!

Partamos do fato concreto de que existem três ou quatro moléculas de uma mesma classe terapêutica, e que estas representam pequenas modificações na estrutura de uma molécula básica inicial. Vimos que esse é um fato comum no mercado terapêutico, e que, historicamente, foi objeto de muita discussão. Contemporaneamente, sabemos que esse fato é mais do que comum. Não há necessidade de se referenciar essa afirmativa, basta abrir um dicionário farmacêutico qualquer. Na realidade esse assunto em particular, representou um dos núcleos principais em torno do qual orbitou a discussão sobre o conceito de inovação no mercado terapêutico e todas as conseqüências que poderiam advir desse status, da proteção patentária até o registro com o direito legítimo de comercialização e marketing. Partamos desse fato concreto.

Consideremos também dois outros aspectos que também já foram discutidos nas páginas precedentes. $O$ primeiro é que as novas exigências regulatórias impunham às empresas um pesado fardo no sentido de comprovar para todo novo produto evidências científicas irrefutáveis de segurança e eficácia. $O$ segundo é que as empresas competem entre si dentro de territórios monopolizados. O paradoxo se explica na medida em que cada território ou monopólio é compartilhado por poucas empresas, onde essas não concorrem livremente, mas exercem seus direitos de proteção, todas mantendo preços altos para seus produtos, através do usufruto das barreiras de mercado que estamos discutindo. Portanto temos: moléculas praticamente iguais, exigência de prova científica de eficácia e segurança e, finalmente, competição em um mercado monopolizado. Como desatar esse nó? Será possível explicar essa confusão? 
A mesma metodologia desenvolvida para garantir o registro de novos medicamentos passou a ser utilizada também como um poderoso instrumento de marketing. Os estudos comparativos passaram a buscar freneticamente a prova de que os diferenciais moleculares eram responsáveis por importantes diferenciais de importância na clínica. O menor tempo de tratamento com um determinado antibiótico, a maior sobrevida com um determinado tipo de antihipertensivo, a maior proteção dos rins com outro, a maior redução da incidência de fratura vertebral com um determinado tipo de bifosfonato, a menor incidência de eventos tromboembólicos com determinado tipo de antiagregante plaquetário. Todas essas questões, e infinitas outras, que fazem parte do cotidiano da prática clínica, que são inquietações verdadeiras e importantes do médico praticante, ou seja, dúvidas sobre qual a melhor estratégia para tratar e acompanhar um paciente, transformaram-se em investimentos de marketing. A comunidade médica acredita realmente, e de forma quase hegemônica, que a atorvastatina é superior, do ponto de vista de eficácia e efetividade terapêutica, à sinvastatina. Outros exemplos ocupariam inúmeras páginas. Julgo-os dispensáveis! Acredito que meu argumento está claro.

Todo esse processo ocorreu de forma tão intensa e avassaladora que as linguagens científicas e de marketing passaram a se intercambiar. Os instrumentos de marketing passaram por um processo de redução e concentração em torno das verdades proferidas cientificamente. Portanto a terceira barreira ao livre mercado no setor terapêutico são os diferenciais clínicos, provados cientificamente, entre as várias drogas disponíveis no mercado. Isso garante a proteção, o preço e o monopólio. Isso faz o sistema se manter!

\section{A quarta barreira}

Considerações preliminares 
Estamos falando de barreiras impostas pelos produtores de medicamentos com o objetivo de defender suas posições monopolísticas. Suas margens de lucro. Citamos: 1) lei de patentes, 2) as exorbitantemente onerosas pesquisas para registro, 3) o controle sobre as informações científicas, sobretudo aquelas relacionadas à eficácia comparativa entre duas drogas parecidas, ou entre abordagens terapêuticas alternativas. Essas barreiras têm níveis diferentes de aplicação e até de interpretação. Colocá-las em um mesmo plano é um risco que voluntariamente estou assumindo. $\mathrm{Na}$ realidade pretendo avançar consideravelmente nessa perigosa seara ao fazer a descrição de uma quarta e última barreira, talvez a mais importante para a junção dos planos que descrevi na introdução desse trabalho. Esta ainda mais sutil e difícil de explicar do que a terceira, mas, sem a qual não conseguiria concluir minha argumentação. Refiro-me ao paradigma de cientificidade da medicina contemporânea. Como funciona o gabarito de inteligibilidade que define o discurso médico como ciência? O que é legítimo cientificamente, e o que não é? O que é a Verdade na Ciência Médica? O que, tomando-se como referência apenas a questão da produção de verdade científica em medicina, direciona os atos médicos na prática clínica?

Já em várias outras ocasiões fiz questão de deixar claro que não pretendo empreender uma discussão epistemológica tradicional. Isso em si seria objeto de uma tese que na minha opinião, dificilmente, mesmo que realizada com extremo rigor, conseguiria avançar substantivamente no sentido de produzir uma crítica verdadeiramente emanciapadora ao processo de uso predominante da racionalidade científica matemática na prática médica. A opção metodológica para atingir esse objetivo que optamos foi uma espécie de análise dos discursos que atingem diretamente, ou apenas tangenciam, a ordem metodológica da ciência médica contemporânea. Minha proposta é tentar entender essa questão através da história de como uma das questões mais importantes do arcabouço metodológico da medicina contemporânea, que é a determinação de causalidade no ambiente clínico (e a forma como a Epidemiologia Clínica operacionalizou esse conceito), se formou ao longo da segunda metade do século XX. Antes uma pequena digressão sobre causalidade. 
A decisão de privilegiar o conceito de causa é intencional. A definição de causalidade, o conceito de causa em ciência médica, deveria ser considerada como objeto de uma investigação separada. Importaria remontar aos gregos, à metafísica e à física aristotélicas. Compreender como a relação entre a causa e o efeito nos fenômenos observados na natureza assumiu, após o Renascimento, o status epistemológico de Verdade Científica (Koyré, 1982; Koyré, 1986; Bachelard, 1976). Entretanto, isso seria uma tarefa que definitivamente escaparia radicalmente dos objetos desse estudo. Optei, contudo, por realizar em capítulos anteriores uma tentativa de descrever a "Teoria da Causalidade" da tradição empirista inglesa e como ela se relaciona com o método científico contemporâneo, em particular com a metodologia científica aplicada à clínica.

É importante destacar que essa proposta de trabalho de crítica, descrito no parágrafo anterior, já foi magistralmente realizada, cada um a sua maneira, por epistemólogos eminentes como Koyré, Feyrabend, Thomas Khun entre outros, e o aprofundamento dessas questões certamente provocaria um desvio de conseqüências imprevisíveis para a defesa da argumentação fundamental dessa tese. Se esse caminho fosse trilhado, nos afastaríamos da interpretação histórica e nos aproximaríamos demais de uma análise epistemológica formal, o que como já foi dito, não nos interessa. Por enquanto basta assumir, sem demonstrar, que a causalidade é o alicerce da verdade em medicina. Apesar de não haver interesse em aprofundar a descrição desse ponto, vale a pena citar um exemplo da própria área que está sendo discutida, os fundamentos da Epidemiologia Clínica: o que é um ensaio terapêutico senão a refutação através de instrumentos matemáticos da hipótese de que uma determinada intervenção, digamos $X$ ou droga $A$, não é a causa do evento $Y$, ou digamos, a melhora de uma doença? Defendo que é fundamentalmente de "causa" que trata a nova ciência médica.

\section{Relação entre Verdade e Poder}


Para abordar esse assunto numa perspectiva que ligue as regras de cientificidade da medicina com as barreiras contra o fim do monopólio na área terapêutica há que se tentar entender os efeitos que os sistemas de produção de verdade produzem em uma sociedade. É por esse caminho que pretendo definir o que chamei de quarta barreira. Produzem-se verdades a todo instante. A discussão desse assunto nos remete de volta à obra de Michel Foucault sobre a relação entre saber e poder. Vou discorrer brevemente sobre essa análise (Foucault, 1975; 2004; 2005b; 2005c; 2006; 2008a; 2008 b).

Segundo Foucault, as verdades produzidas por uma sociedade, inclusive as verdades de natureza científica, não podem ser dissociadas do poder e dos mecanismos de poder. Essa relação é bidirecional (se é que esse termo se aplica a esse tipo de discurso). Ao mesmo tempo em que os mecanismos de poder tornam possíveis ou introduzem a produção de discursos verdadeiros, estes têm efeitos de produção de poder, e esta complicada relação permeia de várias formas as relações entre os homens dentro de uma sociedade. Um aspecto interessante da análise do poder em Foucault é que ele desloca a noção de poder dos efeitos de dominação exercidos por entidades como Estado, ou seus aparelhos repressivos, como a polícia ou a justiça. O poder para ele é exercido em níveis muito mais periféricos, ele é exercido dentro do relacionamento de um casamento, tanto do homem em relação à mulher quanto da mulher em relação ao homem. Ele é exercido nas salas de aulas, nas empresas, na família, etc... Ele é, e isso nos interessa particularmente, exercido entre aqueles que sabem e aqueles que não sabem. No seio de uma sociedade há milhares de enfrentamentos, de pequenas lutas que se caracterizam como relações de poder. As verdades proferidas pela ciência fazem parte desse contexto de relação de poder. A ciência produzida pela indústria farmacêutica também faz parte desse tipo de relação.

Se por um lado é verdade que essas pequenas relações de poder freqüentemente são comandadas do alto, pelos grandes poderes do Estado ou do capital, o que poderia ser descrito como um sistema de dominação que um grupo exerce sobre outro, por outro lado é preciso reconhecer que esse sistema ocorre também no sentido inverso, ou seja, as pequenas relações de 
poder que ocorrem a todo instante constroem condições de possibilidade para que esse grande sistema de dominação consiga funcionar adequadamente. Nas palavras do próprio Foucault, em uma entrevista concedida em 1977: "O que seria o poder do Estado, aquele que impõe, por exemplo o serviço militar, se não houvesse em torno de cada indivíduo, todo um feixe de relações de poder que o liga a seus pais, a seu patrão, a seu professor - àquele que sabe, àquele que Ihe enfiou na cabeça tal ou tal idéia?"

Essa forma de ver o poder e sua relação como saber acarreta algumas conseqüências importantes que nem sempre são inteiramente discutidas, ou plenamente compreendidas. Freqüentemente confunde-se essa não muito simples relação com uma certa subjetivação das relações de poder, algo como o amor inconsciente do escravo pelo seu senhor. $O$ uso de esquemas psicológicos, freqüentemente se misturam às interpretações do conceito foucautiano de poder, o que faz com que freqüentemente esse interessante instrumento de pensar as relações entre os homens se reduza novamente à uma análise tradicional e limitada de um exercício do poder exclusivamente relacionado à interdição e à negatividade. E é exatamente esse ponto que Foucault contesta, e com uma certa veemência, nas análises tradicionais do poder.

Essa redução do poder exclusivamente à lei da interdição, seja no modelo do determinante da infra-estrutura econômica, seja no modelo da análise do poder repressivo dos aparelhos do Estado, ou seja, ainda no modelo da subjetividade das relações de poder numa sociedade, acaba desempenhando três papeis principais, que, segundo Foucault, devem simplesmente ser excluídos das análises sociológicas. Esses três pontos são: 1) a visão de que o poder se exerce de forma homogênea, seja qual for o domínio em que ele se apresenta, na família, na escola, no meio médico, 2) a noção de que o poder é sempre e necessariamente de natureza restritiva, ou seja, que ele sempre se exerce através do negativo, do "dizer não", 3) a noção de que a operação fundamental do exercício do poder se manifesta como um ato de fala, a enunciação de uma lei, de um discurso de interdição. 
É contra essa visão de um poder homogêneo exclusivamente restritivo e enunciado por atos da fala que a obra de Michel Foucault se insurge. $O$ desenvolvimento desse tema, na profundidade que ele merece, escapa em muito aos objetivos desse trabalho. Nesse momento importa dizer que, independentemente da posição que se coloque em relação à tese de Foucault sobre o poder e sua relação com o saber, seja concordando, seja ao contrário, refutando-a, ninguém discorda que esse é o cerne do pensamento desse importante autor, e que nenhuma análise contemporânea sobre o assunto pode prescindir de suas reflexões. Outra consideração que deve ser feita antes de voltarmos às questões das barreiras é a de que para elaborar esse trabalho, parti da noção de que há uma relação estreita entre o saber médico resultante do edifício teórico construído em torno da metodologia científica aplicada à terapêutica que emergiu após a década de sessenta, e a manutenção de um sistema de monopólio com todas as suas conseqüências, boas ou más, que caracteriza a indústria farmacêutica. Há uma relação entre a Epidemiologia Clínica e a manutenção do monopólio no setor farmacêutico.

Resta saber como isso pode ser uma barreira ao livre mercado na terapêutica médica. Talvez com a explicação que sé seguirá fique mais claro o motivo da digressão sobre o conceito foucaultiano de poder.

As diversas crises que discutimos anteriormente, em particular as exigências de comprovação de eficácia e segurança demandadas pela agência regulatória americana, a partir da década de sessenta, teve como conseqüência na área de medicamentos, ao contrário da maior parte dos outros segmentos econômicos, um aumento substantivo das exigências regulatórias. Essas exigências tomaram a forma de comprovação empírica de eficácia através de metodologia comparativa. Mostramos que, ainda no inicio da década de setenta, eram raríssimos os estudos científicos na área terapêutica, seja para o registro de novas drogas ou não, que utilizavam essa metodologia. Mostramos que a principal característica econômica do segmento farmacêutico é a prática comercial através do monopólio, e que esse sistema estava sendo seriamente questionado desde o final da década de cinqüenta. Mostramos que, para defender o direito de exercer o monopólio, quatro barreiras foram impostas à 
sociedade, três delas já foram suficientemente abordadas, a quarta, que provisoriamente denomino, por falta de melhor expressão, de "o novo saber médico" será descrita, finalmente, nos parágrafos abaixo. Essa descrição, espero, poderá levar, no futuro, a novas e mais precisas denominações. A quarta barreira poderá mudar de nome, dependendo da ótica de sua abordagem.

Sempre que um problema médico é equacionado no formato de um ensaio clínico comparativo, sempre que esse saber se materializa em decisões de caráter prescritivo, sempre que o gabarito de legitimação científica de uma prática médica se ancora nessa metodologia, sempre, em todos esses casos, a quarta barreira se impõe. Julgo importante colocar essas assertivas no contexto das minhas reais intenções com o objetivo de evitar desvios de interpretação.

Não estou dizendo que o novo saber médico é composto por uma substância particular que, ao ser aplicado na vida real coloca em ação uma série de mecanismos que fazem com que o mercado terapêutico permaneça monopolístico e injusto. Não é isso que quero dizer. O que quero dizer é que o saber científico resultante do método empírico comparativo, e que originalmente se prestava a construir provas legais e científicas de eficácia e segurança de uma nova droga, passou a se constituir como arcabouço legitimador de verdade científica da medicina. Não penso que seja o único, mas certamente defendo que é um importante determinante da constituição histórica desse arcabouço. Esses critérios de produção da verdade não são, talvez nunca tenham sido, impostos de cima para baixo, ou, dizendo de outra forma: das necessidades das indústrias de preservar seus territórios monopolizados, para os que exercem a medicina. A formação e a manutenção dessa relação entre o saber e o poder sempre foi, e continua sendo, uma espécie de acordo entre as partes. A necessidade de um processo de racionalização atendia (e atende) ao princípio de utilidade tanto da indústria farmacêutica quanto dos órgãos reguladores e, finalmente, dos próprios médicos praticantes. Nessa relação entre o saber produzido pela metodologia do novo saber médico e o poder exercido pela própria medicina, pelas 
empresas farmacêuticas e de equipamentos, e finalmente pelo próprio Estado, não é possível identificar-se nitidamente uma relação do tipo dominador e dominado, mestre e escravo. Esse relacionamento é de natureza mais complexa, mais difícil de delimitar fronteiras claras.

A prática médica ao se subordinar ao saber teórico construído a partir dos anos sessenta, passou a ser, ela própria, uma poderosa barreira a uma verdadeira livre concorrência no mercado de medicamentos. $O$ ensino médico segue 0 mesmo caminho. Ambos têm como conseqüência prática a diminuição da capacidade crítica dos profissionais que exercem a medicina com relação aos seus próprios atos. E aqui confluímos inevitavelmente para uma outra questão importante e que também terá que ser abordada apenas superficialmente para não escaparmos, nesse momento, do foco principal. Refiro-me à questão da crítica. Abaixo esse assunto será tratado em maior profundidade.

Um outro ponto que devo deixar claro com relação a abordagem que estou realizando sobre a relação entre o conhecimento científico produzido pelo novo saber médico e as decisões de poder que permeiam a prática médica, é a questão do erro ou da manipulação do método, dos dados, da análise ou da retórica descritiva dos resultados. O que estou chamando de barreira, ou de novo saber médico, não está absolutamente vinculado a qualquer suposição de que há sempre uma intenção maligna de, através da manipulação do método, atingir-se um determinado resultado que seja do interesse de uma ou mais classes ou grupos. Ainda que não negue a existência desse tipo de prática, ela é pouco importante na minha análise. Digamos que sua importância é apenas marginal. A questão não é buscar os erros, as más intenções, os desvios de conduta que expliquem eventualmente as relações assimétricas de poder. Veremos adiante que o próprio sistema cuidou de averiguar e punir severamente todos os desvios de conduta. Esses desvios são mal vistos pela moral utilitarista e devem, quando identificados, ser severamente punidos. É o que abaixo descreverei como a etiqueta do método. A questão é exatamente o contrário, quero dizer, tentar entender como o método, quando bem aplicado, e quando seguindo a sua racionalidade intrínseca de forma estrita, passou a ser ele próprio um critério de verdade independentemente do problema clínico que 
o suscitou, que apelou para sua utilização. É nesse caso que reside o problema da crítica, ou melhor, do encobrimento da possibilidade de uma crítica esclarecedora. É essa a verdadeira quarta barreira: a ausência de crítica.

O ponto aqui que tem que ser destacado é o de que o método empírico comparativo foi desde os seus primórdios uma proposta de racionalização para que a eficácia e a segurança de uma droga nova fosse legalmente demonstrada para o FDA. A transposição dessa utilidade para a prática clínica e para os bancos escolares ocorreu de maneira paralela a esse processo. A artificialidade do ensaio terapêutico quando se compara com a multiplicidade das circunstâncias que envolvem um paciente individual é um assunto evidente por si mesmo, e, o próprio contraste dos dois cenários, sem grandes aprofundamentos analíticos, já desvela o fato óbvio de que são duas coisas distintas. Interessante mesmo é observar que, ao longo dos anos, desde a década de sessenta, essas duas coisas se fundem em uma só no formato de um novo saber médico.

Os desenvolvimentos do próprio método, o nascimento da Epidemiologia Clínica e seus vários desdobramentos teóricos e práticos (como os métodos próprios para diagnóstico, terapêutica, prognóstico, etc), além do extraordinário desenvolvimento das técnicas de análise matemática dos dados provenientes da observação clínica, defendo que ambos esses saberes construíram condições de possibilidade racionalmente justificáveis para que os resultados de um ensaio terapêutico controlado pudessem ser automaticamente considerados como úteis, ou mesmo cientificamente legítimos, no ambiente de tomada de decisão individual. Pensando na análise de Foucault e remetendo-a para a prática médica contemporânea, fica a pergunta: o que seria do poder que orbita em torno da prática médica, aquele que determina o uso preferencial de uma droga em detrimento de várias outras iguais, se não houvesse em torno de cada médico um feixe de poder que o liga a alguém ou alguma coisa que sabe mais, alguém ou alguma coisa que Ihe enfiou na cabeça tal ou tal coisa? Essa alguma coisa a que me refiro, nessa paródia às palavras do filósofo, é o que chamei o novo saber médico. É o que chamei de quarta barreira. 
Defendo que a forma como os médicos pensam sobre os problemas que têm que resolver de seus pacientes, a racionalidade de seus instrumentos de decisão, o gabarito de legitimidade do exercício de sua prática, todos esses pontos, são absolutamente determinantes para a maioria das características da prática médica: da arquitetura de uma unidade de atendimento básico, a uma decisão de compra de vacina para hepatite por parte de um Ministério da Saúde, passando obviamente pela decisão de prescrição de um medicamento para uma doença mesmo que banal e freqüente. Entender o sistema de pensamento da decisão médica pode ajudar na análise de várias facetas importantes da medicina e ajudar a construir propostas de melhora da prática médica. E a crítica? E o criticismo envolvido em todo esse processo?

\section{Introdução à questão da crítica - Uma paródia}

O renomado dicionário de filosofia de Ferrater Mora (Mora, 2004), define genericamente a palavra criticismo como a atitude que considera a realidade, ou o mundo, de um ponto de vista crítico, isto é, atitude segundo a qual não é possível, nem desejável, conhecer o mundo ou agir nele, sem uma prévia crítica, ou um prévio exame, dos fundamentos do conhecimento e da ação. Contrapõe a noção de crítica no sentido epistemológico kantiano, não apenas como uma posição na teoria do conhecimento, mas uma atitude que matiza todos os atos da vida humana. É nesse sentido geral que abordarei a minha visão particular da crítica existente, sobretudo no meio médico, à questão do novo saber médico.

Para fazer essa análise, iniciarei pela construção de algumas categorias de comportamentos de alguns profissionais de saúde, sobretudo os médicos, com relação ao método científico clínico. Será uma descrição um pouco parodiada de posições individuais e ações humanas. Será um quadro artificial e arbitrário e seguirá um modelo de plágio. Um plágio consciente e sem muita vergonha. $\mathrm{Na}$ verdade um duplo plágio. Em primeiro lugar do formalismo da análise do autor descrito anteriormente à história oficial do FDA, o historiador americano 
Hayden White, sobretudo na questão da ironia, e, em segundo lugar do lingüista búlgaro (Todorov, 2005), que servirá de âncora teórica para descrição da história do humanismo que faremos na última parte desse trabalho. $O$ trabalho desses autores ajudou na construção da descrição que se seguirá.

Essa paródia é uma invenção, um pedaço de ficção, e não há nela nenhum tipo de abordagem empírico observacional. Não foi feito um estudo sistemático para descrever comportamentos. Assumo os riscos de erros e injustiças. Meu objetivo é continuar na tarefa de construir argumentos que nos conduzam em direção à prova da necessidade de uma postura crítica em relação aos proferimentos científicos resultantes dos métodos da Epidemiologia Clínica.

A primeira categoria é a que se chamaria de: os desconfiados. Esses em geral não acreditam em nada nem em ninguém, muitas vezes nem neles próprios, embora na maior parte das vezes os representantes desse grupo têm de suas próprias opiniões um julgamento bastante positivo. A principal característica desse grupo é achar que praticamente tudo é resultado da manipulação de algum poder oculto que opera contra os interesses da maioria ou das classes menos favorecidas. Os "desconfiados" vêem más intenções em tudo e contam com o fato de que um dia, através de algum mecanismo, que eles próprios não têm exatamente um consenso sobre qual mecanismo será esse (uns acham que será o desenvolvimento científico, outros que será um sistema político mais participativo, outros ainda que será um arcabouço jurídico mais severo, e ainda até há os que acham que será após um processo revolucionário aos moldes da revolução francesa), as coisas vão acabar entrando nos eixos, definindo, obviamente, como eixo os seus próprios pensamentos. Há um interessantíssimo grupo entre os desconfiados, são os cínicos. Esses têm a mesma visão dos desconfiados, porém já não mais acreditam que algo possa ser feito, seja em que instância for para "consertar o mundo".

O segundo grupo, absolutamente majoritário hoje em dia, é o grupo dos otimistas. Estes têm como principal característica uma crença irrestrita nas potencialidades do novo saber médico. Trata-se, em verdade, de um grupo bastante heterogêneo quando se considera a forma como interpreta e utiliza o 
conhecimento produzido pelo novo saber médico. Pode-se dizer que há três subgrupos dentro dos otimistas. Os primeiros são aqueles que simplesmente aplicam na prática os resultados que lêem (ou ouvem falar) sem grandes considerações sobre se o método foi utilizado dentro das melhores regras possíveis. A maior parte desse grupo tem consciência de que o método sempre tem suas limitações, mas eles costumam achar as discussões em torno desses problemas algo enfadonha, pouco prática como eles dizem, e que os problemas dos pacientes, ou às vezes, deles próprios, têm que ser resolvidos com o que se tem disponível nas mãos. O segundo tipo que classifico dentro do segundo grupo, o dos otimistas, é o que chamaria de grupo dos epistemólogos. Esse é um subgrupo muito interessante, pois eles sempre têm algo a dizer sobre o método empregado em qualquer estudo. Ou o número de pacientes não é o suficiente, ou os critérios de elegibilidade não são adequados ou o instrumento estatístico empregado não foi o melhor ou, e esse é o melhor comentário, o "desenho" do estudo não é poderoso o suficiente para responder ao objetivo primário que motivou o estudo. $O$ que chama a atenção nesse subgrupo é que eles realmente pensam que toda questão se resume ao aprimoramento da aplicação do método. Com um artigo científico nas mãos são hábeis e ágeis interpretadores de textos. Seu otimismo se manifesta, sobretudo, na expectativa que criam de que se seus comentários forem implementados, o assunto estará liquidado, a dúvida será e estará definitivamente resolvida. O terceiro e último subgrupo lembra em alguns pontos os desconfiados, a diferença é que eles sempre usam os instrumentos de análise dos epistemólogos, poderiam até ser chamados de "os epistemólogos de não". Através do mesmo escrutínio sobre o método, em geral usando as mesmas variáveis críticas, concluem pela inevitável manipulação dos resultados. Contudo, ao contrário dos outros dois grupos com os quais poderiam se confundir, eles acreditam que, se as pesquisas fossem patrocinadas por agentes independentes, ou se não fossem absolutamente patrocinadas e emergissem espontaneamente de dúvidas acadêmicas genuínas, certamente os resultados teriam maior aplicabilidade prática. A medicina seria mais científica, assertiva, justa e libertadora. 
O terceiro grupo é o grupo dos humanistas. Esse também é um grupo bastante heterogêneo e será descrito em maiores detalhes, como disse no início dessa parábola, na última parte desse trabalho, quando analisarmos, baseado no trabalho do lingüista Tzevetan Todorov, a questão da humanização em medicina. Nessa parte, espero, deixarei mais claras, uma das principais motivações desse trabalho. Nesse momento vou tentar explicar como a análise que empreendi pode reivindicar um lugar junto aos críticos humanistas.

Vou iniciar a argumentação exatamente do ponto que na análise histórica não canônica, denominei de "a questão principal". Recordando: a questão principal é a defesa do monopólio. Em torno da questão do monopólio tentei construir toda uma série de evidências para mostrar que não havia no período histórico em que o novo saber médico foi desenvolvido, ou seja, nas décadas de sessenta e setenta, algo que pudesse ser considerado como uma posição consensual entre todas as partes envolvidas na discussão que se seguiu à aprovação da emenda Kefauver-Harris. Professores de medicina, economistas, médicos praticantes, legisladores, representantes da indústria farmacêutica e membros do governo, debatiam calorosamente com poucos pontos de convergência.

Entretanto, de dentro dessa multiplicidade de opiniões, dessas defesas heterogêneas de interesses muitas vezes radicalmente contraditórias entre si, desse enredo inarmônico e aparentemente caótico, emergiu uma nova situação que atendeu a todos os interessados. Pode-se dizer que se construiu um verdadeiro consenso na sociedade, e, que esse consenso assumiu a forma de um código de regras.

Código de Regras (A Etiqueta do método). Como fazer para produzir o novo saber médico corretamente?

Em seções precedentes, quando discutimos a questão da necessidade de capacitação científica do FDA, e, posteriormente, a questão do "drug lag" nos Estados Unidos, particularmente em relação aos países europeus, mostramos que havia uma grande demanda por um processo regulatório nos EUA que 
fosse a um só tempo mais ágil e mais científico. A demanda era: maior segurança com maior agilidade, ambos em um cenário mais previsível e articulado de uma maneira mais científica. Como se deu esse processo?

Em todo período estudado, pode-se mesmo dizer em toda a história do FDA, há um ponto que nunca deixou de ser uma reivindicação prioritária. Refiro-me à questão da estrutura da agência. Sempre, quase todos os participantes desse diálogo reclamaram que havia pouca gente contratada, estrutura física inadequada, poucos recursos para capacitação técnica do pessoal, pouco dinheiro para investimento em ciência. Achar na bibliografia sobre o assunto uma voz discordante a essa é uma tarefa extremamente difícil. Como vimos, houve até uma Audiência Pública, cuja conclusão principal foi exatamente que a agência necessitava de muito mais recursos para poder exercer seu papel na sociedade (Hutt, 1984). Uma análise da estrutura e do organograma do FDA seria extremamente exaustiva e demorada, e, mais importante que isso, demonstraria que, apesar das reclamações ainda continuarem, houve nos últimos cinqüenta anos, sobretudo nos últimos vinte anos, um aumento considerável da complexidade organizacional do FDA. Há diversos departamentos e estes são subdivididos em várias seções e subseções. $A$ área específica para o registro de novas drogas denomina-se "Center of Drug Evaluation ans Research (CDER)". Para situar a ação desse departamento na discussão que estamos empreendendo, penso que vale a pena ler o seguinte texto extraído da página da Internet do FDA: "A team of CDER physicians, statisticians, chemists, pharmacologists, and other scientists reviews the company's data and proposed labeling. If this independent and unbiased review establishes that a drug's health benefits outweigh its known risks, the drug is approved for sale. The center doesn't actually test drugs itself, although it does conduct limited research in the areas of drug quality, safety, and effectiveness standards" (Drugs, 2009).

Os cientistas e técnicos do CDER são os agentes responsáveis pela discussão de um novo plano de desenvolvimento para uma nova droga com a empresa proponente detentora de uma nova substância, por seu acompanhamento ao longo do processo de pesquisas em todas as fases, pela interpretação dos 
dados científicos, pela conferência da integridade dos dados, e finalmente pela liberação para comercialização e marketing dessa droga. Trata-se de uma área enorme e de grande responsabilidade. Há uma pequena história que deve ser contada para explicar como essa área se tornou tão complexa e aparelhada.

Em 1992, foi aprovada no Congresso Americano uma lei denominada "The Prescription Drug User Fee Act (PDUFA)". Essa lei foi assinada pelo Presidente George Bush e vigora até os dias de hoje, após ter sido reavaliada e reaprovada em 1997, 2002 e 2007. O fundamento da lei é relativamente simples de entender: ela autoriza o FDA a coletar recursos diretamente da iniciativa privada, das empresas que estão solicitando novos registros de novos produtos. Esses recursos são utilizados para pagar os salários dos cientistas que avaliam os processos de New Drug Application (NDA). Em 1992 o orçamento do CDER era de US\$120 milhões, cem por cento de origem pública. Em 2004 o orçamento era de US\$ 436 milhões, sendo que US\$ 232 milhões, ou seja, 53\% tinham origem nas empresas que usavam os serviços do CDER. Coincidência ou não, foi a partir desse período que o código de regras que vamos discutir a seguir foi implementado (Avorn, 2007).

Esse código de regras estava em germinação e, como ninguém sabia exatamente como fazer as coisas, a indústria técnico-científica ligada à medicina assumiu o papel de secretária da discussão (Dukes, 2005). Quem define a pauta e escreve a ata, em geral, tem mais voz numa discussão não consensual, onde os interesses podem ser diametralmente antagônicos. Para descrição desse código duas referências são essenciais: A primeira é a denominada "International Conference Harmonization (ICH)" (International Conference Harmonization (ICH), 2009), e a segunda é, nada mais nada menos que, o "Code of Federal Regulation (CFR)" em seu capítulo número 21 (CFR - Code of Federal Regulation Title 21, 2009), onde as regras práticas, incluindo exigências e penalidades para a condução de um estudo clínico nos Estados Unidos estão estabelecidas. Interessantemente, pouco se discute nesses textos aspectos de natureza metodológica, mas discute-se, isso sim, e em nível de detalhes que ao mesmo tempo impressiona e fascina, como 
proceder para que a legitimidade científica e jurídica de um estudo clínico seja assegurada.

O nascimento do ICH aconteceu em 1990, mas foi precedido por toda uma discussão que remonta à década de 60 . A primeira reunião foi realizada em Bruxelas, na Bélgica, e foi organizada e secretariada pela poderosa "International Federation of Pharmaceutical Manufactures Association (IFPIA)". Seu objetivo explícito era racionalizar e harmonizar a regulamentação de novos medicamentos em todo o mundo. Cumpre citar que nessa reunião havia representantes apenas dos Estados Unidos, da Europa Ocidental e do Japão. Esses países, que detêm ainda hoje praticamente cem por cento das patentes de novos medicamentos no mundo, estavam (e ainda estão) particularmente preocupados com três aspectos: 1 ) os custos crescentes para o desenvolvimento de uma nova droga, 2) a disparidade das exigências regulatórias nos vários países de mercado robusto em termos de faturamento, e, 3) finalmente, usando a retórica da própria Conferência, a preocupação de atender a expectativa do público consumidor no sentido de reduzir o tempo em que drogas seguras e eficazes estariam disponíveis para o tratamento de pacientes portadores de doenças. Nessa primeira Conferência formou-se um comitê diretivo que, desde então, se reúne duas vezes por ano em locais alternantes, mas sempre nos EUA, Japão ou um país da Europa Ocidental. Segundo Dukes (Dukes, 2005), a partir da primeira reunião da $\mathrm{ICH}$ a indústria passou a reivindicar para si própria a formulação ativa das regras que garantissem os direitos e a segurança da população, mas, que, ao mesmo tempo, buscassem determinar regras que fossem aceitas de acordo com seus próprios princípios de utilidade.

$\mathrm{O} \mathrm{ICH}$ tem vários capítulos, de qualidade de produção a marketing. Um, em particular, nos interessa, este denomina-se ICH-GCP (Good Clinical Practice). É esse capitulo que trata das regras para condução adequada de um estudo clínico, e é ele que constrói a abertura para descrição da última referência central de natureza jurídica que utilizei. Trata-se do referido CFR. O "Code of Federal Regulation" é a codificação no Registro Federal Americano das regras gerais e permanentes ditadas pelos Departamentos do Poder Executivo e pelas 
Agências Regulatórias ligadas ao Governo Americano. São as leis que de fato regulam a sociedade americana em um nível operacional. Para se construir uma usina de energia em uma reserva ambiental, é em um dos capítulos do CFR que se saberá quais as regras e exigências que terão que ser cumpridas. Da mesma forma, se se quer desenvolver um novo medicamento, é no capítulo 21 do CFR que se encontrarão as regras operacionais. Defendo a tese de que não é pura coincidência temporal o fato de que as principais diretrizes do $\mathrm{ICH}$ GCP já estavam previstas no capítulo 21 do CFR, e que este foi construído seguindo as diretrizes impostas pela técnica de governar regida pelos princípios pragmáticos do neoliberalismo. Além disso, é interessante notar que foi somente após a definição de um marco regulatório suficientemente sólido e estável nos Estados Unidos que essa normatização prática passou a ser discutida com o resto do mundo, inicialmente nos países com capacidade tecnológica para descobrir novos medicamentos, e depois (hoje em dia) com o resto do mundo.

Chama a atenção o fato de que toda a questão especificamente científica, como desenho de estudo, análise estatística, etc., não faz parte nem remotamente do conteúdo nem do GCP, nem do CFR 21. Uma análise histórica superficial mostraria que nem deveria, uma vez que o espectro de atuação desses documentos refere-se mais a questões de natureza legal do que propriamente científica. As regras do GCP servem fundamentalmente para assegurar que as diretrizes científicas determinadas por deliberações consensuais entre o FDA e a indústria farmacêutica sejam implementadas de uma forma que legitime os direitos dos resultados provenientes dos estudos científicos, e, ao mesmo tempo, garantam à sociedade que desvios de conduta ética, como, por exemplo, fraudes ou um cuidado com a segurança dos sujeitos de pesquisa, sejam, se perpetrados pelos investigadores, punidos adequada e exemplarmente.

Além dos aspectos descritos muito superficialmente no parágrafo precedente, ou seja, fraude e segurança, que são os mais importantes, vários outros aspectos são minuciosamente descritos nesses documentos. Pontos como: manejo e armazenamento da droga sob investigação, estrutura de reporte a um 
Comitê de Ética, monitorização dos dados, auditoria por parte da agência regulatória, deliberação de responsabilidades, assinaturas de Termo de Consentimento Livre e Esclarecido, armazenamento dos dados, obrigatoriedade de se continuar provendo tratamento após o encerramento formal do estudo conforme regras acordadas no protocolo, etc...são previstos tanto no ICH-GCP quanto no CFR 21, e que, nesse último, conseqüências de natureza punitiva e legal estão previstas para quem não agir conforme a etiqueta do método.

Portanto, toda essa regulamentação faz parte, assim como as regras científicas oriundas da metodologia analítica da Epidemiologia Clínica, do conjunto de normas a serem seguidas, após aceitação consensual entre todas as partes, para que um determinado proferimento seja considerado como legítimo legal e cientificamente.

\section{A legitimação da racionalidade científica do novo saber médico}

O consenso sobre o novo saber médico (tanto em seus aspectos científicos quanto em sua face legal), e que teve que ser discutido e negociado entre as partes envolvidas assumiu uma determinada forma. Essa forma atende a um complexo conceito de racionalidade que merece uma breve discussão. $O$ autor fundamental aqui é o alemão Jürgen Habermas (Habermas, 2002; 2003 a, 2003b; 2006; Repa, 2008). Esse autor fundamenta sua crítica particularmente sobre as ciências que objetivam o conhecimento além de um aspecto puramente instrumental, entretanto que avança de forma bastante complexa na elucidação dos aspectos filosóficos e epistemológicos que contribuem para o processo de construção do conhecimento. Na perspectiva habermasiana a ausência de uma auto-reflexão na construção de um conhecimento impede que as ciências desenvolvam na sociedade seu caráter emancipador.

Há que tentar entender o pensamento de Habermas como uma adaptação da autocompreensão da teoria crítica, em cuja origem se encontra, sobretudo o modelo de crítica marxista da economia política. As diferenças têm como 
pressuposto um novo diagnóstico do capitalismo. Sob as condições de um capitalismo tardio não é mais exatamente a economia política, mas a ciência construída à maneira positivista que passa a se constituir como alvo de uma crítica ideológica. O crescente aumento da cientificização e da técnica na sociedade tem como conseqüência uma substituição da "práxis" pela "técnica", e, esse processo desencadeia o interesse de Habermas em retomar uma análise da teoria do conhecimento, só que não na perspectiva, como disse, da economia política, mas na perspectiva de uma crítica da autocompreensão positivista da ciência. Uma crítica à ciência, seria uma crítica à própria sociedade.

Uma teoria da verdade como consenso lingüisticamente articulado é a proposta de Habermas para fazer frente a uma teoria da verdade como correspondência ou cópia, segundo os princípios do positivismo. Há complexas articulações com a história da filosofia, sobretudo com a filosofia que emana da tradição do idealismo alemão, cujo aprofundamento escapa em muito os objetivos desse trabalho. Vou apenas tentar situar, ainda que superficialmente, a noção de consenso lingüisticamente articulado com o problema concreto que estamos trabalhando. Realmente, é impossível abordar esse complexo pensamento em poucos parágrafos sem incorrer em erros e um inevitável reducionismo que pode ser comprometedor. $\mathrm{O}$ uso do pensamento desse autor na matéria prima dessa tese, poderia talvez, ser o objeto de uma nova tese. A divisão que fiz dos componentes do ato de fala é apenas e exclusivamente didática. Nenhum lingüista, ou mesmo apenas um interessado pelo assunto, subscreviria a divisão no formato que fiz como real. Já Roman Jackobson, o mesmo lingüista que citei para referenciar a obra de $\mathrm{H}$. White, já havia desenvolvido a tese da indissociabilidade dos planos locucionários e ilocussionarios. Portanto, antes de prosseguir numa breve descrição do pensamento de Habermas, vou fazer um breve resumo do que pretendo com mais essa incorporação do discurso filosófico ao corpo da minha argumentação:

o conceito de razão comunicativa de Habermas ajuda a perceber como a linguagem científica construiu um consenso que respondeu às quatro crises, fazendo com que uma certa discursividade científica (a da epidemiologia 
clínica), ocupasse o lugar de discursos cujas pretensões de validade deveriam dirigir-se ao plano normativo, dado o caráter econômico e político das questões em jogo, e, ademais, se expandindo da esfera da regulação da atividade da indústria farmacêutica para o conjunto das práticas de saúde

De uma maneira geral, Habermas afirma que o sentido de verdade de uma proposição não pode ser clarificado sem uma referência a discursos nas quais examinamos a pretensão de validade presente nessa proposição. O que decide afinal de contas pela verdade dessa proposição não tem a ver com a evidência da experiência, mas com o curso da argumentação. Em uma discussão científica certamente se pode recorrer à experiência num sentido metodológico, isso é por meio de experimentos e observações controladas, mas, mesmo nesses casos, é necessário recorrer a interpretações que, por sua vez, dependem de discursos. Uma pretensão de verdade fundada na experiência não é de forma alguma uma pretensão automaticamente fundamentada. Para se resgatar e sedimentar uma pretensão de verdade sobre um assunto há que, antes de tudo, oferecer razões, e, segundo, determinados procedimentos, de modo que essa pretensão seja intersubjetivamente reconhecida, isto é, considerada justificada. O resgate argumentativo das pretensões de validade é, segundo Habermas, um conceito normativo e isso significa que os critérios que estabelecem um discurso como verdadeiro, formam, basicamente um consenso fundamentado.

É claro que, nessa discussão, considera-se a possibilidade de assimetrias e coerções, entretanto, a concepção de verdade numa perspectiva prática somente se configura em uma situação ideal de fala que exclui as distorções sistemáticas da comunicação. Uma estrutura de comunicação que não gera coerções para seus participantes oferece a todos a chance de escolher e executar os atos de fala. Nessa perspectiva a única coerção válida é aquela do melhor argumento, e o único fator motivacional aceitável é a busca cooperativa pela verdade. $O$ melhor argumento, por sua vez, é aquele que tem a motivação racional. A partir daí começa-se a definir racionalidade não através de dados ou métodos, mas através de um processo de natureza social e que envolve a construção de um caminho dialógico de busca consensual da verdade. 
Para se continuar na compreensão do conceito de racionalidade de Habermas há que aprofundar um pouco mais a noção de ato de fala. O ponto de partida para isso é a pressuposição de que todo participante de uma ação orientada ao entendimento intersubjetivo sobre algo no mundo tem que levantar em cada ato de fala quatro pretensões de validade e supor que cada uma delas possa ser resgatada. O reconhecimento mútuo dessas quatro pretensões e sua universalidade formam um consenso de fundo para os processos de entendimento recíproco.

Essas quatro pretensões universais de validade são: 1) a inteligibilidade das orações, 2) a verdade do seu conteúdo proposicional, 3) a justeza normativa do proferimento em relação a um contexto de normas compartilhadas, e, finalmente, 4) a veracidade com que cada um expressa suas intenções. Em uma comunicação perturbada o consenso de fundo pode ser questionado sob cada um desses aspectos de validade. Pode-se questionar a inteligibilidade das orações, a verdade do enunciado, a justeza normativa do proferimento, ou a veracidade das intenções expressas do falante. Esses conceitos formam o que Habermas chama de "base de validade da fala", e a reconstrução desta, a que se destina a pragmática da comunicação, associa a cada uma das pretensões de validade um tipo ideal de ato de fala: os constatativos (afirmar, negar, duvidar, etc...) para a pretensão de verdade, os regulativos (ordenar, pedir, proibir, permitir, prometer, etc...) para a pretensão de justeza normativa, ou os expressivos (esperar, temer, gostar, confessar, etc...) para a pretensão de veracidade.

Antes de abordarmos como se efetiva essa classificação de atos de fala, e como esse pensamento se articula com a argumentação desse trabalho, convém explicitar melhor o próprio conceito de ato de fala na perspectiva habermasiana. O essencial do conceito, introduzido no contexto da filosofia analítica e que remonta ao pensamento de Wittgenstein acerca da relação entre o significado das expressões lingüísticas e o seu uso nas práticas cotidianas, consiste no fato de que o falante, com o ato de expressar-se, efetiva a ação representada pela expressão. $O$ exemplo mais didático, quero dizer, 
mais fácil de entender, é o da promessa: ao fazer uma promessa o falante propicia uma relação interpessoal constituída de expectativas recíprocas. A Teoria dos Atos da Fala se centraliza na explicação dessa capacidade de estabelecer relações interpessoais, que foi denominada por um lingüista chamado Austin de "força ilocucionária". Em conjunto com o ato locucionário, que consiste basicamente em se dizer algo, algo que se esgota no componente proposicional, acaba, o somatório dos dois, ato ilocucionário e ato locucionário, formando a estrutura do ato de fala explicito.

Habermas se apropria dessa distinção entre o componente ilocucionário (performativo), e o componente locucionário (formal da linguagem), descrevendo uma dupla estrutura do ato da fala, de uma forma que o componente ilocucionário serve para estabelecer um modo de comunicação entre o falante e o ouvinte, enquanto o locucionário serve para comunicar algo . Essa dupla estrutura dos atos da fala, constitui, portanto, dois planos distintos: o da intersubjetividade, em que o ouvinte e o falante estabelecem através de atos ilocucionários as relações que lhes permitem entender-se entre si, e o plano das experiências das coisas em si, sobre as quais, em cada uma das quais, eles querem se entender por meio da função comunicativa estabelecida no plano da intersubjetividade. Em resumo: para Habermas, não é possível um entendimento a respeito de objetos independentemente do entendimento sobre o sentido pragmático das orações referidas aos objetos.

Esses dois planos (locucionário e ilocucionário), é importante destacar, realmente se diferenciam, pois é possível desconectar o componente ilocucionário e o locucionário, de uma determinada forma que, um mesmo conteúdo proposicional seja utilizado em atos de fala distintos. As proposições do método científico clínico, desenvolvido a partir dos anos sessenta, pode ensejar, dependendo do acordo intersubjetivo entre os falantes que o utilizam, critérios de validade e construções de verdade de alguma forma distintos. $\mathrm{Na}$ história que contamos sobre a construção de regras racionais para a construção de um critério científico para eficácia e segurança de uma droga, em que diferentes interesses e visões, buscavam se entender para conseguir se comunicar, o componente ilocucionário, a intersubjetividade com pretensões 
de validade e a busca racional de um consenso, desempenhou um papel fundamental no sentido de possibilitar que posições antagônicas de indivíduos, ou grupos pudessem se entender mutuamente.

Defendo a tese de que as proposições formais do novo saber médico, constituído como ato locucionário, construíram a base de comunicação que possibilitou uma ação racional orientada ao entendimento intersubjetivo. $O$ componente proposicional resultante da Epidemiologia Clínica (ou dos métodos comparativos analisados matematicamente) representa a linguagem comum que possibilitou o consenso entre as partes envolvidas na questão da solução das várias crises dos anos sessenta e setenta. Os médicos, a comunidade acadêmica, os economistas, a indústria farmacêutica, o Estado, os legisladores, e a sociedade como um todo, articularam-se em torno da objetividade das regras científicas a fim de construir um critério racional de verdade. Este critério persiste até hoje, e é ele que se encontra na base de todos os discursos científico, legal e econômico da prática médica.

Há ainda que avançar mais um ponto na noção de racionalidade de Habermas. Somos forçados a isso pela analogia que criamos entre a história do novo saber médico e a razão comunicativa. A questão é que os atos de fala constatativos se relacionam com os fatos do mundo objetivo de um modo diferente daquele em que os atos de fala regulativos se relacionam com 0 mundo social das normas. As normas vigentes têm uma certa autonomia em relação aos atos de fala regulativos, o mesmo não pode ser dito em relação a uma proposição descritiva e atos de fala constatativos. Isso quer dizer que não há "verdades" no mundo objetivo que sejam independentes dos atos de fala, mas, há normas no mundo social que podem e são consideradas válidas independentemente dos atos de fala regulativos.

Conceitualmente, o mundo objetivo dos fatos independe dos atos de fala constatativos, assim como independe do observador. As coisas observadas não têm em si nenhuma pretensão de verdade. O mundo social, por sua vez, está sempre relacionado com pretensões de validade normativa que the são constitutivas. As relações sociais precisam se reproduzir constantemente por 
meio da linguagem. Conseqüentemente há uma dependência recíproca entre linguagem e mundo objetivo. A dependência consiste em que os atos de fala regulativos se referem de modo derivado às normas sociais vigentes, e estas possuem pretensões de validade que devem ser resgatadas discursivamente por atos de fala para que se reproduza sua legitimidade.

Conseqüentemente, uma ordem normativa vigente pode ser questionada em discursos práticos, o que definitivamente não acontece com a natureza enquanto tal, mas sim, com as interpretações teóricas acerca dela.

Transpondo essa discussão para nossa história, podemos dizer que, diante das crises econômica, científica e institucional que o mundo vivia nos anos sessenta e setenta, as normas sociais que regulavam a sociedade ocidental, refiro-me em particular ao pragmatismo e à moral utilitarista, passaram por um amplo debate e rediscussão de seus fundamentos e valores. A utilização dos atos da fala constatativos na perspectiva do saber médico, apesar de matéria prima fundamental para a construção de um consenso intersubjetivo, ocorreu de forma derivada às normas sociais vigentes na época, e, que de alguma forma se buscava preservar.

Essa última assertiva enseja uma questão fundamental no pensamento de Habermas e que é extremante importante para nossos objetivos. Trata-se da discussão em torno do ceticismo em relação à capacidade de fundamentação e crítica das normas de ação. Há na teoria de Habermas, a partir desse ponto, uma interessante incursão na teoria psicanalítica, posteriormente revista e substituída pela do diálogo na busca do sentido emancipador de sua teoria crítica, cujo objetivo é construir o arcabouço teórico que sustenta a conclusão de que, um processo de auto-reflexão, pode construir condições de possibilidade de emancipação do indivíduo. Segundo ele, uma reflexão bem sucedida promove as condições do resgate discursivo de uma pretensão de verdade.

Entretanto, ao assumir esse ponto, abro espaço para a inserção desse trabalho, e da sua retórica argumentativa, no grupo dos humanistas. Ao 
assumir que a norma moral derivada do utilitarismo conduziu o processo de utilização da racionalidade científica como fundamento do novo saber médico, assumo também, que essas normas devem permanentemente passar por um teste de universalização para serem aceitas. Abre-se a possibilidade da utilização desse trabalho para promover uma auto-reflexão crítica, por todos os implicados e interessados, com o objetivo de reconstruir uma nova e mais humana racionalidade médica.

Reitero que a compreensão do pensamento de Habermas, assim como o de Foucault, não é o objetivo desse trabalho. Apenas uso-os! Eles são uma muleta para meus argumentos. Voltemos então à defesa de minha reinvidicação ao status de humanista.

\section{Considerações Finais - Outros desdobramentos}

A defesa intransigente da proteção conferida pela lei de patentes parte de um princípio prático inquestionável, quando se aborda o problema numa perspectiva histórica: é muito pouco provável que algum agente econômico se dispusesse a investir os enormes recursos financeiros que são necessários em uma inovação tecnológica na área de medicamentos, se não tivesse assegurado de alguma forma institucional e legítima, o retorno do seu investimento. Sem esse estímulo, muitos reais avanços no tratamento de doenças simplesmente não teriam acontecido. Defendo que isso faz parte integrante da história do humanismo.

É preciso entender que os mercados de uma maneira geral, e o mercado terapêutico não é diferente, operam sempre de uma forma que garanta que os seus objetivos sejam alcançados, que sua utilidade seja maximizada. Isso significa que eles operam sob o princípio da escassez. Produtos raros e escassos têm mais valor do que os produtos amplamente disponíveis. Dentro dessa perspectiva, a exclusividade de mercado e os preços mais altos possibilitados pela proteção patentária funcionam como uma recompensa pelos riscos assumidos por aqueles que financiam as novas tecnologias. Essa é a 
regra. Penso que uma crítica conseqüente e emancipadora a essa regra, independentemente de qualquer postura ideológica ou filosófica, deve partir da ciência de alguns importantes fatos reais. Vamos a eles:

O mercado farmacêutico mundial é estimado no valor aproximado de quatrocentos bilhões de dólares. Os Estados Unidos, a União Européia, e o Japão representam oitenta por cento desse total, cabendo a todo o resto do mundo, inclusive a América Latina e o Brasil, menos de vinte por cento. Um sistema de patentes forte e operativo guarda uma relação direta com os instrumentos de pesquisa e desenvolvimento na área farmacêutica. Isso é confirmado empiricamente pela relação direta entre margens brutas de lucro das indústrias farmacêuticas e seus gastos diretos em pesquisa científica. Estima-se que cerca de noventa e cinco por cento de todas as patentes concedidas no mundo provêm de países desenvolvidos. Nos países em desenvolvimento, como o Brasil, ainda que exista alguma capacidade inovativa, sobretudo nas áreas de medicina e agricultura, a maior parte das descobertas, provém de laboratórios públicos totalmente financiados pelos governos, e não há nesses países, nem um sistema de utilização desses recursos públicos em prol de toda a sociedade, através de um compromisso de retorno financeiro ao próprio poder público, nem um sistema de integração com a iniciativa privada para levar essas descobertas adiante em termos de desenvolvimento clínico que resulte em produtos locais. Sem contar com o fato, de reconhecimento geral, de que nossas instâncias regulatórias têm, tanto estatutariamente quanto operacionalmente, uma função predominantemente burocrática, carecendo de uma estruturação científica adequada e de inserção no desenvolvimento tecnológico do país. É na maior parte das vezes apenas um balcão de processos burocráticos, que funciona, ainda que inconscientemente, na maior parte das vezes, defendendo irrestritamente as mesmas barreiras que impedem os países não desenvolvidos de participar efetivamente do desenvolvimento tecnológico da medicina (International Intellectual Property Institute. The Pharmaceutical industry and patent system, 2003).

A ausência de pragmatismo, aliado a uma crítica de cunho moralista, fazem com que países como o Brasil sejam alijados de um processo econômico de 
alto valor agregado. Considero ser simplesmente impossível, nesse ambiente tão pouco pragmático (e pouco humano) conseguir vencer as quatro poderosas barreiras impostas pela indústria multinacional farmacêutica. $O$ Brasil, se mantidas as condições atuais, está inexoravelmente fadado a apenas participar do jogo internacional do desenvolvimento farmacêutico, um jogo multimilionário, com pequenas participações em estudos clínicos de fase III, em doenças de baixa incidência, que, a rigor, não incorporam nenhuma tecnologia, ou valor, ao nosso sistema de saúde. Talvez seja importante agregar algum humanismo, seja em que perspectiva for, em todo esse processo.

Os aspectos que descrevi como barreiras, longe de terem sido impostos aos participantes desse diálogo, foram construídos e sedimentados através de um amplo processo de debate no qual todas as vozes tiveram a oportunidade de se manifestar. Se os fatos seguiram o curso que seguiram é porque o melhor argumento conseguiu se impor através de um processo racional, e se esses fatos não são considerados ideais, somente através de um processo de crítica, para a qual espero poder de alguma forma contribuir com esse trabalho, poderá resgatar os vetores das argumentações discordantes e colocá-los novamente para o julgamento da sociedade.

Essa posição é, no meu entender, uma perspectiva fundamentalmente humanística. Além disso, tenho a ambição de tentar ampliar a alcunha de humanista, apelando para a tradição da filosofia anglo-saxã sobretudo nas figuras de David Hume e John Stuart Mill, que, ao definirem a natureza humana através das sensações, do princípio de utilidade e de um certo pragmatismo, colocam as questões da vida cotidiana sob uma perspectiva exclusivamente humana. 
Parte IV - A questão da humanização da medicina 


\section{Introdução}

Não se deve confundir a abordagem que empreendi sobre a questão da humanização em medicina com as políticas públicas de humanização em medicina. Não se deve confundir os objetivos dessa crítica, limitada a um aspecto relativamente pequeno da atuação do médico, com os objetivos extremamente amplos das políticas públicas de humanização da medicina. Não se deve confundir a importância e a expectativa de utilização prática desse estudo com a potencialidade das políticas públicas de humanização em medicina. São coisas distintas. Declaro de antemão, e novamente, que sou um entusiasta de todas as iniciativas práticas que visem a racionalização e a humanização da prática médica, e, que não me julgo sequer em condições de articular um discurso crítico consistente sobre a efetividade dessas práticas. Sua simples existência já é na minha opinião um desenvolvimento do sistema como um todo. Admiro verdadeiramente todo ser vivente que se engaja em um projeto dessa natureza e que dedica seu tempo a buscar soluções para um problema de enormes dimensões como é a questão da qualidade do atendimento médico. Na realidade, é a essa população de seres humanos que preferencialmente me dirijo, e é para eles que essa proposta de crítica foi escrita.

Abaixo farei uma transcrição dos objetivos gerais da Política Nacional de Humanização do Ministério da Saúde (Ministério da Saúde, 2004):

- Ampliar as ofertas da Política Nacional de Humanização aos gestores e aos conselhos de saúde, priorizando a atenção básica/fundamental e hospitalar, com ênfase nos hospitais de urgência e universitários;

- Incentivar a inserção da valorização dos trabalhadores do SUS na agenda dos gestores, dos conselhos de saúde e das organizações da sociedade civil; 
- Divulgar a Política Nacional de Humanização e ampliar os processos de formação e produção de conhecimento em articulação com movimentos sociais e instituições.

Na prática, os resultados que queremos são:

- Redução de filas e do tempo de espera, com ampliação do acesso;

- Atendimento acolhedor e resolutivo baseado em critérios de risco;

- Implantação de modelo de atenção com responsabilização e vínculo;

- Garantia dos direitos dos usuários;

- Valorização do trabalho na saúde;

- Gestão participativa nos serviços.

Uma simples leitura desse texto já, de per si, descredencia qualquer tentativa de exercer uma crítica a esse processo através de um segmento limitado de sua atuação como o que analisei nesse trabalho. $O$ objetivo é evidentemente muito mais amplo. Então, por que falar em humanização e humanismo, quando na verdade a matéria prima da minha análise refere-se à racionalidade do registro de novos medicamentos? Aqui temos que necessariamente voltar à introdução desse trabalho, às minhas ambições exageradas e às minhas dificuldades.

$\mathrm{Na}$ introdução antecipei que tentaria fazer uma articulação entre a prática médica e o humanismo, e que essa articulação ocorreria no plano dos discursos filosóficos. Fiz em seguida, ao longo do texto, várias considerações a respeito de algumas concepções na história da filosofia, em particular, na tradição do empirismo inglês, sobre o humanismo. Ao longo de toda essa trajetória tentei mostrar que há mais de uma forma de se pensar o humanismo. Procurei descrever, através da análise do conceito de racionalidade de 
Habermas e da teoria do poder de Foucault que a produção de conhecimento na medicina, assim como a utilização desse saber produzido na prática cotidiana, ocorre de uma forma que, na maioria das vezes, encobre a capacidade crítica de quem o está exercendo, e que, esse, é um dos motivos do por que a dimensão apenas técnica acaba por se sobrepor à dimensão humana da medicina. Em mais de uma ocasião defendi a posição de que a forma de pensar do médico é um determinante importante para tudo o que circula em torno da medicina, da arquitetura à prescrição de medicamentos. Tentei demonstrar que a forma como se pensa o problema clínico hoje em dia teve determinantes que não têm relações diretas com o problema clínico propriamente dito, que toda a metodologia científica contida na Epidemiologia Clínica se sedimentou como verdade atendendo interesses não relacionados nem com a tradição da epidemiologia nem da clínica. Tentei, finalmente, apontar para o fato de que havia também por detrás da ideologia técnicocientífica um certo senso de humanidade e que os objetivos de ambos os discursos, tanto os que atacam a racionalização técnico-científica, quando os que a defendem, como uma forma de tornar a medicina mais humana, poderiam tentar sentar para conversar de forma mais aberta, uma vez que no final das contas o objetivo de ambos é o mesmo.

Essa foi a trajetória. Acontece que isso, a bem dizer, é um pouco óbvio, e, como quase tudo que é obvio nem sempre é observado, ou valorizado adequadamente. Gostaria de tentar sugerir que qualquer tentativa de avançar no conceito de humanização em medicina deveria partir desse caráter óbvio de complementaridade de objetivos. E o que seria exatamente avançar nessa proposta de melhor entender a humanização em medicina? Isso é possível? Além das referidas práticas relacionadas às políticas públicas em curso, haverá outras formas de tentar entender e exercitar o conceito de uma medicina mais humana? Se sim como seria essa forma? Deixo para a conclusão dessa terceira parte minha opinião pessoal a esse respeito. 


\section{Análise Crítica sobre os textos de saúde coletiva que tratam da relação entre o método científico e a prática médica.}

\section{Relação método científico e prática clínica}

Vou procurar situar meus comentários em torno de temas polêmicos sobre metodologia científica em medicina e na relação deste assunto com uma crítica à epidemiologia clínica. Alguns comentários também vão ser feitos no sentido de tentar estimar a permeabilidade dessa polêmica no ambiente prático da clínica, fora dos departamentos de epidemiologia.

Parece-me que quem melhor explicitou a polêmica sobre o uso de métodos quantitativos em medicina recentemente foi o epidemiologista americano Alvin Feinstein, um dos fundadores intelectuais da Epidemiologia Clínica, que, em um artigo extremamente provocativo, alude ao fato de que os métodos empregados pela epidemiologia clássica deveriam ser abandonados em detrimento da nova técnica que ele propunha como forma de dirimir dúvidas relativas a problemas clínicos sobre a etiologia de doenças (Although some of the accusations have subsequently been refuted or withdrawn, they have usually been based on statistical associations in epidemiologic studies that could not be done with the costumary experimental methods in science (Feinstein, 1988)). Segundo este autor, a epidemiologia tradicional com sua metodologia observacional, pouco sujeita a controle, gera resultados necessariamente não conclusivos.

A reação da comunidade mundial de epidemiologistas foi violenta, ainda que não desproporcional. Não tenho conhecimento de repercussões deste episódio em outros ambientes médicos fora do círculo epidemiológico. $\mathrm{O}$ artigo original foi publicado na famosa revista Science, mas todas as respostas a que consegui ter acesso foram publicadas em revistas especializadas em epidemiologia (Savitz et al., 1990; 1991; Weiss, 1990). Considero no mínimo curioso o fato de que cientistas do meio clínico não se manifestaram contra, a 
favor, ou para tentar uma saída consensual para a polêmica. Mais curioso ainda é o fato de que, ao mesmo tempo em que se abriu um ponto de ruptura conceitual na epidemiologia, o meio clínico incorporou de forma avassaladora os métodos propostos por Feinstein em suas investigações. É inequívoco o fato de que, hoje em dia, qualquer revista médica, de qualquer especialidade nas áreas clínica, cirúrgica ou diagnóstica, privilegia a publicação de estudos experimentais controlados conforme descritos pela metodologia da epidemiologia clínica. Até uma interessante dobra dessa metodologia, denominada prosaicamente de "Medicina Baseada em Evidências", surgiu no cenário de decisão médica como a panacéia para questão da dúvida médica. $A$ última coisa que quero é passar a impressão de que não há motivos para o estabelecimento desse embate, isso seria contrariar o método de análise de discursos que empreendi. O que quero, a título de situar o objetivo do meu empreendimento no cenário científico atual, é chamar a atenção para o fato de que uma crítica à validade epistêmica do método proposto pela epidemiologia clínica restringiu-se, e ainda se restringe, ao mundo dos epidemiologistas. Suspeito que muito poucos médicos praticantes, ou mesmo formadores de opinião que exercem especialidades médicas, dedicam tempo para ler publicações especializadas em epidemiologia. Esses mesmos médicos que diagnosticam, tratam e prognosticam enfermidades, aceitam as verdades produzidas, incorporam-nas em seus cotidianos, e reproduzem-nas nos ambulatórios, consultórios, enfermarias e salas de ensino. Tudo isso normalmente de uma forma pouco crítica. Uma das intenções desse trabalho é exatamente tentar contribuir na construção dessa crítica.

A análise feita por Naomar de Almeida Filho em "A Clínica e a Epidemiologia" (Filho, 1997) de certa forma demonstra isso. O autor discorre sobre a história da ciência com enorme liberdade. De uma maneira extremamente pessoal, captura conceitos da filosofia e os interpreta de forma livre e poética. Texto de grande envergadura denunciativa e que deveria ser lido por todo médico praticante nos quatro cantos do mundo, sobretudo os recém-formados. Entretanto há alguns pontos que provocam um certo desconforto do ponto de vista analítico. Em primeiro lugar o método de análise histórica empregado. Apesar do autor, por uma espécie de "contra-preconceito", tentar se desfazer 
dessa crítica, ele é aparentemente idealista em sua essência. A definição de objeto da ciência ("objeto-modelo" na denominação do autor), o desenvolvimento desse conceito e a sua repetição infinitas vezes ao longo do texto sugere que talvez o autor esteja ancorado em uma tradição de produzir história sob a égide do Absoluto hegeliano. No capítulo final, quando lamenta o fato do homem contemporâneo estar perdendo sua subjetividade, nas palavras do autor "...o cyborg, homem pós-moderno ", e que o "conceito de risco como conceito fundante na sua fabricação enquanto figura mítica que se constitui historicamente nos tempos que correm" é uma espécie de amálgama dessa realidade, claramente o autor se coloca em um mundo com "defeitos" no qual uma redenção é necessária. Até esse ponto a argumentação é perfeitamente aceitável. Realmente é muito complicado sequer pensar em escapar dessa espécie de logocentrismo histórico, sobretudo no ambiente médico e acadêmico (eu mesmo não tenho certeza se de fato consegui fazê-lo), mas, o que realmente chama a atenção do ponto de vista das conclusões deste texto, é o fato de que a proposta de solução apontada vai se encaixar totalmente dentro do próprio paradigma que critica. Explicando melhor: partindo de uma hipótese, a meu ver questionável, de que a clínica tem uma natureza qualitativa e que a epidemiologia tem uma natureza quantitativa, e que, portanto, o objeto da epidemiologia deveria ser algo como intermediário entre os dois (“Conclusão: um objeto intermediário?"), o texto busca uma muito interessante aproximação com as ciências humanas, mas que culmina de maneira decepcionante com uma abordagem "holística-ecológica", o que seria uma espécie de instrumento ideal de análise da questão médica. Neste sentido, compreende-se a aproximação com a teoria do caos pela época em que a primeira edição foi escrita, mas o desvio para inteligência artificial na segunda edição (As noções de sistemas complexos e níveis hierarquizados, relacionadas com o desenvolvimento da inteligência artificial no contexto das novas abordagens epistemológicas, poderão superar as restrições interpretativas dos modelos dominantes da Epidemiologia contemporânea), desvelam definitivamente que o texto confunde paradigma com metodologia e que a solução apontada não consegue, apesar de genuinamente ter tentado, escapar do paradigma que critica. 
Esta é apenas uma análise superficial que o espaço me permite. Há muitos outros pontos que clamam por uma crítica. Julgo que uma crítica realmente consistente da Epidemiologia Clínica demanda instrumentos interpretativos mais rigorosos, além de um maior distanciamento prático e emocional, tanto da epidemiologia quanto da clínica. Há um ponto no trabalho, entretanto, que considero muito importante e que definitivamente incorporei em minha análise: trata-se da já referida aproximação da medicina científica com a história e os métodos discursivos das ciências humanas, cunhado pelo autor como "etnoepidemiologia".

$\mathrm{O}$ outro texto de que tentarei fazer uma resenha com o objetivo de situar melhor minha proposta dentro das discussões já produzidas é o trabalho intitulado "Biomedicina, Saber e Ciência: Uma Abordagem Crítica", do autor Kenneth Camargo Junior (2003). Há também neste texto um forte veio crítico chamando a atenção para o fato de que os médicos praticantes exercem a medicina de forma não crítica (A crença dos médicos na "cientificidade" de sua prática - e mais que isso, na eficácia dessa cientificidade - é, num certo sentido, mágica, já que a forma como os conhecimentos são produzidos thes escapa, fazendo que esses conhecimentos sejam incorporados a essa prática de forma acrítica). Já na apresentação o autor revela quem é e onde quer chegar. Ao se definir como um "construcionista reformista" demonstra seu inconformismo com a situação atual do que chama "biomedicina" e busca construir, através de um maravilhoso e juvenil otimismo, uma saída para o abuso da ciência como referencial de produção de verdade em medicina. Por ser uma coletânea de textos, de diversas épocas, sobre vários assuntos, e com várias metodologias de análise, julgo difícil (talvez pelo grande risco de acabar cometendo, não intencionalmente, uma injustiça fundamentada no erro interpretativo) descrever a linha de pensamento do autor, portanto vou descrever e tentar discutir alguns pontos que considero importantes para situar a intenção da minha proposta de trabalho no contexto da produção do autor.

De uma maneira geral me parece que a polêmica sobre a metodologia científica em medicina é situada de forma historicamente consistente em relação às fontes bibliográficas utilizadas e tem como conclusão: "O ocidente 
industrializado tem na ciência seu referencial último de verdade. A descrição científica define o real; segue-se, portanto, que a "verdadeira" medicina é verdadeiramente científica. Espero poder demonstrar ao longo dos capítulos seguintes que esse pressuposto não é inevitável, mas historicamente determinado e que esta concepção engendra em si uma série de problemas". É da mesma conclusão que parti e, mais ou menos no mesmo final que espero ter chegado. Contudo, certamente, usei outros métodos e argumentos. Há dois aspectos da obra do autor que quero chamar a atenção: o primeiro e mais importante, é a busca do referencial científico abandonando a "quimera científica". Nas palavras do autor: "Por paradoxal que possa parecer, abandonando a busca da quimera científica talvez possamos ser científicos como nunca fomos. Ter certeza, como a clínica supõe ter, é fatal às dúvidas, matriz da investigação científica". Talvez, por estar o autor ancorado fortemente nos ditames da metodologia científica, e do cogito cartesiano, ele não tenha percebido que foi partindo exatamente do mesmíssimo pressuposto que a Epidemiologia Clínica fundou suas bases (talvez, ao contrário, eu não o tenha entendido adequadamente). Curiosamente a crítica adquire um interessante aspecto circular e termina a meu ver no mesmo lugar, a saber: o primado da razão científica. A questão é: será que a razão científica dá conta da questão fundamental da medicina? Que nas palavras do próprio autor é "aliviar sofrimentos"? O segundo ponto que me chamou a atenção foi o mergulho na subjetividade como forma de contornar o que chama de "excesso de medicalização". Não consegui entender totalmente a que tipo de subjetividade $\mathrm{o}$ autor se refere, ancorado em que discurso ele está. A subjetividade é um reino por onde passearam e conviveram personalidades como Descartes, Kant, e Heiddeger, ou, a posição da primeira pessoa, o Eu? Arrisco dizer que é no Eu que o autor se situa, e, nesse caso, se for aí realmente onde se enraízam os argumentos, se for de uma espécie de psicologia científica a que o autor se refere, recorro ao líder em citações $G$. Canguilhem quando diz que a psicologia é "uma filosofia sem rigor, uma ética sem exigência e uma medicina sem controle" (Canguilhem, 1973). Digo isso, não para descredenciar a bela construção poética e científica do Prof. Kenneth Camargo, realmente não me julgo em condições técnicas para isso, mas, para argumentar que, tentar buscar a objetividade colocada em xeque no seio de um 
discurso que carece de fundamentos "objetiváveis", é uma estratégia que merece pelo menos algum grau de suspeição. Agora, se é ao reino da subjetividade como definido no mundo da filosofia que o autor se refere, então, neste caso, penso não haver limites para os problemas que se desenham à nossa frente e a possibilidade de críticas que estes podem gerar. Desconstruir o uso do método científico aplicado à medicina, e depois buscar reconstruir esse mesmo método na subjetividade do indivíduo, é uma contradição insolúvel. A subjetividade é o primado do método científico cartesiano. Ela já está presente em sua total plenitude na própria objetivação.

Como se diz no plano do senso-comum: Criticar é fácil, difícil é fazer! Impossível não pagar um enorme tributo às reflexões do Prof. Kenneth. Seu mergulho na subjetividade é um sinal de alerta. Um toque inesperado do despertador avisando de que é hora de levantar. O despertar de um "sono dogmático". Apenas acho que o mundo e a medicina talvez já estejam bem servidos de "psicologias", e que, há que se tentar entender a questão da hipertrofia da dimensão técnica da medicina através de outros instrumentos. Tenho a suspeita de que há outras formas de se ver a essência do pensamento médico sem ter que necessariamente que se valer de uma interrogação da consciência, de um escrutínio do ego. Talvez analisando outras racionalidades, como por exemplo, a da Medicina Oriental, consigamos nos dar conta de que nosso sistema atual de ver, analisar,concluir e agir sobre o "sofrimento humano" não seja a única forma de dar conta eficientemente desse mesmo sofrimento.

O trabalho de José Ricardo Ayres "Sobre o Risco - Para Compreender a Epidemiologia" (Ayres, 2002) também pode ser situado, embora através de uma retórica mais elaborada e hermética, no contexto da utilização prática da crítica aos fundamentos da metodologia científica aplicada à medicina. A questão parece se situar muito mais na relação da epidemiologia com a medicina social do que propriamente com as práticas de decisão médica individual, ou, tentando ser mais preciso: esta última adquire um caráter tributário do ponto de vista de análise em relação à primeira. De toda a forma a discussão é presente. Baseado em uma análise histórica impecável, de um 
rigor incomum em qualquer meio, cuja única ressalva que consigo pensar, apesar dela ter um caráter extremamente positivo por revelar uma originalidade do autor, é o porquê a magistral obra de Georges Canguilhem "La Formation du Concept de Reflexe" não é citada como modelo a seguir para a história da epidemiologia. Tendo como pano de fundo a construção do conceito de risco, a história da epidemiologia é visitada de forma didática e apaixonante. Minha referência à obra do Canguilhem tem um motivo simples, o autor assim como 0 famoso filósofo da ciência francês, identifica em algum lugar, fora dos cânones habituais, a origem dos conceitos estudados, risco e reflexo respectivamente. Canguilhem coloca em xeque a noção tradicional de que o conceito de reflexo, como atualmente utilizado pela neurologia, tenha sido elaborado por Descartes e a Teoria Mecânica do Movimento Involuntário, e, sustenta ter sido Willis, no final do século XIX quem de fato construiu o conceito conforme os atuais referenciais científicos. José Ricardo Ayres também encontra a origem do conceito de risco fora do lugar aparentemente óbvio, a medicina das doenças crônicas do pós-guerra, mas no espaço histórico que denominou de "Epidemiologia da exposição" e que precede aquela época em alguns anos. Todo esse cortejo de argumentos e esse arremedo de análise comparativa têm como objetivo situar minhas intenções de método de análise histórica com as do autor (assim como de Canguilhem e Foulcault) e voltar à questão da inserção no mundo da decisão médica. Ao contrário da busca de um objetoconceito há na metodologia empregada por José Ricardo Ayres a noção de que o objeto é apenas um correlato da prática.

José Ricardo Ayres transpira hermenêutica filosófica em cada parágrafo, em cada frase. Sua formidável análise histórica aponta para destinos que nem sempre são compreensíveis, e, para soluções pragmáticas que nem sempre guardam uma relação lógica interna com seus argumentos teóricos, ou dizendo de forma diferente, com sua postura teórica não idealizada. A idéia de um Transcendente paira sobre nossas mentes como um espectro a ser combatido, ou incorporado. Preciso a título de melhor explicar meus próprios argumentos me situar fora da crítica que fiz ao trabalho do Naomar Almeida Filho e seu idealismo que denominei de "ancorado ao Absoluto hegeliano". Na ligação que é feita entre a epidemiologia, sua história, e a formação do conceito de risco, 
um importante (e cheio de riscos) passo é dado no sentido de apontar para a influência desses discursos no conjunto das práticas sociais. Aqui dois pontos me chamaram a atenção: uma tendência a reservar para a epidemiologia um papel de destaque na correta condução deste processo, e, logo em seguida, a assertiva totalmente incluída na tradição humanista da "inexorável interdependência vivida por todos nós, criaturas/criadores de projetos necessariamente inconclusivos de tudo o que é humano ou relacionado ao humano. Não pode haver um projeto efetivamente humano, para a vida ou para a saúde, que desconheça ou desconsidere o projeto do outro". Julgo valer a pena uma interpretação de dois outros textos do autor para situar mais claramente a relação entre o objeto do trabalho que realizei e os discursos da Medicina Social.

A reflexão empreendida por Ayres em "Interpretação histórica e transformação científica: a tarefa hermenêutica de uma teoria crítica da epidemiologia" (Ayres, 1994) de que as ciências, de uma maneira geral, quando se defrontam com dificuldades empíricas ou conceituais em relação a sua consistência teórica, buscam resolver esses impasses epistemológicos num plano eminentemente formal, via de regra, valendo-se de uma atitude filosófica positivista, que, na verdade, estabelece limites muito restritos para a abordagem e solução do problema, por efetivamente restringir os seus argumentos às determinações internas do conhecimento, e que uma abordagem histórica das aporias e dificuldades dessa ciência poderia ser um caminho para uma reflexão mais aprofundada do problema, foi, verdadeiramente, um dos pontos de partida que foi adotado no trabalho que empreendi. Concordo com quase todas as assertivas dessa proposição, faço apenas uma pequena ressalva com relação à associação entre a formalização de respostas a impasses epistemológicos e a filosofia positivista. Definitivamente não penso que esse seja um atributo exclusivo do positivismo histórico. Muitas outras correntes de pensamento epistemológico se valeram dessa estratégia.

Segundo esse mesmo autor, no mesmo trabalho, em ciências de conteúdo empírico mais robusto, como é o caso da epidemiologia, o alcance desse método de análise crítica formal, conforme descrito no parágrafo anterior, 
restringe-se ao aumento do grau de positividade dos seus enunciados. Portanto, os resultados desses ajustes, não atingem, nessas ciências, o conteúdo de conceitos e métodos, mas apenas as condições de validade dessas inferências. A partir desse ponto, analisa-se a proposta de Miettinem de consolidação da cientificidade da epidemiologia através de uma evidente metonímia matemática, o que se entende por aprofundamento das reflexões internas da linguagem matemática da ciência epidemiológica.

Em contraposição a esse método, Ayres propõe a realização de uma análise de cunho histórico como forma de autocompreensão das entranhas da ciência epidemiológica e suas relações com a clínica. Sugere inicialmente uma reflexão ética fundada em contextos de práticas historicamente circunscritos. Refere-se finalmente à "filosofia da práxis" como um "dos mais expressivos desenvolvimentos realizados nessa direção pela racionalidade ocidental moderna". Ao proceder dessa forma, a razão incorpora um mecanismo de autoentendimento que a libera de qualquer aspiração universal e absoluta. Ela assume a si mesma como uma experiência de sujeitos datados e localizados, organizados socialmente com o objetivo satisfazer necessidades materiais ou não. Como conseqüência desse processo de análise, os impasses com os quais se defronta a epidemiologia contemporânea não se reduzem a problemas que têm que ser resolvidos, eles passam a se configurar como um devir histórico, como um substrato para uma contínua reconstrução do conhecimento.

Após uma breve revisão sobre a formação histórica do paradigma de risco em epidemiologia, promove uma interessante inflexão rumo à outra proposta de sistema de pensamento, por considerar o "paradigma da práxis" útil na medida em que consegue denunciar determinações sócio-históricas onde só parecia haver questões lógico-formais, mas, como limitado para penetrar na intimidade dessas determinações. Brilhante construção teórica rumo ao objetivo de defender a posição Habermasiana da "dialética das interações" como o objetivo de seu horizonte de reflexão epistemológica no terreno da epidemiologia. Nesse sentido, a prática científica da epidemiologia é entendida "como uma construção aparentemente una de contribuições necessariamente múltiplas de 
diversos sujeitos portadores de projetos e poderes diversos". A ciência passa a ser necessariamente investigada como um campo de complexas relações intersubjetivas, e essa posição desemboca novamente em Habermas e sua "Teoria do Agir Comunicativo".

Nessa perspectiva, a ciência epidemiológica passa a ser vista como uma estrutura lingüística de produção de certezas provisórias, nas quais os proferimentos não ganham estatuto de verdade científica em decorrência de uma aptidão universal do sujeito cognoscente ao conhecimento, tão pouco das condições imanentes dos objetos do conhecimento, mas da operacionalização efetiva deste conceito de verdade em um ambiente social onde o discurso científico ganha um status de operante, de funcional. A validade real do conhecimento científico é tributária da intersubjetividade que funda toda construção racional. O critério de verdade depende do formato e do grau de consenso que é possível obter-se em uma comunidade de seres falantes. Mas, o percurso rumo a outros destinos continua a nos envolver. $O$ autor, após essas reflexões sobre a epidemiologia como ciência, que, já seriam suficientes para nos deixar satisfeitos, nos apronta mais uma peça ao se referir e reivindicar à estética kantiana, o espaço de um artifício lógico para dizer que há nessa dimensão estética uma espécie de "duplo" da dimensão epistemológica da ciência, uma parte inexorável da sua realidade que é inatingível nos termos parciais em que os conceitos as representam. Exemplifica de forma magistral perguntando: "Como conceber que experiências como "sistemas de signos/significados", "valores positivos de saúde", ou "necessidades humanas" possam ser inteiramente recobertos por qualquer discurso objetivo? Como imaginar que a linguagem epidemiológica possa traduzir imediatamente a experiência vivida do adoecer coletivo? Impossível." Deriva daí uma nova inflexão, dessa vez rumo à "dialética das representações", o que significa, realizar um trabalho de natureza interpretativo que tenha como objetivo compreender a intersubjetividade realizada pela ciência. Pousamos no campo da hermenêutica e aqui vamos desembarcar.

Usando a autoridade de Gadamer, o autor circunscreve a necessidade de se fazer uma "analítica do sentido" uma discussão das relações intrínsecas entre 
ethos e linguagem. Nesse ponto, penso, está a questão mais importante do trabalho e uma das idéias em cima da quais procurei empreender toda uma linha argumentativa para a justificativa do meu trabalho na área de saúde coletiva. Pretendo discorrer um pouco mais sobre o que essa questão determina no discurso, nas praticas e nas políticas de saúde. Para ficar no lado seguro da interpretação, procurarei a partir de agora buscar apoio nas frases escritas pelo próprio autor para definir melhor o que ele entende por uma "hermenêutica profunda do discurso epidemiológico não para resgatar a totalidade das vontades de saúde interditadas na trajetória da construção do discurso epidemiológico, mas sim para identificar nos movimentos históricos dessa interdição o seu sentido opressor, e superá-lo". Prossegue o autor:

"O leitmotiv da obra de Gadamer é a superação da dicotomia sujeito-objeto na compreensão dos fatos e obras humanos. Olhar a linguagem "de fora" considerar aspectos extralingüísticos de sua determinação, seria pretender um distanciamento metodológico que comprometeria a historicidade da compreensão. Aquilo que para concepções positivistas do fato humano constitui um vício e um obstáculo - o círculo lógico em que se vê a compreensão, uma vez que quem compreende está incluído no que quer compreender - para Gadamer, ao contrário, constitui a essência mesma do compreender. A coincidência entre conhecedor e conhecido é o que, desde Dilthey, é visto como uma garantia de acesso do pensamento à experiência que excede a objetividade. É a totalidade vivida que, como pano de fundo, faz distinguir a forma particular do fenômeno humano, configurando o "círculo hermenêutico". Só a experiência da pertença em relação a tudo que é humano permite compreender o fato ou as obras particulares, distinguir as experiências pretéritas e alheias das próprias, identificar a um só tempo, o si mesmo e o Outro." O texto continua: "Gadamer em sua recusa de distanciamento da linguagem, encara esse acesso ao Outro não como um resgate de seu horizonte e sim como uma "fusão de horizontes"'”.

Trata-se de um artigo que faz pensar. Na verdade o texto chega a provocar, a exigir uma reflexão e uma resposta a sua altura. A utilização da história como instrumento de argumentação é relativamente fácil de entender, mas algo nos 
empurra para uma reflexão mais profunda acerca das intenções do autor. Onde esse assunto se liga com a prática médica? O que exatamente essas interessantes reflexões sobre hermenêutica de fato contribuem para a compreensão da epistemologia médica tendo como índice a epidemiologia? Aonde afinal ele quer chegar?

Respondo em duas frases: humanização da saúde! O autor é um humanista.

Toda a argumentação gira em torno de se construir um arcabouço de inteligibilidade cujo objetivo é propor um método de resolução para uma prática médica inexoravelmente imersa em um sistema predominantemente instrumental e que está totalmente enraizada em uma operacionalização tecnicista. A idéia parece ser mostrar que, nessa forma de prática médica, 0 conceito e a autocrítica de seus métodos de teorização e de ação circulam apenas em torno de seus próprios construtos teóricos e seus resultados operacionais, e que, nesse jogo de espelhos, o Homem não tem mais papel de destaque. Busca-se uma forma de retornar ao Homem seu papel de protagonista na história da Medicina.

De fato, a distância que a tecnologia impôs ao Homem em sua relação com o mundo que o cerca terminou por construir uma situação na qual, para se falar algo que deveria ser evidente, ou seja, que a medicina é uma prática cujos marcos inicial e final têm que necessariamente ser o Ser Humano, acaba sendo preciso muitas vezes percorrer percursos longos e tortuosos.

Por último, vamos tentar empreender uma breve análise de outro trabalho do Prof. Ayres, intitulado "Para comprender el sentido práctico de las acciones de salud: contribuciones de la Hermenéutica Filosófica" (Ayres, 2008). A análise desse texto visa dois objetivos principais. Primeiramente, ajudar a entender melhor, o que exatamente uma crítica ao que chamei o "novo saber médico" sob uma perspectiva histórica, e usando a questão dos registros de novas drogas, pode remotamente agregar a uma discussão na área de Saúde Pública. Em segundo lugar, porque o texto aponta para soluções ou 
perspectivas relacionadas à prática médica que são particularmente interessantes, e que remetem aos meus comentários finais dessa tese.

Lê-se nesse trabalho o seguinte trecho:

Ocurre que la dimensión práxica (f) de las acciones de salud es frecuentemente explorada en reflexiones críticas externas a su tecnicalidad, o sea, los supuestos e implicancias prácticos de las acciones de salud son abordados deforma negadora, identificándose racionalmente consecuencias negativamente valorizadas de una técnica, pero no las relaciones entre la propia técnica y esos valores. Más allá de esto, las reflexiones prácticas son, también con mucha frecuencia, aprehendidas en el ámbito de totalidades sociohistóricas macroscópicas, muchas veces en el marco de un proceso civilizador como un todo, o de conformaciones culturales, institucionales $\mathrm{y} / \mathrm{o}$ económicas de toda una sociedad, y no en el plano microscópico de la operación de las tecnologías. Estas construcciones críticas han sido relevantes en la discusión de políticas, en reorganizaciones institucionales y hasta en la reestructuración de modelos asistenciales. Sin embargo no hacen prescindibles a los intentos de comprender supuestos e implicancias prácticas en el ámbito más estricto de situaciones particulares de práctica, tales como una consulta médica, una consulta psicoterapéutica, un grupo educativo, una acción comunitaria, un programa de salud.

Conocemos bastante de los fundamentos e implicancias sociales de la medicina occidental contemporánea, pero, ¿tendremos esta misma seguridad si nos preguntaran, por ejemplo, sobre fundamentos e implicancias de la atención en salud que acabamos de realizar? Sabemos que no podemos transponer esos diferentes planos de comprensión sin cuidadosas y complejas mediaciones. Otro aspecto a ser considerado es que, si no queremos quedarnos solo en el momento negador del proceso crítico, si queremos proponer positivamente alternativas, debemos tener recursos para comprender y transformar las acciones de salud desde esa base técnica que las justifica y reproduce como práctica social e histórica, o sea, su sentido práctico necesita ser conocido y tematizado en los procesos mismos en que se actualizan como tecnologías, en que se realiza su instrumentalidad.

Deriva dessa análise a conclusão extremamente interessante de que o sucesso do cuidado em saúde depende da "fusão dos horizontes" de duas dimensões constituintes da prática médica: o êxito técnico e o logro prático. O autor afirma logo na introdução que a as práticas de saúde contemporâneas já apresentam poderosos meios para garantir seu êxito instrumental, mas que carecem de uma base conceitual robusta para uma adequada compreensão e transformação do sentido prático dos processos de saúde-enfermidade- 
cuidado. Em seguida aponta de forma extremamente competente para a utilização da hermenêutica filosófica como uma forma de tentar superar essa dificuldade.

A análise que fiz a respeito da história dos registros de novos medicamentos nos Estados Unidos, deve ser vista como uma forma de procurar entender melhor a primeira das proposições desse texto. A idéia é mostrar que os instrumentos que asseguram o chamado êxito técnico não são assim tão poderosos, eles também têm sua história. Isso está dito no texto e assegurado como óbvio, mas, mais importante que isso, é o fato de que o conhecimento dessa história ajuda não só na construção de modelos assistenciais ou na discussão de políticas públicas de saúde, mas, que eles podem também ajudar numa autocrítica por parte dos profissionais de saúde em situações práticas muito particulares, como uma consulta médica, uma ação comunitária ou um programa de saúde. Entender que a forma como se pensa a questão chamada de "instrumental" sob uma ótica que não é apenas uma discussão da validade epistemológica das verdades proferidas pelo método científico, ou de suas injunções econômicas e sociais, mas, e, sobretudo sob a perspectiva de que ambas essas dimensões estão inexoravelmente juntas e compõem um continuo, é, na minha visão, se aproximar mais intensamente da busca de uma mais adequada compreensão e transformação do sentido prático dos processos de saúde-enfermidade-cuidado. É tentar caminhar mais solidamente rumo a almejada fusão dos horizontes que o autor busca. A diferença é que, ao invés de propor logo em primeira instância, uma solução via resgate dialógico, (registre-se o fato de que concordo plenamente com o autor e considero realmente como sendo essa a melhor solução possível para toda essa questão, só não tenho, ainda, a menor idéia de como se deve fazer isso), alternativamente estou propondo que, antes desse passo, ou talvez mais apropriadamente junto a ele, reflita-se melhor sobre os fundamentos históricos da própria dimensão técnica. Sobre como se produz e como se utiliza a verdade na prática médica contemporânea. Sobre como nós na vida prática pensamos o problema clínico. Sobre como temos dificuldade, devido a barreiras externas e internas, de promover uma verdadeira autocrítica sobre essa forma de pensar e agir. Minha proposta é justamente tentar: "comprender 
y transformar las acciones de salud desde esa base técnica que las justifica y reproduce como práctica social e histórica, o sea, su sentido práctico necesita ser conocido y tematizado en los procesos mismos en que se actualizan como tecnologías, en que se realiza su instrumentalizad ". Para isso, penso, há que tentar se esgotar a reflexão sobre a técnica.

O convite a essa reflexão prévia (ou conjunta) tem o valor simbólico de um antepasto. Estou consciente de que não é a refeição principal. Trata-se de uma contribuição apenas marginal. Realmente penso que novos caminhos têm que ser trilhados. A coragem do Prof. Ayres nesse tipo de empreendimento é verdadeiramente aristotélica. Percebe-se a busca por uma virtude individual. É uma atividade ética. A articulação que procura fazer entre a ontologia de Heidegger e a prática médica, mesmo sob os auspícios luxuosos do pensamento claro e profundo de Gadamer, é verdadeiramente surpreendente. Nos últimos parágrafos dessa tese vou tentar descrever minha visão pessoal dessa empreitada intelectual, que, na realidade, não me julgo ainda em condições de realizar, muito menos de criticar. Destaco nesse momento apenas o fato de que o percurso que o Prof. Ayres está caminhando é extremamente pedregoso e cheio de armadilhas. Tenho absoluta certeza de que ele é consciente disso, daí minha admiração por sua coragem.

\section{A questão da humanização e sua relação com o objeto desse trabalho}

Uma análise histórica dos discursos proferidos a respeito da humanização em saúde no Brasil, desde a década de 50 até os nossos dias, revela alguns interessantes fatos: Primeiramente a constatação, com freqüentes menções, de que a racionalização, a mecanização e a burocratização excessivas do atendimento aos pacientes impedem que o profissional de saúde desenvolva sua capacidade crítico-criativa e que, esse processo produtivo instituído dessa forma, tem conseqüências desumanizantes, ao dar ênfase à realização de tarefas de forma fragmentada e não construindo condições para que os pacientes sejam vistos em uma dimensão holística. O paciente individualizado, com seus problemas, temores e necessidades não é levado em conta. Portanto 
o que essa literatura chama de humanização emerge como uma necessidade em um contexto de uma medicina exclusivamente técnica (Benevides, 2005 b; Fortes, 2004; Reis, 2004). Outro aspecto que emana da análise desses textos é a evolução da concepção prática do que deve ser considerado como um processo de humanização. Nos artigos mais remotos, a questão caritativa do atendimento ganha destaque, aborda-se particularmente os pontos relacionados à relação interpessoal com os pacientes. Logo em seguida, questões relativas a técnicas administrativas, condições de trabalho dos profissionais, e até arquitetura do ambiente institucional, passaram a conviver com as questões interpessoais como aspecto relevante (Casate J.C, 2005). Contudo, a partir do final da década de 90 uma nova e interessante inflexão ocorreu. Os textos, a partir dessa época, começam a priorizar a atitude de humanização em saúde em uma perspectiva de um projeto político, que deveria ser o direito de todos os cidadãos e que deveria ser garantido pelo Estado. Muito resumidamente, pode se dizer que essa abordagem culminou na construção pela própria máquina do Estado Brasileiro de uma "Política Nacional de Humanização da atenção e da gestão na saúde"(PNH) (Benevides a, R. 2005).

Considero esse assunto extremamente relevante. Certamente avanços continuam permanentemente sendo propostos para a noção de humanização em saúde. Não há dúvidas de que a posição adotada por Ayres, descrita acima, representa um passo adicional em toda essa discussão, na medida em que faz confluir para a mesma operação pragmática do atendimento em saúde tanto a questão intersubjetiva quanto a questão das políticas públicas. Trata-se de uma proposta que, apesar de ser articulada em uma retórica que parece ser apenas de natureza teórica, abre espaço para uma verdadeira ampliação dos limites práticos da humanização em saúde. A maioria dos pressupostos teóricos que essa abordagem traz, quando bem compreendidos, conduzem a discussão para fora do subjetivismo caritativo e da burocracia administrativa do Estado, e usa, ambas essas visões de humanismo, como constituintes necessários para uma verdadeira humanização pragmática que é o que o autor chama de "fusão de horizontes". 
É nesse contexto, na tentativa de agregar informações de natureza histórica e epistemológica, abordando como se deu a formação da noção de causalidade, conforme a entendemos e operacionalizamos hoje em dia na prática clínica, usando como índice a análise da história do registro de novos medicamentos nos Estados Unidos a partir da década de sessenta, que empreendemos esse trabalho. A idéia é trazer argumentos adicionais para que o conceito de humanização em saúde possa ser ampliado. Por uma questão eminentemente metodológica, ousei penetrar na mente e nos métodos, não dos que normalmente se consideram ou são considerados pela nossa tradição como humanistas em nosso meio, mas, ao contrário, busquei entender o que a racionalização, a mecanização e a burocratização do atendimento aos pacientes, têm de positivo. Descrever sua humanidade.

\section{A história do humanismo}

Para isso apelo para a narrativa de uma breve história. Pessoalmente, considero a mais verdadeira de todas que pretendo contar, apesar de, infelizmente, todos documentos terem se perdido no tempo, o que pode dar a impressão de ser apenas uma fábula. Trata-se da história do humanismo!

A fonte dessa história é um filósofo búlgaro, mas que tem quase toda sua produção intelectual ligada à tradição estruturalista francesa. Seu nome é Tzevtan Todorov e seu principal foco de interesse é a literatura universal. Sua principal contribuição ao mundo das idéias foi trabalhar o conceito de "fantástico" em literatura. Segundo ele, fantástico são coisas que acontecem na nossa vida e que nos parecem ter uma natureza supra-mundana, cabendo aos homens, diante da ocorrência de um evento fantástico, decidir se ele é apenas uma ilusão, se é real, ou se é super natural. A partir daí constitui-se uma verdadeira ontologia que, por motivos óbvios, não cabe aqui descrever. Vamos à verdadeira história do humanismo, conforme descrita por Todorov na obra "O Jardim Imperfeito" (Todorov, 2006). Em momentos anteriores, quando discorri sobre as barreiras a uma verdadeira livre competição baseada em preços na 
área de medicamentos, já usei esse exótico tipo de narrativa com objetivo de tentar ser mais didático.

Há na história da humanidade três momentos que caracterizam bem a relação entre o homem e o diabo. O primeiro remonta ao tempo de Jesus Cristo, que, após jejuar por quarenta dias no deserto, foi abordado por Satanás, que the prometeu, então, adquirir o poder sobre todos os reinos da terra, desde que Jesus o reconhecesse como mestre. Jesus, como todos sabem, recusou o pacto alegando que não estava interessado naquele poder, que queria apenas servir a Deus, e que o reino em que estava interessado definitivamente não pertencia a esse mundo. Apesar da recusa de Jesus, seus seguidores durante mais de catorze séculos, do Imperador Romano Constantino até o Rei Francês Luis $\mathrm{XVI}$, acataram as condições do diabo e reinaram sobre suas propriedades com todas as prerrogativas de usufruto do poder que este lhes deu sem nunca terem deixado de reverenciá-lo como seu Senhor.

O segundo momento aconteceu no século XV quando Mefistófeles procurou um homem extremamente ambicioso, um necromântico e prestidigitador chamado Fausto, que tentava há muitos anos penetrar nos segredos da vida e da morte. Disse-lhe o envido do mal: terás acesso a todo o saber do mundo, nenhum enigma resistirá a ti, não ignoras com certeza que o saber conduz ao poder, portanto, terás também todo o meu poder, mas, em troca, peço-te apenas uma coisa, não quero de você nenhuma declaração, quero que, ao cabo de vinte e quatro anos, tu passes a me pertencer inteiramente, de corpo e alma. Diferentemente de Jesus, Fausto aceitou o pacto, e, durante muitos anos desfrutou de um saber infinito tendo sido cercado pela admiração de todos. Nos últimos anos do pacto, contudo, Fausto começou a ficar entediado, não ligava mais para nada, não queria mais penetrar em nenhum segredo oculto, não ligava mais para reinar sobre os homens. Tudo que queria era que o diabo esquecesse do pacto que haviam feito anos antes. Mas o diabo não esqueceu, e, ao final de vinte e quatro anos voltou a procurá-lo exigindo que a promessa fosse cumprida. Desse momento tudo o que se registrou Foram os grito de pavor que Fausto inutilmente lançava no ar. Teve que entregar-se ao Mal. 
O terceiro momento aconteceu logo depois. Dessa vez o diabo foi mais sutil e esperto. Sua astúcia consistiu em deixar que a parte contratante, o homem moderno, ignorasse a existência do contrato, deixá-lo acreditar que as vantagens que obtinha eram decorrentes de seus próprios esforços pessoais, e que não teria jamais que pagar nada a ninguém. $A$ oferta do diabo nesse pacto também foi diferente, foi mais intensa. Ele ofereceu ao homem a capacidade ilimitada de querer. $O$ homem moderno teria a capacidade de querer livremente, de adquirir o domínio sobre sua própria vontade e de levar a vida a sua maneira. $O$ detalhe desse pacto é que o diabo ocultava no contrato o preço da liberdade, este só seria revelado depois que o homem tomasse gosto por ela, ficasse dependente dela, e não mais quisesse renunciar-lhe. Nesse momento viria a exigência de quitação da dívida.

Livre para querer, o homem moderno tratou de desfrutar dessa benesse. Primeiramente assegurou que levaria sua vida pessoal de acordo com seus gostos, viveria junto aos seres pelos quais sentisse afeto, ao invés de seguir as leis do sangue ou da cidade, procuraria morar nas terras que melhor the conviesse, ao invés de ter que ficar preso a um determinado local, fosse por que motivo fosse. A restrição do usufruto da liberdade pelos sentimentos parecia muito pouco ambiciosa, limitada em sua potencialidade. $O$ segundo passo então, depois de reconhecer a liberdade de querer, foi exigir a libertação da razão. O homem não queria mais ter que reconhecer a autoridade da tradição conduzida pela memória dos homens. A razão tinha que ser livre para poder constatar e diferenciar o verdadeiro do falso. Só era então declarado certo o saber ao qual se chegara pelas luzes naturais da razão. Foi assim que nasceu a ciência puramente humana que é essencialmente diferente da onisciência descrita pelo Dr. Fausto. Após ter mergulhado nessas duas liberdades, as de se submeter apenas a suas próprias afeições e a sua própria razão, e ter tomado gosto pela liberdade de querer, o homem moderno resolveu, então, que tinha que dar um passo adiante: tinha que assumir o vasto domínio de suas ações públicas. Somente seria declarado moral uma ação que fosse realizada com liberdade e pela força da vontade individual; somente seria declarado legítimo um regime político que fosse escolhido pela vontade livre dos participantes do espaço público. Somente a democracia seria ética e 
moralmente legitimada. Portanto, na esfera dos sentimentos, da razão e do coletivo, o homem passou a querer, a exercer sua vontade. Ai começa nossa história.

Como havia sido dito, o valor do contrato não fora revelado. Após mais ou menos o período da Revolução Francesa, o Diabo, ao ver que o homem desfrutava de suas liberdades de forma totalmente natural, como se sempre as tivesse tido, como se estas Ihe pertencessem em sua própria natureza, na sua essência, enviou então à terra vários de seus seguidores, seus profetas, e estes escancararam o contrato na porta da humanidade. Vocês me devem, disse o demônio na voz e nos textos de seus enviados. Se quiserem continuar a desfrutar da liberdade terão de saldar um triplo débito: terão de se separar de seu Deus, terão de renunciar ao teu próximo e finalmente terão de renunciar si mesmos. Nada de Deus, serão apenas materialistas. Nada de Outros, serão apenas individualistas. Nada de $\mathrm{Si}$, seus egos serão apenas uma dispersão heteróclita de pulsões, uma dispersão que tende ao infinito, não merecerão mais a alcunha de "Sujeito". Assim mandou dizer o Diabo!

Diante dessa situação a humanidade ficou inteiramente perplexa. O que fazer agora? Houve, e ainda há, muita discussão a esse respeito. Desde a revelação do contrato todos aqueles que se dão ao trabalho de emitir suas opiniões em público, estudiosos, cientistas, filósofos, políticos e professores e doutorandos de medicina, se dividem inexoravelmente em alguns grupos que concentram opiniões e representam respostas que se procuram dar ao diabo. Esses grupos nunca conseguiram construir um consenso. Ainda hoje lutam por isso. Devidos a cruzamentos, defecções e adoções (dizem que por obra do Diabo), nem sempre os limites entre esses grupos são totalmente claros, mas para tentar ser didático e chegar no ponto do nosso assunto principal, vale a pena uma breve descrição de cada uma dessas posições. São quatro as possíveis respostas ao Diabo:

O primeiro grupo, que é o mais facilmente identificável, reúne os que pensam que o Diabo simplesmente tem razão, que trato é trato, mas que o preço da liberdade é alto demais. Renunciar a Deus, ao Próximo e ao Ego, é tarefa 
inatingível, portanto propõem um novo acordo, e, esse acordo é voltar ao estado anterior. Renunciar simplesmente a qualquer intenção de liberdade individual. Não vale a pena! Essa família é a dos conservadores. Os que desejariam viver num mundo cujos únicos valores são as tradições e as verdades cristalizadas. Os três outros grupos se confundem um pouco entre si, mas, ainda assim guardam características individuais que merecem uma descrição.

O segundo é o grupo dos cientistas. Estes, ao ouvirem as pretensões do diabo, rejeitaram-na sem pestanejar e sem nenhum medo. Não se preocupem, dizem eles para o palco da humanidade, não há verdadeiramente nenhum preço a pagar uma vez que, em verdade, nunca houve de fato nenhuma liberdade, a única liberdade que existe e sempre existirá, é a liberdade do saber. Graças às capacidades humanas de observação e raciocínio, graças, portanto, às ciências puramente humanas, é possível perscrutar todos os segredos da natureza e da história. No mais, quanto ao querer, a liberdade do homem, segundo os cientistas é, via de regra, bastante limitada, restringe-se à liberdade de conhecer. Os homens são conduzidos, à sua revelia, por leis físicas, biológicas e históricas. O que os homens têm tomado por liberdade é na verdade apenas ignorância. Portanto, nada há a lamentar, o diabo pode voltar para o inferno de mãos vazias que nada acontecerá com a humanidade.

O terceiro é o grupo dos individualistas. Estes têm uma resposta muito interessante a dar para o Diabo e para a humanidade. Dizem eles: os senhores acham que a perda de Deus, da Sociedade e do Ego nos impõem alguma restrição? Os senhores realmente acham que isso para nós é uma punição, uma penalidade por não cumprir um contrato que no mais, sequer reconhecemos? Pois fiquem sabendo que para nós isso representa uma verdadeira e desejada libertação. Queremos que o homem se afirme em sua solidão essencial, em sua liberdade de todo tipo de constrangimento moral, em sua dispersão ilimitada. Que ele afirme sempre e mais sua vontade de poder. Que sirva apenas a seu próprio interesse, pois daí advirá o verdadeiro bem. 
Finalmente, o quarto e último grupo é o dos humanistas! Estes ao contrário de todos os outros, pensam que a liberdade do homem de fato existe e que ela é preciosa, mas, apreciam também, ao mesmo tempo, os valores que são partilhados, a vida com os outros homens, e o ego que consideram com responsável por seus atos. De uma maneira geral querem continuar a desfrutar de todas as benesses da liberdade, porém, se recusam a pagar o preço que o diabo está cobrando. Os humanistas levam muito a sério as ameaças do diabo, entretanto, não reconhecem a legitimidade das cláusulas do acordo que este vem cobrar. Com peito aberto estampam na mesa de negociação o argumento de que o diabo fraudou e agiu de forma desonesta com a humanidade no momento da assinatura do contrato. Os humanistas lançam então ao diabo e a toda humanidade um desafio: não haverá conseqüência alguma se assumirmos de agora em diante, e para todo o sempre, que o homem é o ponto de partida e o ponto de chegada de todas as ações humanas. Tudo o que se fizer, pensar, e falar, deverá ter o homem como referencial. A especificidade dos negócios humanos, em contraposição aos que se referem a Deus, sobre Quem os humanistas se dividem em relação a seu estatuto ontológico, está no ponto de partida da doutrina humanista. Mesmo que não se reduza a ela, e mesmo que isso não signifique uma estima incondicional às ações humanas, os humanistas se julgam, através da coerência ética de seus pensamentos e da objetividade dos seus atos morais, superiores ao diabo.

A questões que devem ser colocadas nos dias de hoje são: o que é ser um humanista? Como praticar o humanismo num cotidiano no qual as regras da ciência e o conseqüente fetiche do domínio irrestrito sobre natureza fazem com que cada vez mais nos afastemos da humanitas do homo humanus? Como praticar uma medicina humana no contexto de um predomínio absoluto de uma racionalidade instrumental? Como escapar desse positivismo anacrônico e ineficaz? Será que há respostas para essas interrogações? 


\section{Caminhos a percorrer}

Essa incursão pelo humanismo, esse apelo a uma reflexão sobre o que se quer dizer com humanização da medicina, essa discussão que, reconheço, parece às vezes um pouco fora de contexto, que parece poder ser suprimida sem prejuízo do conteúdo geral da tese. Esse grito cego e solitário tem uma motivação pessoal, tem um fundamento existencial. A descrição de um conceito de humanismo proveniente da tradição anglo-saxã, e o seu reflexo no conceito mais utilizado em nosso meio, que emana principalmente da metafísica continental, em particular no, caso da discussão filosófica do campo da saúde, do idealismo alemão, não tem absolutamente o objetivo de tomar 0 partido de um em detrimento do outro. Não é isso que estou defendendo. Martin Heidegger, em seu polêmico trabalho sobre Nietzche, já havia dito que qualquer pessoa que se aproxime de um "pensar filosófico", mesmo que discordando dele, mas sem reconhecer seu potencial criador, sequer chegou perto de entender esse pensamento. É nessa perspectiva que apelo para uma reflexão mais intensa e crítica do que se quer dizer com humanização da medicina. Em mais de uma ocasião tentei defender a tese de que há mais de uma forma de se entender o que é a humanização da medicina. Por questões históricas e de tradição cultural, essa expressão tende a se aproximar de apenas uma dessas formas, produzindo uma maniqueísta e prejudicial polarização entre ciência e tecnologia de um lado, e humanismo e valor, do outro. O que fiz até aqui foi me aventurar na quase impossível tarefa de colocar em evidência que é possível tentar romper com esse círculo vicioso que faz com que uma discussão que me parece ser tão importante para a prática médica se torne insossa e infértil. Um diálogo que em geral só interessa a quem já sabe o que ele tem a dizer. Um quase-monólogo.

Penso, sem realmente querer ofender ninguém, que afirmar para a nossa medicina o mote de que os pacientes têm que ser ouvidos pelos profissionais de saúde é apenas uma tautologia. Por mais que esta seja necessária em virtude até mesmo da polarização hegemônica da chamada dimensão tecnocientífica e da ausência de crítica a esse processo, que defendi nesse 
trabalho, parar nesse ponto é a meu ver, repetir com outras palavras, o que se pretende demonstrar. É proferir uma proposição que tem por sujeito e predicado um mesmo conceito. Há que se tentar avançar nessa investigação. Há que se tentar propor novas investidas conceituais. Indubitavelmente a hermenêutica filosófica descrita nos parágrafos precedentes é uma saída promissora. Trata-se de um caminho ainda muito pouco explorado e que provavelmente vai gerar muitos frutos futuros.

A investigação que fiz tem a ambição de abrir caminhos rumo à colheita futura de alguns desses frutos. A investigação-denúncia de que o que aclamamos como ciência clínica tem determinantes outros que não apenas as necessidades práticas da clínica visa descortinar, ainda que em apenas um de seus aspectos, a forma de pensar da medicina contemporânea. Melhor dizendo, serve para ajudar a refletir sobre como pensamos quando temos que resolver um problema prático relacionado às demandas dos pacientes. Esse é só um primeiro e pequeno passo. Outros podem e devem ser tentados.

Defendo ainda que toda e qualquer reflexão que efetuemos a esse respeito não é quase nada em comparação com a experiência de viver sob uma racionalidade diferente da nossa. A Medicina Ocidental, apesar de poderosa e hegemônica, não é a única forma eficaz de se lidar com os problemas da clínica. Outras culturas, igualmente orgulhosas e ciosas de suas realizações, aguardam para serem ouvidas em suas maneiras de lidar com o sofrimento, a doença e a morte. Outras formas de ouvir, olhar, tocar, e interpretar as doenças merecem ser investigadas. A questão que se coloca aqui é como fazer isso? Que instrumentos interpretativos poderiam nos fazer escapar de mais um círculo vicioso? Como ver o "Homem Doente" de uma forma diferente da que a nossa ciência já vê? (A essa altura deve ser claro que não me sinto satisfeito com as respostas dadas pela psicologia, antropologia ou outras ciências ditas humanas para o contexto dos problemas relacionados à clínica). Penso ser possível tentar investigar outras racionalidades que se propõem a pensar os problemas da medicina assistencial prática, mas, para isso, primeiro temos que tentar nos libertar de algumas formas de "pensar" que estão como que encravadas em nossa relação com o mundo. Contudo, penso também ser 
preciso, para se aventurar nessa empreitada um outro e diferente gabarito de inteligibilidade, uma outra forma de ouvir, ver e tocar. Uma outra forma, que ainda não mencionei, de entender o humanismo. Vamos a ela.

Em 1927 foi publicada uma obra que mudou a história do humanismo na perspectiva em que até aqui descrevi, ou seja, no plano do pensamento filosófico. Nesse ano o filósofo alemão Martin Heidegger, após alguns anos de intensa reflexão e imersão no mundo da fenomenologia de Edmund Husserl (o mesmo que estava por detrás dos juristas que serviram como suporte intelectual do neoliberalismo alemão), publicou sua obra maior: Ser e Tempo (Heidegger, 2005). Na introdução, e em outras passagens procurei demonstrar a variabilidade dos conceitos de humanismo, a relatividade da concepção do que é o Ser Humano. Heidegger, a partir de Ser e Tempo, dá um salto olímpico em toda essa história. Através de uma crítica profunda a toda a tradição filosófica que o precedeu, coloca de cabeça para baixo todas as noções de humanismo, posto que, segundo ele, essa tradição fora fundada sob concepções equivocadas do que é o Homem. A questão de Heidegger era entender o que é o Ser, e, para fazer isso, ele apela para uma inacreditavelmente interessante, apesar de difícil, lógica discursiva, oriunda de uma certa tradição filosófica que ele certamente admirava, e que diz mais ou menos que, antes de se entender o que é o Ser, há que se entender as condições que permitem se fazer a pergunta sobre o que é o Ser. Para realizar esse empreendimento, Heidegger cria uma figura, reinventa um nome, nome esse que só faz algum sentido, em sua própria língua, o alemão. Esse nome é "dasein". Em português seria algo como: "ser ai", ou "presença". Pode-se dizer que Ser e Tempo é uma fenomenologia à moda husserliana do que é o dasein. Talvez um pouco mais, talvez uma superação do método fenomenológico.

Não pretendo, nesse trabalho (reservo essa ambição para um desenvolvimento futuro), promover uma reflexão sobre a ontologia heideggeriana, o que quero nesse momento, é através de uma leitura bastante superficial, apontar para o fato de que, ao fazer uma fenomenologia do dasein, Heidegger estava tentando entender melhor o que exatamente é Ser Humano. Ele jamais usaria esse termo, pois, para ele, o próprio conceito de Ser Humano era já enganador, e 
para que ele fosse mais bem compreendido haveria que tentar entender como de fato é a presença do homem no mundo que o cerca. Em poucas palavras, e aqui, ao contrário do seu mestre Husserl, um cartesiano, Heidegger propõe, para entender essa presença, o abandono de qualquer interrogação que seja mediada pela consciência. Seu pensamento, para tentar simplificar e se aproximar de algo que é extremamente complicado de entender, é uma espécie de anti-cartesianismo.

Repito que não vou tentar empreender toda uma descrição da obra de $\mathrm{M}$. Heidegger. Ainda não tenho condições para isso. Entretanto há um ponto que quero superficialmente abordar a fim de concluir esse trabalho, além de tentar contribuir para possíveis caminhos de desenvolvimento futuro que tenham o objetivo de repensar a dimensão humana da medicina. Heidegger diz que a relação primordial do homem com o mundo não é uma relação teórica. Ele quer dizer que, ao se deparar com um fato qualquer da vida, o homem não se coloca na posição de entender esse fato, de construir teorias sobre esses fatos. Isso para ele é secundário. Ao se deparar com situações práticas, o homem tenta descobrir o que se lhe apresenta aos sentidos e à sua cognição, não através de raciocínios inferenciais ou dedutivos, mas, através de um sistema de interpretação, de um sistema que se poderia chamar, usando expressão do próprio Heidegger, de hermenêutica. Essa é uma palavra que tem enorme significado em toda filosofia contemporânea, e que, assim como a noção de humanismo, pode ter diferentes significados em diferentes autores (mesmo para discípulos de Heidegger).Também não vou aprofundar essa questão. Para Heidegger, o conceito de hermenêutica, a noção de que o homem se relaciona com seu meio através de um processo interpretativo, deve ser entendido sempre em um perspectiva não teórica, o próprio dasein, não é uma "entidade" para ser tratada na perspectiva teórica. E o que exatamente isso quer dizer? Quer dizer que a relação do homem com as coisas que o cercam é mediada através do processo do seu engajamento em relação a essas coisas.

A função da filosofia é ajudar a entender esse engajamento! 
E o que é exatamente se engajar? Para Heidegger, se engajar é se envolver em tarefas, é o que ele chama de "cuidar". Para entender um pouco melhor esse complicado e perigoso conceito (complicado porque estamos tão acostumados a outras formas encobridoras de ver nossa relação com o mundo que a proposta do Heidegger soa, a princípio, incompreensível), vale a pena um contraponto dessa descrição com quase todas as anteriores que fiz com relação ao humanismo. Para a maioria dessa tradição filosófica, a principal relação do homem com o mundo é a de conhecer esse mundo, para Heidegger, ao contrário, a relação primordial do homem com o mundo, é cuidar desse mundo, não esquecendo, contudo a perspectiva de que cuidar do mundo é também e de forma absolutamente indissociável, cuidar de si. E aqui nos aproximamos verdadeiramente do final, não por que julgue que consegui explicar o que Heidegger define como "cuidado", mas por que é em torno da noção heideggeriana de cuidado que quero apontar novamente para a dimensão humana, no plano filosófico, da medicina. É em torno dessa noção que pretendo continuar em um projeto futuro o desenvolvimento dessa tese.

Cuidar para Heidegger não tem absolutamente o sentido de tomar conta de alguém ou de algo, de zelar. Não é isso. Para ele, cuidar é se engajar nas tarefas (conforme definido na fenomenologia do dasein) de uma determinada forma, e, essa forma tem a ver com: ter objetivos, ter emoções, ter uma certa disposição de ânimo. Há enormes perigos e armadilhas no uso dessas palavras e nessa superficial descrição de cuidado em Heidegger, isso por que, não se trata, em seu pensamento, de fundar uma nova psicologia, de buscar dentro do homem características que o fazem se envolver de uma determinada forma com seus problemas e aspirações. Junto com a destruição do primado da consciência, junto com sua briga contra a tradição filosófica representada por Descartes, Heidegger, elimina também toda possibilidade de se utilizar seu pensamento como uma forma de psicologia. $O$ que ele quer dizer com "cuidado" e com "emoções" (essa última palavra Heidegger não usa nesse formato, tendo eu a usado para conseguir escrever sobre o assunto sem ter que recorrer aos jargões e neologismos próprios dessa filosofia, uma retórica, ainda que fascinante, verdadeiramente hermética e notoriamente difícil), é algo como: nossos objetivos, nossas disposições de ânimo estão ai, como nós 
estamos ai, presentes no mundo, e a forma como as utilizamos, essa forma, modula nossa relação com o mundo. Uma pessoa deprimida vive num mundo depressivo, uma pessoa ambiciosa vive num mundo de ambições. Um médico exclusivamente preso ás regras da Epidemiologia Clínica, trata apenas a ciência que o paciente lhe traz. Esse, em poucas palavras, é o sentido de cuidar em Heidegger. Pensar dessa forma, por incrível que pareça, (e para os céticos remeto diretamente à obra referida do autor), faz com que nossa relação com o mundo se desloque do plano do pensamento filosófico, ou mesmo do pensamento científico, sobre como se conhece o mundo, para o plano pragmático de como se lida com as tarefas que o mundo nos impõe. 0 problema não é saber "sobre", o problema é saber "como". A questão não é entender o que nos motiva a pregar um prego na parede, ou entender com que força ou angulação se deve bater o martelo, mas, usar o prego e a parede como equipamentos indispensáveis para simplesmente efetuar o ato de pregar o prego na parede. Usar o prego, o martelo e a parede. Estar envolvido nessa tarefa, estar engajado nela. O desafio é tentar imaginar uma filosofia dessa linhagem, dessa estirpe, interferindo não num ato banal como o que acabo de descrever a título de exemplo, mas, numa ação complexa e de múltiplas interfaces como é o tratamento de um paciente. A prática médica em todos seus formatos e desdobramentos. O paciente como um instrumento, o médico como um instrumento, ambos como equipamentos de um processo mais complexo e completo. Desafio olímpico que talvez requeira métodos heterodoxos de se pensar e, sobretudo, o uso de palavras incomuns.

Heidegger como já disse, reverteu todo pensamento oriundo da metafísica tradicional. Sua filosofia faz tudo o que escrevi previamente demandar uma nova interpretação. Ele subverteu toda nossa capacidade de entender como devemos nos posicionar para entender o mundo que nos cerca. Há vários outros pontos da fenomenologia do dasein que, propositalmente não descrevi. O que quero chamar a atenção, para definitivamente terminar minha argumentação, é que o pensamento derivado da hermenêutica heideggeriana, pode, a exemplo do que aconteceu com o pensamento de Hume, revelar novas e insuspeitas formas de pensar o homem, de pensar um humanismo, e, finalmente que essas formas podem contribuir para uma proposta de prática 
médica que seja mais humana, ainda que, talvez, para isso, tenhamos que abrir mão da palavra: humano!

No dizer do próprio filósofo em um texto cujo nome remete diretamente à discussão que estou querendo suscitar com essa questão que abri sobre o humanismo em medicina, "Carta sobre o Humanismo" (Heidegger, 2005 a): "O pensar é atento a estas simples relações. Para elas procura ele a palavra adequada no seio da linguagem tradicional da Metafísica. Gramática, que vem de longe. É problemático se um tal pensar - supondo que ainda importa uma expressão como tal - deixa ainda denominar-se humanismo. Certamente que não, enquanto o humanismo já é metafísico".

Avançando um pouco mais no mesmo texto: "Será que se deve chamar a este "humanismo" que fala contra todo o humanismo conhecido, mas que ao mesmo tempo, de maneira alguma se arvora em intérprete do inumano, ainda de "humanismo"? E isto apenas para talvez, participando no uso da expressão, acompanhar as correntes dominantes que se afogam no subjetivismo metafísico e que estão afundadas no esquecimento do ser? Ou será tarefa do pensamento tentar, através de uma aberta oposição contra o "humanismo", um novo impulso que poderia suscitar uma atenção para a humanitas do homo humanus e sua fundamentação? Pois desse modo - caso o momento da história universal atual já não a provocasse por si mesmo - poder-se-ia despertar uma reflexão que pensasse, não apenas sobre o homem, mas sobre a "natureza" do homem, não apenas sobre a natureza, mas ainda mais originalmente sobre a dimensão na qual a essência do homem, determinada a partir do próprio ser, se torna familiar. Não seria melhor suportarmos antes, por mais algum tempo ainda, os inevitáveis mal-entendidos, deixando-os desgastarem-se lentamente; mal-entendidos aos quais o caminho do pensamento está exposto até agora no elemento de Ser e Tempo. Estas falsas interpretações são naturalmente interpretações do que se leu, ou de opiniões de outros que leram e do que se pensa saber já antes da leitura. Todos eles revelam a mesma estrutura e o mesmo fundamento". 
"Porque se fala contra o "humanismo", teme-se uma defesa do inumano e uma glorificação da barbárie brutal. Pois o que há de "mais lógico" do que ficar, para aquele que nega o humanismo, apenas com a afirmação da desumanidade?".

Será que há realmente como pensar a prática médica dessa forma? Praticá-la sob esses fundamentos? Penso que sim. Penso que é possível escapar da racionalidade científica e penetrar em outra forma de pensar, mas, para isso, a simples reflexão não é suficiente. Há que se tentar praticar essa outra racionalidade lidando com pacientes, ouvindo-os, vendo-os, tocando-os, interpretando-os. Colher seus depoimentos, intervir sobre suas inquietações, dúvidas e sofrimentos. Errar e aprimorar uma prática humana. Uma prática médica mais humana.

Esse é um projeto futuro. Um caminho-pedra que terá que ser percorrido. 


\section{Bibliografia}

Adorno TW, Horkheimer M. Dialética do Esclarecimento. Rio de Janeiro, 2006.

Adorno T W. Introdução à Sociologia. São Paulo: Unesp; 2007.

Adorno TW. Minima Moralia. Rio de Janeiro: Beco do Azougue; 2008.

Aristóteles. Del Alma. IN: Obras. Madrid 1982: 83-219.

Aristóteles. Ética Nicomaquea - Ética Eudemiana. IN: Obras. Madrid 1982: 221-647.

Avorn, J. Paying for drug approval - Who's using whom? N Engl J Med. 2007; 356:1697-1700.

Ayres JRCM. Sobre o Risco - para compreender a epidemiologia. São Paulo: HUCITEC; 2002.

Ayres JRCM. Epidemiologia, promoção da saúde e o paradoxo do risco. Rev Bras Epidemiol. 2002;5(1):28-42.

Ayres JRCM. Interpretação histórica e transformação científica: a tarefa hermenêutica de uma teoria crítica da epidemiologia. Revista de Saúde Pública. 1994;28(4):311-9.

Ayres JRCM. O cuidado, os modos de ser (do) humano e as práticas de saúde. Saúde e Sociedade. 2004 Set-Dez;13(3):16-29. 
Ayres JRCM. Para comprender el sentido práctico de las acciones de salud: contribuciones de la Hermenéutica Filosófica. SALUD COLECTIVA. Buenos Aires, 2008 Mayo-Agosto; 4(2):159-172.

Bachelard G. Filosofia do Novo Espírito Científico. Lisboa: Presença; 1976.

Benevides R, et al. A humanização como dimensão pública das políticas de saúde. Ciência e Saúde Coletiva. 2005a;10(3):561-71.

Benevides R, et al. Humanização na saúde: um novo modismo. Comunic Saúde Educ. 2005b Mar-Ago;9(17):389-406.

Bernard B. Afterthoughts. IN:The economics of drug innovation center for study of private entrepreneurship. Study of Private Enterprise. Washington, D.C. 20016 , 1970: 1970:265-287.

Bobbitt, P. A Guerra e a paz na história moderna. Rio de Janeiro: Editora Campus, 2003.

Burns JJ. Modern Drug Research. IN:The economics of drug innovation center for study of private entrepreneurship. Study of Private Enterprise. Washington, D.C. 20016, 1970: 1970:35-62.

Casate JC, et al. Humanização do atendimento em saúde: conhecimento veiculado na literatura brasileira de enfermagem. Rev Latino-Am Enfermagem. 2005 Jan-Fev;13(1):105-11.

Canguilhem G. O Normal e o Patológico. Rio de Janeiro: ForenseUniversitária; 1982.

Canguilhem G. Ideologia e racionalidade nas ciências da vida. Lisboa: Edições 70; 1977. 
Canguilhem G. Escritos sobre a medicina. Rio de Janeiro: ForenseUniversitária; 2005.

Canguilhem G. O que é a Psicologia? Revista Tempo Brasileiro. 1973; (30/31).

Center for Regulatory Effectiveness. The quiet shift of power; [acesso em 12 Dec 2009].Disponível em: http://www.thecre.com/ombpapers/VAJournal.htm

Clymer HA. The Changing Costs and Risks of Pharmaceutical Innovation. IN:The economics of drug innovation center for study of private entrepreneurship. Study of Private Enterprise. Washington, D.C. 20016, 1970::109-24.

Cooper JD. Philosophy and technology of drug assessment, vol. I Decisionmaking on the efficacy and safety of drugs. Washington, D.C.: Smithsoniam Institution;1971.

Cooper JD. Philosophy and technology of drug assessment, vol. II. The quality of advice. Washington, D.C.: Smithsoniam Institution, 1971.

Cooper JD. Philosophy and technology of drug assessment, vol. III. The Philosophy of evidence. Washington, D.C.: Smithsoniam Institution; 1971.

Cooper JD. The source of innovation. IN:The economics of drug innovation center for study of private entrepreneurship. Study of Private Enterprise. Washington, D.C. 20016, 1970: 1970:41-54.

Cooper JD. Introduction. IN:The economics of drug innovation center for study of private entrepreneurship. Study of Private Enterprise. Washington, D.C. 20016, 1970: 1970.

Descartes R. Key philosophical writings. Londres: Wordsworth Editions; 1997. 
Deleuze G. Empirismo e subjetividade. São Paulo: Editora 34, 2001.

Dukes G. The law and ethics in pharmaceutical industry. Amsterdam: Elsevier; 2005.

Dutra LH. A Pragmática de Investigação Científica. São Paulo: Loyola; 2008.

Durkheim E. Lições de Sociologia. São Paulo: Martins Fontes; 2002.

Durkheim E. As Regras do Método Sociológico. São Paulo: Martins Fontes; 2007.

Feinstein AR. Scientific methodology in clinical medicine. I. Introduction, principles and concepts. Ann Intern Med. 1964;61: 564-79.

Feinstein AR. Scientific methodology in clinical medicine. II. Classification of human disease by clinical behavior. Ann Intern Med. 1964;61:757-81.

Feinstein AR. Scientific methodology in clinical medicine. III. Evaluation of therapeutical response. Ann Intern Med. 1964;61:944-72.

Feinstein AR. Scientific methodology in clinical medicine. IV. Acquisition of clinical data. Ann Intern Med. 1964;61:1162-93.

Feinstein AR. Scientific standards in epidemiologic studies of the menace of daily life. Science. 1988;242:1257-63.

Feinstein AR. Scientific news and epidemiology editorials: a reply to critics. Epidemiology. 1990;1(2):170-80.

Feyerabend PK. Diálogos sobre o conhecimento. São Paulo: Perspectiva; 2008. 
Feyerabend PK. Contra o método. São Paulo: Unesp; 2003.

Filho NA. A clínica e a epidemiologia. Salvador: APCE-ABRASCO; 1997.

Foucault M. Estratégia, Poder-Saber. Rio de Janeiro: Forense-Universitária; 2006.

Foucault M. A arqueologia do saber. Rio de Janeiro: Forense-Universitária; 2005 a.

Foucault M. As palavras e as coisas. Lisboa: Portugália; 1966.

Foucault M. Vigiar e Punir. Petrópolis: Vozes; 1975.

Foulcault M. O Nascimento da clínica. Rio de Janeiro: ForenseUniversitária; 2004.

Foulcault M. A verdade e as formas jurídicas. Rio de Janeiro: Nau; 2005b.

Foucault M. Arqueologia das ciências e história dos sistemas de pensamento. Rio de janeiro: Forense-Universitária; 2005c.

Foucault M. Nascimento da biopolítica. São Paulo: Martins Fontes; 2008a.

Foucault M. Em defesa da sociedade. São Paulo: Editora Martins Fontes; 2005d.

Foucault M. Segurança, Território e População: São Paulo: Martins Fontes, 2008b.

Forman HI. Compulsory Licencing, Prices \& Innovation IN:The economics of drug innovation center for study of private entrepreneurship. Study of Private Enterprise. Washington, D.C. 20016, 1970: 177-228. 
Fortes PAC. Ética, direitos dos usuários e políticas de humanização da atenção à saúde. Saúde e Sociedade. 2004 set-dez;13(3):30-5.

Gadamer HG. Verdade e método I. Petrópolis: Vozes; 2004a.

Gadamer HG. Verdade e método II. Petrópolis: Vozes; 2004b.

Gadamer HG. O caráter oculto da saúde. Petrópolis: Vozes; 2006.

Gadamer HG. A Razão na época da ciência. Rio de Janeiro; 1983.

Greenland S. Science versus advocacy: the challenge of Dr. Feinstein. Epidemiology. 1991;2(1):64-72.

Guyatt GH, et al. User's guides to the medical literature A. Are the results of the study valid? JAMA. 1993;270(21):2598-601.

Harvey D. O neoliberalismo. São Paulo: Loyola; 2008.

Hayek FA. The road to serfdom. Chicago: Chicago University Press; 2007.

Habermas J. A Crise de Legitimação do Capitalismo Tardio. Rio de Janeiro: Tempo Brasileiro; 2002.

Habermas J. Teoria de la Acciòn Comunicativa I. Madrid: Taurus; 2003a.

Habermas J. Teoria de la Acciòn Comunicativa II. Madrid: Taurus; 2003b.

Habermas J. Técnica e Ciencia como "Ideología". Lisboa: Edições 70; 2006.

Hegel GWF. A razão na história. São Paulo: Editora São Paulo; 2008.

Heidegger M. Carta sobre o humanismo. São Paulo: Centauro; 2005. 
Heidegger M. Ser e tempo. Petrópolis: Vozes; 2005.

Hume D. Investigação acerca do entendimento humano. São Paulo: Nacional; 1972.

Hume D. Ensaios morais, politicos e literários. Rio de Janeiro: Topbooks; 2004.

Hume D. Tratado da Natureza Humana. São Paulo: Editora Unesp; 2000.

Hutt PB. Investigations and reports respecting FDA regulation of new drugs (Part I) Clin Pharmacol Ther. 1983 a;33(5):537-548.

Hutt PB. Investigations and reports respecting FDA regulation of new drugs (Part II) Clin Pharmacol Ther. 1983 b;33(5):674-87.

International Conference Harmonization (ICH). History and future of $\mathrm{ICH}$ [acesso em 2009 Dec 3]. Disponível em: http://www.ich.org/cache/compo/276-254-1.html

International Conference Harmonization (ICH). ICH-Good Clinical Practice; [acesso em 2009 Dez 3]. Disponível em: http://www.ich.org/LOB/media/MEDIA482.pdf

Jaeschke $R$, et al. User's guides to the medical literature III How to use an article about a diagnosis test $A$. Are the results of the study valid? JAMA. 1994;271(5):389-91.

James W. Pragmatismo: São Paulo: Martin Claret; 2006.

Jaeschke R, et al. User's guides to the medical literature III. How to use an article about a diagnosis test $B$ what are the results and will they help me in caring for my patients? JAMA. 1994;271(9):703-7. 
Jakobson R. Lingüística e Comunicação. São Paulo: Editora Cultrix, 2008.

Junior KRC. Biomedicina, saber \& ciência: Uma abordagem crítica. São Paulo: HUCITEC; 2003.

Kant E. Crítica da razão prática. Lisboa: Edições 70, 1986.

Kant E. Crítica da razão pura. São Paulo: Ícone Editora, 2007.

Kant E. Idéia de uma história universal de um ponto de vista cosmopolita. São Paulo: Martins Fontes, 2003.

Kant E. Textos seletos. Petrópolis: Vozes; 2005.

Keynes JM. Teoria geral do emprego, do juro e da moeda. São Paulo: Editora Atlas, 1982.

Kissinger, H. Diplomacia. Rio de Janeiro: Livraria Francisco Alves Editora; 1999.

Koyré A. Do Mundo Fechado ao Universo Infinito. Rio de Janeiro: Forense Universitária; 1979.

Koyré A. Estudos de História do Pensamento Científico. Rio de Janeiro: Editora Forense Universitária; 1982.

Koyré A. Estudos Galilaicos. Lisboa: Dom Quixote; 1986.

Kuhn TS. A Estrutura das Revoluções Científicas. São Paulo: Perspectiva; 2007.

Kuhn TS. O caminho desde a estrutura. São Paulo: Unesp; 2006. 
Landes, SL. Riqueza e Pobreza das Nações. Rio de Janeiro: Editora Campus, 1998.

Lasagna L. Constraints on the innovation of drugs. IN:The economics of drug innovation center for study of private entrepreneurship. Study of Private Enterprise. Washington, D.C. 20016, 1970: 1970: 229-64.

Laupacis A, et al. User's guides to the medical literature V. How to use an article about prognosis? JAMA. 1994;272(3):234-7.

Lehman,B. International Intellectual Property Institute. The Pharmaceutical industry and patent system, 2003 [acesso em 2009 dec 05].Disponível em: www.earth.columbia.edu/cgsd/documents/lehman.pdf

Machado R. Deleuze, a arte e a filosofia. Rio de Janeiro: Zahar; 2009.

Mankin, N. Introdução à Economia. São Paulo: Cangage Learning Editora, 2005.

Marx K. Contribuição à critica da economia política. São Paulo: Martins Fontes, 2003.

Martin CM. Reliability in product performance in an innovative environmet. IN:The economics of drug innovation center for study of private entrepreneurship. Study of Private Enterprise. Washington, D.C. 20016, 1970: 63-108.

Mill JS. A liberdade e O Utilitarismo. São Paulo: Martins Fontes; 2000.

MINISTÉRIO DA SAÚDE. Secretaria Executiva/ Núcleo Técnico da Política Nacional de Humanização. Política Nacional de Humanização HumanizaSUS: Objetivos do HumanizaSUS trabalhadores do SUS. Brasília, 2004. [Acesso em: 2009 dez. 05]. Disponível em: 
http://portal.saude.gov.br/portal/saude/cidadao/visualizar texto.cfm?idtxt=28 $\underline{291}$

Montaigne, M. Os Ensaios, livro I. São Paulo: Martins Fontes; 2001.

Montaigne, M. Os Ensaios, livro II. São Paulo: Martins Fontes; 2001.

Montaigne, M. Os Ensaios, livro III. São Paulo: Martins Fontes; 2001.

Monteiro, JP. Hume e a Epistemologia. São Paulo: Editora Unesp; 2009.

Mora F. Dicionário de Filosofia, tomo I (A-D). São Paulo: Loyola, 2004

Mora F. Dicionário de Filosofia, tomo IV (Q-Z). São Paulo: Loyola, 2004

Morabia A. The controversial controversy of a passionate controversialist. J Clin Epidemiol. 2002; 55(12): 1207-13.

Morabia A. P.C.A Louis and the birth of clinical epidemiology. J Clin Epidemiol. 1996; 49(12): 1327-33.

Morabia A. On the origin of Hill's causal criteria. Epidemiology. 1991; 2(5): 367-9.

Mund VA. The return of investment of innovative pharma IN:The economics of drug innovation center for study of private entrepreneurship. Study of Private Enterprise. Washington, D.C. 20016, 1970: 1970: 125-76.

Nielsen JR. Handbook of federal drug law. Filadéfia: Lea \& Febiger, 1986.

Oxman AD, et al. User's guides to the medical literature I. How to get started. JAMA.1993;270(17):2093-95. 
Peltzman S. Regulation and the wealth of nations: The connection between government regulation and economic progress. New Perspectives on Political Economy. 2007;3(2):185-204.

Peltzman S. Regulation of pharmaceutical innovation: The 1962 amendments. AEI Evaluative Study No. 15, Washington, D.C.: American Enterprise Institute; 1974.

Platão. Obras completas. Madrid: Aguillar;1981.

President's Advisory Commission on Consumer Protection and Quality in the Health Care Industry [Acesso em 2009 dec 04] Consumer Bill Rights and Reponsability. Disponível em: http://www.hcqualitycommission.gov/cborr/

Repa L. A transformação da Filosofia em Jürgen Habermas: os papeis de reconstrução, interpretação e crítica. São Paulo: Singular; 2008.

Reis AOA, et al. A humanização na saúde como instância libertadora. Saúde e Sociedade. 2004 ;13(3):36-43.

Russel, B. Ensaios Céticos. Porto Alegre: L\&PM Editora, 2008.

Ricouer P. Hermenêutica e Ideologias. Petrópolis: Vozes; 2008.

Sacket, DL; Haynes, RB; Tugwell, P. Clinical Epidemiology: A basic science of clinical medicine. Boston/Toronto: Little, Brown and Company, 1985.

Savitz DA, et al. Scientific standards of criticism: a reaction to "Scientific standards in epidemiologic studies of the menace of daily life", by A.R. Feinstein. Epidemiology.1990;1(1):78-83.

Savitz DA, et al. Response to Feinstein. Epidemiology. 1991;2(1):61-3. 
Shook JR. Os pioneiros do pragmatismo americano. Rio de Janeiro: DP\&A; 2002.

Smith A. Teoria dos sentimentos morais. São Paulo: Martins Fontes; 2002.

Spivak JM. Images of drug industry. IN:The economics of drug innovation center for study of private entrepreneurship. Study of Private Enterprise. Washington, D.C. 20016, 1970: 9-39.

The American Presidency Project. Presidential executive orders [acesso em 2009 dec 03]. Special Message to the Congress on Environmental Quality. Disponível em: http://www.presidency.ucsb.edu/ws/index.php?pid=2757\&st=National+Indus trial+Pollution+Control+Council\&st1=nixon

The Federal Register. Presidential executive orders [acesso em 2009 dec 03]. Executive order 12291 [acesso em 2009 dec 03]. Disponível em: http://www.archives.gov/federal-register/codification/executiveorder/12291.html

The White House. Presitential executive orders [acesso em 2009 dec 03]. Executive order 12866 - Regulatory Planning and Review. Disponível em: http://www.whitehouse.gov/OMB/inforeg/eo12866.pdf

Tournon, A. Montaigne. São Paulo: Discurso Editorial, 2004.

Todorv, T. O Jardim imperfeito. São Paulo: Editora Edusp, 2005.

U.S Departament of Health and Human Services. FDA U.S. Food and Drug Administration. New Hampshire: U.S Departament of Health and Human Services; [atualizada em 2009 Out 07; acesso em 2009 Dez 4]. Section 107 (c) of the Drug Amendments of 1962. Disponível em: http://www.fda.gov/Regulatorylnformation/Legislation/FederalFoodDrugandC osmeticActFDCAct/ucm070880.htm 
U.S Departament of Health and Human Services. FDA U.S. Food and Drug Administration. New Hampshire: U.S Departament of Health and Human Services; [atualizada em 2009 Out 10; acesso em 2009 Dez 2]. Overview on FDA History. Disponível em: www.fda.gov/AboutFDA/WhatWeDo/History/Overviews/default.htm

U.S Departament of Health and Human Services. FDA U.S. Food and Drug Administration. New Hampshire: U.S Departament of Health and Human Services; [atualizada em 2009 Jan 04; acesso em 2009 Dez 3]. CFR - Code of Federal Regulation Title 21. Disponível em: http://www.accessdata.fda.gov/SCRIPTs/cdrh/cfdocs/cfcfr/CFRSearch.cfm

U.S Departament of Health and Human Services. FDA U.S. Food and Drug Administration. New Hampshire: U.S Departament of Health and Human Services; [atualizada em 2009 Mar 03; acesso em 2009 Dez 5]. Drugs. Disponível em: http://www.fda.gov/drugs/default.htm

Veyne P. Como se escreve a história e Foucault revoluciona a História. Brasília: Editora Universidade de Brasília; 1982.

Weber M. A Ética Protestante e o "Espírito" do Capitalismo. São Paulo: Companhia da Letras; 2004.

Weber M. História Geral da Economia. São Paulo: Editora Centauro; 2006 a.

Weber M. A Gênese do Capitalismo Moderno. São Paulo: Ática; 2006 b.

Weber M. A "Objetividade" do Conhecimento nas Ciências Sociais. São Paulo: Ática; 2006 c. 
Weiss NS. Scientific standards in epidemiologic Studies. Epidemiology. 1990;1(1):85-6.

White H. Meta-História a imaginação histórica do século XX. São Paulo: Editora Universidade de São Paulo; 2008. 